Nicola Bilotta and Fabrizio Botti (eds)

\title{
The (Near) Future of Central Bank Digital Currencies
}

Risks and Opportunities for the Global Economy and Society
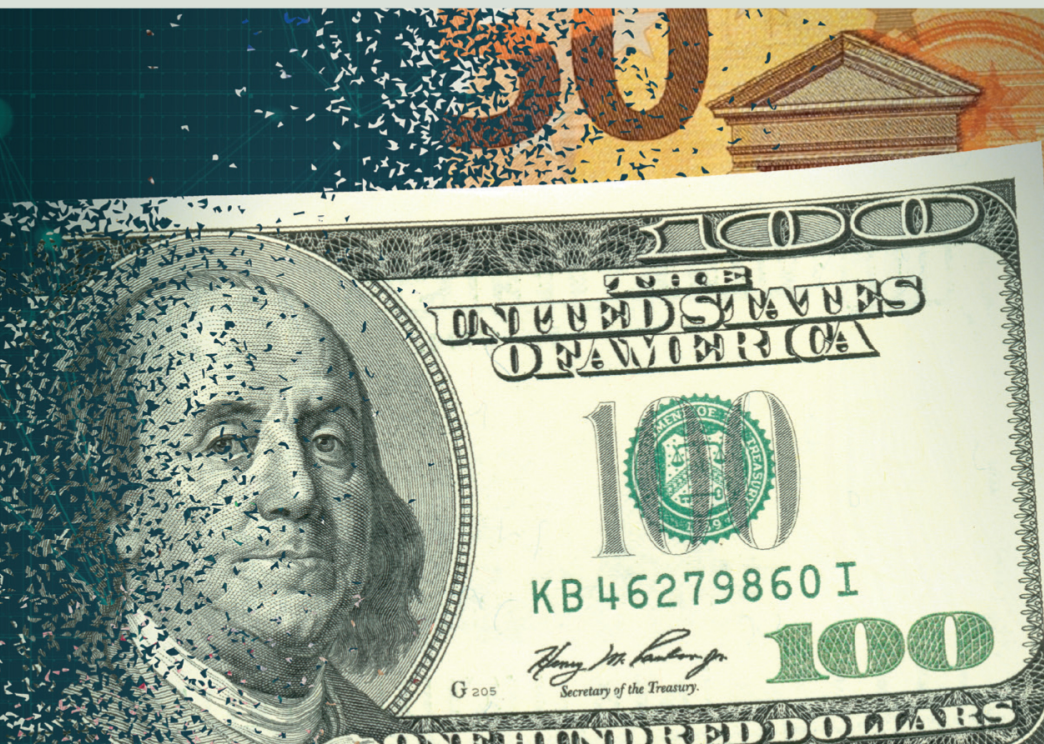

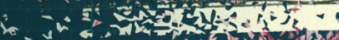


- GLOBAL POLITICS AND SECURITY • Series Editor: Lorenzo Kamel

Nicola Bilotta and Fabrizio Botti (eds)

\section{The (Near) Future of Central Bank Digital Currencies}

The value of global cashless payments has been radically increasing worldwide. Despite cash being the most used payment instrument in the world, technological innovation and new consumer preferences are decisively transforming the way consumers pay and manage money. The COVID-19 pandemic may also have been an accelerator of the cashless mega-trend. Private players currently dominate the digital payment ecosystem, urging central banks to seek solutions to ensure public access to legal tender if cash is phased out. In this context, the idea of a Central Bank Digital Currency (CBDC) is gaining momentum. Nevertheless, there is a need to better understand the implications in terms of risks, benefits and potential costs of CBDCs. From privacy concerns to macroeconomic effects, these implications blur the boundaries of the payment and financial systems, challenging the core functions of our economy and society.

Nicola Bilotta is a researcher at the Istituto Affari Internazionali (IAI) in the international political economy area. Previously, he worked as a senior research analyst at The Banker Research Team (Financial Times), with which he still collaborates. He was associate fellow at the Seven Pillar Institute of Finance \& Ethics and associate researcher at the Istituto di Alti Studi di Geopolitica e Scienze Ausiliari.

Fabrizio Botti is Senior Fellow in the field of economics and finance at Istituto Affari Internazionali (IAI) and Intesa Sanpaolo Fellow. He is also Research Fellow at Guglielmo Marconi University. He is core member of "Minerva - Laboratory on Gender Diversity and Gender Inequality" at the Department of Statistics of Sapienza University of Rome. Previously he was Marie Curie Fellow at the Faculty of Economics and Politics of University of Cambridge and Visiting Fellow at the Centre for African Studies of Florida University. 
The (Near) Future of Central Bank Digital Currencies 


\title{
GLOBAL POLITICS AND SECURITY
}

\author{
Volume 7 \\ Edited by \\ Prof. Lorenzo Kamel, \\ University of Turin's History Department, \\ and Istituto Affari Internazionali (IAI)
}

\section{(6) \\ PETER LANG}

Bern · Berlin · Bruxelles · New York · Oxford 
Nicola Bilotta and Fabrizio Botti (eds)

\section{The (Near) Future of Central Bank Digital Currencies}

\section{Risks and Opportunities for the Global Economy and Society}

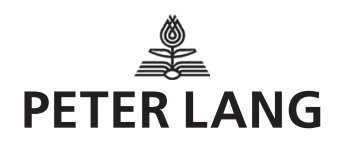


Bibliographic Information published by the Deutsche Nationalbibliothek The Deutsche Nationalbibliothek lists this publication in the Deutsche Nationalbibliografie; detailed bibliographic data is available in the internet at http://dnb.d-nb.de.

\author{
Library of Congress Cataloging-in-Publication Data \\ A CIP catalog record for this book has been applied for \\ at the Library of Congress.
}

This book has been realized thanks to the partnership between IAI and Intesa Sanpaolo and it has been supported by Intesa Sanpaolo and the Bank of Italy.
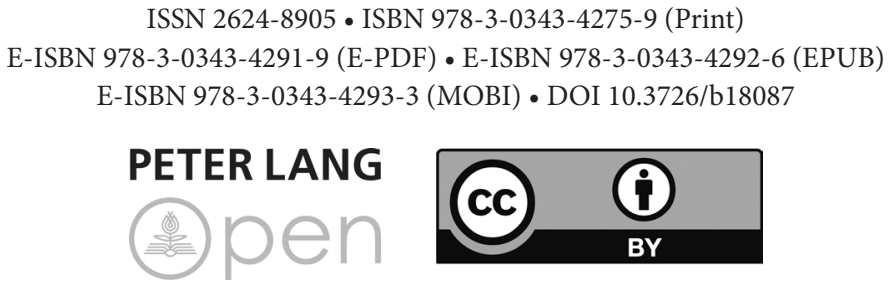

Open Access: This work is licensed under a Creative Commons CC-BY 4.0 license. To view a copy of this license, visit https://creativecommons.org/licenses/by/4.0/

This publication has been peer reviewed.

(C) Nicola Bilotta and Fabrizio Botti, 2021.

Peter Lang AG, International Academic Publishers, Bern

bern@peterlang.com, www.peterlang.com 
The Istituto Affari Internazionali (IAI) has promoted this research effort in partnership with Intesa Sanpaolo and with the support of Intesa Sanpaolo and Bank of Italy. This book would have not seen light of day without the support of the staff at IAI who have been involved in this project in different capacities, in particular Alessandra Bertino, Stefano Scolamiero and Alissa Siara. We are especially grateful to Hugo Doyle, who embraced the idea of this research project and provided insights along the way, together with Alfonso Siano and Federico Orsi, and to all the people and institutions who have contribute and improved this research effort. This list includes Massimo Cirasino, Giuseppe Ferrero, Claude Lopez, Jan Knoerich, Tim Masela, Robleh Ali and Steven L. Schwarcz. In addition, our thanks go to Franco Passacantando, who has been an inviable advisor during the entire journey of this project. Last but not least, our deepest gratitude goes to Lorenzo Kamel and the editorial staff of Peter Lang, who have believed in this project. 



\section{Contents}

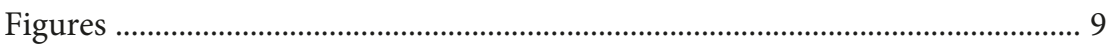

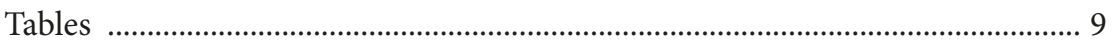

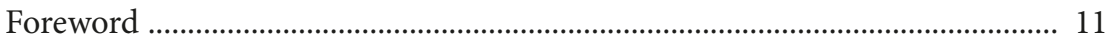

Nicola Bilotta and Fabrizio Botti

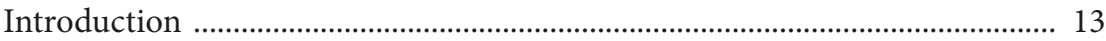

Nicola Bilotta and Fabrizio Botti

Chapter 1: CBDCs: The (Near?) Future of a Cashless Economy .................... 15

Massimo Cirasino

Chapter 2: CBDC in the Broad Context of National Payments System Development

Robleh Ali

Chapter 3: Central Bank Digital Currency and the Future Financial System 75

Steven L. Schwarcz

Chapter 4: Central Bank Digital Currencies and Law 99

Franco Passacantando

Chapter 5: The Digital Euro: Challenges and Opportunities

P.M.T. Masela

Chapter 6: Digital Currency Initiatives on the African Continent

Jan Knoerich

Chapter 7: China’s New Digital Currency: Implications for Renminbi Internationalization and the US Dollar

Nicola Bilotta

Chapter 8: CBDCs and Stablecoins: The Scramble for (Controllable) Anonymity 
Claude Lopez

Chapter 9: Digital Currency: A Global Regulatory Framework is Needed ..... 183

Nicola Bilotta and Fabrizio Botti

Conclusion

Contributors

197

Abbreviations

199 


\section{Figures}

Figure 1.1: Weekly in-store purchases per country in 2019 and 2025 .......... 17

Figure 1.2: The money flower: a taxonomy of money ..................................... 21

Figure 1.3: A taxonomy of money ……………….............................................. 22

Figure 1.4: Money trees .................................................................................. 22

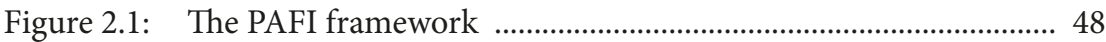

Figure 3.1: Retail payment system structure …………………………….... 77

Figure 3.2: Foreign exchange settlement …………........................................ 78

Figure 3.3: Securities settlement ............................................................. 80

Figure 3.4: Constructing a transaction ……………...................................... 82

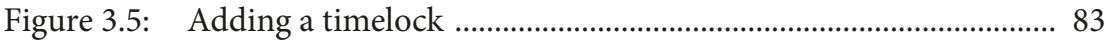

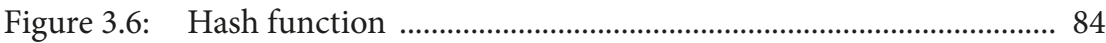

Figure 3.7: Hashlock .................................................................................... 85

Figure 3.8: Payment routing ………………………........................................ 91

Figure 3.9: Switching in payment routing ……................................................ 91

Figure 3.10: PvP using HTLCs ......................................................................... 93

Figure 6.1: Different forms of money ………….......................................... 134

Figure 6.2: $\quad$ CBDC lifecycle …………………............................................ 141

Figure 6.3: CBDC project .......................................................................... 142

\section{Tables}

Table 1.1: Retail CBDC projetcs ................................................................ 31

Table 7.1: Global utilization of the RMB is still comparatively limited .... 156 



\section{Lorenzo Kamel}

\section{Foreword}

Digitalization has been changing the way how people use money, globally reducing the share of cash in transactions in favour of cards and e-money solutions. Despite digital and electronic payment systems having become key payment means, these solutions have not challenged the architecture nor the nature of traditional monetary systems. While decentralized cryptocurrencies have failed in reaching scale, remaining a niche market, the potential development of stablecoins issued by large private corporations could rapidly transform the current monetary systems. In this context of growing digitalization of payments, the discussion around the introduction of a retail central bank digital currency (CBDC) has gained momentum. Theoretically, CBDC could produce great efficiency gains, encourage contestability in payment systems, and foster financial inclusion. Notwithstanding, benefits come together with new risks which need to be addressed by central banks. CBDC's underlying system could be differently designed - such as a two-layer system or one-layer system; token-based or account-based", producing diversified issues and challenges. A set of risks lies in the possible negative effects on the banking industry, like the consequences of potential disintermediation, and in the operational and security challenges for central banks. Moreover, CBDCs raise concerns on the balance of power in society, potentially increasing the ability of governments to look into financial transactions, altering the anonymity that cash gives to citizens. Therefore, the development of CBDCs gives rise to several implications which blur the boundaries of the payment market, potentially transforming the core of the economy and society.

To shed some lights on the potential effects, risks and benefits around the development of CBDCs, the Istituto Affari Internazionali (IAI) has promoted, in partnership with Intesa Sanpaolo and with the support of Intesa Sanpaolo and Bank of Italy, a research effort by putting together a very qualified and diversified group of experts who for more than a year exchanged their views and research on different aspects of this innovation. The result is this book which, I believe, provides readers with an extremely useful tool to get interesting and manifold insights on CBDCs, raising several opened questions to policymakers and regulators. 



\section{Nicola Bilotta and Fabrizio Botti}

\section{Introduction}

Global non-cash transactions reached 708.5 billion transactions in 2019, surged by $80 \%$ since 2014 . Despite cash being the most used payment instrument in the world, technological innovation and new consumer preferences are radically transforming the way consumers pay and manage money. The COVID-19 pandemic may have also been an accelerator in consolidating cashless transactions by driving the growth of e-commerce and mobile/contactless transactions. Private players currently dominate the digital payment ecosystem, urging central banks to seek solutions to ensure public access to legal tender if cash is phased out. In this context, the idea of a central bank digital currency (CBDC) is gaining momentum - a central bank liability, denominated in an existing unit of account, which serves both as a medium of exchange and a store of value. The bulk of central banks surveyed by the Bank for International Settlements ( 80 per cent out of sixty-six central banks), representing 90 per cent of global output, are working on a CBDC. Nevertheless, there is a need to better understand the implications in terms of risks, benefits and potential costs of CBDCs. From privacy concerns to macroeconomic effects, these implications blur the boundaries of the payment and financial systems, challenging the core functions of our economy and society. The key questions are manifold: how will a CBCD affect banking industry models and financial markets? What are the benefits and risks of introducing a CBDC? Which are the different design and technical solutions a $\mathrm{CBDC}$ can offer? What is the play-off between privacy as a democratic freedom and the enforcement of AML rules in the frame of CBDCs?

The Istituto Affari Internazionali (IAI), in partnership with Intesa Sanpaolo and with the support of Intesa Sanpaolo and the Bank of Italy, has carried out a research project to study the main economic and political implications of the development of CBDCs. The result of this analysis - conducted with a group of international experts - are presented in this book. These experts have participated actively in the research throughout the project and their contributions help to shed light on key specific issues and implications related to the development of CBDCs. The first chapter, by Nicola Bilotta and Fabrizio Botti, provides an overview of the approaches, features and implications of CBDCs. It briefly explores the current literature on CBDCs and provides concrete example of this innovation's stage of development. The second chapter, by Massimo Cirasino, analyses in depth the conditions and factors to take into account when launching 
a CBDC. The third chapter, by Ali Robleh, explains how a CBDC system will shape the structure of the whole financial system. Steven Schwarcz's Chapter 4 concentrates on how existing regulations will extend to CBDCs, investigating if this innovation will require further regulation if it is implemented, depending on the design of a CBDC system. The following three chapters take a closer look at geographical areas that are at the frontier in the field of digital currency. The fifth chapter, by Franco Passacantando, analyses the implications of a digital euro, focusing on its potential effects on the functioning of financial markets. The next chapter, by Tim Masela, details the opportunities and risks of CBDCs and digital currencies in Africa. The seventh chapter, by Jan Knoerich, analyses the features and implications of the Digital Currency/Electronic Payments (DCEP), China's CBDC, domestically and internationally. The eighth chapter, by Nicola Bilotta, focuses on the political struggle to find a balance between anonymity and security in CBDCs systems, calling ultimately for multilateralism to ensure the transparency and fairness of CBDCs. The final chapter, by Claude Lopez, looks into the need for a global framework that meets all the challenges produced by the multiplication of private digital currencies and CBDCs.

Initiatives and projects on the developments of CBDCs are rolling out across the world. Any future CBDC system will need to ensure financial stability, competition and resilience, helping central banks to achieve their public policy objectives. The implementation of CBDCs will have a radical impact on the global economy, transforming, at least potentially, the way our society is organised. This book aims at shedding some light on the economic, financial and political implications of the development of CBDCs. 


\section{Nicola Bilotta and Fabrizio Botti}

\section{Chapter 1: CBDCs: The (Near?) Future of a Cashless Economy}

\subsection{Payments are the economy's circulatory system}

'No cash accepted in this store'. What might seem to some like science fiction is actually on its way to becoming reality in some countries. The rise of non-cash payments is a global phenomenon, although moving at different speeds around the world. ${ }^{1}$ Global non-cash transactions reached 708.5 billion transactions in 2019 , surged by $80 \%$ since $2014 .^{2}$ The value of global cashless payments grew from 900 trillion US dollars in 2014 to 1,370 trillion in $2018 .^{3}$ In China and India, for example, the volume of cashless payments increased by 52.6 per cent and 51.4 per cent respectively between 2014 and 2018. In contrast, this figure only grew by an average of 6.95 per cent in the G7 countries. ${ }^{4}$ This gap is due to the fact that in advanced markets, cashless payments have already become ubiquitous. Singapore, South Korea and Sweden led the world in the average number of cashless transactions per inhabitant, in 2018.

Sweden is an intriguing case. The country is predicted, by 2023 , to become the first cashless society (meaning that cash is not extensively accepted as a mean of payment) in the world. Already in 2018, only 13 per cent of retail payments in Sweden were made in cash. ${ }^{5}$ A study shows that when cash transactions make up less than 7 per cent of total transactions, the costs of managing cash exceed the

1 Morten Bech and Codruta Boar, Commentary on Red Book Statistics: Shaping the Future of Payments, November 2019, https://www.bis.org/statistics/payment_stats/commentary1911.htm.

2 'World Payments Report 2020', Capgemini, 01/2021 https://worldpaymentsreport.com/ resources/world-payments-report-2020/.

3 J.PMorgan,J.PMorganPerspectives. Blockchain,DigitalCurrencyandCryptocurrency:Moving Into Mainstream?, 21 February 2020, https://markets.jpmorgan.com/research/open/url/ t59R6MoBP2TUkWA_itSQBbfUlco1CmYnoNL3dA6WVSm82drJuOYLvdZIqDyuXypL4OrVEFw_eAu4UgzicsInqAwjcbKIQHiPfGEjPF2Rt5PKUltFmEKGQaC3DeLBoW7.

4 Excluding Japan.

5 Sveriges Riksbank, The Payment Behaviour of the Swedish Population, updated 20 November 2018, https://www.riksbank.se/en-gb/statistics/statistics-on-paymentsbanknotes-and-coins/payment-patterns. 
marginal profits on cash sales. If this happens, retailers will have no incentive to accept cash payments any longer. ${ }^{6}$

However, a completely cashless society seems unlikely anytime soon. Cash is still persistent in society and remains the most widely used payment instrument in the world. The 2018 G4S report shows demand for cash has actually increased. Globally, average currency in circulation was 9.6 per cent of GDP in 2016, up from 8.1 per cent in 2011. In Europe, 78.8 per cent of all transactions were conducted with cash; the global average was 50 per cent. ${ }^{7}$ People like and trust cash. According to a survey carried out by Deutsche Bank, among the top five reasons why people love cash is that people appreciate that it allows better tracking and spending, while making payments faster. Furthermore, they consider cash convenient and secure. ${ }^{8}$

The availability of non-cash payment instruments has (and will) changed consumer behaviour and how people pay or manage money. In addition to traditional means such as credit or debit cards, smartphones provide consumers with access to digital payment technologies such as e-wallets and e-money. According to the GSMA Mobile Economic Report, the number of unique mobile phone subscribers globally is 5.1 billion, or 67 per cent of the world's population. By 2025, the figure is expected to hit 5.8 billion, of which 5 billion will also be mobile internet subscriptions. These new digital payment solutions are threating both cash and cards transactions. The market for cards in particular is under pressure. As consumer preferences - especially among generation $\mathrm{Z}$ and millennials - are increasingly shifting from cards to emoney and e-wallet solutions, cards issuers risk losing, in the short term, their interface with consumers and, in the long term, the loyalty of consumers. ${ }^{9}$

This trend towards non-cash payment instruments and the preferences for non-card digital payment solutions are globally developing at different paces. In mature markets such as Europe and the United States, for example, people have an entrenched history of using cards, making the shift to digital

6 Jonas Hedman, 'Going Cashless: What Can We Learn from Sweden's Experience?', in Knowledge@Wharton, 31 August 2018, https://knlg.net/2LJhVH3.

7 G4S Cash Solutions, World Cash Report 2018, August 2019, p. 25, https://www. g4scashreport.com.

8 Marion Laboure and Jim Reid, The Future of Payments - Part I. Cash: the Dinosaur Will Survive... For Now, Deutsche Bank Research, 21 January 2020, p. 6, https://www. dbresearch.com/PROD/RPS_EN-PROD/PROD0000000000504353/The_Future_of_ Payments_-_Part_I_Cash:_the_Dinosau.pdf.

9 Zachary Aron, Ulrike Guigui and Megan Scala, 'Getting Ahead of the Curve', in Deloitte Insights, 26 February 2020, https://bit.ly/2WFTLWW. 


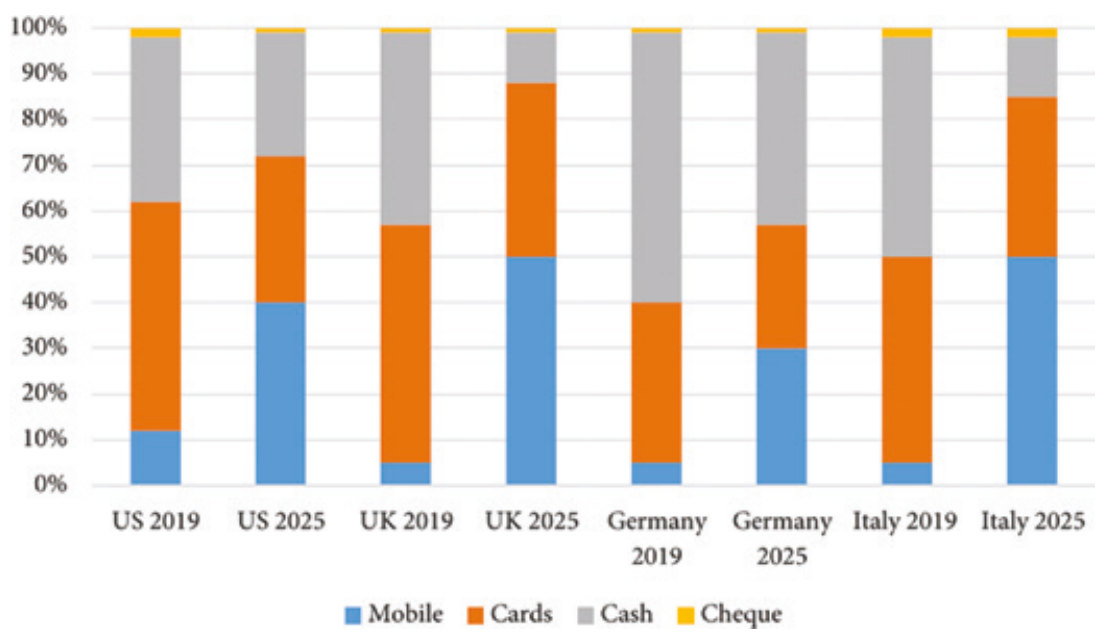

Figure 1.1: Weekly in-store purchases per country in 2019 and 2025.

Source: Marion Laboure and Jim Reid, The Future of Payments - Part II. Moving to Digital Wallets and the Extinction of Plastic Cards, Deutsche Bank Research, 23 January 2020, p. 3, https://www. dbresearch.com/PROD/RPS_EN-PROD/PROD0000000000504508/The_Future_of_Payments_-_ Part_II_Moving_to_Digita.pdf.

payments harder. Analysts however expect to see increasing use of digital payments in these economies because of the preferences of younger generations (see Figure 1.1).

In contrast, in China and India, consumers have switched from cash-based transactions to digital payments, as the latter are more convenient and easier to access than cards. Furthermore, these two countries have a much larger percentage of young people than the EU and the United States. In India, according to KPMG, there are more than 45 mobile wallet providers and 50 providers of wallets based on the Unified Payment Interface or UPI. The increase of cashless transactions has been boosted by the government's decision, implemented in November 2016, to make 86 per cent of the cash in circulation illegal tender. ${ }^{10}$ In China, 49 per cent of the population uses mobile payments, a figure which is

10 Bhaskar Chakravorti, 'One Year After India Killed Off Cash, Here's What Other Countries Should Learn from It', in Harvard Business Review, 2 November 2017, https:// hbr.org/2017/11/one-year-after-india-killed-off-cash-heres-what-other-countriesshould-learn-from-it. 
likely to increase to 60.5 per cent by 2023 . The total transaction value of barcode mobile payments reached 3.23 trillion US dollars in China in 2018, according to iResearch Consulting Group. ${ }^{11}$

In Africa too, digital payments are having a remarkable impact. M-Pesa, a mobile money transfer solution, has more than 37 million users in seven countries (the Democratic Republic of Congo, Egypt, Ghana, Kenya, Lesotho, Mozambique and Tanzania). In Sub-Saharan Africa around 10 per cent of aggregate GDP in transactions occur through mobile money - in Kenya, M-Pesa alone accounted for 50 per cent of the country's GDP in 2018. ${ }^{12}$ In Africa, there are now more mobile payment accounts than bank accounts, the former proving to be an extraordinary instrument for financial inclusion.

The COVID-19 pandemic might accelerate adoption of cashless transaction habits, as there is a general (incorrect) perception that cash can transmit the virus. On 9 March, the World Health Organization released a statement recommending the use of cashless transactions to slow down the spread of COVID-19. According to Google Trends, the number of Internet research of the words 'cash' and 'virus' peaked. A BIS report stressed that this research was more significant in countries where more small-value banknotes are in circulation relative to GDP. ${ }^{13}$ In addition, many countries - such as Austria, the Netherlands, Ireland and the UK - increased the maximum limits for contactless payments with credit or debit cards. This option mitigated the risks of contagion in comparison to payments that require a signature or a PIN input. Similarly, digital wallets like Apple Pay or Google Pay - allow smooth payments without the need to touch any terminal other than the payer's personal mobile device. Furthermore, the sharp jump of online shopping during the lockdowns benefitted the advance of cashless payments.

It is too early to accurately assess whether the COVID-19 pandemic has created a stronger preference for cashless payment solutions in the short- and long-term. However, it has encouraged consumers and businesses to face the new realities of cashless payments, raising awareness of the alternatives to cash. For example, while there has been a fall of 60 per cent in the total value of point-of-sale transactions compared to 2019, the number of contactless

11 'China Is Moving Toward a Cashless Society', in eMarketer, 25 November 2019, https:// www.emarketer.com/content/china-is-moving-toward-a-cashless-society.

12 Amadou N.R. Sy, 'Fintech in Sub-Saharan Africa: A Potential Game Changer', in IMF Blog, 14 February 2019, https://blogs.imf.org/?p=25686.

13 Raphael Auer, Giulio Cornelli and Jon Frost, 'Covid-19, Cash, and the Future of Payments', in BIS Bulletin, No. 3, 3 April 2020, https://www.bis.org/publ/bisbull03.htm. 
transactions in Europe is estimated to have experienced a monthly growth of 4 per cent in March 2020 and an additional weekly increase of 5 per cent in April $2020 .{ }^{14}$ In the United States, the firm Square reported that while only 8 per cent of US sellers identified as cashless on 1 March 2020, by 23 April the figured had increased to 31 per cent. ${ }^{15}$ As e-commerce has rocketed, ACI Worldwide recorded a 74 per cent increase in transaction volumes for online retail and Adyen said that it registered a growth of 30-50 per cent in retail payments during the lockdown. ${ }^{16}$

Technological innovation and new consumer preferences are driving transformations in the way people use money. Financial technology has dramatically changed the payments industry, transforming how consumers access and spend money. However, the nature of money has not changed yet. Aside from the niche market of cryptocurrencies, the other innovative solutions currently available on the market - such as M-Pesa, PayPal or Alipay - only mediate transactions between traditional issuers and holders. Therefore, electronic payments have so far not changed the architecture of the existing model of monetary exchange, which is based on central bank money and deposits in banks. Nevertheless, the landscape of digital transformations could empower the advance of digital currency technology, disrupting both the payment market and the nature of money as we know it.

\subsection{What is money today?}

Technology has the potential to disrupt the functioning of the current architecture of the monetary system, allowing the development of digital forms of money. Our economies have already experienced forms of digital money. People have held digital money balances, banks have offered demand deposits and central banks have issued digital reserves to banks. Technology has provided the monetary architecture with the opportunity to develop and manage a fully digital currency. The most common, but not the only form of recording and sharing

14 Martina Weimert and Arnaud Saiag, COVID-19 and European Retail Payments, Oliver Wyman, June 2020, p. 3, https://www.oliverwyman.com/our-expertise/insights/2020/ jun/covid-19-and-european-retail-payments.html.

15 Alex Gray, 'Cashless Payments Have Spiked During COVID-19, But Don't Expect Paper Money to Disappear', in Fast Company, 10 June 2020, https://www.fastcompany. com/90514952.

16 Stefan Thomalla and Marlene Schnippe, 'How COVID-19 Is Reshaping Retail Payments in Europe', in EY Insights, 17 June 2020, https://go.ey.com/2YN7Sul. 
the distributed ledger, is blockchain technology. The blockchain captures the transaction data of simultaneous transactions in individual blocks, which are then linked in a chronological order, forming a chain of all past transactions. ${ }^{17}$ The disruptive potential of blockchain technology lies in its promise to deliver near-instant transactions at low cost. ${ }^{18}$

Still, the development of digital currencies for retail and wholesale activity would completely change the nature of access to and usage of digital money. Digital currency is a type of currency that has no physical configuration and only exists in digital form. According to the European Central Bank (ECB), virtual currencies are not full forms of money and are defined 'as a digital representation of value, not issued by a central bank, credit institution or e-money institution, which in some circumstances can be used as an alternative to money. ${ }^{19}$ While electronic money (emoney) is described as an electronic store of monetary value on a technical device that may be widely used for making payments to entities other than the e-money issuer' and, depending on the jurisdiction, could be perceived as money in a specific currency. ${ }^{20}$ However, with the development of new types of digital currency, the concepts of e-money or virtual currency have widen.

With these radical changes happening in the monetary architecture, a new taxonomy for all forms of money is required. The BIS (see Figure 1.2) suggests identifying a taxonomy grounded in the interaction of four basic features (accessibility, issuer, form and technology). ${ }^{21}$ Similarly, Claeys (see Figure 1.3) proposes three criteria: (i) who the issuer is: private or public; (ii) what form

17 Trevor I. Kiviat, 'Beyond Bitcoin: Issues in Regulating Blockchain Transactions', in Duke Law Journal, Vol. 65, No. 3, December 2015, p. 569-608, https://scholarship.law.duke. edu/dlj/vol65/iss $3 / 4$.

18 Darrell Duffie, Digital Currencies and Fast Payment Systems: Disruption is Coming, Draft presented to the Asian Monetary Policy Forum, Singapore, 31 May 2019, https:// www.darrellduffie.com/uploads/policy/DuffieDigitalPaymentsMay2019.pdf.

19 European Central Bank (ECB), Virtual Currency Schemes: A Further Analysis, Frankfurt am Main, ECB, February 2015, p. 25, https://www.ecb.europa.eu/pub/pdf/ other/virtualcurrencyschemesen.pdf.

20 ECB website: Electronic Money, https://www.ecb.europa.eu/stats/money_credit_ banking/electronic_money/html/index.en.html.

21 Morten Linnemann Bech and Rodney Garratt, 'Central Bank Cryptocurrencies', in BIS Quarterly Review, September 2017, p. 55-70, https://www.bis.org/publ/qtrpdf/r qt1709f.htm. 


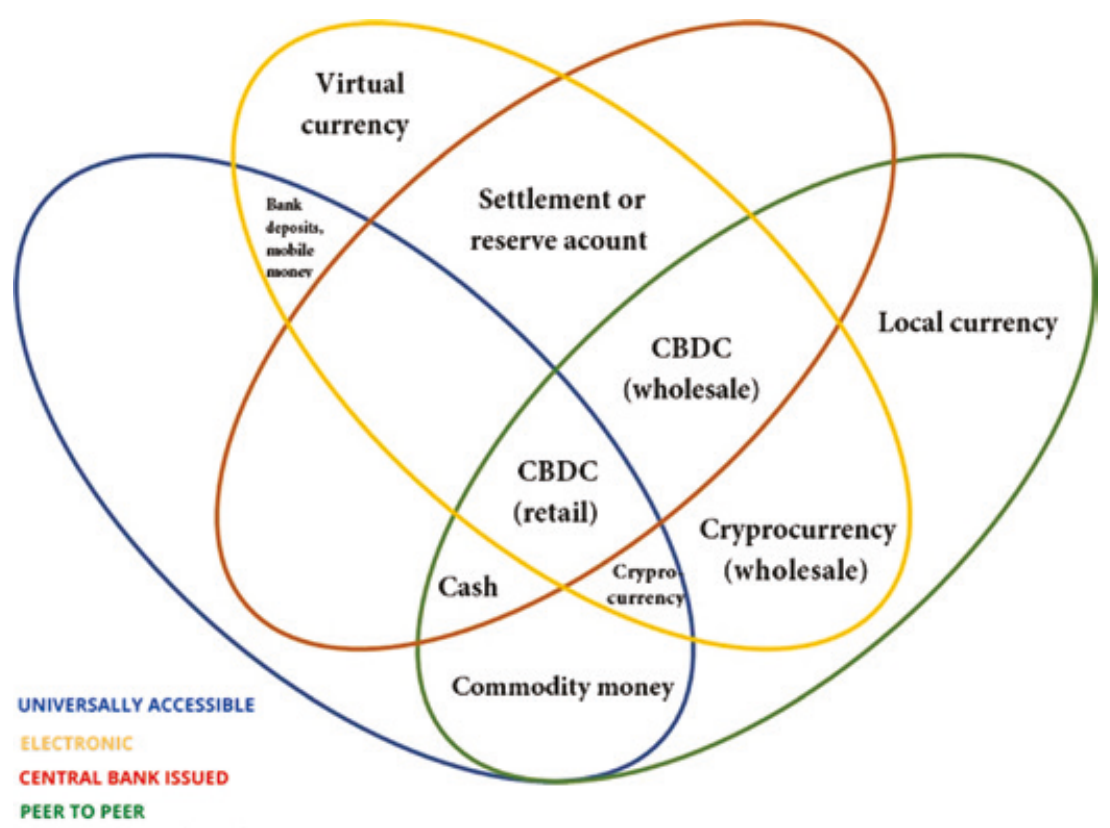

Figure 1.2: The money flower: a taxonomy of money.

Source: Morten Linnemann Bech and Rodney Garratt, 'Central Bank Cryptocurrencies', cit., p. 60.

the transaction takes: digital or physical; and (iii) how transactions are settled: centralised or decentralised. ${ }^{22}$ Adrian and Mancini-Griffoli (see Figure 1.4) have proposed a different framework. The first attribute to be considered is type (a claim or an object), followed by value (either fixed or variable), and technology (centralised or decentralised settlement). There is also a fourth feature, related only to fixed means, which is whether this form of money is privately or publicly backstopped. ${ }^{23}$

22 Grégory Claeys and Maria Demertzis, 'The Next Generation of Digital Currencies: In Search of Stability', in Bruegel Policy Contributions, No. 15, December 2019, https:// www.bruegel.org/? $\mathrm{p}=33489$.

23 Tobias Adrian and Tommaso Mancini Griffoli, 'The Rise of Digital Money', in FinTech Notes, No. 19/01, July 2019, https://www.imf.org/en/Publications/fintech-notes/Issues/ 2019/07/12/The-Rise-of-Digital-Money-47097. 


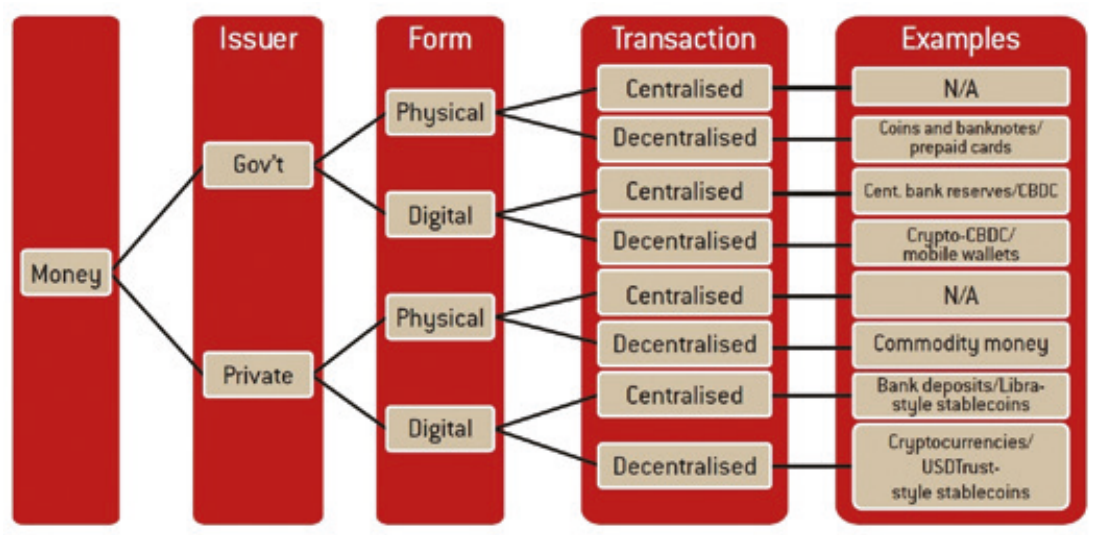

Figure 1.3: A taxonomy of money.

Source: Grégory Claeys and Maria Demertzis, 'The Next Generation of Digital Currencies..., cit., p. 3.
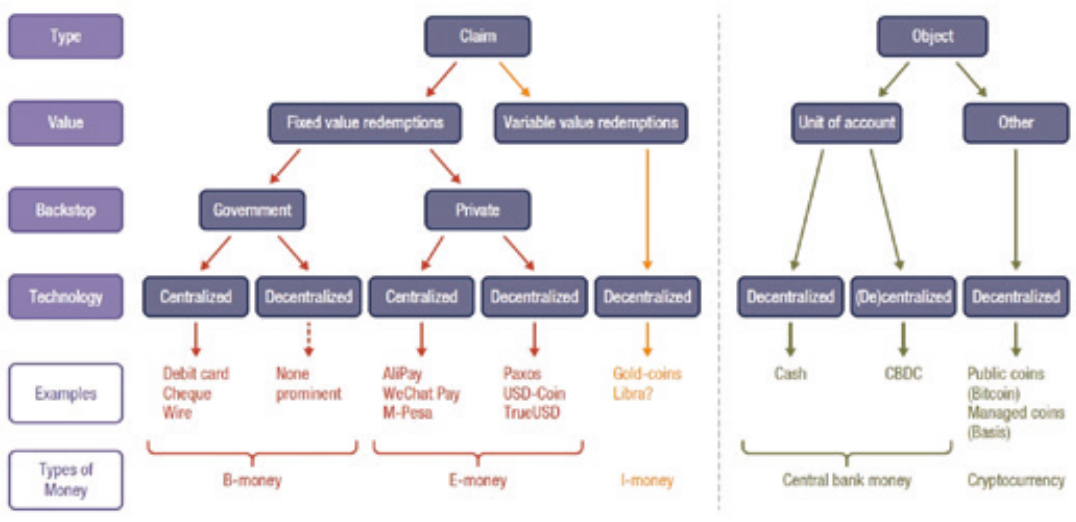

Figure 1.4: Money trees.

Source: Tobias Adrian and Tommaso Mancini Griffoli, 'The Rise of Digital Money', cit., p. 3.

Despite different approaches, what clearly stands out from their analysis is that our society is experiencing a growing landscape of competing means of mediums of exchange.

The question is therefore whether digital currencies are a form of money. Money is traditionally defined as a financial asset which acts as (i) a medium 
of exchange, (ii) store of value and (iii) unit of account. To fulfil these three functions, money needs to have broad acceptance and needs to guarantee the safeguard of its value. Some experts believe that digital currencies barely meet the criteria to be considered full forms of money. ${ }^{24}$

Whether new digital currencies can be considered a full-fledged form of money or not seems to be just a theoretical discussion. Once a digital currency is issued and starts circulating, it can be used as an unbundled form of money by the general public. As previously described, the taxonomy of digital money is a challenging exercise. Due to the nature of money being a 'promise to pay', the support of any digital currency is directly linked to the trust that market participants will accept this type of medium of payment. ${ }^{25}$ Thus, two types of digital currency appear to be the best equipped to potentially reach scale in the coming future: CBDCs and stablecoins backed by large corporations. While the former benefit from being a public form of money supported by the state, the latter seem to provide lower volatility than cryptocurrencies, offering to users a more stable store of value. Furthermore, if backed up and integrated in a pre-established large ecosystem of service, stablecoins might have the features needed to quickly scale up.

But does it really matter if digital currencies are money or if they have the traditional features of a currency? Even if none of the digital currency options become mainstream because they lack all the traditional features of currency, they could easily boost the unbundling of a currency's functions, encouraging consumers to choose currency based on specific needs. ${ }^{26}$ Even if a digital currency becomes popular only as a mean of payment, being too volatile as a store of value, it could still be adopted widely. Also, in a scenario in which cash, fiat money and different kinds of digital currency coexist, the impacts on the monetary system would be ground-breaking, disrupting the historical monopoly of central banks, and producing new risks and effects.

24 Eddie Gerba and Margarita Rubio, 'Virtual Money: How Much do Cryptocurrencies Alter the Fundamental Functions of Money?', in Salomon Fiedler et al., The Future of Money. Compilation of Papers, Luxembourg, European Parliament, December 2019, p. 51, https://op.europa.eu/s/on1P.

25 Central Bank Digital Currencies Working Group (CBDC WG), 'Key Aspects around CentralBankDigitalCurrencies.PolicyReport',in CEMLAReports, May2019,p.11,https:// www.cemla.org/fintech/docs/2019-06-KeyAspectsAroundBankDigitalCurrencies.pdf.

26 Markus K. Brunnermeier and Harold James, 'The Digitalization of Money', in NBER Working Papers, No. 26300, September 2019, https://www.nber.org/papers/w26300. 


\subsection{CBDCs: a digital 'public' currency}

In the current monetary system, central banks' money has a physical form (bills and coins) and a digital form (as reserves held at central banks by financial institutions that can access this deposit facility for wholesale transactions). The introduction of a CBDC would then produce a new form of central bank money, creating a digitalised form of a sovereign currency that would be a liability of central banks. According to the Bank of England, a CBDC can be defined as electronic central bank money that

(i) can be accessed more broadly than reserves, (ii) potentially has much greater functionality for retail transactions than cash, (iii) has a separate operational structure to other forms of central bank money, allowing it to potentially serve a different core purpose, and (iv) can be interest bearing, under realistic assumptions paying a rate that would be different to the rate on reserves. ${ }^{27}$

An extensive body of literature on CBDCs exists, discussing their advantages and disadvantages ${ }^{28}$ systemic implications ${ }^{29}$ how they should be

27 Michael Kumhof and Clare Noone, 'Central Bank Digital Currencies - Design Principles and Balance Sheet Implications', in Bank of England Staff Working Papers, No. 725, May 2018, p. 4, https://www.bankofengland.co.uk/working-paper/2018/ central-bank-digital-currencies---design-principles-and-balance-sheet-implications.

28 Todd Keister and Daniel Sanches, 'Should Central Banks Issue Digital Currency?', in Federal Reserve Bank of Philadelphia Working Papers, No. 19-26, June 2019, https:// doi.org/10.21799/frbp.wp.2019.26; Jinock Kim and Jaejung Kang, 'Money, to Be Publicly Issued, or Not to Be, That Is the Question', in The Journal of Internet Electronic Commerce Resarch, Vol. 19, No. 5, 2019, p. 77-91; Hanna Armelius, Carl Andreas Claussen and Scott Hendry, 'Is Central Bank Currency Fundamental to the Monetary System?', in Sveriges Riksbank Economic Review, No. 2020-2, June 2020, p. 19-32, https://www.riksbank.se/globalassets/media/rapporter/pov/artiklar/engelska/2020/ 200618/2020_2-is-central-bank-currency-fundamental-to-the-monetary-system.pdf; Timothy Jackson and George Pennacchi, 'How Should Governments Create Liquidity?', in University of Liverpool Management School Working Papers, No. 202029, September 2020, https://www.liverpool.ac.uk/media/livacuk/schoolofmanagement/research/economics/How,Should,Governments,Create,Liquidity.pdf.

29 Markus K. Brunnermeier and Dirk Niepelt, 'On the Equivalence of Private and Public Money', in Journal of Monetary Economics, Vol. 106, October 2019, p. 27-41; Jesús Fernández-Villaverde et al., 'Central Bank Digital Currency: Central Banking for All?', in NBER Working Papers, No. 26753, February 2020, https://www.nber.org/ papers/w26753; Ohik Kwon, Seungduck Lee and Jaevin Park, Central Bank Digital Currency, Inflation Tax, and Central Bank Independence, 13 February 2020, http:// dx.doi.org/10.2139/ssrn.3581294; Elena Carletti et al., The Bank Business Model in 
designed; ${ }^{30}$ their role in cross-country payments; ${ }^{31}$ their effects on the international role of currencies; ${ }^{32}$ and laws governing them. ${ }^{33}$

Although CBDCs are not a new idea, the research on developing them has gained momentum in recent years. Some analysts however argue that CBDCs' innovation is not due to their digital nature but due their broad access. ${ }^{34}$ With the growing megatrend of cashless payments dominated by private players, central banks seek to ensure public access to legal tender if cash is phased out, mitigating the consolidation of privately issued money. Furthermore, CBDCs could improve efficiency of the payment industry (see chapter 2 in this volume).

The design of a CBDC directly shapes its functionality and effects in the economy. The first key factor is the degree of access: 'retail CBDC' (also called 'general purpose CBDC') or 'wholesale CBDC'. In a retail CBDC structure, the general public would be allowed to hold and access the CBDC, either by owning

the Post-Covid-19 World, London, Centre for Economic Policy Research, June 2020, https://voxeu.org/node/65851.

30 Itai Agur, Anil Ari and Giovanni Dell'Ariccia, 'Designing Central Bank Digital Currencies', in IMF Working Papers, No 19/252, 2019, https://www.imf.org/en/ Publications/WP/Issues/2019/11/18/Designing-Central-Bank-Digital-Currencies48739; Seyed Mohammadreza Davoodalhosseini and Francisco Rivadeneyra, 'A Policy Framework for E-Money', in Canadian Public Policy, Vol. 46, No. 1, March 2020, p. 94-106, https://doi.org/10.3138/cpp.2019-010; Sarah Allen et al., 'Design Choices for Central Bank Digital Currency: Policy and Technical Considerations', in NBER Working Papers, No 27634, August 2020, https://doi.org/10.3386/w27634.

31 Udo Milkau, 'International Payments: Current Alternatives and Their Drivers', in Journal of Payments Strategy \& Systems, Vol. 13, No, 3, Fall 2019, p. 201-216.

32 Massimo Ferrari, Arnaud Mehl and Livio Stracca, 'Central Bank Digital Currency in an Open Economy', in CEPR Discussion Papers, No. 15335, October 2020, https://cepr. org/active/publications/discussion_papers/dp.php?dpno=15335.

33 Hossein Nabilou, Central Bank Digital Currencies: Preliminary Legal Observations, 6 February 2019, https://dx.doi.org/10.2139/ssrn.3329993; Simon Hess, Regulating Central Bank Digital Currencies: Towards a Conceptual Framework, 11 August 2020, https://dx.doi.org/10.2139/ssrn.3582501; Juan J. Duque, 'State Involvement in Cryptocurrencies. A Potential World Money?', in The Japanese Political Economy, Vol. 46, No. 1, 2020, p. 65-82; Ansgar Belke and Edoardo Beretta, 'From Cash to Central Bank Digital Currencies and Cryptocurrencies: A Balancing Act Between Modernity and Monetary Stability', in Journal of Economic Studies, Vol. 47, No. 4, 2020, p. 911-938.

34 Dirk Niepelt, 'Digital Money and Central Bank Digital Currency: An Executive Summary for Policymakers', in VoxEU, 3 February 2020, https://voxeu.org/node/ 65037; or 'Reserves for Everyone - Towards a New Monetary Regime?', in VoxEU, 21 January 2015, https://voxeu.org/node/58510. 
an account at the central bank or through third-party mediums such as prepaid cards or e-wallets on mobile devices. Wholesale CBDCs, however, can be accessed only by specific economic actors for interbank payments and securities transactions. This might not be disruptive as, in an efficient economy, domestic banks can already make transactions between each other using reserves held in the national central bank, allowing fast transactions using the real-time gross settlement (RTGS) system. ${ }^{35}$ It would be a different story if a wholesale CBDC system were to support cross-border transactions, allowing foreign institutions to hold and transact in the CBDC. This architecture could therefore improve the current infrastructure of cross-border interbank payments, reducing time and costs of transactions. The current system seems to be somewhat inefficient, because many domestic banks do not hold accounts in foreign central banks, requiring the latter to process cross-border transactions through other networks or foreign partners. Similarly, retail CBDCs could bring the benefit of efficiency in retail cross-border payments. In this case, central banks would need to allow foreign entities to own liquidity in the CBDC. ${ }^{36}$

The next design decision lies in whether a CBDC should be toked-based or account-based. In a token-based system, a CBDC is built with a specific denomination of a token, and the control over a transaction occurs in verifying the authenticity of the token, which is similar to how cash transactions work. An account-based system requires central banks to hold accounts, manage credit/ debit transactions and verify the identities of the two parties involved in the process, as with credit card transactions. ${ }^{37}$ In addition to introducing two different models of governance, these two options produce different macroeconomic and political risks and benefits. For example, central banks could have trouble paying interest on token-based CBDCs, as interests could affect the value of the tokens themselves, (its value will increase when interest payments occur). Meanwhile, an account-based system cannot guarantee fully anonymous transactions and would require central banks to manage a large number of retail

35 Committee on Payments and Market Infrastructures, 'Central Bank Digital Currencies', in CPMI Papers, No 174, 12 March 2018, p. 7, https://www.bis.org/cpmi/publ/d174. htm.

36 Ashley Lannquist et al., 'Central Bank Digital Currency Policy-Maker Toolkit', in World Economic Forum Insight Reports, January 2020, https://www.weforum.org/whitepapers/ central-bank-digital-currency-policy-maker-toolkit.

37 Matthieu Bouchaud et al., Central Banks and the Future of Digital Money, ConsenSys White Paper, January 2010, p. 17, https://cdn2.hubspot.net/hubfs/4795067/ConsenSysCBDC-White-Paper.pdf. 
and corporate accounts, increasing the risk of disintermediation of incumbent financial institutions. Some central banks have also proposed a hybrid system in which token-based CBDCs are integrated in a closed architecture of certified accounts, in the attempt to maximise the benefits of the two systems while mitigating the negative effects.

Moreover, central banks can decide whether to issue a CBDC as a new liability backed by other assets or bonds (thereby expanding their balance sheets) or to replace existing liabilities - cash or reserves - with a CBDC. Technical questions also exist over the underlying technology that would be best suited to support a CBDC system. A BIS report stresses that the implementation of distributed ledger technology (DLT) in case of a wholesale CBDC might not produce significant gains in terms of efficiency and costs compared to the current infrastructure..$^{38}$ Niepelt argued that CBDCs could also be stored in accounts, prepaid cards or on decentralised database structures. ${ }^{39} \mathrm{~A}$ recent paper published by the Bank of Canada highlights that a conventional centralised system could support a CBDC, incorporating some properties of a blockchain, such as immutable data or smart contracts. ${ }^{40}$ Other analysts instead argue that a blockchain system would assure greater transparency, resilience and continuous functionality than a centralised system. ${ }^{41}$ Nevertheless, the choice of technology implemented is crucial, as it has wider implications for the effect of the CBDC on the economy, particularly whether the central bank is seeking a decentralised or centralised verification process.

A final critical issue is how to structure the distribution channel of CDBCs. Central banks can either directly distribute it or delegate it to specific intermediaries - most likely financial institutions. The former scenario would produce high disintermediation, giving central banks much more relevance and power. Further concerns exist on the effects on credit provision if incumbent banks lose access to demand deposits. On the other hand, the second scenario would reduce the effectiveness and accuracy of the central bank's monetary policies.

38 Committee on Payments and Market Infrastructures, 'Central Bank Digital Currencies', cit., p. 1.

39 Dirk Niepelt, 'Digital Money and Central Bank Digital Currency..., cit.

40 Dinesh Shah et al., 'Technology Approach for a CBDC', in Bank of Canada Staff Analytical Notes, No. 2020-6, February 2020, https://www.bankofcanada.ca/?p=209522.

41 Ashley Lannquist et al., 'Central Bank Digital Currency Policy-Maker Toolkit', cit., p. 10. 
A survey carried out by BIS in January 2020, involving 66 six central banks representative of 90 per cent of global output, shows that 80 per cent of the respondents are currently (or will soon be) working on a CBDC, up from 65 per cent in 2017. The countries that are not yet engaging are either very small or have more urgent priorities. Most central banks (around 50 per cent) are focusing on both general purpose and wholesale CBDCs. About 40 per cent of the respondents said they have advanced from conceptual research to experiments or proof-of-concept. However, only 10 per cent have run pilot projects so far. Furthermore, 70 per cent of the respondents reported that it is unlikely or very unlikely that they will issue any CBDC in the short term, while 10 per cent reported they are ready to do so and 20 per cent said they are considering implementation in the medium term. ${ }^{42}$

Countries which are at a more mature stage of CDBC development are Uruguay, Bahamas and Sweden. Interestingly, these countries have different socio-economic structures and, consequently, different motivations to develop a CBDC. The Banco Central de Uruguay (BCU) experimented with a CBDC called e-Peso in a pilot programme from November 2017 to November 2018. Since 2011, the country has undertaken a broad financial inclusion programme. As part of this effort, the government promoted a massive growth of cash dispensing mechanisms and increased ATM presence. Yet, the volume of cash in circulation and ATM withdrawals were steadily falling, encouraging the BCU to test a CBDC to further intensify its financial inclusion campaign. ${ }^{43}$ The BCU released in circulation 20 million e-Pesos in the form of unique digital banknotes of different denominations through a 'e-note manager platform' whose function was to register and verify the ownership of the digital banknotes. Of the total amount, 7 million e-Pesos were distributed by RedPagos - a third-party payment service provider - that was holding an equivalent value of pesos in an account at the central bank. Users could cash-in and cash-out through the RedPagos network. Retail and corporate users' wallets could hold a maximum of 30,000 e-Pesos (around 1,000 US dollars) and 200,000 e-Pesos (around 6,600

42 Codruta Boar, Henry Holden and Amber Wadsworth, 'Impending Arrival - A Sequel to the Survey on Central Bank Digital Currency', in BIS Papers, No 107, January 2020, p. 12-13, https://www.bis.org/publ/bppdf/bispap107.htm; Christian Barontini and Henry Holden, 'Proceeding with Caution - A Survey on Central Bank Digital Currency', in BIS Papers, No 101, January 2019, https://www.bis.org/publ/bppdf/bispap101.htm.

43 Gerardo Licandro, Uruguayan e-Peso on the Context of Financial Inclusion, Presentation for the conference on 'Economics of Payments IX', Basel, 15-16 November 2018, https://www.bis.org/events/eopix_1810/licandro_pres.pdf. 
US dollars) respectively. Users could transfer e-Pesos via mobile phones through text message or via the ad-hoc app, allowing both mobile data-based and offline functions. The infrastructure supporting the e-Peso did not use DLT. ${ }^{44}$ The experiment was considered a success and the BCU is currently evaluating the results to better understand the risks and plan future steps.

In December 2019, the Central Bank of the Bahamas launched the pilot phase of Project Sand dollar, a digital Bahamian dollar, in Exuma in December 2019, which has been extended to Abaco in the first half of 2020. As with Uruguay, the central bank's motivation for the experiment was to increase financial inclusion, improving the domestic payment market. In this case, the experiment seems to have been on a much larger scale. ${ }^{45}$ The sand dollar is a general purpose CBDC that will be available offline as well as through mobile data in the form of tokens. To avoid the risks of producing dramatic disintermediation effects, the central bank planned to set a limit on the amount of the currency that retail and corporate users could hold. Retail users have been allowed a maximum holding capacity of 500 Caribbean dollars and of 1,500 US dollars in monthly transactions, either as payments or receipts. For individual accounts which accepted to undergone a tighter due-diligence, the limits were to be 5,000 US dollars holding capacity and 10,000 US dollars in monthly transactions (and a cap of 100,000 US dollars in transactions per year). In case of corporate users, the limits are to be 8,000 US dollars (or 1/20th of their annual sales receipts) and up to 1 million US dollars per year holding capacity, and $1 / 8$ the of annual sales or 20,000 US dollars per year in transactions. ${ }^{46}$

In addition, for high-value transactions, digital wallets will have to be linked to deposit accounts at domestic financial institutions, so in case there is any excess currency, it can be directed to bank deposits. Finally, the CBDC will not pay interests on deposits. ${ }^{47}$ Furthermore, incumbent financial institutions will maintain a primary role. The Bahamian central bank will not provide consumers with front-end customer service, leaving it to incumbents to offer digital wallets and accounts. The central bank however forecasts that in the medium term it will build up a centralised $\mathrm{KYC} /$ identity register to also allow users without a banking profile to supply data to the register. Incumbent financial institutions are then expected to conduct due diligence on users and transactions.

44 Christian Barontini and Henry Holden, 'Proceeding with Caution..., cit., p. 5.

45 Central Bank of the Bahamas, Project Sand Dollar: A Bahamas Payments System Modernisation Initiative, 24 December 2019, https://www.centralbankbahamas. $\mathrm{com} /$ publications/main-publications/project-sanddollar-a-bahamian-paymentssystem-modernization-initiative.

46 Ibid., p. 14.

47 Ibid., p. 12. 
The Bahamian central bank selected the tech start-up NZIA to build the back end of the infrastructure that supports the CBDC system, leaving the frontend opened to allow third parties to develop services and products around the CBDC. ${ }^{48}$ Despite the lack of specific details on the proposed core infrastructure, the NZIA's website mentioned that the system 'meshes blockchain based payment systems and cutting edge communication network technologies [...] Our system is designed to work with existing financial systems.'49

Driven by different factors, Sweden is also at an advanced stage of experimenting with a domestic CBDC. In the country, the cash use has dramatically fallen, increasing the costs of accepting cash, which could ultimately lead to a scenario in which cash will no longer accepted. Since early 2017, the Swedish central bank (Riksbank) has been working on a CBDC, the e-Krona project, that is still in the first phase of technical investigation. According to the information publicly available, the e-Krona will be token-based and will distributed by thirdparty payment service providers. However, the underlying infrastructure that will support the CBDC has not yet been explained. Riksbank acknowledges that the current stage of DLT development is too immature but it could potentially be a useful tool in the future. ${ }^{50}$

Finally, it is also important to mention an experiment of cross-border and cross-currency payment CBDC, which is taking place between Canada and Singapore. The central banks of the two countries have linked their domestic CBDC experiments -Project Jasper and Project Ubin respectively - which have been developed on two different DLT platforms. ${ }^{51}$ Cross-border CDBC experiments are important tools to envisioning how an international monetary system based on CBDCs could be shaped.

48 Neil Hartnell, 'Provider for Digital B\$ "Will Not Be Greedy"', in The Tribune, 31 May 2019, http://www.tribune242.com/news/2019/may/31/provider-digital-b-willnot-be-greedy.

49 NZIA website: NZIA Limited Identified as Preferred Technology Solutions Provider by the Central Bank of The Bahamas for Digital Currency Project, https://nzia.io/pr/ central-bank-of-the-bahamas.

50 Sveriges Riksbank, The Riksbank's E-Krona Project Report 1, September 2017, https://www.riksbank.se/en-gb/payments--cash/e-krona/e-krona-reports/ekrona-project-report-1; and The Riksbank's E-Krona Project Report 2, October 2018, https://www.riksbank.se/en-gb/payments--cash/e-krona/e-krona-reports/ e-krona-project-report-2.

51 Kevin Helms, 'Central Banks Worldwide Testing Their Own Digital Currencies', in Regulation Bitcoin News, 15 August 2019, https://news.bitcoin.com/?p=328914. 
Table 1.1: Retail CBDC projetcs. I think I would prefer if the table would be horitonzally designed in line with the main text

\begin{tabular}{|c|c|c|c|c|c|}
\hline \multicolumn{4}{|c|}{ Design choices } & \multirow{2}{*}{$\begin{array}{l}\text { Project/ } \\
\text { Country }\end{array}$} & \multirow[t]{2}{*}{ Notes on status, motivation and conclusion } \\
\hline 苞 & 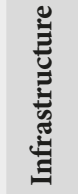 & 总 & 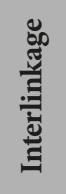 & & \\
\hline D & $\mathrm{U}$ & A & $\mathrm{N}$ & $\begin{array}{l}\text { Rafkróna } \\
\text { Iceland }\end{array}$ & $\begin{array}{l}\text { Research; Aim to address 'steadily diminishing } \\
\text { use of banknotes and coin'; 'many issues have } \\
\text { yet to be clarified, and they must be dealt with } \\
\text { appropriately before a position can be taken. }\end{array}$ \\
\hline $\mathrm{D}$ & $\mathrm{U}$ & A & $\mathrm{N}$ & $\begin{array}{l}\text { Sand Dollar } \\
\text { The Bahamas }\end{array}$ & $\begin{array}{l}\text { Pilot; Improve 'financial inclusion [...], [reduce] } \\
\text { the size of legitimate but unrecorded economic } \\
\text { activities, [strengthen] national defences against } \\
\text { money laundering and other illicit ends [and } \\
\text {...] deliver government services through digital } \\
\text { channels, thereby improving tax administration } \\
\text { and increasing the efficiency of spending. }\end{array}$ \\
\hline $\mathrm{D}$ & $\mathrm{U}$ & $\mathrm{U}$ & $\mathrm{N}$ & $\begin{array}{l}\text { E-krone* }^{*} \\
\text { Denmark }\end{array}$ & $\begin{array}{l}\text { Research; 'the potential benefits of } \\
\text { introducing CBDC are not assessed to } \\
\text { match the considerable challenges that the } \\
\text { introduction would present'. }\end{array}$ \\
\hline D & $\mathrm{U}$ & $\mathrm{U}$ & $\mathrm{N}$ & $\begin{array}{l}\text { E-krone* } \\
\text { Norway }\end{array}$ & $\begin{array}{l}\text { Working group; focus on 'independent back- } \\
\text { up solution, credit riskfree alternative to bank } \\
\text { deposits, competition, legal tender'; 'more } \\
\text { information is required before a conclusion } \\
\text { can be reached' }\end{array}$ \\
\hline H or I & $\mathrm{C}$ & A & I & $\begin{array}{l}\text { E-euro* } \\
\text { The } \\
\text { Netherlands }\end{array}$ & $\begin{array}{l}\text { Research; 'The introduction of CBDC does } \\
\text { not require the use of DLT:; 'opting for CBDC } \\
\text { implies trust in the central bank, which is } \\
\text { why we have chosen a reference design with } \\
\text { a centralised consensus mechanism.; 'the } \\
\text { technology behind account-based digital } \\
\text { payment systems has proven itself to a far } \\
\text { greater extent than value-based digital money'. }\end{array}$ \\
\hline $\mathrm{H}$ or I & $\mathrm{D} \& \mathrm{C}$ & A & $\mathrm{N}$ & $\begin{array}{l}\text { DC/EP } \\
\text { (Digital } \\
\text { currency/ } \\
\text { Electronic } \\
\text { payments) } \\
\text { China }\end{array}$ & $\begin{array}{l}\text { Ongoing work; aim to create digital alternative } \\
\text { to cash and coins for retail use. }\end{array}$ \\
\hline
\end{tabular}


Table 1.1: Continued

\begin{tabular}{|c|c|c|c|c|c|}
\hline \multicolumn{4}{|c|}{ Design choices } & \multirow{2}{*}{$\begin{array}{l}\text { Project/ } \\
\text { Country } \\
\text { E-euro } \\
\text { ECB }\end{array}$} & \multirow{2}{*}{$\begin{array}{l}\text { Notes on status, motivation and conclusion } \\
\text { Research: 'CBDC with the status of legal tender } \\
\text { could guarantee that all users have, in principle, } \\
\text { access to a cheap and easy means of payment'; } \\
\text { 'proof of concept also highlights a number of } \\
\text { areas where there is room for improvement.' }\end{array}$} \\
\hline $\mathrm{H}$ or I & $\mathrm{D}$ & $\mathrm{A} / \mathrm{T}$ & I & & \\
\hline H or I I & $\mathrm{D} \& \mathrm{C}$ & $\mathrm{A} / \mathrm{T}$ & $\mathrm{N}$ & $\begin{array}{l}\text { E-dollar* } \\
\text { Canada }\end{array}$ & $\begin{array}{l}\text { Contingency plan; 'building, as a contingency, } \\
\text { the capability to issue a cash-like central bank } \\
\text { digital currency (CBDC) to the public, should } \\
\text { the need ever arise. }\end{array}$ \\
\hline $\mathrm{H}$ or I & D & $\mathrm{A} / \mathrm{T}$ & $\mathrm{N}$ & $\begin{array}{l}\text { E-krona } \\
\text { Sweden }\end{array}$ & $\begin{array}{l}\text { Pilot; 'within a few years, if the current trend } \\
\text { continues, we will find ourselves in a situation } \\
\text { where cash is no longer generally accepted as a } \\
\text { means of payment'; 'an account-based e-krona } \\
\text { could rationalise payments from agencies and } \\
\text { make them less dependent on commercial } \\
\text { agents' }\end{array}$ \\
\hline $\mathrm{H}$ or I & $\mathrm{D}$ & $\mathrm{T}$ & $\mathrm{N}$ & $\begin{array}{l}\text { Digital Fiat } \\
\text { Currency } \\
\text { Brazil }\end{array}$ & $\begin{array}{l}\text { Research; 'Improve the efficiency of the } \\
\text { monetary function, [...] payment processes } \\
\text { and systems, [...]. financial inclusion and [...] } \\
\text { user experience. Architecture: Hybrid, as on the } \\
\text { one side 'any relationship between the Central } \\
\text { Bank and society is intermediated by financial } \\
\text { institutions, just Rise of the CBDCs: drivers, } \\
\text { approaches and technologies } 40 \text { as with physical } \\
\text { cash. On the other side intermediaries are only } \\
\text { 'custodian of the new cash form' }\end{array}$ \\
\hline H or I & $\mathrm{U}$ & $\mathrm{U}$ & $\mathrm{U}$ & $\begin{array}{l}\text { E-pound }{ }^{\star} \\
\text { United } \\
\text { Kingdom }\end{array}$ & $\begin{array}{l}\text { Research; 'households and businesses should } \\
\text { be able to make fast, efficient and reliable } \\
\text { payments, and benefit from a resilient, inclusive, } \\
\text { innovative, and competitive payment system.; } \\
\text { 'two key elements of the platform: (1) a core } \\
\text { ledger, provided by the Bank, would record } \\
\text { CBDC and process payments, and (2) private } \\
\text { sector 'Payment Interface Providers' would } \\
\text { handle the interaction with end users of CBDC } \\
\text { and provide additional payments functionality } \\
\text { through overlay services' }\end{array}$ \\
\hline
\end{tabular}


Table 1.1: Continued

\begin{tabular}{|c|c|c|c|c|c|}
\hline \multicolumn{4}{|c|}{ Design choices } & \multirow{2}{*}{$\begin{array}{l}\text { Project/ } \\
\text { Country } \\
\text { DXCD } \\
\text { Eastern } \\
\text { Caribbean }\end{array}$} & \multirow{2}{*}{$\begin{array}{l}\text { Notes on status, motivation and conclusion } \\
\text { Pilot; Aim to address the 'high cost of current } \\
\text { payment instruments and banking services', } \\
\text { needs of customers and inefficient cheque } \\
\text { settlement. }\end{array}$} \\
\hline $\mathrm{U}$ & $\mathrm{D}$ & $\mathrm{T}$ & I & & \\
\hline $\mathrm{U}$ & $\mathrm{C}$ & A & $\mathrm{N}$ & $\begin{array}{l}\text { Dinero } \\
\text { Electrónico } \\
\text { Ecuador }\end{array}$ & $\begin{array}{l}\text { Pilot; 'means of payment available to } \\
\text { absolutely all Ecuadorians. Operated 2014-16; } \\
\text { discontinued. }\end{array}$ \\
\hline $\mathrm{U}$ & $\mathrm{D}$ & $\bar{U}$ & $\mathrm{~N}$ & $\begin{array}{l}\text { Bakong } \\
\text { Cambodia }\end{array}$ & $\begin{array}{l}\text { Pilot; aim to 'increase access to quality formal } \\
\text { financial services'; 'decrease demand for [...] } \\
\text { cash'. }\end{array}$ \\
\hline $\mathrm{U}$ & $\mathrm{D}$ & $\mathrm{U}$ & $\mathrm{N}$ & $\begin{array}{l}\text { E-hryvnia } \\
\text { Ukraine }\end{array}$ & $\begin{array}{l}\text { Pilot; Test DLT 'as a technological framework } \\
\text { for e-hryvnia issuance and circulation'; no } \\
\text { fundamental advantage in using DLT in a } \\
\text { centralised model. }\end{array}$ \\
\hline $\mathrm{U}$ & $\mathrm{U}$ & $\mathrm{T}$ & $\mathrm{N}$ & $\begin{array}{l}\text { Electronic } \\
\text { legal tender } \\
\text { South Africa }\end{array}$ & $\begin{array}{l}\text { Expression of interest; 'The scope of this project } \\
\text { is specific to the use of a CBDC as electronic legal } \\
\text { tender (ELT), similar to the characteristics of, and } \\
\text { complementary to, cash. }\end{array}$ \\
\hline$\overline{\mathrm{U}}$ & $\mathrm{U}$ & $\mathrm{U}$ & I & $\begin{array}{l}\text { E-euro* } \\
\text { France }\end{array}$ & $\begin{array}{l}\text { Research; 'account based model would offer } \\
\text { better results for a retail CBDC. However, it } \\
\text { might also lead to a greater loss of resources for } \\
\text { banks. }\end{array}$ \\
\hline $\mathrm{U}$ & $\mathrm{U}$ & $\bar{U}$ & I & $\begin{array}{l}\text { E-euro* } \\
\text { Spain }\end{array}$ & $\begin{array}{l}\text { Research; 'The case of non-anonymous CBDC } \\
\text { based on technology similar to the current } \\
\text { electronic payment methods would imply } \\
\text { significant infrastructure costs and operational } \\
\text { and regulatory requirements'. }\end{array}$ \\
\hline $\mathrm{U}$ & $\mathrm{U}$ & $\mathrm{U}$ & $\mathrm{N}$ & $\begin{array}{l}\text { Billete Digital } \\
\text { Uruguay }\end{array}$ & $\begin{array}{l}\text { Pilot; 'Digital bills that aim to have same } \\
\text { functions and uses as physical bills'; ongoing } \\
\text { evaluation. }\end{array}$ \\
\hline $\mathrm{U}$ & $\mathrm{U}$ & U & $\mathrm{N}$ & $\begin{array}{l}\text { E-shekel } \\
\text { Israel }\end{array}$ & $\begin{array}{l}\text { Research; 'help in the struggle against } \\
\text { unreported transactions'; 'contribute to the } \\
\text { high-tech sector (fintech)'; Conclusion that } \\
\text { 'the team does not recommend that the Bank } \\
\text { of Israel issue digital currency (e-shekel) in the } \\
\text { near future'. }\end{array}$ \\
\hline
\end{tabular}


Table 1.1: Continued

\begin{tabular}{|c|c|c|c|c|c|}
\hline \multicolumn{4}{|c|}{ Design choices } & \multirow{2}{*}{$\begin{array}{l}\text { Project/ } \\
\text { Country } \\
\text { CBDC series } \\
\text { New Zealand }\end{array}$} & \multirow{2}{*}{$\begin{array}{l}\text { Notes on status, motivation and conclusion } \\
\text { Research; 'Safer and cheaper to transport } \\
\text { than cash'; 'Provides public access to an } \\
\text { electronic form of legal tender'; 'Reduces cash } \\
\text { demand and supply which could reduce the } \\
\text { availability of cash in an electricity outage'; 'Slow } \\
\text { payment authorisation in a blockchain-like } \\
\text { cryptocurrency'. }\end{array}$} \\
\hline $\mathrm{U}$ & $\mathrm{U}$ & $\mathrm{U}$ & $\mathrm{N}$ & & \\
\hline$\overline{\mathrm{U}}$ & $\mathrm{U}$ & $\mathrm{U}$ & $\mathrm{N}$ & $\begin{array}{l}\text { E-lilangeni* } \\
\text { Eswatini }\end{array}$ & $\begin{array}{l}\text { Research; 'evaluate whether clear use cases } \\
\text { exist for the introduction of a retail and/or } \\
\text { wholesale CBDC specifically within the context } \\
\text { of Eswatini. Findings from the first phase of } \\
\text { investigation indicate that there are indeed at } \\
\text { least three potential use cases'. 'However, while } \\
\text { these results are positive, further research is } \\
\text { warranted'. }\end{array}$ \\
\hline$\overline{\mathrm{U}}$ & $\mathrm{U}$ & $\mathrm{U}$ & $\mathrm{N}$ & $\begin{array}{l}\text { E-rupiah* } \\
\text { Indonesia }\end{array}$ & Research. \\
\hline $\bar{U}$ & $\mathrm{U}$ & $\mathrm{U}$ & $\mathrm{N}$ & $\begin{array}{l}\text { E-ringgit* } \\
\text { Malaysia }\end{array}$ & $\begin{array}{l}\text { Research; 'Pioneering work reviewed generally } \\
\text { concludes that CBDC, even if introduced in } \\
\text { the future, would likely be a complement rather } \\
\text { than a substitute to cash and bank deposits'. } \\
\text { 'Technological hurdles need to be considered, as } \\
\text { central bank credibility must take priority'. }\end{array}$ \\
\hline $\mathrm{U}$ & $\mathrm{U}$ & $\mathrm{U}$ & $\mathrm{N}$ & $\begin{array}{l}\text { E-won* } \\
\text { Korea }\end{array}$ & $\begin{array}{l}\text { Pilot; Start researching and reviewing } \\
\text { technology, process, legal framework. Test } \\
\text { if CBDC will technically work in a limited } \\
\text { environment. }\end{array}$ \\
\hline $\mathrm{U}$ & $\mathrm{U}$ & $\mathrm{U}$ & $\mathrm{U}$ & $\begin{array}{l}\text { E-dinar* } \\
\text { Tunisia }\end{array}$ & Research. \\
\hline$\overline{\mathrm{U}}$ & $\mathrm{U}$ & $\mathrm{U}$ & $\mathrm{U}$ & $\begin{array}{l}\text { E-rouble } \\
\text { Russia }\end{array}$ & Research. \\
\hline $\mathrm{U}$ & $\mathrm{U}$ & $\mathrm{U}$ & $\mathrm{U}$ & $\begin{array}{l}\text { Digital-dollar* } \\
\text { United States }\end{array}$ & $\begin{array}{l}\text { Research. 'the opportunities and challenges } \\
\text { of, as well as the use cases for, a CBDC, as } \\
\text { a complement to cash and other payments } \\
\text { options. }\end{array}$ \\
\hline
\end{tabular}


Table 1.1: Continued

\begin{tabular}{llllll}
\hline Design choices & & $\begin{array}{l}\text { Project/ } \\
\text { Country }\end{array}$ & Notes on status, motivation and conclusion \\
\hline U & U & U & U & $\begin{array}{l}\text { E-AUD } \\
\text { Australia }\end{array}$ & $\begin{array}{l}\text { Research. 'the case for issuing a CBDC for use } \\
\text { by households has not been established;' the } \\
\text { implications of CBDC for the structure of the } \\
\text { financial system would need to be carefully } \\
\text { considered. }\end{array}$ \\
\hline U & U & U & U & $\begin{array}{l}\text { Digital-Yen } \\
\text { Japan }\end{array}$ & Research. \\
\hline U & U & U & U & $\begin{array}{l}\text { E-franc } \\
\text { Switzerland }\end{array}$ & $\begin{array}{l}\text { Research; 'Examine the opportunities and } \\
\text { risks of introducing a cryptofranc (e franc)'; } \\
\text { 'additional benefits currently low, outweighed } \\
\text { by risks. }\end{array}$ \\
\hline
\end{tabular}

Notes:

Architecture: $\mathrm{D}$ = direct; $\mathrm{H}$ or $\mathrm{I}$ = hybrid or intermediated; $\mathrm{U}=$ unspecified or multiple options under consideration.

Infrastructure: $\mathrm{C}=$ conventional; $\mathrm{D}=\mathrm{DLT} ; \mathrm{U}=$ unspecified or multiple options under consideration.

Access: $\mathrm{A}$ = account-based; $\mathrm{A} / \mathrm{T}$ = tiering of account- and token-based; $\mathrm{T}$ = token-based;

$\mathrm{U}=$ unspecified or multiple options under consideration.

Interlinkage: $\mathrm{I}$ = international; $\mathrm{N}$ = national; $\mathrm{U}$ = unspecified or multiple options under consideration.

* Not an official designation by the central bank.

Source: Raphael Auer, Giulio Cornelli and Jon Frost, 'Rise of the Central Bank Digital

Currencies: Drivers, Approaches and Technologies', in BIS Working Papers, No. 880, August 2020, p. 39-41, https://www.bis.org/publ/work880.htm.

\section{References}

Tobias Adrian and Tommaso Mancini Griffoli, 'The Rise of Digital Money', in FinTech Notes, No. 19/01, July 2019, https://www.imf.org/en/Publications/ fintech-notes/Issues/2019/07/12/The-Rise-of-Digital-Money-47097

Itai Agur, Anil Ari and Giovanni Dell'Ariccia, 'Designing Central Bank Digital Currencies', in IMF Working Papers, No 19/252, 2019, https://www.imf.org/en/Publications/WP/Issues/2019/11/18/ Designing-Central-Bank-Digital-Currencies-48739

Sarah Allen et al., 'Design Choices for Central Bank Digital Currency: Policy and Technical Considerations', in NBER Working Papers, No 27634, August 2020, https://doi.org/10.3386/w27634

Hanna Armelius, Carl Andreas Claussen and Scott Hendry, 'Is Central Bank Currency Fundamental to the Monetary System?', in Sveriges Riksbank 
Economic Review, No. 2020-2, June 2020, p. 19-32, https://www.riksbank. se/globalassets/media/rapporter/pov/artiklar/engelska/2020/200618/ 2020_2-is-central-bank-currency-fundamental-to-the-monetary-system. pdf

Zachary Aron, Ulrike Guigui and Megan Scala, 'Getting Ahead of the Curve', in Deloitte Insights, 26 February 2020, https://bit.ly/2WFTLWW

Raphael Auer, Giulio Cornelli and Jon Frost, 'Covid-19, Cash, and the Future of Payments', in BIS Bulletin, No. 3, 3 April 2020, https://www.bis.org/publ/ bisbull03.htm

Raphael Auer, Giulio Cornelli and Jon Frost, 'Rise of the Central Bank Digital Currencies: Drivers, Approaches and Technologies', in BIS Working Papers, No. 880, August 2020, https://www.bis.org/publ/work880. htm

Christian Barontini and Henry Holden, 'Proceeding with Caution - A Survey on Central Bank Digital Currency', in BIS Papers, No 101, January 2019, https://www.bis.org/publ/bppdf/bispap101.htm

Morten Bech and Codruta Boar, Commentary on Red Book Statistics: Shaping the Future of Payments, November 2019, https://www.bis.org/statistics/ payment_stats/commentary1911.htm

Ansgar Belke and Edoardo Beretta, 'From Cash to Central Bank Digital Currencies and Cryptocurrencies: A Balancing Act Between Modernity and Monetary Stability', in Journal of Economic Studies, Vol. 47, No. 4, 2020, p. $911-938$

Codruta Boar, Henry Holden and Amber Wadsworth, 'Impending Arrival A Sequel to the Survey on Central Bank Digital Currency', in BIS Papers, No 107, January 2020, https://www.bis.org/publ/bppdf/bispap107.htm

Matthieu Bouchaud et al., Central Banks and the Future of Digital Money, ConsenSys White Paper, January 2010, https://cdn2.hubspot.net/hubfs/ 4795067/ConsenSys-CBDC-White-Paper.pdf

Markus K. Brunnermeier and Harold James, 'The Digitalization of Money', in NBER Working Papers, No. 26300, September 2019, https://www.nber.org/ papers/w26300

Markus K. Brunnermeier and Dirk Niepelt, 'On the Equivalence of Private and Public Money', in Journal of Monetary Economics, Vol. 106, October 2019, p. $27-41$

Elena Carletti et al., The Bank Business Model in the Post-Covid-19 World, London, Centre for Economic Policy Research, June 2020, https://voxeu.org/ node/65851 
Central Bank Digital Currencies Working Group (CBDC WG), 'Key Aspects around Central Bank Digital Currencies. Policy Report', in CEMLA Reports, May 2019, https://www.cemla.org/fintech/docs/2019-06KeyAspectsAroundBankDigitalCurrencies.pdf

Central Bank of the Bahamas, Project Sand Dollar: A Bahamas Payments System Modernisation Initiative, 24 December 2019, https:// www.centralbankbahamas.com/publications/main-publications/ project-sanddollar-a-bahamian-payments-system-modernization-initiative

Bhaskar Chakravorti, 'One Year After India Killed Off Cash, Here's What Other Countries Should Learn from It', in Harvard Business Review, 2 November 2017, https://hbr.org/2017/11/one-year-after-india-killed-offcash-heres-what-other-countries-should-learn-from-it

Grégory Claeys and Maria Demertzis, 'The Next Generation of Digital Currencies: In Search of Stability', in Bruegel Policy Contributions, No. 15, December 2019, https://www.bruegel.org/? $\mathrm{p}=33489$

Committee on Payments and Market Infrastructures, 'Central Bank Digital Currencies', in CPMI Papers, No 174, 12 March 2018, https://www.bis.org/ cpmi/publ/d174.htm

Seyed Mohammadreza Davoodalhosseini and Francisco Rivadeneyra, 'A Policy Framework for E-Money', in Canadian Public Policy, Vol. 46, No. 1, March 2020, p. 94-106, https://doi.org/10.3138/cpp.2019-010

Darrell Duffie, Digital Currencies and Fast Payment Systems: Disruption is Coming, Draft presented to the Asian Monetary Policy Forum, Singapore, 31 May 2019, https://www.darrellduffie.com/uploads/policy/ DuffieDigitalPaymentsMay2019.pdf

Juan J. Duque, 'State Involvement in Cryptocurrencies. A Potential World Money?', in The Japanese Political Economy, Vol. 46, No. 1, 2020, p. 65-82

European Central Bank (ECB), Virtual Currency Schemes: A Further Analysis, Frankfurt am Main, ECB, February 2015, https://www.ecb.europa.eu/pub/ pdf/other/virtualcurrencyschemesen.pdf

Jesús Fernández-Villaverde et al., 'Central Bank Digital Currency: Central Banking for All?', in NBER Working Papers, No. 26753, February 2020, https://www.nber.org/papers/w26753

Massimo Ferrari, Arnaud Mehl and Livio Stracca, 'Central Bank Digital Currency in an Open Economy', in CEPR Discussion Papers, No. 15335, October 2020, https://cepr.org/active/publications/discussion_papers/ dp.php?dpno $=15335$

G4S Cash Solutions, World Cash Report 2018, August 2019, https://www. g4scashreport.com 
Eddie Gerba and Margarita Rubio, 'Virtual Money: How Much do Cryptocurrencies Alter the Fundamental Functions of Money?', in Salomon Fiedler et al., The Future of Money. Compilation of Papers, Luxembourg, European Parliament, December 2019, p. 31-60, https://op.europa.eu/s/ on1P

Alex Gray, 'Cashless Payments Have Spiked During COVID-19, But Don't Expect Paper Money to Disappear', in Fast Company, 10 June 2020, https:// www.fastcompany.com/90514952

Neil Hartnell, 'Provider for Digital B\$ "Will Not Be Greedy", in The Tribune, 31 May 2019, http://www.tribune242.com/news/2019/may/31/ provider-digital-b-will-not-be-greedy

Jonas Hedman, 'Going Cashless: What Can We Learn from Sweden's Experience?', in Knowledge@Wharton, 31 August 2018, https://knlg.net/ 2LJhVH3

Kevin Helms, 'Central Banks Worldwide Testing Their Own Digital Currencies', in Regulation Bitcoin News, 15 August 2019, https://news.bitcoin.com/?p=328914 Simon Hess, Regulating Central Bank Digital Currencies: Towards a Conceptual Framework, 11 August 2020, https://dx.doi.org/10.2139/ssrn.3582501

Timothy Jackson and George Pennacchi, 'How Should Governments Create Liquidity?', in University of Liverpool Management School Working Papers, No. 202029, September 2020, https://www.liverpool.ac.uk/media/livacuk/ schoolofmanagement/research/economics/How,Should,Governments, Creat e,Liquidity.pdf

J.P Morgan, J.P Morgan Perspectives. Blockchain, Digital Currency and Cryptocurrency: Moving Into Mainstream?, 21 February 2020, https:// markets.jpmorgan.com/research/open/url/t59R6MoBP2TUkWA_ itSQBbfUlco1CmYnoNL3dA6WVSm82drJuOYLvdZIqDyuXyp-L4OrVEFw_ eAu4UgzicsInqAwjcbKIQHiPfGEjPF2Rt5PKUltFmEKGQaC3DeLBoW7

Todd Keister and Daniel Sanches, 'Should Central Banks Issue Digital Currency?', in Federal Reserve Bank of Philadelphia Working Papers, No. 1926, June 2019, https://doi.org/10.21799/frbp.wp.2019.26

Jinock Kim and Jaejung Kang, 'Money, to Be Publicly Issued, or Not to Be, That Is the Question', in The Journal of Internet Electronic Commerce Resarch, Vol. 19 , No. 5, 2019, p. 77-91

Trevor I. Kiviat, 'Beyond Bitcoin: Issues in Regulating Blockchain Transactions', in Duke Law Journal, Vol. 65, No. 3, December 2015, p. 569-608, https:// scholarship.law.duke.edu/dlj/vol65/iss3/4

Michael Kumhof and Clare Noone, 'Central Bank Digital Currencies - Design Principles and Balance Sheet Implications', in Bank of England Staff Working 
Papers, No. 725, May 2018, https://www.bankofengland.co.uk/workingpaper/2018/central-bank-digital-currencies---design-principles-andbalance-sheet-implications

Ohik Kwon, Seungduck Lee and Jaevin Park, Central Bank Digital Currency, Inflation Tax, and Central Bank Independence, 13 February 2020, http:// dx.doi.org/10.2139/ssrn.3581294

Marion Laboure and Jim Reid, The Future of Payments - Part I. Cash: the Dinosaur Will Survive... For Now, Deutsche Bank Research, 21 January 2020, https://www.dbresearch.com/PROD/RPS_EN-PROD/ PROD0000000000504353/The_Future_of_Payments_-_Part_I_Cash:_the_ Dinosau.pdf

Marion Laboure and Jim Reid, The Future of Payments - Part II. Moving to Digital Wallets and the Extinction of Plastic Cards, Deutsche Bank Research, 23 January 2020, p. 3, https://www.dbresearch.com/PROD/RPS_EN-PROD/ PROD0000000000504508/The_Future_of_Payments_-_Part_II_Moving to_Digita.pdf

Ashley Lannquist et al., 'Central Bank Digital Currency Policy-

Maker Toolkit', in World Economic Forum Insight Reports, January 2020, https://www.weforum.org/whitepapers/ central-bank-digital-currency-policy-maker-toolkit

Gerardo Licandro, Uruguayan e-Peso on the Context of Financial Inclusion, Presentation for the conference on 'Economics of Payments IX', Basel, 1516 November 2018, https://www.bis.org/events/eopix_1810/licandro_pres.pdf

Morten Linnemann Bech and Rodney Garratt, 'Central Bank Cryptocurrencies', in BIS Quarterly Review, September 2017, p. 55-70, https://www.bis.org/ publ/qtrpdf/r_qt1709f.htm

Udo Milkau, 'International Payments: Current Alternatives and Their Drivers', in Journal of Payments Strategy \& Systems, Vol. 13, No, 3, Fall 2019, p. $201-216$

Hossein Nabilou, Central Bank Digital Currencies: Preliminary Legal Observations, 6 February 2019, https://dx.doi.org/10.2139/ssrn.3329993

Dirk Niepelt, 'Digital Money and Central Bank Digital Currency: An Executive Summary for Policymakers', in VoxEU, 3 February 2020, https://voxeu.org/ node/65037

Dirk Niepelt, 'Reserves for Everyone - Towards a New Monetary Regime?', in VoxEU, 21 January 2015, https://voxeu.org/node/58510

Dinesh Shah et al., 'Technology Approach for a CBDC', in Bank of Canada Staff Analytical Notes, No. 2020-6, February 2020, https://www.bankofcanada.ca/ $? \mathrm{p}=209522$ 
Sveriges Riksbank, The Payment Behaviour of the Swedish Population, updated 20 November 2018, https://www.riksbank.se/en-gb/statistics/statistics-onpayments-banknotes-and-coins/payment-patterns

Sveriges Riksbank, The Riksbank's E-Krona Project Report 1, September 2017, https://www.riksbank.se/en-gb/payments--cash/e-krona/e-krona-reports/ e-krona-project-report-1

Sveriges Riksbank, The Riksbank's E-Krona Project Report 2, October 2018, https://www.riksbank.se/en-gb/payments--cash/e-krona/e-krona-reports/ e-krona-project-report-2

Amadou N.R. Sy, 'Fintech in Sub-Saharan Africa: A Potential Game Changer', in IMF Blog, 14 February 2019, https://blogs.imf.org/?p=25686

Stefan Thomalla and Marlene Schnippe, 'How COVID-19 Is Reshaping Retail Payments in Europe', in EY Insights, 17 June 2020, https://go.ey.com/ 2YN7Sul

Martina Weimert and Arnaud Saiag, COVID-19 and European Retail Payments, Oliver Wyman, June 2020, p. 3, https://www.oliverwyman.com/ourexpertise/insights/2020/jun/covid-19-and-european-retail-payments.html 
Massimo Cirasino

\section{Chapter 2: CBDC in the Broad Context of National Payments System Development}

Payment and settlement systems and services (PSSSs) have become vital components of the economic life of contemporary societies. They consist of integrated networks of institutions involved in the execution and delivery of fund transfer services across economies. Their smooth functioning is essential to the overall efficiency and stability of market economies. To ensure such smooth functioning, national oversight authorities have been established worldwide, typically with a leading role of central banks, and oversight activities have been developed to take account of the growing interconnectedness and mutual interdependence of PSSSs and other financial market infrastructures, including across borders. PSSSs constitute what is often referred as the national payments system (NPS) of each country, NPSs are also mutually interconnected in what can be referred to as the global payments system (GPS). ${ }^{1}$

The retail payments landscape, in particular, has changed significantly in view of drastic technological developments in the financial sector and changing consumer preferences. As these unfold, back-end and front-end arrangements that provide consumers with the ability to pay, save and transfer value have undergone remarkable improvements including, among other, the emergence of socalled fast or instant payment systems, the launch of new means of payment based on emerging technologies such as blockchain (e.g. virtual currencies, stable-coins), and the spread of additional access channels and enabling environments that accommodate the use of digital payments such as Quick Response (QR) codes and Application Programming Interfaces (APIs).

However, despite the rise of digital payments, evidence suggests that cash remains the most widely used retail payment instrument around the world. ${ }^{2}$ As

1 This chapter reflects discussions held in the context of the preparation of 'Central Bank Digital Currencies: the Payments Perspective', a World Bank paper to be published in January 2021. Hence, its ideas and insights also belong to Holti Banka, Biagio Bossone, Ahmed Faragallah, Maria Chiara Malaguti, Harish Natarajan and Gynedi Srinivas. Errors and omissions are the sole responsibility of the author.

2 Cash in the form of physical banknotes and coins issued by the central bank or the government is referred to as 'physical cash' throughout this chapter. 
such, central banks, enabled also by new technologies, have been exploring the issuance of a digital instrument with cash-like features - central bank digital currency (CBDC). CBDC can be defined as a liability of (claim on) the central bank issued in digital form, which can be used as a medium of exchange and means of payment, store of value, settlement asset and unit of account. CBDC can be token-based or account-based and it can be wholesale or retail. A retail CBDC (RCBDC) is used like a digital extension of cash by all players in the economy, whereas a wholesale CBDC (W-CBDC) could be used only by permitted institutions as a settlement asset in the interbank market.

Although it can be argued that most central banks already issue wholesale $\mathrm{CBDC}$ and that a W-CBDC would just be an evolution of existing systems, in recent years several central banks have been testing and piloting the CBDC concept in the retail space as an innovative development. There is recognition of the complexity associated with such an initiative, given that it cuts across multiple areas: payment system development, monetary policy, financial stability, legal, and oversight, as well as the practical challenges of implementation. Nevertheless, central banks want to be well-positioned in the new era of payments and not be overshadowed by the private sector.

Depending on their circumstances and local context, central banks are guided by different drivers in their desire to explore the issuance of CBDC. The main drivers can be broadly summarized as follows.

- Cost: The high cost associated with the printing, handling, storage and transport of physical cash is pushing central banks to consider less costly versions of currency, such as CBDC.

- Financial inclusion: As many emerging markets are facing significant gaps in access to transaction accounts and usage of digital payment instruments, CBDC could potentially constitute a solution toward universal access.

- Instant access: Given that access to information is instant in today's era, there has been a growing demand from consumers and businesses for payment mechanisms that allow instant and continuous access to funds on the payee's side.

- Risk: In some countries (e.g. Sweden), most retail payments are digital (enabled by privately issued payment instruments), which implies high levels of dependence on the private sector. By implementing CBDC, central banks can shift some of that risk back to the central bank, as the CBDC will compete with privately issued digital payment instruments. 
- Competition: Given that similar initiatives are being undertaken by the private sector (e.g. Libra), central banks do not want to be left behind or outcompeted by the private sector in the payments sector, where they also have a role to play.

- Role of central banks: Central banks have gone beyond their traditional role of issuing currency and are also serving as retail payment system operators in many cases, thus dealing directly with market participants and end users. This positions them to potentially undertake the CBDC project, which requires cooperation and interaction with many different stakeholders.

- Seigniorage: CBDC can boost seigniorage revenue for central banks, given the low production cost compared to physical cash.

- Technology advancements: New emerging technologies, including blockchain, have made the implementation of CBDC easier.

- Cross-border transactions: If designed for cross-border transfers/payments, CBDC can lower costs significantly for such transactions.

- Tax collection: Many jurisdictions believe that CBDC can increase transparency and significantly reduce tax evasion, because transactions can be tracked, even under an anonymous CBDC design.

- Capital market development: some forms of CBDC could match more modern techniques for clearing and settlement of securities and derivatives, and facilitate delivery versus payment in these new environments.

The implementation of CBDC comes with dilemmas, risks and challenges. Central banks need to make important decisions regarding the design of CBDC, such as interest bearing or non-interesting bearing; token-based or accountbased; anonymous or non-anonymous; accounts held at central bank or at commercial institutions; and cost structure and fees charged to participants and end users. These are some key questions that need to be answered in advance. In addition, there are risks and challenges that pertain to, for example, how monetary policy will be affected by the issuance of CBDC and how the Anti money laundering and counter financing of terrorism (AML/CFT) mechanisms in payments through CBDC will be handled.

Overall, it is important for central banks to have a clear objective so they can decide first whether CBDC is the right instrument and whether other existing mechanisms can fulfil the objective. Even if the solution is indeed CBDC, the implementation and design features will have to be guided by the needs of the implementer. Finally, determining the right timing for the introduction of $\mathrm{CBDC}$ is of utmost importance, as this could influence the success of the project and adoption of the instrument. 


\subsection{CBDC in the broad context of national payments system development}

From an NPS perspective, the decision on whether, when, how and by whom a CBDC should be introduced is complex and needs to be taken with close attention to some important considerations. As the NPS in almost every country is far from optimal efficiency, $\mathrm{CBDC}$ has the potential to reduce costs and improve user experiences by putting competitive pressure on existing payment instruments.

Some potential advantages of the introduction of $\mathrm{W}-\mathrm{CDBC}$, as an advanced version of existing real time gross settlement (RTGS) systems, are:

1. Longer operating hours: W-CBDC is likely to be available $24 / 7,365$ days a year, unlike RTGS systems.

2. Increased operational resilience: $\mathrm{W}-\mathrm{CBDC}$ is expected to run on a permissioned network, relying on several cloud based nodes instead of the two to three data centres common to RTGS systems. However, one could argue that current systems are already resilient and do not need extra levels of resilience.

3. Tokenization of financial assets: the financial industry is making huge efforts to tokenise financial assets, such as securities (e.g. SDX or HQLAx). These platforms will require tokenised money like W-CBDC for settlement purposes.

Some potential advantages of the introduction of a (domestically used) RCBDC are:

1. Reduced cost for the production, handling and distribution of physical cash. Comparative cost studies will be instrumental to measuring this impact.

2. Increased competitive pressure on the efficiency of other payment instruments. As a RCBDC will be offered, in principle, at little or no cost to payers and payees, it could improve the overall efficiency of the retail segment of the NPS by putting pressure on other instruments that will have to 'market' their other characteristics and advantages. It remains to be seen how CBDC features will be designed.

3. A more stringent anti-money laundering/know your customer (AML/KYC) regime than physical cash. This will depend on the RCBDC model selected: (i) pure value-based CBDCs present similar concerns to cash; (ii) account-based CBDCs could mitigate AML/KYC concerns.

4. Easier way to measure the real circulation of cash. 
5. Capacity to attract underserved or unserved segments of the population to increase financial inclusion.

Some potential advantages of the introduction of an (internationally used) $\mathrm{RCBDC}$ are:

1. Efficiency gains for cross-border payments, in particular at the regional level, as CBDC can serve as a cost-effective and faster payment means or an efficient settlement asset.

2. Positive impact on de-risking as global reserve currencies issued as CBDCs could replace some correspondent banking arrangements.

3. For smaller states, it could increase demand for the national currency.

The decision on CBDC should follow a structured and strategic approach, for which four main recommendations are provided below.

Recommendation A: Preliminary considerations for successful launch of a CBDC. Before embarking on a structured programme to launch a CBDC in any given country, the central bank, other government authorities and relevant stakeholders should engage in a careful analysis of the following ten (10) considerations:

1. Be informed! The decision on whether, when, how, and by whom a CDBC should be launched should be based on a full understanding of the NPS structure and needs, and on reliable and comprehensive data. In this regard, relevant data might be available through a cost study executed using the World Bank (WB) comprehensive methodology. ${ }^{3}$ This set of data would be instrumental in guiding strategic decisions on this matter. Also, the WB guidance on retail payment system stocktaking ${ }^{4}$ can provide some helpful insights (see Annex 1).

2. Be strategic! The introduction of any form of CBDC should be part of and coherent with a strategic plan of reform of the NPS. In principle, the introduction of a CBDC is in line with the broad objectives of NPS reforms.

3 The World Bank has developed a methodology to run such analysis. See World Bank, Retail Payments. A Practical Guide for Measuring Retail Payment Costs, Washington, World Bank, November 2016, http://hdl.handle.net/10986/25861. For an application of this methodology, see World Bank and Bank of Albania, The Retail Payment Costs and Savings in Albania, Washington, World Bank, June 2018, http://hdl.handle.net/ $10986 / 30060$.

4 World Bank, Banco Central do Brasil and European Central Bank, A Practical Guide for Retail Payments Stocktaking, Washington, World Bank, 2012, https://web.worldbank. org/archive/website01530/WEB/IMAGES/WB_2012_.PDF. 
However, a careful attention of the potential trade-offs among the different strategic directions of the plan will need to be given (see also the following considerations).

3. Be safe! CBDC, both wholesale and retail, should adhere to the highest standards of safety and security. For example, W-CBDC should fully observe the CPMI-IOSCO Principles for Financial Market Infrastructures (PFMIs) ${ }^{5}$ (see Annex 2). Both wholesale and retail CBDCs should be subject to stringent cyber risk management. RCBDCs should be subject to strict measures to avoid counterfeiting and token manipulation, as well as having adequate consumer assistance and protection mechanisms.

4. Inject efficiency! CBDC, wholesale and retail, should contribute greatly to improving the overall efficiency of the NPS. As mentioned above, the analysis of relevant data, including through the use of the WB cost study, would shed light on where to intervene to enhance NPS efficiency in the country. Should, for example, the study reveal that there are significant costs in producing and handling cash in the economy, and should some doubts remain on the capacity of the financial sector to foster the adoption of digital payments, then the introduction of an RCBDC could be accelerated. On the wholesale side, a careful and urgent assessment of the current and prospective RTGS arrangements in relation to the efficiency principles of the CPMI-IOSCO PFMIs would inform any decision. Some additional guidance on this matter can be provided in the relevant standards/guidance ${ }^{6}$ (CPSS NPS Guidance report, see Annex 3) and in the WB retail package. ${ }^{7}$

In the broad NPS development framework. CBDC can significantly improve disbursement and collections of government payments (see Annex 4 for the World Bank Guidelines for GPS $)^{8}$ and can facilitate handling emergency situations (see Annex 5).

5 Committee on Payment and Settlement Systems (CPSS) and International Organization of Securities Commissions (IOSCO), Principles for Financial Market Infrastructures, Basel, Bank for International Settlements, April 2012, https://www.bis.org/cpmi/publ/ d101a.htm.

6 Committee on Payment and Settlement Systems (CPSS), 'General Guidance for Payment System Development', in CPMI Papers, No 70 (January 2006), https://www. bis.org/cpmi/publ/d70.htm.

7 Massimo Cirasino and Jose Antonio Garcia (eds), Developing a Comprehensive National Retail Payments Strategy, Washington, World Bank, 2012, http://documents. worldbank.org/curated/en/839121469729131991.

8 World Bank, General Guidelines for the Development of Government Payment Programs, Washington, World Bank, 2012, http://hdl.handle.net/10986/22127. 
5. Be fair! CBDC, in particular retail, should integrate smoothly with other payment instruments/schemes and foster a competitive environment within the NPS. In this context, the WB guidance and the spirit of competing on services and cooperating on infrastructures should help policymakers make the right choices (see Annexes 6 and 7). In particular, in some cases, consideration should be given to the choice between a $\mathrm{CBDC}$ and the introduction of faster payments solutions that are being launched in several countries. In principle, RCBDC and faster payments provide a similar experience to endusers in that the availability of funds is immediate. However, there are some important considerations in terms of finality, anonymity, intermediation, and cost that would probably lead to the co-existence of both instruments, in the same way physical cash co-exists with other payment instruments. The fact that, in some countries, central banks would be behind both initiatives would call for a careful analysis of the implications and planning of the timing of their launch.

6. Foster inclusion! CBDC, in particular retail, should be consistent with financial inclusion objectives. The prospective CBDC should be consistent with the framework defined by the CPMI-World Bank Guiding Principles for the Payment Aspects of Financial Inclusion (PAFI), (see Figure 2.1) and the recently issued report on 'Payment aspects of financial inclusion in the fintech era.'

7. Be neutral! $\mathrm{CBDC}$, in particular retail, should maintain at least the same level of AML-CTF compliance that existed before its introduction. Relevant Financial Action Task Force (FATF) provisions should be studied and applied as needed to the prospective CBDC. In this context, a study of the AML-CTF perspective on the NPS in the country would be beneficial.

8. Help the world! CBDC, both wholesale and retail, where used for crossborder purposes and/or international remittances should enhance the efficiency and safety of the GPS. The CPSS-WB General Principles for International Remittance Services $^{10}$ (see Annex 8) and the recent CPMI

9 The full reports can be downloaded at the following links: Committee on Payments and Market Infrastructures (CPMI) and World Bank, 'Payment Aspects of Financial Inclusion', in CPMI Papers, No. 144 (April 2016), https://www.bis.org/cpmi/publ/d144. htm; CPMI and World Bank, 'Payment Aspects of Financial Inclusion in the Fintech Era', in CPMI Papers, No. 191 (April 2020), https://www.bis.org/cpmi/publ/d191.htm.

10 Committee on Payment and Settlement Systems (CPSS) and World Bank, 'General Principles for International Remittance Services', in CPMI Papers, No. 76 (January 2007), https://www.bis.org/cpmi/publ/d76.htm. 


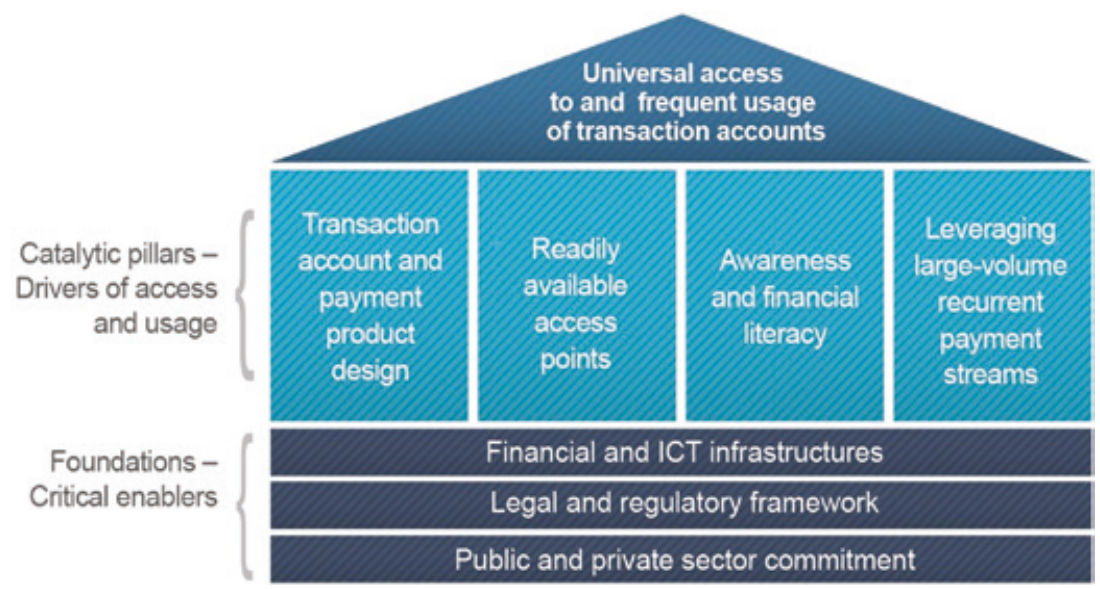

Figure 2.1: The PAFI framework.

Retail and Cross-border reports can provide important guidance on this matter. In some countries, these cross-border and remittance dimensions can probably become relevant at a subsequent stage, depending on the level of adoption of the CBDC.

A general perception is that cross-border payments lag behind domestic ones. A recent assessment by the Financial Stability Board (FSB) of existing payment arrangements has identified four types of important challenges: cost, speed, access and transparency. ${ }^{11}$ These challenges affect a number of different stakeholders on the supply side (bank and non-bank payment system operators or PSPs and technical service providers) and the demand side (end users composed of individuals, businesses and government agencies), and affect each of them in different ways.

9. Be collegial! The decisions on whether, when, how and by whom a CBDC should be introduced, as well as those regarding its implementation (if it is approved) should be made through a structured process of consultation with all relevant stakeholders. Central banks, typically, engage with all relevant stakeholders in the production of the NPS strategy and some of its implementation. In this spirit, a cooperative approach should be followed,

11 See Financial Stability Board (FSB), Enhancing Cross-border Payments. Stage 1 Report to the G20: Technical Background Report, 9 April 2020, https://www.fsb.org/wp-content/ uploads/P090420-2.pdf. 
with the possible creation of a working group in the context of a plan to create a National Payments System Council or Forum, where this is not already in place.

10. Implementation is key! CBDC, both wholesale and retail, should be subject to rigorous pre-planning and project management techniques, and should protect central banks from reputational risk. This would not be different from other NPS reform projects, with the possible caveat of an even stronger reputational role for the CBM. The WB Guidelines for Integration of Regional Infrastructures ${ }^{12}$ provide some important insights on how to structure decision-making and implementation processes in the payments field (see Annex 9 and Recommendation C).

Recommendation B: Legal and regulatory aspects. The issuance of $C B D C$ requires a careful consideration of its legal and regulatory consequences. ${ }^{13}$ Therefore, the central bank, in cooperation with other relevant authorities, should carefully review the legal and regulatory framework prior to the launch of a $C B D C$.

A few premises are required. In the first place, each legal order has its own institutional setting and substantive provisions. Consequently, any concrete analysis should rely on the actual legal context of the relevant jurisdiction. In the second place, constraints might exist in legal orders; however, this would not impede the establishment of CBDC, but possibly force some decisions or require amendments to legislation and/or new regulation. Finally, legal and economic concepts do not always exactly match and consequently an assessment is always required of the scope of legal definitions to correctly transpose the aims to be attained under policy into legal and regulatory terms.

CBDC against cash and fiduciary money: $\mathrm{CBDC}$ implies a reconsideration of legal tender. The central bank needs to have the authority to issue CBDC. In general, central banks do have the general power to issue currency. Unless relevant legislation expressly states otherwise, the central bank should thus be able to issue currency also in digital form. However, a more subtle issue may arise as for the legal value of CBDC to extinguish obligations.

Considering CBDC as legal tender could not automatically imply a duty by the creditor to accept a specific payment instrument. Legal tender should thus be recognized to take the form of reserves, cash and CBDC. However, a different

12 World Bank, Guidelines for the Successful Regional Integration of Financial Infrastructures, Washington, World Bank, 2014, http://hdl.handle.net/10986/22110.

13 This legal part draws significantly from inputs received from Maria Chiara Malaguti (World Bank). 
matter concerns acceptance of payment instruments through which the means of payment is delivered. As a matter of principle, parties should be free to agree on the kind of instrument they are ready to accept according to cost, needed technology, or risk. As stated above in this paper, CBDC is issued and then embedded into a payment instrument, possibly regulated through a scheme and processed through a system. To that end, CBDC is embedded into a payment product which competes with other payment products in the market.

In the lack of clarification within each legal order of the above categories, the introduction of CBDC may create some inconsistencies, since CBDC, as liability of the central bank, would possibly be considered as legal tender, with the consequence that its acceptance would be compulsory under many legal systems, although the creditor might not be equipped from a factual point of view to be paid under its terms.

To the same extent, as a way of exception to the general principle that parties should freely choose payment instruments, there may be public policy justifications requiring the regulator to impose some restrictions in the use of a payment instrument against another. This is well-known to the generality of countries, where thresholds are often imposed in the use of cash, e-money or cheques. A different understanding of the above issues may reduce the autonomy of the central bank to manage its policies by imposing restraints on the use of a kind of payment instrument against another.

The issuance of CBDC must not be in conflict with the statutory functions of the central bank or possible constraints on its activities. Once it is ensured that a central bank can issue CBDC because this is a means of payment as reserves and cash are, and that this is legal tender, a second check might be needed in the light of the objectives and functions of the central bank as established by its statute.

If a central bank issues a CBDC to the general public, it is potentially exposed to the same legislation as other payment services providers or system operators. Functions of a central bank often include also the power to operate a system. Rarely such power would be statutorily limited to wholesale systems. However, it has been quite unusual until now for a central bank to directly provide payment services to the general public besides physical cash, as it could be the case under models where it is the central bank itself to distribute the product and to have direct relationships with the users. In all these operational roles, the central bank should in principle be subject to the same standards as any other provider in the market, as well as the product distributed should be subject to the same rules as competing products. This would make the central bank subject to general legislation on payments. In addition to anti-money laundering regulations, such as KYC regulations and overseeing transactions, this might involve data 
protection legislation, consumer protection legislation in the payment services field, responsibility for unauthorized transactions, tax legislation and the like. The regulatory framework to apply would depend on which option is chosen, but in principle the central bank should be subject to the same provisions as any other market participant issuing similar DC mechanisms (see below for oversight). It needs to be noted, however, that a counter-argument is that physical cash - the most used payment instrument in the world and issued by the central bank, is not necessarily following the same standards and provisions as other payment instruments and this can be in principle extended to CBDC, as well.

It should yet be clarified that CBDC is not e-money. E-money products are issued by regulated entities and are pre-paid products. The customer has a specific amount registered on a devise for payments against actual delivery of fiat money to the intermediary, who will manage it according to relevant legislation. This happens mainly by depositing funds received from customers at deposittaking institutions under fiduciary accounts, which the intermediary manages as a trustee (or analogous institution) to the benefit of the customers. From a legal standpoint, this means that the trustee or other fiduciary holder has the power to administer the founds but it does so not to its own benefit, but to that of the customer, who is the beneficiary owner of such funds. These legal structures are often misinterpreted: the fact that the customer is the beneficial owner of the funds deposited at the deposit taking institution - with the consequence that in the event of default by the intermediary such funds are not included within the intermediary's property -, does not mean that the relationship between the intermediary and the customer changes: the customer keeps having a claim against the intermediary for the execution of its payment obligations. Even under the circumstance that such accounts are held at a central bank rather than at a commercial bank, such pre-paid instruments rely on the liability of the intermediary. E-money products and CBDC thus do not coincide, since the latter represents a liability of the central bank. However, e-money legislation, which currently exists in many countries, does not always define 'e-money' as such in the same way. In particular, under some legislation the definition does not specifically clarify that e-money must be issued against fiat money. This may generate uncertainties on whether such legislation would apply also to digital currency in general, and to CBDC in particular. In the light of the structural difference between the two instruments, it would be advisable that a clear distinction is made. However, it cannot be excluded that some of the provisions applying to e-money products could equally apply to the CBDC, such as on AML, authorization, verification, protection of data. 
Legal issues for cross-border CBDC have additional implications. CBDC for cross-border payments is inherently exposed to a plurality of legal systems. Anything that crosses borders implies that it is potentially subject to (at least) two different legal systems. These systems do not necessarily have similar rules governing the same events or contingencies. And even when some similarities exist, such as, for instance, when international standards apply to both systems, the actual application of the same standards in each country might vary or even be in conflict. Conflicting standards and, even worse, conflict of laws engender the risk that the expected effects of a transaction may not materialise or that unexpected consequences might occur.

Any CBDC that is legally issued in a country should be fully recognised in other countries. If, in the issuing country, the central bank has the authority to issue a CBDC, any other country should accept this CBDC as the currency of the issuing country in the same way as it accepts foreign currencies of any other form. This means that the legal issues associated with CBDC transfers should be the same as those associated with any other cross-border transfers. A situation where a country accepts a foreign currency under a specific form, say cash, while it refuses another currency under another form (hypothetically, CBDC) would be inconceivable in legal terms, especially if the latter is understood to be a means of payment and not a commodity (as is the case with CBDC). However, in view of the fact that CBDC also permits non-residents, at least in principle, to freely purchase domestic currency, thus placing both currencies (as means of payment) in much greater competition with each other than is currently the case, the circumstance cannot be ruled out wherein the receiving country would impose limitations on CBDC use within its jurisdiction in order to safeguard its own currency.

Finally, standards and regulations need to be tailored to the CBDC model chosen. For W-CBDCs, the major concern is the sound operation of the supporting infrastructure. To that end, regulatory inconsistencies might emerge if, for instance, different criteria exist for the authorization of financial institutions as participants, or if different conditions apply for access of participants to central bank systems and facilities or to open accounts at central banks. These differences do not affect the legal soundness of the infrastructure, but they may rather weaken its efficiency and obstruct the achievement of its goals. However, in the case of general purpose CBDCs, the protection of end users become a relevant concern in addition to operational soundness. In this area, however, countries may have different legal provisions for (financial) consumer protection, financial integrity, data collection and protection, and transparency (in particular as for traceability and transparency of fees and costs). 
Such differences among countries participating in a CBDC infrastructure for cross-border payments would not affect the legal soundness of the payments or the infrastructure as a whole, but they might affect the achievement of common regulatory standards for the use of the same CBDC across the jurisdictions involved, and ultimately alter the homogeneous quality of CBDC services to the public across the whole arrangement.

Recommendation C: Project management and resources. The central bank should prepare a realistic action plan, identifying relevant milestones for the implementation of the $C B D C$ and should count on adequate human and financial resources.

The action plan should include a feasibility phase, pilot phase and the (potential) full-scale implementation phase. In the feasibility phase, the central bank should consider the various design options for a CBDC), analyse the relevant data, compare them with the needs and elaborate on a model for the CBDC in the country. The pilot phase should be regarded as critical, and entering it, the central bank should be open to any outcome, including the possibilities of having to significantly change the original design or drop the project altogether.

The central bank should carefully check what the resources will be needed for implementing a CBDC, keeping in view other NPS reform projects underway. The complexity and cost of implementing a CBDC should not be underestimated; it is neither easy nor resource-free. Therefore, all necessary resources, financial and human, internal and external to the central bank, should be available and ready to be deployed effectively.

Here one can draw extensive lessons from the WB regional guidelines for the successful implementation of regional financial infrastructures.

Recommendation D: NPS oversight implications. ${ }^{14}$ The launch of a CBDC might have implications on the role of the central bank as overseer of the NPS, which should be carefully evaluated and, eventually, addressed.

Increasingly, since the late 1990s, central banks have redefined their role as oversight agencies for the NPS. Most central banks today have in place a policy framework for NPS oversight, which they periodically revisit based on the evolution of the NPS as influenced by ongoing institutional and technological developments. ${ }^{15}$ Interest has arisen from financial regulators and the payments

14 This section draws extensively on contributions from Gynedi Srinivas (World Bank).

15 In two path-breaking papers, the Banca d'Italia $(1997,1999)$ outlined the main features of payment system oversight that were then taking shape and reported the results of a survey of the oversight functions then carried out by central banks in leading industrial countries. Another early example of the attempt to set out explicit objectives for oversight at a time when detailed statutory guidance was yet undeveloped is the Bank 
industry on how to organise the oversight function in a way that is most conducive to a sound long-term balance among the various objectives. ${ }^{16}$

Oversight as it has evolved over the years and been practiced by central banks has been based on the premise of promoting safety and efficiency of payment and settlement systems by 'monitoring existing and planned systems, assessing them against these objectives and, where necessary, inducing change. ${ }^{17}$ The definition encompasses the 'public policy objectives of oversight (safety and efficiency), its scope (payment and settlement systems) and its activities (monitoring, assessing and inducing change)'. Additional public policy objectives such as financial inclusion, consumer protection and standards for payment instruments also fall under the scope of oversight in the case of central banks.

The oversight powers of central banks have been broadly seen to cover and capture the above elements either in new payments system laws or through amendments to existing laws such as central banking laws. These powers of oversight by and large do not always capture the likely development, deployment and use of a CBDC either as a retail payment instrument or as a wholesale settlement asset, given that this is an idea that has gained traction only recently. Nonetheless it is interesting to analyse how the concept of oversight can be applied to CBDCs.

RCBDCs: The RCBDC would be a general purpose digital payment instrument that would be available to the general public either as a token-based variant or an account-based variant. A token-based variant would largely be a type

of England's report on Oversight of Payment Systems, issued in November 2000. Finally, see World Bank-CEMLA work by Bossone and Cirasino, where a template for the oversight of PSSS was first designed for the central banks of emerging market economies, and which has since become the oversight policy 'manifesto' for many central banks worldwide. See Biagio Bossone and Massimo Cirasino, 'The Oversight of the Payments Systems: A Framework for the Development and Governance of Payment Systems in Emerging Economies', in Western Hemisphere Payments and Securities Clearance and Settlement Systems Research Series, No. 1 (July 2001), http://documents.worldbank. org/curated/en/646651468156578578.

16 For a review of oversight issues, see contributions reported in Bruce J. Summers (ed.), Payment Systems: Design, Governance and Oversight, London, Central Banking Publications, 2012. For a discussion of how public policy considerations and goals influence the design and operation of systems, see Bruce J. Summers, 'Payment System Design and Public Policy', in Bruce J. Summers (ed.), Payment Systems: Design, Governance and Oversight, London, Central Banking Publications, 2012, p. 3-16.

17 Committee on Payment and Settlement Systems (CPSS), 'Central Bank Oversight of Payment and Settlement Systems', in CPMI Papers, No. 68 (May 2005), p. 11, https:// www.bis.org/cpmi/publ/d68.htm. 
of 'digital cash' and could be distributed to the general public in various ways, compared to an account-based variant. Aimed primarily at retail transactions, it would be widely available. ${ }^{18}$

Token RCBDC: If one were to conceptualise a token RCBDC as a bearer instrument akin to cash/bank notes, widely available to the general public for daily payment needs, the issue that needs to be determined is whether the issuance, circulation/distribution, redemption, destruction, operational reliability, security and customer redressal issues would all fall under the purview of NPS oversight. Physical cash issued by the central bank is a bearer instrument and the central bank's oversight scope and powers do not extend over cash comprising bank notes, which are legal tender. Other departments within the central banks are tasked with the responsibility of bank-note design, their security features, distribution mechanisms, destruction of soiled bank notes and customer redressal (exchange of soiled or mutilated bank notes). Other authorities such as law enforcement work with central banks and their distribution entities (usually banks) to detect forged notes and prosecute those responsible.

A case could be made out that since other units of the central bank have been successfully managing the life-cycle of bank notes, with adequate re-skilling and training they would be able to do the same with token RCBDC as well. Seen from this perspective, NPS oversight does not appear to have any role in the oversight (monitoring, assessing and inducing change) of token RCBDC.

It could also be the case that the general public would not like to have on their person the full value of a bearer instrument (token RCBDC) and may like to store some balance in an account to be used as and when required. When token RCBDC can be stored in an account (either with the central bank or with other authorised entities), such arrangements could fall outside the traditional scope of NPS oversight. Other departments within central banks are responsible for managing the accounts of entities permitted to hold accounts with central banks and more often than not the internal audit unit of the central bank is tasked with ensuring that the department handling the accounts (within the central bank) is functioning in a safe and efficient manner. Where accounts are held with banks, the banking supervisors would prescribe guidelines for opening accounts for customers, along with customer redressal measures. One could surmise that perhaps NPS oversight could play a role in prescribing account opening criteria

18 Codruta Boar, Henry Holden and Amber Wadsworth, 'Impending Arrival - A Sequel to the Survey on Central Bank Digital Currency', in BIS Papers, No. 107 (January 2020), https://www.bis.org/publ/bppdf/bispap107.htm. 
(including customer redressal measures) where RCBDC accounts are held with non-bank providers licensed by NPS oversight.

Seen from the above perspective, one could infer that the role of oversight over RCBDCs is rather circumscribed. But this need not always be the case. Where an RCBDC is the payment instrument used by the general public, it could be argued decisively that NPS oversight has a role in the safe and efficient functioning of the retail payment system (whether operated by the central bank or a private PSP) to fulfil its objectives in maintaining public confidence in money and in the systems used to transfer money.

As a ready reckoner (using the ECB framework for card payments), if one were to analyse the above retail payment system (which uses RCBDC) as a 'scheme', then it becomes very evident that NPS oversight has a role. The ECB defines a card payment scheme as

the set of functions, procedures, arrangements, rules and devices that enable a holder of a payment card to effect a payment and/or cash withdrawal transaction with a third party other than the card issuer. The oversight framework covers the entire payment cycle, i.e. the transaction phase (including the manufacture of payment instruments and the processing of data) and the clearing and settlement phase. It accommodates concerns relating to both the retail payment system and the payment instrument used. ${ }^{19}$

The above framework can be applied ipso facto to an RCBDC payment arrangement by replacing payment cards with the RCBDC. Adopting a 'scheme' framework allows the overseer to conduct oversight over the entire payment cycle comprising the generation/manufacturing, data processing, and the associated clearing and settlement of transactions using the RCBDC.

While taking the view that the life-cycle management of an RCBDC as a payment instrument could be the responsibility of other departments within the central bank, it becomes necessary that under a 'scheme' framework (as outlined above), the NPS oversight department is fully co-opted in this process (security, design, distribution of RCBDC) by the central bank management. A case could also be made that as RCBDC is a new payment instrument, it should be the operations department which should be tasked with the life-cycle management of the RCBDC. Whichever arrangement is chosen, it should be recognised that this would be a central bank function in which various departments of the central bank would have to work together, including NPS oversight, given the

19 European Central Bank (ECB), Oversight Framework for Card Payment Schemes Standards, January 2008, p. 6, https://www.ecb.europa.eu/pub/pdf/other/oversightfw cardpaymentsss200801en.pdf. 
adoption of a 'scheme" framework. Based on the above, it becomes evident that oversight has a vital role to play in the life-cycle management of RCBDC as a retail payment instrument. Based on the motivations (financial inclusion, alternative to commercial bank money, etc.) of the central bank for issuance of the RCBDC, the oversight unit should contribute to the security and design features of the RCBDC to ensure that it is neutral in terms of form-factor (through a card, smartphone app, a feature phone, etc.) and technology, and is widely available for use. These inputs from the oversight unit would help realise the objectives of the central bank.

However, when it comes to the clearing and settlement phase, it should be recognised that it would be the exclusive domain of the oversight unit within the central bank, as they are tasked under the oversight function to ensure the safe and efficient functioning of payment and settlement systems. This is because payment clearing and settlement systems facilitate the exchange of money (in this case RCBDC) for goods and services (and possibly financial assets), and if they were inefficient or failed altogether, money (RCBDC) would not fulfil this purpose effectively, and that could impair public confidence in RCBDC and in the systems used to transfer it. ${ }^{20}$

As part of the oversight process, a subset of the PFMI could be adopted to ensure that the clearing and settlement arrangements are safe and efficient. The choice of principles in the subset would largely be dependent on parameters such as the volume and value of transactions being cleared and settled, limits to individual transaction values, and the choice of clearing and settlement mechanisms used. The subset would typically comprise principles to manage and mitigate financial risk (include governance and access criteria), and measures to mitigate operational risk (including cyber risks) and improve efficiency. It should also be recognised that it may not be the case that all key considerations associated with individual principles are attracted in this process.

W-CBDC: A payment system using W-CBDC would lend itself to be classified as a systemically important payment system (SIPS) as it is presumed that it would be used to process and settle time-critical, high-value payments in the economy, among others. ${ }^{21}$ Based on this premise, a W-CBDC payment arrangement will

20 CPSS, 'Central Bank Oversight of Payment and Settlement Systems', cit.

21 'In general a payment system is systemically important if it has the potential to trigger or transmit systemic disruptions; this includes, among other things, systems that are the sole payment system in a country or the principal system in terms of the aggregate value of payments; systems that mainly handle time-critical, high-value payments; and 
attract all the principles and their respective key considerations that are applicable to a SIPS, ${ }^{22}$ to ensure that such an arrangement is functioning in a safe and efficient manner.

The oversight unit would be responsible for ensuring that the W-CBDC arrangement is functioning in a safe and efficient manner and would also cover critical service providers. ${ }^{23}$ In addition, where such an arrangement is being operated by the central bank, key considerations in respect of some of the principles would not be applicable. ${ }^{24}$ The oversight unit should also take into account additional guidance provided by CPMI-IOSCO. ${ }^{25}$ The oversight unit/department would also be tasked with the five responsibilities as an overseer of systemically important payment systems (SIPS) listed in the CPMI-IOSCO PFMI report. ${ }^{26}$ To this end it is critical that it cooperates with other regulatory entities both domestically and on a cross-border basis depending on the type of W-CBDC arrangement, for example in payment versus payment $(\mathrm{PvP})$ and delivery versus payment (DvP) arrangements.

It is likely going forward that certain elements could gain criticality in the oversight mandate with regard to W-CBDCs. For instance, these could be greater emphasis on higher operational reliability; greater cyber resilience and cyber security (especially in a DLT platform where there could be no single point of failure but could have multiple vulnerable points for cyberattacks); and interdependencies and linkages with other FMIs.

In summary, the oversight departments of central banks will have to gear themselves to take on this new challenge while adhering in most respects to the time-tested principles of oversight. As in the case of any payment instrument and payment system, the degree of emphasis on various aspects would vary, but the

systems that settle payments used to effect settlement in other systemically important FMIs.' CPSS and IOSCO, Principles for Financial Market Infrastructures, cit., p. 12.

22 Ibid.

23 See Annex F in ibid., p. 170-171.

24 CPSS and IOSCO, 'Application of the Principles for Financial Market Infrastructures to Central Bank FMIs', in CPMI Papers, No. 130 (August 2015), https://www.bis.org/ cpmi/publ/d130.htm.

25 Committee on Payments and Market Infrastructures (CPMI), 'Reducing the Risk of Wholesale Payments Fraud Related to Endpoint Security: A Toolkit', in CPMI Papers, No. 188 (October 2019), https://www.bis.org/cpmi/publ/d188.htm.

26 See Annex A in CPSS and IOSCO, Principles for Financial Market Infrastructures, cit., p. 138-139. 
basic tenets of oversight to ensure safe and efficient operation of financial market infrastructure ${ }^{27}$ would continue to apply and would need to be adhered to.

Some of the other issues that overseers could be confronted with would depend on the type of CBDC arrangement adopted. For instance, this would include the use cases - would a RCBDC arrangement be used only for personto-person payments or for various other use cases such as P2B, B2P, B2B, P2G, G2P, B2G, and G2B. Depending on the use cases, the central bank may have to take a decision on the account holding structure it would adopt and the distribution model for the RCBDC. Another issue is the ease with which users can convert CBDC into commercial bank money and vice versa, and the interlinkages between the two, while at the same time addressing issues of interoperability. Fee structure (if any) would also have to be devised by central banks for CBDC arrangements.

Central banks would have to take into account the likely impact on private sector innovation and competition in the payments arena. Last but not least, central banks should not lose sight of the fact that reskilling their staff would be necessary to effectively carry out the oversight function. A high level of coordination between various central bank departments would also have to be ensured by the managements of the central banks to avoid turf wars.

\section{Annex 1: World Bank practical guide for retail payments stocktaking $^{28}$}

Guideline 1. The overall scope and structure of the stocktaking exercise shall be driven by the high-level public policy goals set forth in the area of retail payments.

Guideline 2. Adequate attention needs to be devoted to the planning and organization of the stocktaking exercise.

Guideline 3. Industry players should be involved from the very early stages.

Guideline 4. Obtaining sufficient, high-quality data and other types of information is at the heart of the stocktaking exercise.

Guideline 5. Devote sufficient time to report preparation and to designing the strategy for the wide dissemination of results.

27 CPSS and IOSCO, Principles for Financial Market Infrastructures, cit.

28 Source: World Bank, Banco Central do Brasil and European Central Bank, A Practical Guide for Retail Payments Stocktaking, cit., p. 4. 


\section{Annex 2: CPMI-IOSCO principles for financial market infrastructures ${ }^{29}$}

\section{General organisation}

Principle 1. Legal basis: Any financial market infrastructure (FMI) should have a well-founded, clear, transparent and enforceable legal basis for each material aspect of its activities in all relevant jurisdictions.

Principle 2. Governance: An FMI should have governance arrangements that are clear and transparent, promote the safety and efficiency of the FMI, and support the stability of the broader financial system, other relevant public interest considerations and the objectives of relevant stakeholders.

Principle 3. Framework for the comprehensive management of risks: An FMI should have a sound risk-management framework for comprehensively managing legal, credit, liquidity, operational and other risks.

\section{Credit and liquidity risk management}

Principle 4. Credit risk: An FMI should effectively measure, monitor and manage its credit exposures to participants and those arising from its payment, clearing and settlement processes. An FMI should maintain sufficient financial resources to cover its credit exposure to each participant fully with a high degree of confidence. In addition, a central counterparty (CCP) that is involved in activities with a more complex risk profile or that is systemically important in multiple jurisdictions should maintain additional financial resources sufficient to cover a wide range of potential stress scenarios that should include, but not be limited to, the default of the two participants and their affiliates that would potentially cause the largest aggregate credit exposure to the CCP in extreme but plausible market conditions. All other CCPs should maintain additional financial resources sufficient to cover a wide range of potential stress scenarios that should include, but not be limited to, the default of the participant and its affiliates that would potentially cause the largest aggregate credit exposure to the CCP in extreme but plausible market conditions.

Principle 5. Collateral: An FMI that requires collateral to manage its or its participants' credit exposure should accept collateral with low credit, liquidity

29 Source: CPSS and IOSCO, Principles for Financial Market Infrastructures, cit., p. 1-4. 
and market risks. An FMI should also set and enforce appropriately conservative haircuts and concentration limits.

Principle 6. Margin: A CCP should cover its credit exposures to its participants for all products through an effective margin system that is risk-based and regularly reviewed.

Principle 7. Liquidity risk: An FMI should effectively measure, monitor, and manage its liquidity risk. An FMI should maintain sufficient liquid resources in all relevant currencies to effect same-day and, where appropriate, intraday and multiday settlement of payment obligations with a high degree of confidence under a wide range of potential stress scenarios that should include, but not be limited to, the default of the participant and its affiliates that would generate the largest aggregate liquidity obligation for the FMI in extreme but plausible market conditions.

\section{Settlement}

Principle 8. Settlement finality: An FMI should provide clear and certain final settlement, at a minimum by the end of the value date. Where necessary or preferable, an FMI should provide final settlement intraday or in real time.

Principle 9. Money settlements: An FMI should conduct its money settlements in central bank money where practical and available. If central bank money is not used, an FMI should minimise and strictly control the credit and liquidity risk arising from the use of commercial bank money.

Principle 10. Physical deliveries: An FMI should clearly state its obligations with respect to the delivery of physical instruments or commodities and should identify, monitor and manage the risks associated with such physical deliveries.

\section{Central securities depositories and exchange-of-value settlement systems}

Principle 11. Central securities depositories: A central securities depository (CSD) should have appropriate rules and procedures to help ensure the integrity of securities issues and minimise and manage the risks associated with the safekeeping and transfer of securities. A CSD should maintain securities in an immobilised or dematerialised form for their transfer by book entry.

Principle 12. Exchange-of-value settlement systems: If an FMI settles transaction that involve the settlement of two linked obligations (for example, securities or foreign exchange transactions), it should eliminate principal risk by 
conditioning the final settlement of one obligation upon the final settlement of the other.

\section{Default management}

Principle 13. Participant-default rules and procedures: An FMI should have effective and clearly defined rules and procedures to manage a participant default. These rules and procedures should be designed to ensure that the FMI can take timely action to contain losses and liquidity pressures and continue to meet its obligations.

Principle 14. Segregation and portability: A CCP should have rules and procedures that enable the segregation and portability of positions of a participant's customers and the collateral provided to the CCP with respect to those positions.

\section{General business and operational risk management}

Principle 15. General business risk: An FMI should identify, monitor and manage its general business risk and hold sufficient liquid net assets funded by equity to cover potential general business losses so that it can continue operations and services as a going concern if those losses materialise. Further, liquid net assets should at all times be sufficient to ensure a recovery or orderly winddown of critical operations and services.

Principle 16. Custody and investment risks: An FMI should safeguard its own and its participants' assets and minimise the risk of loss on and delay in access to these assets. An FMI's investments should be in instruments with minimal credit, market and liquidity risks.

Principle 17. Operational risk: An FMI should identify the plausible sources of operational risk, both internal and external, and mitigate their impact through the use of appropriate systems, policies, procedures and controls. Systems should be designed to ensure a high degree of security and operational reliability, and should have adequate, scalable capacity. Business continuity management should aim for timely recovery of operations and fulfilment of the FMI's obligations, including in the event of a wide-scale or major disruption.

\section{Access}

Principle 18. Access and participation requirements: An FMI should have objective, risk-based and publicly disclosed criteria for participation, which permit fair and open access. 
Principle 19. Tiered participation arrangements: An FMI should identify, monitor and manage the material risks to the FMI arising from tiered participation arrangements.

Principle 20. FMI links: An FMI that establishes a link with one or more FMIs should identify, monitor and manage link-related risks.

\section{Efficiency}

Principle 21. Efficiency and effectiveness: An FMI should be efficient and effective in meeting the requirements of its participants and the markets it serves. Principle 22. Communication procedures and standards: An FMI should use, or at a minimum accommodate, relevant internationally accepted communication procedures and standards in order to facilitate efficient payment, clearing, settlement and recording.

\section{Transparency}

Principle 23. Disclosure of rules, key procedures, and market data: An FMI should have clear and comprehensive rules and procedures and should provide sufficient information to enable participants to have an accurate understanding of the risks, fees and other material costs they incur by participating in the FMI. All relevant rules and key procedures should be publicly disclosed. Principle 24. Disclosure of market data by trade repositories: A trade repository should provide timely and accurate data to relevant authorities and the public in line with their respective needs.

\section{Responsibilities of central banks, market regulators, and other relevant authorities for financial market infrastructures}

Responsibility A. Regulation, supervision, and oversight of FMIs: FMIs should be subject to appropriate and effective regulation, supervision and oversight by a central bank, market regulator or other relevant authority.

Responsibility B. Regulatory, supervisory, and oversight powers and resources: Central banks, market regulators, and other relevant authorities should have the powers and resources to carry out effectively their responsibilities in regulating, supervising and overseeing FMIs.

Responsibility C. Disclosure of objectives and policies with respect to FMIs: Central banks, market regulators and other relevant authorities should clearly define and disclose their regulatory, supervisory and oversight policies with respect to FMIs. 
Responsibility D. Application of principles for FMIs: Central banks, market regulators and other relevant authorities should adopt, where relevant, internationally accepted principles for FMIs and apply them consistently.

Responsibility E. Cooperation with other authorities: Central banks, market regulators, and other relevant authorities should cooperate with each other, both domestically and internationally, as appropriate, in promoting the safety and efficiency of FMIs.

\section{Annex 3: General guidance for NPS development ${ }^{30}$}

\section{A. Banking system}

Guideline 1. Keep the central bank at the centre: due to its overall responsibility for a sound currency, the central bank has a central role in the development of the use of money as an effective means of payment.

Guideline 2. Promote the role of a sound banking system: payment accounts, instruments and services available to end users are provided by banks and other similar financial institutions, which compete individually but often need to act cooperatively as a system.

\section{B. Planning}

Guideline 3. Recognise complexity: planning should be based on a comprehensive understanding of all the core elements of the national payment system and the principal factors influencing its development.

Guideline 4. Focus on needs: identify, and be guided by, the payment needs of all users in the national payment system and by the capabilities of the economy.

Guideline 5. Set clear priorities: plan and prioritise development of the national payment system strategically.

Guideline 6. Implementation is key: ensure effective implementation of the strategic plan.

\section{Institutional framework}

Guideline 7. Promote market development: the expansion and strengthening of market arrangements for payment services are key aspects of the evolution of the national payment system.

30 Source: CPSS, 'General Guidance for Payment System Development', cit., p. 56. 
Guideline 8. Involve relevant stakeholders: encourage the development of effective consultation among relevant stakeholders in the national payment system.

Guideline 9. Collaborate for effective oversight: effective payment system oversight by the central bank often requires collaborative arrangements with other authorities.

Guideline 10. Promote legal certainty: develop a transparent, comprehensive and sound legal framework for the national payment system.

\section{Infrastructure}

Guideline 11. Expand availability of retail payment services: extend the availability and choice of efficient and secure non-cash payment instruments and services available to consumers, businesses and government by expanding and improving retail payment infrastructures.

Guideline 12. Let the business case guide the large-value payment system: develop a largevalue payment system based primarily on the needs of financial markets and the growth in time-critical interbank payments.

Guideline 13. Align development of payment and securities systems: coordinate the development of securities and large-value payment systems for safety and efficiency in the financial system.

Guideline 14. Coordinate settlement of retail, large-value and securities systems: the settlement processes for the core systems should be operationally coordinated to efficiently manage the interrelated liquidity needs and settlement risks among them.

\section{Annex 4: World Bank guidelines for government payment programs (GPS) ${ }^{31}$}

The General Guidelines aim at the following public policy goals for GPS: Payments and collections made as part of existing or new GPS should support the sound, efficient and transparent management of public financial resources. GPS should therefore be safe, reliable, and cost-effective. In addition, efforts to modernize GPS should be leveraged to accelerate the development of the national payments system more broadly, and to promote financial inclusion.

31 Source: World Bank, General Guidelines for the Development of Government Payment Programs, cit. 


\section{A. Governance, safety and efficiency}

Guideline 1. Ensure proper program governance and risk management: governance arrangements should ensure accountability, transparency, and effectiveness in managing the risks associated with GPS.

Guideline 2. Review and streamline treasury processes, then work on their automation: the treasury should devote extensive efforts to identifying all relevant needs with regard to improved safety, efficiency and transparency.

Guideline 3. Take full advantage of electronic payment methods: the extensive use of electronic payments in GPS can reduce costs and improve transparency and traceability.

Guideline 4. Create appropriate organizational arrangements to foster the continuous development of GPS: the national treasury/ministry of finance should consider engaging in collaborative schemes with the central bank and other stakeholders to identify additional improvement opportunities for these programs and, eventually, facilitate their implementation.

\section{B. Legal and regulatory}

Guideline 5. An appropriate legal framework with specific applicability to GPS can further underpin their safe and efficient operation: laws and/or regulations that provide clarity and certainty to the various parties involved, and that promote effectiveness and transparency in the execution of programs should be enacted/approved.

Guideline 6: Laws and regulations on payment instruments and systems, competition and consumer protection can also have an important bearing on GPS: the legal basis should support sound and fair practices in the market place, and be flexible enough to accommodate innovations.

\section{Payment systems infrastructure}

Guideline 7. An appropriate payments infrastructure should be in place: the potential to obtain substantial benefits from migrating government expenditures and collections to electronic payments relies on there being the required payments infrastructures to process such payments safely, efficiently and at a reasonable cost.

Guideline 8. Maximize the potential of the available infrastructures through interoperability and widespread usage: payment service providers being able to channel their payment operations through any of the key mainstream 
infrastructures promotes efficiency, network expansion, and a level playing field for all players.

\section{Cooperation and partnerships to leverage GPS}

Guideline 9. Adopt a strategic approach to the development of GPS: the reforming of GPS has the potential to trigger the development of a robust payments infrastructure, which in turn will support the safe and efficient processing of government payments.

Guideline 10. Leverage on GPS to promote financial inclusion: the large volume of payments issued by governments, as well as the nature of some specific programs like social spending programs, represents an opportunity to promote or facilitate financial inclusion on a large scale.

\section{Annex 5: CBDC and payment services during emergencies ${ }^{32}$}

In cases of national emergencies, $\mathrm{CBDC}$ may play a special role. In emergencies, governments need to find ways of getting money to people on the margins of society and facilitate their payments activity. Yet, as experience worldwide is painfully showing at the time of writing this note, during the COVID-19 pandemic, public authorities may be encountering significant challenges in getting funds to those in need and enabling access to money. Often, the complexity of public funding programmes slows down the speed at which businesses and citizens receive the money to sustain themselves and raises uncertainty as to whether and when the money will actually be made available. In various countries, small and medium size enterprises have expressed concerns that delivery of measures is taking too long. ${ }^{33}$ Failure to address these challenges aggravates the macroeconomic effects of the crisis and diminishes people's ability to weather them, increasing their frustration. Their persistence might breed exasperation and foment social upheaval. The pandemic will probably accelerate

32 Prepared by Biagio Bossone and Harish Natarajan (World Bank). In particular, this annex draws on Biagio Bossone and Harish Natarajan, 'Getting Funds to Those in Need and Enabling Access to Money during COVID-19, Part 3: Central Bank Digital Currencies and Other Instruments', in VoxEU, 15 July 2020, https://voxeu.org/node/ 65987.

33 See, for instance, Organisation for Economic Co-operation and Development (OECD), Coronavirus (COVID-19): SME Policy Responses, Paris, OECD, updated July 2020, https://www.oecd.org/coronavirus/policy-responses/coronavirus-covid19-sme-policy-responses-04440101. 
CBDC developments (the 'digital dollar' discussed below is an example), even by clearing the political way toward its introduction, and may amplify calls to defend the role of CBDCs.

In the context of crises such as the COVID-19 pandemic, CBDC could greatly assist in delivering funds to the greatest bulk of the population in need. Particularly during emergencies, a central bank could agree to act as government agent and execute CBDC fund transfers on the government's behalf to individuals and businesses that the government identifies as being in need of financial support. Through CBDC, governments could send direct payments much more rapidly than through checks or tax refunds and could provide geographically and temporally targeted relief. The CBDC supporting infrastructure would also enable fund receivers to make payments and transfers seamlessly to other CBDC holders and/or non-CBDC holders, anywhere and anytime across the economy. In addition, CBDC could reinforce the resilience of a country's retail payment services, especially in cases where private sector infrastructures are disrupted due to, say, technical problems, personnel unavailability or inability of service providers to operate. Finally, CBDC would serve as a substitute for cash and in-person payment methods when social distancing is required or when the use of cash plummets as people are increasingly wary of engaging with potentially germ-infested surfaces.

During crises, CBDC could be used as a payment conduit for delivering stimulus packages to households and businesses. This would be especially useful when businesses risk closing because they run out of money, and people lose their jobs or become ill and also run out of money. An example is the recent proposal for a US House of Representatives emergency COVID-19 stimulus bill, which referred to creating a: digital dollar" to get stimulus payments to unbanked Americans. In practice, the US Treasury would make payments through direct deposits to recipient accounts (FedAccounts) held at Federal Reserve Banks (FRBs) or FRB-member banks through pass-through FedAccounts. The proposal was ultimately pulled from the final legislation, but is now the subject of a dedicated Senate draft bill.

A relevant consideration to be made between using CBDC for aggregate demand stimulus or for giving emergency cash to distressed households and businesses. If the primary purpose of cash transfers is to raise aggregate demand, it is not critically important if some people don't get the money. What matters is that CBDC reaches a majority of people and businesses that spend the money and stimulate demand. On the other hand, however, if the primary purpose is to relieve hardship, then it matters if the money doesn't 
reach the right people and enterprises, since hardship would not be effectively relieved and the scheme would be seen as unfair. Failures in this area might put central banks at reputational and political risks. Thus, if CBDC were to be used for relief purposes, a perimeter of responsibilities should be set establishing with clarity that the central bank acts as the agent of government and only executes government instructions. The central bank should not get involved in discussions as to whom or which entities should be entitled to receive money (except in so far as restricting the distribution of money would affect its own mandate).

\section{Annex 6: World Bank guidance on developing a comprehensive retail payments strategy ${ }^{34}$}

Guideline 1: The market for retail payments should be transparent, have adequate protection of payers and payees interests, and be cost-effective.

Guideline 2: Retail payments require reliable underlying financial, communications and other types of infrastructure; these infrastructures should be put in place to increase the efficiency of retail payments. These infrastructures include an inter-bank electronic funds transfer system, an inter-bank card payment platform, credit reporting platforms, data sharing platforms, large value inter-bank gross settlement systems, availability of robust communications infrastructure and also a national identification infrastructure.

Guideline 3: Retail payments should be supported by a sound, predictable, nondiscriminatory, and proportionate legal and regulatory framework.

Guideline 4: Competitive market conditions should be fostered in the retail payments industry, with an appropriate balance between co-operation and competition to foster, among other things, the proper level of interoperability in the retail payment infrastructure.

Guideline 5: Retail payments should be supported by appropriate governance and risk management practices.

Guideline 6: Public authorities should exercise effective oversight over the retail payments market and consider proactive interventions where appropriate.

34 Source: Massimo Cirasino and Jose Antonio Garcia (eds), Developing a Comprehensive National Retail Payments Strategy, cit., p. x. 


\section{Annex 7: World Bank guidelines on balancing cooperation and competition $^{35}$}

Guideline 1: Market complexities need to be recognized and analyzed in detail before any action is decided and implemented. Environmental, legal and legacy factors, and governance of the infrastructure has a significant impact on cooperation/competition. Gaining access to messaging, clearing and settlement services is of capital importance for new entrants in the market.

Guideline 2: Policy trade-offs are relevant in this domain. Therefore, policy priorities will have to be determined and the type of public intervention should depend on the main public objective(s) pursued. Public policy objectives in retail payments systems are multiple. The justification for intervention depends upon the main public policy objective(s) pursued and evidence of perceived market failure; ex-ante, transparent determination of policy objectives is desirable.

Guideline 3: Effective oversight of retail payment systems by the central bank is crucial to balance cooperation and competition issues. Effective oversight is the main tool to achieve an appropriate balance between cooperation and competition, central banks being the 'natural' PS overseers in cooperation with other authorities. PS oversight function scope should be broad/flexible enough to cover new instruments/players.

Guideline 4: Institutional mechanisms to promote cooperation and information sharing are essential. Fragmentation of relevant policymakers and scope of their mandates may be an issue; authorities' cooperation frameworks to be strengthened/broadened; payment councils, industry associations groups and similar bodies to be leveraged.

\section{Annex 8: The CPSS-World Bank general principles for international remittance services ${ }^{36}$}

General principle 1: Transparency and consumer protection: The market for remittance services should be transparent and have adequate consumer protection.

35 Based on: Massimo Cirasino and Jose Antonio Garcia (eds), Developing a Comprehensive National Retail Payments Strategy, cit., p. 55-56.

36 Source: CPSS and World Bank, 'General Principles for International Remittance Services', cit., p. 4. 
General principle 2: Payment systems infrastructure: Improvements to payment system infrastructure that have the potential to increase the efficiency of remittance services should be encouraged.

General principle 3: Legal and regulatory framework: Remittance services should be supported by a sound, predictable, non-discriminatory, and proportionate legal and regulatory framework in relevant jurisdictions.

General principle 4: Market structure and competition: Competitive market conditions, including appropriate access to domestic payments infrastructures, should be fostered in the remittance industry.

General principle 5: Governance and risk management: Remittance services should be supported by appropriate governance and risk management practices.

Roles of remittance service providers and public authorities: (a) Remittance service providers should participate actively in the implementation of the general principles. (b) Public authorities should evaluate what actions to take to achieve the public policy objectives through the implementation of the general principles.

\section{Annex 9: World Bank guidelines for successful integration of regional financial infrastructures ${ }^{37}$}

The WB-led G25 Experts Group drafted guidelines to provide high-level guidance to principal policymakers and stakeholders in the development of regional or cross-regional integration of financial infrastructures. The 19 guidelines belong to the following categories:

Enabling and institutional guidelines: Outline the set of institutional arrangements that enable a regional financial infrastructure integration proposal to move forward from its preliminary vision to an actual operational arrangement in an effective fashion.

Planning guidelines: The basis for determining if regional financial infrastructure integration is necessary and justifiable for the stakeholders in the region at that particular time. This is the 'make or break' stage at which regional FI integration initiatives either move forward or are postponed.

37 Source: World Bank, Guidelines for the Successful Regional Integration of Financial Infrastructures, cit. 
Design guidelines and implementation guidelines: Deal with the heart of the regional financial infrastructure integration programme. It is at these stages of the integration initiative that leadership, commitment, consultation and effective management become most crucial.

Sustainability guidelines: Help establish a strategic direction and sound business culture for the regional FI arrangement that, together with the continuous oversight from public sector authorities, will help ensure that it will continue to evolve and develop to meet future stakeholder needs, legal and regulatory requirements, and policy standards affecting its operations, and will do so in a transparent and credible fashion.

\section{References}

Codruta Boar, Henry Holden and Amber Wadsworth, 'Impending Arrival A Sequel to the Survey on Central Bank Digital Currency', in BIS Papers, No. 107 (January 2020), https://www.bis.org/publ/bppdf/bispap107.htm

Biagio Bossone and Massimo Cirasino, 'The Oversight of the Payments Systems: A Framework for the Development and Governance of Payment Systems in Emerging Economies', in Western Hemisphere Payments and Securities Clearance and Settlement Systems Research Series, No. 1 (July 2001), http://documents.worldbank.org/curated/en/646651468156578578

Biagio Bossone and Harish Natarajan, 'Getting Funds to Those in Need and Enabling Access to Money during COVID-19, Part 3: Central Bank Digital Currencies and Other Instruments', in VoxEU, 15 July 2020, https://voxeu. org/node/65987

Massimo Cirasino and Jose Antonio Garcia (eds), Developing a Comprehensive National Retail Payments Strategy, Washington, World Bank, 2012, http:// documents.worldbank.org/curated/en/839121469729131991

Committee on Payment and Settlement Systems (CPSS), 'Central Bank Oversight of Payment and Settlement Systems', in CPMI Papers, No. 68 (May 2005), https://www.bis.org/cpmi/publ/d68.htm

Committee on Payment and Settlement Systems (CPSS), 'General Guidance for Payment System Development', in CPMI Papers, No 70 (January 2006), https://www.bis.org/cpmi/publ/d70.htm

Committee on Payment and Settlement Systems (CPSS) and International Organization of Securities Commissions (IOSCO), 'Application of the Principles for Financial Market Infrastructures to Central Bank FMIs', in CPMI Papers, No. 130 (August 2015), https://www.bis.org/cpmi/publ/d130. htm 
Committee on Payment and Settlement Systems (CPSS) and International Organization of Securities Commissions (IOSCO), Principles for Financial Market Infrastructures, Basel, Bank for International Settlements, April 2012, https://www.bis.org/cpmi/publ/d101a.htm

Committee on Payment and Settlement Systems (CPSS) and World Bank, 'General Principles for International Remittance Services', in CPMI Papers, No. 76 (January 2007), https://www.bis.org/cpmi/publ/d76.htm

Committee on Payments and Market Infrastructures (CPMI), 'Reducing the Risk of Wholesale Payments Fraud Related to Endpoint Security: A Toolkit', in CPMI Papers, No. 188 (October 2019), https://www.bis.org/cpmi/publ/ d188.htm

Committee on Payments and Market Infrastructures (CPMI) and World Bank, 'Payment Aspects of Financial Inclusion', in CPMI Papers, No. 144 (April 2016), https://www.bis.org/cpmi/publ/d144.htm;

Committee on Payments and Market Infrastructures (CPMI) and World Bank, 'Payment Aspects of Financial Inclusion in the Fintech Era', in CPMI Papers, No. 191 (April 2020), https://www.bis.org/cpmi/publ/d191.htm

European Central Bank (ECB), Oversight Framework for Card Payment Schemes - Standards, January 2008, https://www.ecb.europa.eu/pub/pdf/ other/oversightfwcardpaymentsss200801en.pdf

Financial Stability Board (FSB), Enhancing Cross-border Payments. Stage 1 Report to the G20: Technical Background Report, 9 April 2020, https://www. fsb.org/wp-content/uploads/P090420-2.pdf

Bruce J. Summers (ed.), Payment Systems: Design, Governance and Oversight, London, Central Banking Publications, 2012

Bruce J. Summers, 'Payment System Design and Public Policy', in Bruce J. Summers (ed.), Payment Systems: Design, Governance and Oversight, London, Central Banking Publications, 2012, p. 3-16

Organisation for Economic Co-operation and Development (OECD), Coronavirus (COVID-19): SME Policy Responses, Paris, OECD, updated July 2020, https://www.oecd.org/coronavirus/policy-responses/ coronavirus-covid-19-sme-policy-responses-04440101

World Bank, General Guidelines for the Development of Government Payment Programs, Washington, World Bank, 2012, http://hdl.handle.net/10986/ 22127

World Bank, Guidelines for the Successful Regional Integration of Financial Infrastructures, Washington, World Bank, 2014, http://hdl.handle.net/10986/ 22110 
World Bank, Retail Payments. A Practical Guide for Measuring Retail Payment Costs, Washington, World Bank, November 2016, http://hdl.handle.net/ 10986/25861

World Bank, Banco Central do Brasil and European Central Bank, A Practical Guide for Retail Payments Stocktaking, Washington, World Bank, 2012, https://web.worldbank.org/archive/website01530/WEB/IMAGES/WB_ 2012_.PDF

World Bank and Bank of Albania, The Retail Payment Costs and Savings in Albania, Washington, World Bank, June 2018, http://hdl.handle.net/10986/ 30060 


\section{Robleh Ali \\ Chapter 3: Central Bank Digital Currency and the Future Financial System}

Central bank digital currency (CBDC) creates the opportunity to build the foundation of a new financial system that is more secure, less risky and more efficient than the current system. In this chapter we look at three basic functions of the financial system - payments, payment versus payment $(\mathrm{PvP})$ and delivery versus payment (DvP) - to show how CBDC could alter the structure of the financial system by reshaping the underlying technology.

This chapter has four parts: first it describes how these three functions (payments, $\mathrm{PvP}$ and $\mathrm{DvP}$ ) work in the existing system; then it looks at what we can learn from existing digital currencies about how these transactions can be done differently; third, it addresses CBDC design; and finally it examines how this could improve the structure of the financial system.

In this chapter, we adopt the common definition of a CBDC: a universally available, direct liability of the central bank, with the core infrastructure operated by the central bank itself and user-facing services operated by private-sector providers. ${ }^{1}$

\subsection{The existing financial system}

The financial system has three main goals: 1) financing productive enterprises, households and governments while providing returns to investors; 2) insuring against risk; 3) making payments.

The financial system as presently constituted is comprised of institutions, rules and software. All these elements play a role in making the system function, but the mechanism for enforcement varies. In some cases, the rules of the system are enforced by contract, with the software merely recording data. In others. the

1 For more discussion of CBDC definitions and structures, see Bank of England, Central Bank Digital Currency. Opportunities, Challenges and Design, Discussion Paper, March 2020, https://www.bankofengland.co.uk/paper/2020/central-bank-digital-currencyopportunities-challenges-and-design-discussion-paper; and Raphael Auer and Rainer Boehme, 'The Technology of Retail Central Bank Digital Currency', in BIS Quarterly Review, March 2020, p. 85-100, https://www.bis.org/publ/qtrpdf/r_qt2003j.htm. 
software itself is part of the enforcement mechanism - for example in determining the format of how data is exchanged in the system. Ultimately laws and institutions lie at the root of the system, and any ability the software has to enforce rules is derived from them.

The rules of the existing system are drawn from different sources - contracts and legislation. This combination of private and public law defines the obligations between the different institutions in the system, as well as creating the institutions themselves. Pistor describes these laws as a toolkit: 'Their toolkit consists of the modules of the code: the rules of property and collateral law, the principles of trust, corporate, and bankruptcy law; and contract law; the most malleable of them all.'2

This characterization is useful because it demonstrates the parallel between software and law when thinking about the financial system. Both are a set of rules with a method of enforcement; larger bespoke systems are constructed from smaller standard modules; and both are created by expert practitioners. The difference is in how the rules are translated into a functioning system.

\section{Retail payments}

There are many different types of payment system, both wholesale and retail, but from an institutional perspective they work in a similar way, with a centralised system operator setting the rules and managing the participants, both users and members.

In any payment system there are different types of participant. For example, in a retail card system, in addition to the payment system operator there are banks, merchants and the end users.

All the relationships in the system are defined by contracts. The members have an agreement with the payment system provider setting out the rules by which they must abide. In turn, the members have contracts with the end users and the merchants that establish the terms upon which they can use the system.

From a technology perspective, the members can use different software for their own internal systems, because a retail network is overlaid on top of an existing set of bank accounts that operate independently. The payment system provider does have to establish certain technical standards for how the common

2 Katharina Pistor, The Code of Capital. How the Law Creates Wealth and Inequality, Princeton/Oxford, Princeton University Press, 2019, p. 160. 


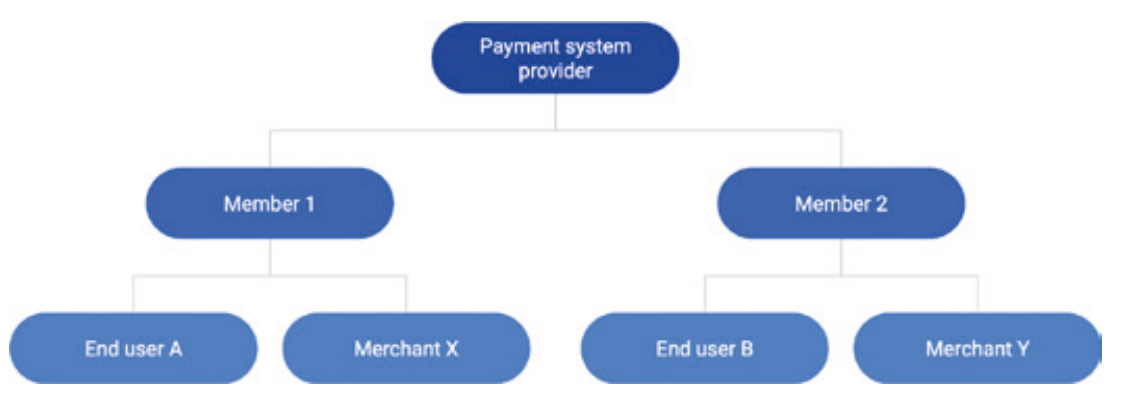

Figure 3.1: Retail payment system structure.

software and hardware in the system function, for example messaging standards and contactless payments. ${ }^{3}$

The technical standards are an interesting aspect of the system, as they demonstrate how software is used to enforce the rules even in the current system. This shows that software is not merely incidental to the functioning of the existing financial system, but can be considered intrinsic to it.

For example, messages in the system have to conform to the format set out in the technical standards. The standards themselves are part of the legal agreement to which the members agree when they join the system. However the primary method of enforcement of the standards on message format is not through the legal agreement, but through the software itself.

If a message is incorrectly formatted, it will be rejected by the system directly and the payment will not work. This is, in a sense, a method of enforcement. The rules are set in the technical standards and they are enforced primarily by the software.

\section{Foreign exchange settlement - PvP}

Settlement risk in foreign exchange transactions occurs when one party to the transaction has to send one currency before receiving the other. The most famous example of this risk materialising is from 1974, when Herstatt Bank in what was then West Germany went bankrupt. Payments to counterparties failed because

3 See Visa contactless payments technical standards: Visa website: Technology Specifications, https://technologypartner.visa.com/Library/Specifications.aspx\# Contactless. 


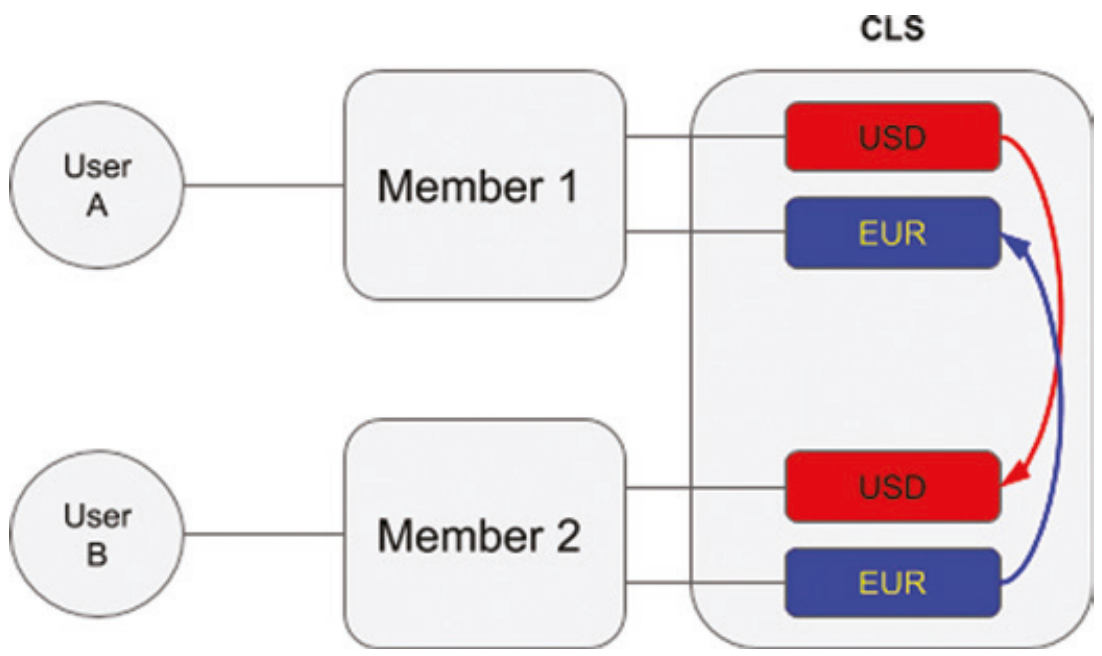

Figure 3.2: Foreign exchange settlement.

of Herstatt's insolvency between when the Deutschmarks were received in the European morning and when the US dollars were due to be paid in New York.

The solution to this problem is $\mathrm{PvP}$. This process ensures that both payments have to be received from the counterparties before either can be paid. In the existing financial system this function is performed by an institution called CLS. ${ }^{4}$

CLS works by maintaining reserve accounts at the central banks of issue for 18 currencies. Members hold accounts at CLS and it ensures that when two currencies are swapped, both members have the funds to complete the transactions. This setup ensures that so-called Herstatt risk is eliminated as, unlike a normal bank, CLS does not have any other business that could incur losses capable of causing insolvency and the use of central bank money for CLS accounts minimises credit risk for money held there.

Figure 3.2 shows a simplified example of how CLS foreign exchange settlement works. In this case, User A and User B wish to settle a US dollar/euro transaction using CLS. They do so via their banks, Member 1 and Member 2, which are both direct members of CLS. CLS has several members that offer settlement services to their customers, and in fact there may be a longer chain of intermediation that shown in figure 3.2.

4 Official website: https://www.cls-group.com. 
Both the euros and US dollars are held at CLS in credit-risk free reserve accounts at the central bank of issue, and neither of the payments can move until the money is in the CLS account. This eliminates the risk of one leg of the transaction happening before the other and the intermediating entity failing before paying out to the end users.

This is the institutional method of eliminating risk, essentially creating a lowrisk, trusted third party that can accept custody of both assets - currencies in the case of CLS - and only swap them when both have been received.

\section{Existing securities settlement $-D v P$}

Securities settlement or DvP works much like PvP in foreign exchange. The challenge is the same - two digital assets that need to be swapped simultaneously - and the solution is similar.

Securities settlement sits at the heart of market-based finance. Central securities depositories (CSDs) store records of both shares and bonds. When a share or a bond is traded, the essence of the transaction is swapping an agreed amount of money for a specified number of securities.

Now that the financial system is completely digitised, the challenge for those trading securities is to ensure that the money and the asset are exchanged simultaneously. If there were only two participants, someone would have to go first, creating the risk that the counterparty would receive the money but not send the securities.

In the existing financial system, this problem has an institutional solution - the CSD. In essence, the CSD stands between sellers and buyers, holding cash and securities and only swapping them when both have been received. As with CLS, end users do not interact directly with the CSD, but through CSD members that provide access to these services. CSD members are normally large financial institutions, and CSD end users are non-financial firms and individuals.

In the example illustrated in Figure 3.3, User A and User B are settling a securities trade. In this case, they access the CSD via their banks, which are direct members of the CSD. Once the trade has been agreed to, the CSD executes the transaction. As with CLS, this is a simplified example as there can be longer chains of intermediation between the end users and CSD members. Also, any securities trade is likely to include an exchange but this part of the process has also been omitted for simplicity.

Systemically important financial market infrastructures (FMIs) such as CLS and CSDs are governed by the Principles for Financial Market Infrastructures (PFMIs), ${ }^{5}$ issued by the Committee on Payments and Market

5 Committee on Payment and Settlement Systems, 'Principles for Financial Market Infrastructures', in CPMI Papers, No. 101 (April 2012), https://www.bis.org/cpmi/publ/ d101.htm. 


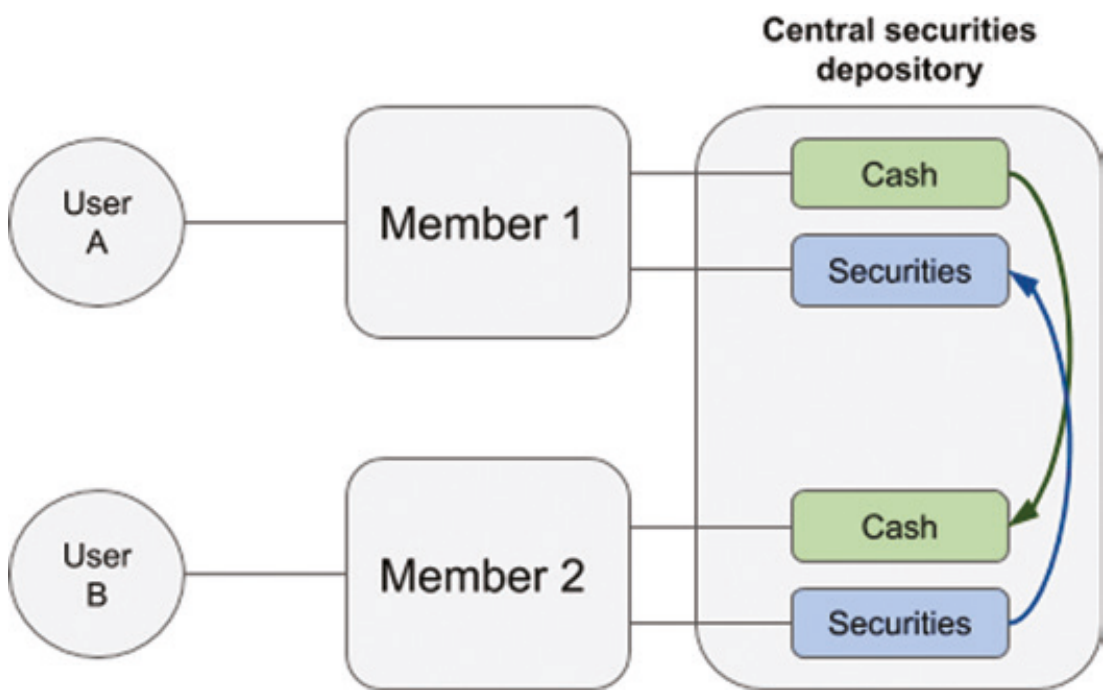

Figure 3.3: Securities settlement.

Infrastructures. ${ }^{6}$ Principle 9 requires FMIs to settle transactions in central bank money where practical and available. As CSDs hold the master record of the securities being traded and have access to central bank money, it means that both legs of the transaction can be settled with minimum risk to the end users.

\subsection{Digital currencies}

The original purpose of Bitcoin was simple - digital payments without institutions. The first sentence in its whitepaper describes it as 'a purely peerto-peer version of electronic cash [that] would allow online payments to be sent directly from one party to another without going through a financial institution.7 Understanding this point is key to understanding the impact of digital currencies on the financial system. It is about a rebalancing between institutions and software.

6 See BIS website: CPMI - Overview, https://www.bis.org/cpmi/about/overview.htm.

7 Satoshi Nakamoto, Bitcoin: A Peer-to-Peer Electronic Cash System, March 2009, p. 1, https://bitcoin.org/en/bitcoin-paper. 
Digital currencies like Bitcoin are fundamentally different in that the rules of the system are intrinsic to the software and enforcement is carried out by machines running the software - it does not rely on any external rules, or on legal agreements or institutions to enforce them.

Another significant change introduced by digital currencies is programmability. Until Bitcoin emerged, payment systems had a single instruction - send amount $\mathrm{X}$ from $\mathrm{A}$ to $\mathrm{B}$. There are two ways of thinking about this change. One is to say that existing payment systems had no programmability and that Bitcoin introduced the entire concept. The other view is to consider the command 'send amount $\mathrm{X}$ from A to B' a very simple form of programmability, in which the only variables are the amount, sender and recipient.

The latter view is probably closer to reality, as most payments in existing payment systems are executed end-to-end by computers, and, in this narrow sense, are akin to Bitcoin transactions - the difference being the institutional architecture surrounding the technology.

\section{Transactions}

Bitcoin transactions are structured around inputs and outputs. The inputs are the outputs from earlier transactions that have not yet been spent - so called unspent transaction outputs (UTXOs) and the outputs are the addresses that will control the bitcoin in the transaction once it has been processed.

Within the inputs and outputs of the transaction is further information: data that satisfies requirements of the input's restriction is added to the input, and new requirements are added to the output. The examples below will describe the types of digital signatures and preimages that are commonly used to restrict outputs. This locking and unlocking process is key to understanding how programmability in Bitcoin works and how it could work for a CBDC.

In this chapter, we will look at three elements of Bitcoin programmability signature locks, timelocks and hashlocks - that can be used to implement DvP and $\mathrm{PvP}$ in a way that shifts enforcement to the software.

\section{Signature locks}

The signature lock implements the instruction 'send amount X from A to B' essentially replicating the basic function of existing payment systems.

Bitcoin transactions do not require a signature lock. If you have bitcoin in your wallet it is perfectly possible to create an output without a signature lock and submit it to the network. This means anyone who sees the output can claim it - in essence the transaction takes the form 'send amount X from A to anyone.' 


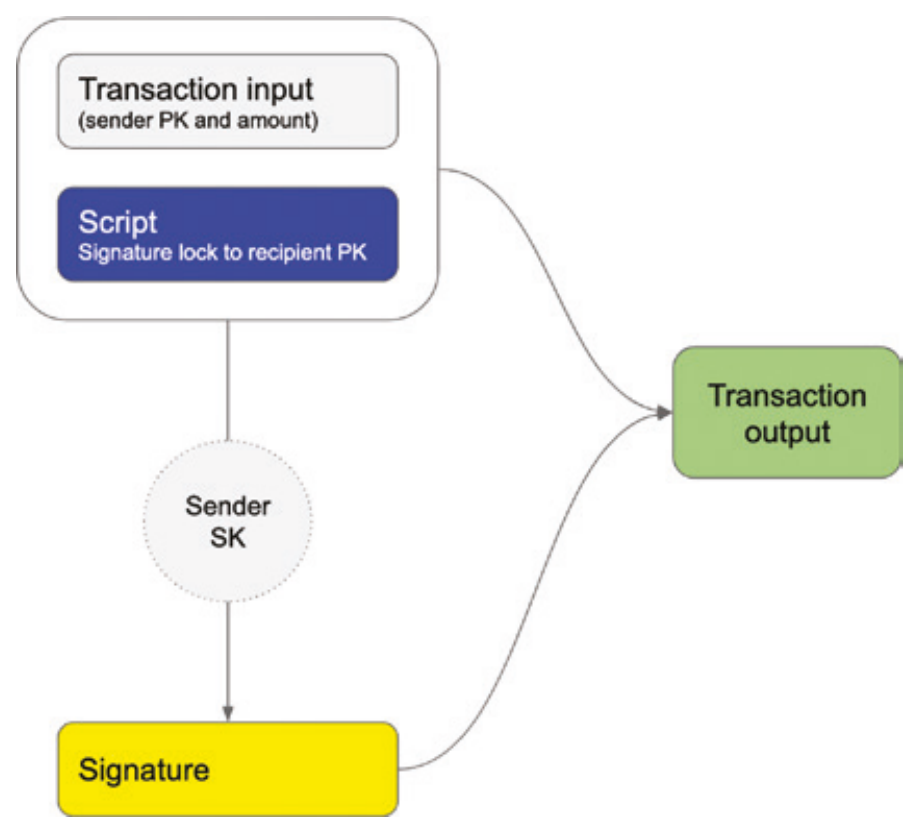

Figure 3.4: Constructing a transaction.

As this type of transaction is not particularly useful, the vast majority of bitcoin transactions use signature locks.

Signature locks use public key cryptography to create and verify signatures. Public key cryptography works by creating a keypair - the secret key (SK) and the public key (PK) that is derived from it. This is a one-way function; the PK is easily derived from the SK but it is computationally infeasible to derive the SK from the PK.

The SK is created by the sender and kept secret - as the name suggests - so it can be used to create signatures that, when combined with the PK, allow anyone to verify that the signature and message were created using the corresponding SK.

The PK is made available to the network with the transaction input to verify the signature. The SK is applied to the transaction to create the digital signature that will be submitted to the network with the transaction. This demonstrates that the user who created the transaction has the authority to spend the coins in the transaction input.

Figure 3.4 shows how the transaction is assembled. The first element is the transaction input which is the amount to be spent in the transaction and the 


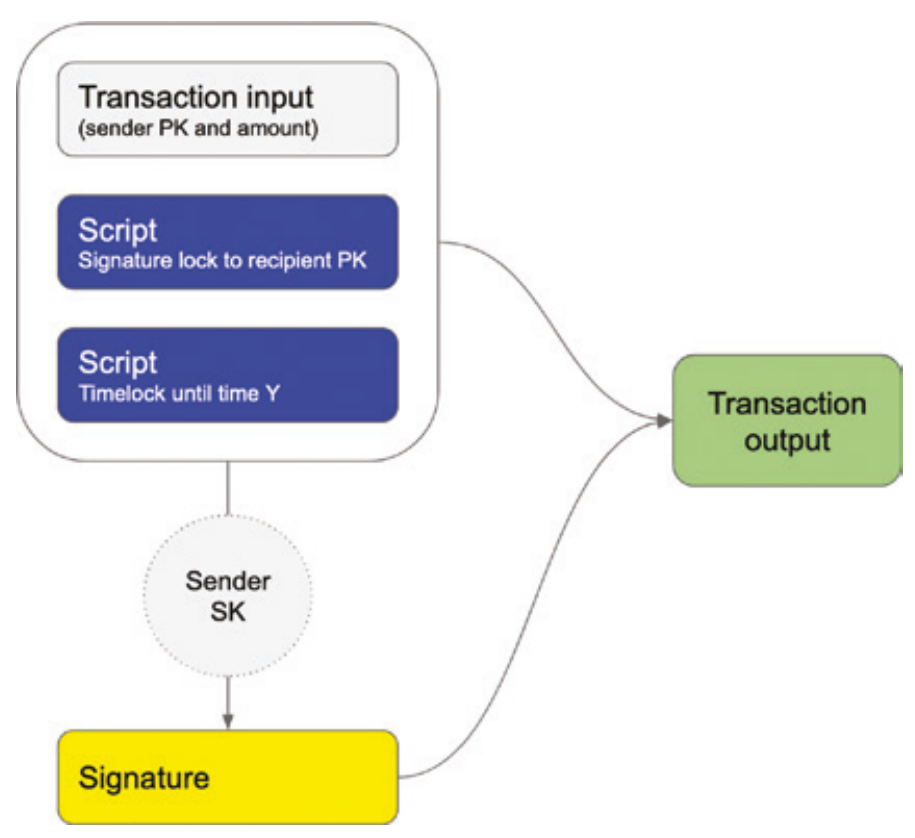

Figure 3.5: Adding a timelock.

corresponding public key. The second element is the script, in this case a signature lock for the PK to which the money is being sent. The SK is then applied to these elements to create the third element, the signature. These three elements are then combined into a transaction, which can be submitted to the network.

For the sake of simplicity, figure 3.4 shows a single input and output. In reality there would likely be multiple inputs and outputs for each transaction.

\section{Timelocks}

Adding a timelock to a transaction allows payments to take the format 'send amount $\mathrm{X}$ from $\mathrm{A}$ to $\mathrm{B}$ not before time Y'. Implementing this requires an additional script to be added to the transaction alongside the signature lock.

Figure 3.5 shows the transaction with a timelock added. The effect of adding the timelock script is to delay the transaction. Delaying a payment until an agreed time is useful by itself, but when combined with a hashlock - described in the next section - it is an important element of implementing DvP and PvP using digital currencies. 
There are also relative and absolute timelocks. An absolute timelock specifies a certain date after which the timelock expires and a relative timelock specifies a certain amount of elapsed time after the transaction (e.g., 7 days) after which the transaction can be spent. These are sometimes interchangeable, but both are needed and used in lightning transactions and the difference is important.

\section{Hashlocks}

Hashlocks allow us to implement the function 'send amount X from A to B if they know preimage $Z$.' At first sight this function may not appear to have a great deal of utility but when combined with timelocks and signature locks it is an important element of making PvP and DvP function.

Hash functions are at the core of hashlocks. A hash function takes an input of arbitrary length and produces a fixed-length output. This is a one-way function in that it is easy to calculate the hash from the input but computationally infeasible to calculate the message from the hash.

Figure 3.6 demonstrates the process using the SHA-256 hash function. The input, 'hello' in this case - commonly known as the preimage - is entered into the hash function and produces the hash ' $2 \mathrm{cf}$... 824'. The same preimage will always produce the same hash and even a tiny change in the preimage will produce a completely different hash.

The application of hash functions to hashlocks allow transactions to be set up which require both a digital signature and knowledge of a secret. In Figure 3.7 above, the hashlock uses the hash of the secret $Z$ and can only be spent when the recipient has $\mathrm{Z}$ revealed to them.

The purpose of doing so is to understand the degree of programmability required to replicate useful functions of the existing financial system. This will help us to assess the degree of functionality that is desirable in a CBDC and the implications for the structure of the financial system.

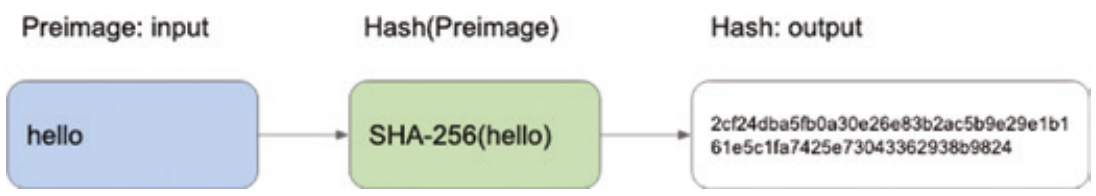

Figure 3.6: Hash function. 


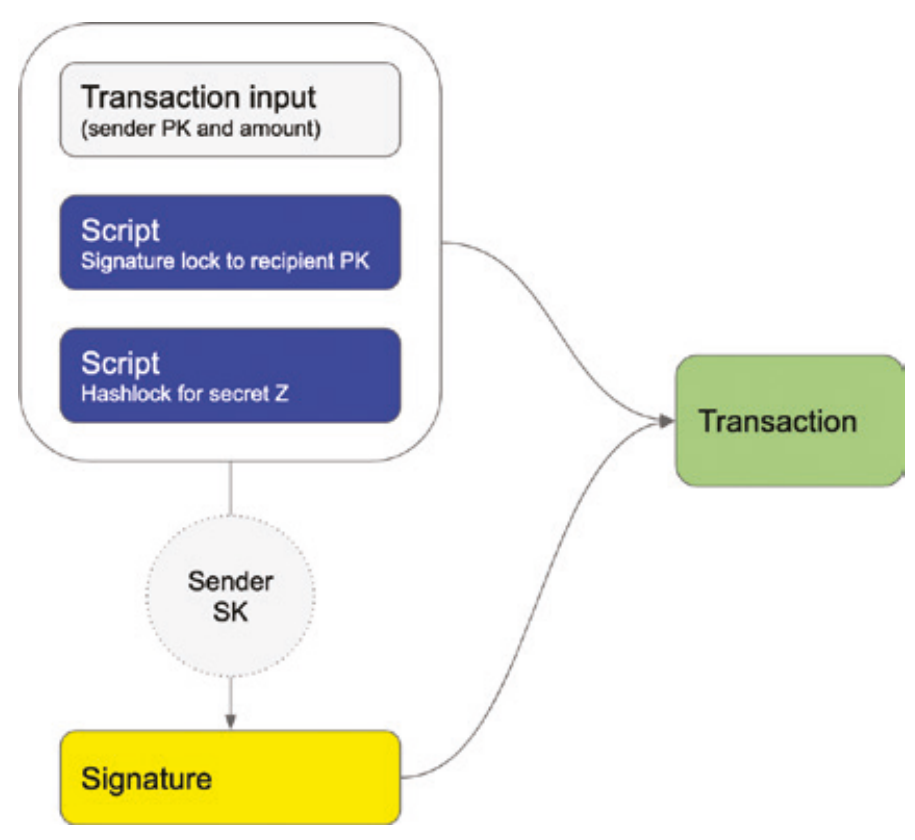

Figure 3.7: Hashlock.

\section{Digital currency generations}

From the release of the Bitcoin whitepaper in late 2008 to 2020, there have been two distinct generations of digital currency platforms. Bitcoin and other digital currencies cloned from its code represent the first generation. Two design choices characterise Bitcoin, one is that the scripting language is deliberately simple and is not Turing complete. That is to say that it cannot be used to perform any arbitrary calculation - for example, there is no loop function in Bitcoin script. The second design choice is that Bitcoin is difficult to change so adding this functionality is very unlikely.

The difficulty of significantly altering Bitcoin led to the second generation of digital currencies led by those who wanted to experiment with a broader feature set than would exist in Bitcoin. One notable example from the second generation is Ethereum, which includes a programming language which is much more expressive than Bitcoin, including Turing completeness. The result is that Ethereum smart contracts can have much greater functionality, although this complexity comes with a cost - more can go wrong. 
In any software system there is an essential trade-off between functionality and security. The more functionality, the greater the chance the developer of the system makes a mistake. These mistakes weaken the system in two ways. One is that a bug in a smart contract can cause significant losses and undermine trust in the system as a whole because of a mistake made in the code. Adding complexity to the system makes it increasingly difficult for programmers to predict all the possible behaviours of a piece of code and avoid writing something that causes a problem.

The other is deliberate attack. Mistakes may not cause the system to spontaneously fail, but could create a vulnerability that an attacker can exploit. Digital currencies are a prime target for these types of attack because they are money and the incentive has risen with their value since Bitcoin first emerged more than a decade ago.

The question is what can be learned from the first two generations of digital currencies when designing the third generation of digital currencies - CBDC.

\subsection{CBDC - The foundation of the new financial system}

CBDC will form the foundation of a new financial system. Its design will have a profound impact on the shape of anything built on top of it. The primary requirements any $\mathrm{CBDC}$ will have to meet when providing the desired functionality to the new system are security, resilience, performance and adaptability. Meeting these goals will determine the design decisions made for a CBDC.

\section{CBDC requirements}

Security is the most important requirement in a CBDC. Central bank money is at the foundation of the financial system and any system that is used to transact with it must be secure. CBDC is another form of central bank money and has to have the highest level of security. This is the major consideration when addressing CBDC design. The trade-off being made is attack surface and functionality, the question is what is the maximum useful functionality available in the system for the simplest possible design so as to minimise the attack surface of the system.

CBDC has to be resilient as well as secure. Any CBDC system has to be able to withstand failure in any part of the system and continue functioning. A lot of the debate around $\mathrm{CBDC}$ concerns whether it should have a distributed ledger or not. In practice, every CBDC system will have multiple copies of the ledger 
because having a single copy is too great a risk if that ledger failed. The only question is how this redundancy is implemented. Increasing the number of copies of the ledger running in parallel increases the resilience of the system but there is a trade-off with performance. The real questions are what the degree of decentralization is, who can read and maintain copies of the ledger, and who can write to the ledger. How these capabilities are divided in the system is a policy question for the central bank - for example, whether the CBDC ledger should be public or private.

Performance is another key requirement. Ultimately a CBDC has to be capable of supporting every payment in the financial system - retail and wholesale. That does not necessarily mean that retail and wholesale CBDC have to be the same system, it is possible that two separate systems running in parallel could serve these two purposes, it is however unknown at this stage whether the distinction between retail and wholesale will persist into the future. The key issue when considering performance is what proportion of transactions pass through the core CBDC ledger. Existing high throughput payment systems use databases to run the ledger. With a CBDC, there are two approaches to scaling - one is to put as much as possible through the core ledger and focus on making the database as high-performance as possible. The alternative approach is to develop a system in which the CBDC acts as the core upon which a second layer can be built to scale up the larger system. The two-layer approach has architectural implications, as the core system will need sufficient functionality to facilitate the second layer.

The demands on a CBDC will alter over time. Any CBDC needs to be capable of adapting as the demands on it change. The goal is to create a CBDC system that does not need to be replaced every 20-30 years, as current systems do, but one that can be altered incrementally over time in response to new requirements as they emerge. For example, the CBDC needs to be designed in such a way that it can be implemented in different programming languages so that as older languages fall out of use, they can be replaced.

This avoids a current problem in the financial system whereby many legacy systems still rely on COBOL, though there is little continuing support for the language. Another aspect of adaptability is supporting innovation. It is impossible to predict at this stage all the uses to which a CBDC could be put. The larger goal of introducing a CBDC is to improve the functioning of the financial system. This means supporting an environment in which beneficial innovation can flourish. 


\section{Vision of the new financial system}

A clear vision of what the future financial system should look like is also fundamental to CBDC design. The ultimate goal is a financial system that has lower risk and greater competition.

This vision of the future financial system supported by a CBDC matters because it will affect how the CBDC is designed. If the existing financial system is taken as the template for the new financial system, then all the existing complexity of the system would have to be replicated. Since the crisis, policymakers have repeatedly expressed a desire for a simpler financial system with greater transparency and less risk. ${ }^{8}$ In this respect, the design of the financial system is similar to the design of a software system - greater complexity means more risk. Any CBDC design should support this larger policy goal of creating a simpler and less risky financial system.

Making the financial system more competitive is another important goal. One of the persistent problems in the financial system is the lack of competition and the rent extraction which results. ${ }^{9}$ Creating a CBDC system with a structure that reduces switching costs is important to making the overall financial system more competitive. In the next section we will look at some specific examples of this arising from how the CBDC is designed.

Another important issue to address is the balance of responsibilities between the central bank and the private sector. While the overall strategic goal is to simplify the financial system, the new system will still have to be capable of supporting useful innovation. This means it will change over time and that from the start the CBDC will have to be set up to facilitate this as not all the possible future use cases can be foreseen from the start. While the new financial system should be simpler than the existing system,, complexity cannot be completely eliminated. Private sector innovation will mean a set of functions being built on top of the CBDC which are more complex than the core system. This leads to the final issue of how to synthesise all we currently know about existing digital

8 See for example Basel Committee on Banking Supervision, The Regulatory Framework: Balancing Risk Sensitivity, Simplicity and Comparability, Discussion Paper, July 2013, https://www.bis.org/publ/bcbs258.htm.

9 For example antitrust cases against Visa brought by the US Department of Justice (US Department of Justice website: U.S. v. VISA U.S.A., et al., https://www.justice.gov/ atr/case/us-v-visa-usa-et-al); and against Mastercard by the European Commission (European Commission, Antitrust: Commission Accepts Commitments by Mastercard and Visa to Cut Inter-Regional Interchange Fees, 29 April 2019, https://ec.europa.eu/ commission/presscorner/detail/en/IP_19_2311. 
currencies, $\mathrm{CBDC}$ requirements and the vision of the future financial system into a viable $\mathrm{CBDC}$ design that takes all these considerations in to account.

\section{Implications for CBDC design}

Put together, the CBDC requirements and the vision of the future financial system point towards a CBDC with a simple design. The central bank should operate a small and resilient CBDC core that can facilitate other parts of the financial system, which can offer user-facing services and build greater complexity on top where needed. The core CBDC system can then rely on a second layer to scale the system rather than attempting to run everything through the core ledger. This approach is in keeping with the existing role of a central bank in the financial system, in which the core infrastructure is kept simple and fast, with the rest of the system built on top.

As CBDC is the third generation of digital currencies, it can learn the lessons of the first two generations. The most important lesson to learn is that relatively little programmability is required to implement useful functions such as a second layer, PvP and DvP. All a CBDC needs in the core system at this stage is signature locks, hashlocks and timelocks, which have been described in detail above. We learnt that most of the first generation functions were never actually used in practice and that all the useful features could be implemented with these three functions.

The added programmability in the second generation of digital currencies increased both complexity and the attack surface while adding features that will be unnecessary for a CBDC, where security is the highest priority. The overall lesson for CBDC from the first two generations of digital currencies is; less, not more.

\subsection{The new financial system}

In this section, we will take up the three examples addressed in the first part of the chapter - payments, PvP and DvP - to see how the new financial system could function with a CBDC and the effects this could have on its structure.

\section{Payments}

Any CBDC has to be designed to support the bulk of payments in the economy. This implies the system as a whole will have to process a very large volume of transactions. One design option is to route all CBDC payments through the 
main ledger operated by the central bank itself (the first layer). In such a setup, there would still be a role for the private sector in provide user-facing services such as wallets, point of sale and online payments processing, but every transaction, no matter how small, would hit the CBDC ledger. The core CBDC database could be optimised, but it would still be very difficult to scale to a point in which the tiniest payments were being processed directly by the central bank.

The alternative setup would be to structure the system to resemble the way Bitcoin supports payment channels, most notably the lightning network. ${ }^{10}$ In this design, the CBDC would process the larger transactions required to open and close payment channels. The central bank would focus on operating the core CBDC ledger and accepting that scaling the system falls to supporting an active second-layer network of payment channels, rather than pushing all the transaction processing into the core CBDC database. The advantage of this approach is that scaling the system to accommodate even micropayments across the whole economy becomes a much more viable proposition and does not put as much strain on the central bank system.

In addition to the scaling advantages of using a two-layer network, there are also competition benefits if the system is set up correctly. A two-layer network functions much like the Internet itself. When you visit a website, the data request between your computer (the client) and the website (the server) is routed through a number of different intermediating machines (routers), as is the data the server returns to the client to display the website. As with data on the Internet, a twolayer payment is routed through a number of different nodes before reaching its destination. Each node in the network will charge a small fee for routing the payment, making node provision a viable business. Figure 3.8 shows how two-layer routing works for CBDCs. The customer's wallet software calculates the fastest and cheapest route to get the payment to the merchant and executes the multihop payment. The payment channels between the nodes are anchored to the first-layer CBDC ledger with transactions that use signature locks and timelocks to function.

The competition advantage comes in by making it easy for the customer to switch between different nodes from one payment to the next. If any node in the system starts to overcharge relative to its peers, it will receive little traffic as the customer's wallet software routes around it to a cheaper option. Figure 3.9

10 Joseph Poon and Thaddeus Dryja, The Bitcoin Lightning Network: Scalable Off-Chain Instant Payments, 14 January 2016, https://lightning.network/docs. 


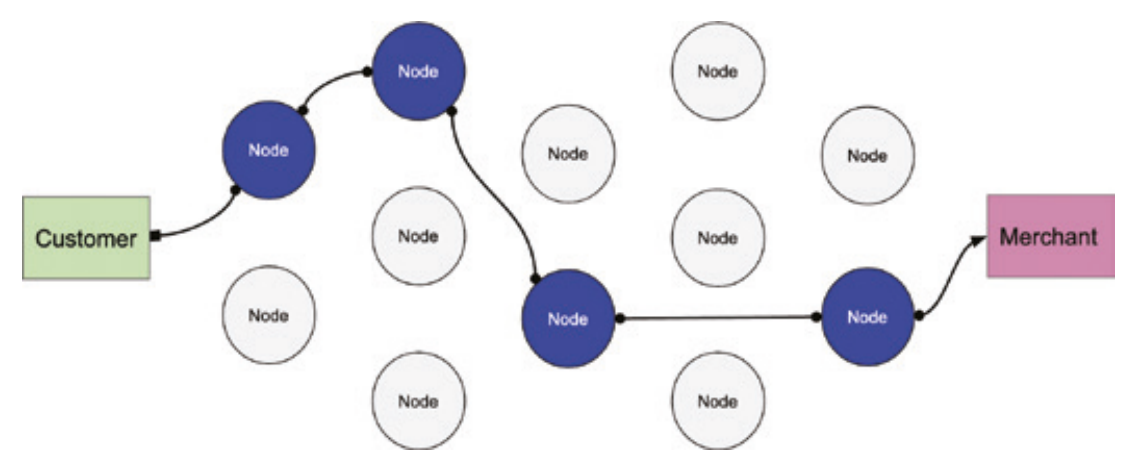

Figure 3.8: Payment routing.

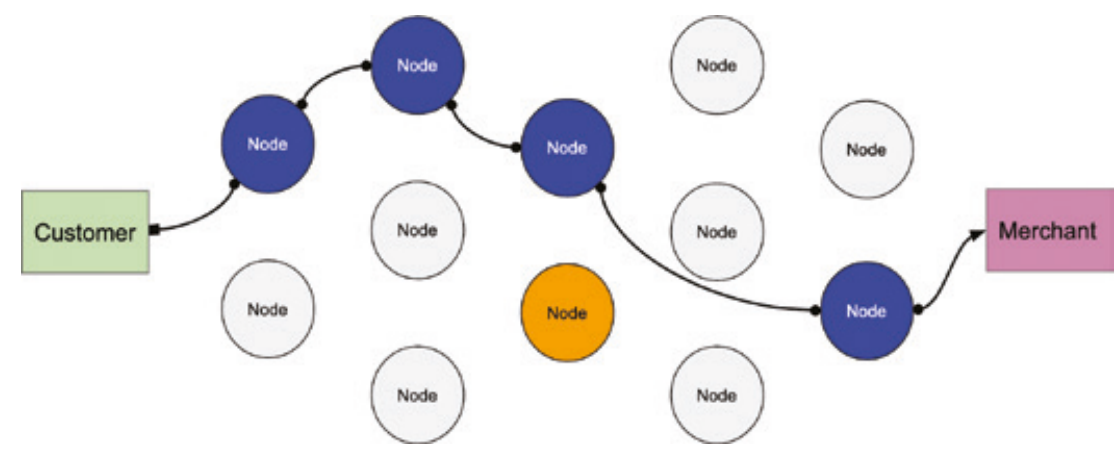

Figure 3.9: Switching in payment routing.

shows the payment being routed using a different path between customer and merchant, as the orange node in the original path raises its routing fee too high.

This system structure for second-layer payments in CBDC makes switching very low-cost and, as a result, facilitates competition. This is in contrast to existing payment networks in which a single provider routes the money from customer to merchant and the very high switching costs mean that fees can rise with little check from competition.

While the technology facilitates this increased competition it would also need a concerted policy focus to ensure that all the nodes were not consolidated into a single provider. There will be considerable incentive to do this, as once all the nodes between customers and merchants are controlled by a single entity, the rent-seeking that we see in the current system would rapidly return, regardless 
of the underlying technological architecture. This demonstrates that new technology alone will not solve the problems we have in the financial system if it is not combined with effective policy. New technology creates the opportunity to build a better system - it does not guarantee it.

\section{$P v P$ in a CBDC environment}

Implementing $\mathrm{PvP}$ using a $\mathrm{CBDC}$ requires a combination of signature locks, hashlocks and timelocks in the core ledgers. These are simple elements of programmability and can be implemented in a CBDC without creating a significant attack surface as the functionality in the core system is deliberately limited.

Figure 3.10 shows a simplified model of how Hashed Timelock Contracts (HTLCs $)^{11}$ can be used to implement PvP settlement with two different CBDCs. In this model it is assumed that both CBDCs have implemented the same basic functionality of signature locks, timelocks and hashlocks, such that the same HTLC Secret Z can be used in both transactions. HTLC Secret Z is the key that unlocks both transactions and, when combined with timelocks, ensures that both users can have confidence that both legs of the transaction will settle automatically. The HTLCs allow both CBDC systems to synchronise the two matching transactions without any direct link between the two underlying CBDCs.

This is a simplified model as in reality, the transaction would not settle directly between the two users because currency transactions would still need marketmakers. This highlights an important point about CBDC: its purpose is not to eliminate intermediation but to change its nature such that risk is reduced and competition is increased. As with the payment routing described above, the goal of CBDC, or a system of multiple CBDCs in this case, is to support a new financial system to develop around it.

While the underlying CBDC ledgers can operate completely independent of each other in this setup, the issuing central banks would have to agree on some common standards on how signature locks, hashlocks and timelocks are implemented in their systems such that this cross-currency settlement could work.

Allowing the CBDC systems to interoperate would bring a great deal of benefit to the system as a whole, and an important part of CBDC prototyping at different central banks should be experimenting with how these standards could

11 For an explanation of how HTLCs work at a technical level see part 4 of Joseph Poon and Thaddeus Dryja, The Bitcoin Lightning Network: Scalable Off-Chain Instant Payments, cit. 


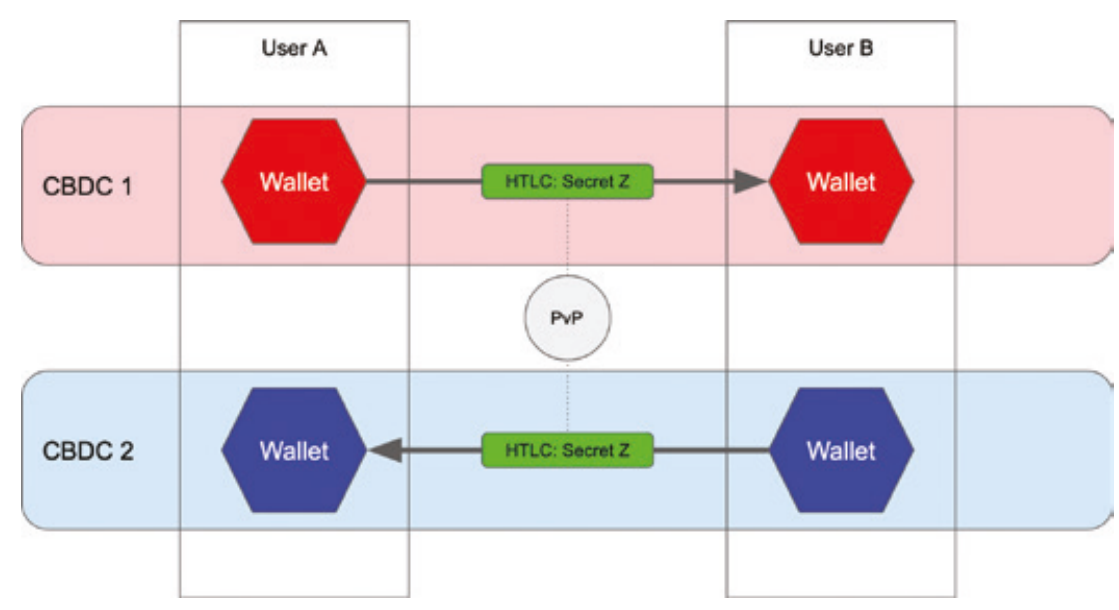

Figure 3.10: PvP using HTLCs.

be developed. There has already been international cooperation between central banks undertaking CBDC research, for example between the ECB and Bank of Japan, ${ }^{12}$ as well as the Monetary Authority of Singapore and Bank of Canada. ${ }^{13}$ Future CBDC research should build on these cross-border experiments to determine how different underlying CBDC systems can interact with each other successfully while retaining their independence from each other.

\section{DvP in a CBDC environment}

From a practical perspective, as with the existing financial system, DvP uses the same underlying method as PvP (hashed timelock contracts). To a machine a ledger of securities and a CBDC ledger are fundamentally the same - just a structured list of records. If the securities ledger is set up to facilitate hashlocks, timelocks and signature locks, then it will be relatively easy to implement DvP. It

12 Bank of Japan, Project Stella: the ECB and the Bank of Japan Release Joint Report on Distributed Ledger Technology (Phase 4), 12 February 2020, https://www.boj.or.jp/en/ announcements/release_2020/rel200212a.htm.

13 Monetary Authority of Singapore, Central Banks of Canada and Singapore Conduct Successful Experiment for Cross-Border Payments Using Distributed Ledger Technology, 2 May 2019, https://www.mas.gov.sg/news/media-releases/2019/central-banks-ofcanada-and-singapore-conduct-successful-experiment-for-cross-border-payments. 
may even be possible for the securities ledger to make use of an adapted version of an open source CBDC codebase to run its ledger.

Although a modified version of the CBDC ledger could be used to issue securities, the difference would be the structure of the issuer itself. With a CBDC this is straightforward, the issuer is the central bank. Securities have different types of issuer, the majority of them private entities. It is possible that companies may opt to manage the ledgers of their shares and bonds in issue themselves rather than delegating the task to a CSD. The difference is that unlike a central bank, which has the authority to issue a CBDC itself, private companies need authorization from securities regulators to offer their financial assets for sale publicly.

Securities regulators could allow companies to run their own ledgers or license third parties to do it on the companies' behalf as it may be that some companies do not wish to run their own securities ledgers and delegate this to another entity. The overall effect is to create a financial system with greater decentralization and more resembles a peer-to-peer network than the current hub and spoke model with large entities dominating the financial system and the negative systemic effects that brings.

Moving towards this model of a decentralised financial system requires a number of changes, one of which is allowing securities settlement to function in a more decentralised way. Once companies have the option of hosting their own ledgers of shares and bonds, it puts competitive pressure on incumbent intermediaries in the financial system to lower their prices.

While it is true that trading and settlement of vanilla securities is relatively low cost, from a technological perspective it makes sense to automate the simpler aspects of the financial system such as DvP before moving on to the more complex parts. Building this foundation will also yield useful insights into how the rest of the system should be designed.

\section{Shape of the new financial system}

Money and relatively simple financial instruments such as securities form the foundation of the financial system. We can see how creating CBDCs and trading securities using similar ledgers can alter the structure of the system such that it resembles a peer-to-peer network more closely. In such a system, multiple entities would compete to provide services in which switching costs are much lower. This contrasts with the current financial system, which, while still a network, has more of a hub-and-spoke model in which powerful intermediaries act as gatekeepers for different parts of the financial system. 
The steps described in this chapter are aimed at the foundational layers of the financial system. CBDCs offers central banks and other policymakers a unique opportunity to re-engineer the financial system in a way that regulations alone do not. This does not mean that regulations will not have a part to play. In addition to competition enforcement to ensure that rent extraction does not creep back into the system through consolidation of competing services, financial regulations can also play a beneficial role.

More decentralised technological architecture alone will not be sufficient to maintain a flatter structure to the financial system. Regulation is still needed to prevent entities emerging in the new financial system that are too big to fail. A key element of financial services reform is to create a new financial system in which failure of individual firms cannot threaten the integrity of the wider system. Failure of individual firms is, in fact, desirable as free entry and exit are a critical aspect of maintaining a competitive market structure.

Another method through which CBDC can improve the financial system is data standards. By creating the foundation of the new financial system, central banks can have considerable influence on how the rest of the system looks through the operation of both standards and open source software. In the DvP section above, we described how companies could adapt CBDC software to different use cases, such as securities. The software defines how the data is structured and passed through the system, so by setting the standards for CBDC as the foundation of the system, the central bank influences how the rest of the system will work from a technical perspective.

Making the data the financial system runs on more standardised and machinetractable creates the opportunity for better tools and greater automation. A longstanding goal for macroprudential policymakers has been a 'weather map' of the financial system that allows them to see major risk in the system as a whole, rather than trying to piece it together from data on individual firms. ${ }^{14}$ The key to making this approach work is high-quality standardised data that can be processed into a picture of the whole financial system.

Improved data quality also allows the financial system to make more use of machine learning and artificial intelligence to operate the financial system. We can see the start of this already in the existing financial system, with algorithmic

14 Andrew Haldane, Tails of the Unexpected, paper presented at the conference 'The Credit Crisis Five Years On: Unpacking the Crisis', held at the University of Edinburgh Business School, 8-9 June 2012, https://www.bankofengland.co.uk/speech/2012/ tails-of-the-unexpected. 
trading and greater automation in credit risk assessment. While human influence is still needed in these systems to ensure that bias from the data is not simply encoded into an algorithm, our aim for the new financial system is performing its necessary functions in the most efficient way possible. Ultimately the financial system is a set of digital records that need to be reliably updated and maintained. The more we can simplify and automate this record-keeping the more efficient it will be. CBDC is not a complete solution but it is the key to unlocking the benefits of a new financial system that extracts less and serves better.

\section{References}

Raphael Auer and Rainer Boehme, 'The Technology of Retail Central Bank Digital Currency', in BIS Quarterly Review, March 2020, p. 85-100, https:// www.bis.org/publ/qtrpdf/r_qt2003j.htm

Bank of England, Central Bank Digital Currency. Opportunities, Challenges and Design, Discussion Paper, March 2020, https://www.bankofengland.co.uk/ paper/2020/central-bank-digital-currency-opportunities-challenges-anddesign-discussion-paper

Bank of Japan, Project Stella: the ECB and the Bank of Japan Release Joint Report on Distributed Ledger Technology (Phase 4), 12 February 2020, https://www. boj.or.jp/en/announcements/release_2020/rel200212a.htm

Basel Committee on Banking Supervision, The Regulatory Framework: Balancing Risk Sensitivity, Simplicity and Comparability, Discussion Paper, July 2013, https://www.bis.org/publ/bcbs258.htm

Committee on Payment and Settlement Systems, 'Principles for Financial Market Infrastructures', in CPMI Papers, No. 101 (April 2012), https://www. bis.org/cpmi/publ/d101.htm

European Commission, Antitrust: Commission Accepts Commitments by Mastercard and Visa to Cut Inter-Regional Interchange Fees, 29 April 2019, https://ec.europa.eu/commission/presscorner/detail/en/IP_19_2311

Andrew Haldane, Tails of the Unexpected, paper presented at the conference 'The Credit Crisis Five Years On: Unpacking the Crisis', held at the University of Edinburgh Business School, 8-9 June 2012, https://www. bankofengland.co.uk/speech/2012/tails-of-the-unexpected

Monetary Authority of Singapore, Central Banks of Canada and Singapore Conduct Successful Experiment for Cross-Border Payments Using Distributed Ledger Technology, 2 May 2019, https://www.mas.gov.sg/news/mediareleases/2019/central-banks-of-canada-and-singapore-conduct-successfulexperiment-for-cross-border-payments 
Satoshi Nakamoto, Bitcoin: A Peer-to-Peer Electronic Cash System, March 2009, https://bitcoin.org/en/bitcoin-paper

Katharina Pistor, The Code of Capital. How the Law Creates Wealth and Inequality, Princeton/Oxford, Princeton University Press, 2019 Joseph Poon and Thaddeus Dryja, The Bitcoin Lightning Network: Scalable OffChain Instant Payments, 14 January 2016, https://lightning.network/docs 



\section{Steven L. Schwarcz \\ Chapter 4: Central Bank Digital Currencies and Law}

This chapter examines the legal issues surrounding a 'retail' central bank digital currency (CBDC) - one that is used by consumers on a day-to-day basis as an alternative to cash. ${ }^{1}$ Most discussions about CBDC focus on its purported benefits and initial design questions. Little is written about how existing laws and regulations will extend to CBDCs or what new regulations will have to be implemented. ${ }^{2}$ This chapter engages in that analysis.

The analysis assumes that future retail CBDCs will be account-based, meaning the currency will be represented by book entries in accounts that are held and managed by banks. The central bank will prescribe interest rates on these accounts, and rules and regulations for their governance and use. Much of the existing infrastructure of both central and commercial banks ${ }^{3}-$ as well as the widespread application of that infrastructure to so-called 'wholesale' electronic funds transfers between businesses and financial institutions ${ }^{4}-$ is already account-based, ${ }^{5}$ and much of the recent literature on CBDC assumes the account-based system. ${ }^{6}$

1 Steven L. Schwarcz is the Stanley A. Star Distinguished Professor of Law \& Business at Duke University School of Law and Senior Fellow at the Centre for International Governance Innovation (CIGI). The author would thank Benjamin Geva and Lev Menand for excellent comments and Eric Horsley and Carson Calloway for invaluable research assistance.

2 Patrycja Beniak, 'Central Bank Digital Currency and Monetary Policy: A Literature Review', in MPRA Papers, No. 96663, 26 October 2019, p. 2, https://mpra.ub.unimuenchen.de/96663.

3 For convenience, this chapter refers to commercial banks broadly, as including all non-governmental banks.

4 See Article 4A of the Uniform Commercial Code (UCC), Prefatory Note.

5 Financial institutions in the United States, for example, hold accounts at the Federal Reserve and use Fedwire to transfer money between these accounts. See Fedwire Funds Service website: Product Sheet, https://www.frbservices.org/assets/financial-services/ wires/funds.pdf.

6 See, e.g., Morgan Ricks, John Crawford and Lev Menand, 'FedAccounts: Digital Dollars', in George Washington Law Review, forthcoming (15 April 2020), https://ssrn. com/abstract=3192162 (focusing on a Federal Reserve Bank account-based system). 
A retail account-based CBDC would likely use technologies largely already in place at banks and merely extend their access to a wider user base. That is because any account-based digital currency, whether wholesale or retail, ${ }^{7}$ would operate through electronic funds transfers. ${ }^{8}$ To that extent, digital currency transfers are synonymous with electronic funds transfers.

This calls into question why retail CBDC should be regulated any differently than wholesale electronic funds transfers. As this chapter will show, it should not generally be regulated differently - with relatively few exceptions, such as consumer protection.

Two primary sources of regulation currently govern wholesale electronic funds transfers. Those funds transfers are governed in the European Union by the European Directive on payment services in EU internal markets (the 'EU Directive'), and in the United States by Article 4A of the Uniform Commercial Code (UCC). As this chapter will show, Article $4 \mathrm{~A}$ is the more relevant regulatory

The digital currency being developed by the People's Bank of China appears to be an account-based system, though details remain confidential. Cf. Anton N. Didenko et al., 'After Libra, Digital Yuan and COVID-19: Central Bank Digital Currencies and the New World of Money and Payment Systems', in UNSW Law Research Series, No. 65/2020 (30 SEPTEMBER 2020), https://ssrn.com/abstract=3622311 (discussing how China's digital currency will be transferred). Although some claim that consumers lacking a bank account will be able to use China's digital currency, the details are sparse. See Karen Yeung, 'What Is China's Cryptocurrency Alternative Sovereign Digital Currency and Why Is It Not Like Bitcoin?', in South China Morning Post, 13 May 2020, https://www. scmp.com/economy/china-economy/article/3083952/what-chinas-cryptocurrencysovereign-digital-currency-and-why (claiming digital wallets can be used without linking to a bank account). But cf. Benjamin Geva, 'Virtual Currencies and the State', in Just Money, 22 April 2020, https://wp.me/paGDrD-10W (arguing that efficiency gains from disintermediation favor token-based CBDCs, though with concomitant risks). See also the chapter by Robleh Ali in this volume.

7 All funds transfers can be classified as either wholesale or retail. Bank for International Settlements (BIS), Annual Economic Report 2020, 30 June 2020, p. 68, https://www.bis. org/publ/arpdf/ar2020e.htm.

8 Cf. Charles M. Kahn and William Roberds, 'The Design of Wholesale Payments Networks: The Importance of Incentives', in Federal Reserve Bank of Atlanta Economic Review, Vol. 84, No. 3 (1999), p. 30-39, https://www.frbatlanta.org/research/ publications/economic-review/1999/q3/vol84no3_design-of-wholesale-paymentsnetwork.aspx; Committee on Payment and Settlement Systems, 'The Role of Central Bank Money in Payment Systems', in CPMI Papers, No. 55 (12 August 2003), https:// www.bis.org/cpmi/publ/d55.htm (observing that wholesale funds transfers between banks are already settled digitally). 
precedent because it covers in much greater depth the rights, obligations, and liabilities of banks and other intermediaries involved with the transfers. ${ }^{9}$ Article 4A's regulatory framework for wholesale wire transfers also has been widely influential both within the United States and internationally. ${ }^{10}$

In the United States, Article $4 \mathrm{~A}$ has been enacted in all 50 states $^{11}$ and governs both of the principal electronic payment systems - the Federal Reserve wire transfer network (Fedwire), and the New York Clearing House Interbank Payments System (CHIPS). ${ }^{12}$ Internationally, Article 4A and the United Nations Commission on International Trade Law's (UNCITRAL) Model Law on International Credit Transfers use the same framework for classifying entities and transactions in wire transfers (for example, both focus on credit transfers and speak in terms of originators/beneficiaries and payment orders to banks). ${ }^{13}$ Also, both Article 4A and UNCITRAL's Model Law influenced the EU Directive. ${ }^{14}$

9 The European Directive covers both credit and debit transfers, whereas Article 4A covers only credit transfers. See Benjamin Geva, 'Payment Transactions under the E.U. Second Payment Services Directive-An Outsider's View', in Texas International Law Journal, Vol. 54, No. 2 (2019), p. 215, https://digitalcommons.osgoode.yorku.ca/ scholarly_works/2718. However, the distinction between credit and debit transfers is not an organizational principle in the Directive. Also, notwithstanding the Directive's slightly broader coverage, it lacks depth compared to Article 4A.

10 Mark Sneddon, 'The Effect of Uniform Commercial Code Article 4A on the Law of International Credit Transfers', in Loyola of Los Angeles Law Review, Vol. 29, No. 3 (April 1996), p. 1111-1112, https://digitalcommons.lmu.edu/llr/vol29/iss3/11; Barkley Clark and Barbara Clark, The Law of Bank Deposits, Collections and Credit Cards, 3rd ed., Boston, Warren, Gorham \& Lamont, 1990, para. 17.02, (2)(d).

11 Uniform Law Commission, UCC Article 4A, Funds Transfers, https://www.uniformlaws. org/committees/community-home?CommunityKey=2985cf6d-9c22-4abe-abf11f36f8a27201.

12 Code of Federal Regulations (CFR), title 12, para. 210.25; Clearing House Interbank Payments System (CHIPS), Public Disclosure of Legal, Governance, Risk Management, and Operating Framework, June 2020, p. 12, https://www.theclearinghouse.org/-/ $\mathrm{media} / \mathrm{new} / \mathrm{tch} /$ documents/payment-systems/chips_public_disclosure_june_2020. pdf.

13 See generally Carl Felsenfeld, 'The Compatibility of the UNICTRAL Model Law on International Credit Transfers with Article 4A of the UCC', in Fordham Law Review, Vol. 60, No. 6 (1992), p. 53-75, https://ir.lawnet.fordham.edu/flr/vol60/iss6/4.

14 Cf. Mark Sneddon, 'The Effect of Uniform Commercial Code Article 4A on the Law of International Credit Transfers', cit., p. 1109 (remarking on the influence of UCC Article 4A on the European Commission's proposed Directive on cross-border credit transfers). 
Additionally, both Fedwire and CHIPS have choice-of-law provisions which specify that Article $4 \mathrm{~A}$ will apply to all funds transfers processed in whole or in part by their systems. ${ }^{15}$

Article 4A's framework also includes a consistent vocabulary for describing funds transfers and a precise allocation of rights, obligations, and liabilities among participating financial institutions and their customers, who initiate and receive wire-transfer payments. ${ }^{16}$ Transferring funds from one customer's electronic bank account to that of another customer should be the same, in principle, whether the transfer is retail or wholesale. ${ }^{17} \mathrm{~A}$ retail customer would initiate a funds transfer by sending a payment order to his bank; that bank would then (provided its customer's account has sufficient funds) send a payment order through, for example, Fedwire to the beneficiary's bank; and the beneficiary's bank would (again, subject to receiving funds) credit the beneficiary's account. ${ }^{18}$

Thus, while Article $4 \mathrm{~A}$ is designed for wholesale wire transfers, it should - at least with certain consumer-protection provisions, discussed below - provide a suitable regulatory framework for retail CBDC transactions. To understand why, consider the key legal issues of a retail CBDC: (1) risk of loss; (2) counterfeiting protection; (3) privacy and data keeping; (4) anti-money laundering; and (5) consumer protection.

1) Risk of loss. Risk of loss includes at least three risks: mistakenly transferring funds to the wrong person; fraud risk, including fraudulently transferring funds to a wrong person; and credit risk, including the risk of the 'receiving bank' paying out before being paid. Article $4 \mathrm{~A}$ covers these risks as follows. ${ }^{19}$

15 CFR, title 12, para. 210.25 (b)(2); CHIPS, Public Disclosure of Legal, Governance, Risk Management, and Operating Framework, cit., p. 12.

16 See generally UCC para. 4A. Available in the Legal Information Institute (LII) website: https://www.law.cornell.edu/ucc/4A.

17 Cf. Morgan Ricks, John Crawford and Lev Menand, 'FedAccounts: Digital Dollars', cit., p. 15 (arguing that retail CBDC transactions could use the same wire transfer system currently used by the central bank).

18 Cf. Federal Reserve Banks: FedNow Service Product Sheet, https://www.frbservices.org/ assets/financial-services/fednow/fednow-product-sheet.pdf (describing the payment flow for a credit transfer using the proposed FedNow interbank real-time settlement service, targeted to be available in 2023 or 2024, to enable financial institutions to deliver faster payment services to their customers).

19 The EU Directive provides banks with less discretion in the choice to accept a payment order. This could reduce the bank's incentive to do as much due diligence as it otherwise would. 
(a) Mistaken transfer. Under UCC para. 4A-207, a payment order with a nonexistent or unidentifiable person or account does not create a right in a person to receive the payment. Where the name and account number are known to the beneficiary's bank, however, that bank may pay the person referred to by the account number. ${ }^{20}$

One possible small adjustment appropriate to adapt Article 4A to regulate retail CBDC transactions is in para. 4A-207. Under subsection (a) of that section, if the name or bank account number of a payment order received by the beneficiary's bank refers to a nonexistent or unidentifiable person or account, no person has the right as a beneficiary to receive the payment - except as provided in subsection (b). Subsection (b) provides that if the name and bank account number associated with a particular payment order refer - unbeknownst to the beneficiary's bank - to different individuals (i.e., the name to one person and the bank account number to another), the beneficiary's bank may pay the person referred to by the account number. ${ }^{21}$ This level of flexibility may make sense for wholesale wire transfers, because in larger transactions, especially business transactions, the parties may devote more care to provide the correct information so errors should be relatively rare. Retail wire transfers may be more error prone..$^{22}$ For that reason, at least from the customers' standpoint, the stricter rule of subsection (a), that both the name and bank account number match, make sense. Still, that rule should be balanced by banking realities. At least currently, a 'very large percentage of payment orders issued to the beneficiary's bank' are 'processed by automated means using machines capable of' identifying 'the number of a bank account,' and 'without human reading of the payment order itself.'23

(b) Fraud. UCC paras. 4A-202 to 4A-204 address authorization and acceptance of payment orders issued in the name of a customer. UCC para. 4A-202(a) points to the law of agency to resolve a dispute where the person identified as sender refuses to pay on the grounds that it did not authorize the payment order. For example, if the payment order is

20 Cf. infra notes 21-22 and accompanying text (providing a more detailed explanation).

21 UCC para. 4A-207(b).

22 A retail customer, for example, may be more likely to make a mistake when wiring 20 US dollars to a babysitter than a wholesale customer would be when wiring 25,000 US dollars to pay for a shipment of inventory.

23 Official Comment to UCC para. 4A-207, point 2. Available in the D.C. Law Library website: https://code.dccouncil.us/dc/council/code/sections/28:4A-207.html. 
sent by an officer of a corporation, the question would be whether that officer is an agent of the corporation with the power to authorize payment orders on the corporation's behalf. More commonly, a bank and its customer agree to security procedures that, if followed, result in an authorized payment order. ${ }^{24}$

(c) Credit risk. Under UCC para. 4A-405(d), a 'funds-transfer system rule may provide that payments made to beneficiaries of funds transfers made through the system are provisional until receipt of payment by the beneficiary's bank of the payment order it accepted.' UCC para. 405(d) continues by providing conditions that, if met, would entitle the beneficiary's bank to a refund.

2) Counterfeiting protection. Counterfeiting is defined as 'the replication or manufacture of a financial instrument [...] with the intent to defraud an individual, entity, or government. ${ }^{25}$ Traditionally, the counterfeiting risk for money has been concerned with illicit production of physical representations of the money, such as the unauthorized reproduction of US dollar bills. The protections involve increasing the complexity and markings of bills. ${ }^{26}$ These concerns have no obvious parallel for an account-based CBDC.

There are two possible ways to counterfeit an account-based CBDC, although both also could be classified as fraud: by double spending, and by making transfers involving an unverified account. ${ }^{27}$ Double spending can occur when a payor uses the same money in an account to make two purchases before the transactions clear in the payment system..$^{28}$ Transfers involving an unverified account can occur when a payee causes the bank to credit money from a phantom account, which only appears to exist, to the payee's account and

24 UCC para. 4A-202(b).

25 Ralph E. McKinney et al., 'The Evolution of Financial Instruments and the Legal Protection Against Counterfeiting: A Look at Coin, Paper, and Virtual Currencies', in Journal of Law, Technology \& Policy, No. 2 (2015), p. 299, http://illinoisjltp.com/journal/ wp-content/uploads/2015/12/McKinney.pdf.

26 Ibid., p. 302-303.

27 See Committee on Payments and Market Infrastructures, 'Central Bank Digital Currencies', in CPMI Papers, No. 174 (12 March 2018), p. 4, https://www.bis.org/cpmi/ $\mathrm{publ} / \mathrm{d} 174$.htm (observing that the form of verification needed differs between tokenbased and account-based money).

28 Cf. ibid., p. 4, note 5 (observing the double spending problem for digital tokens). This chapter's reference to double spending includes, of course, any multiple spending of the same money in an account. 
then quickly withdraws the money. ${ }^{29}$ To the extent an account-based CBDC makes use of existing banking technology and systems (which is likely), ${ }^{30}$ these counterfeiting risks should be comparable to counterfeiting risks in current wholesale electronic banking. ${ }^{31}$

Article $4 \mathrm{~A}$ covers these counterfeiting risks. It does not compel a bank to process transactions under conditions that might result in double spending, ${ }^{32}$ such as when there are insufficient funds in an account..$^{33}$ Furthermore, existing account agreements authorize debits contingent on there being available balances. ${ }^{34}$ The current banking system is thus already well guarded against the risk of double spending. A retail CBDC modelled off the current electronic banking system should inherit the same (low) risk of double spending. Likewise, Article 4A does not compel a bank to process transactions involving an unverified account. A bank has no obligation to accept a payment order. ${ }^{35}$ Because acceptance obliges it to pay the receiving bank, ${ }^{36}$ a sending bank has

29 See, e.g., Lily Hay Newman, 'How Hackers Pulled Off a \$20 Million Mexican Bank Heist', in Wired, 15 March 2019, https://www.wired.com/story/mexico-bank-hack (discussing a transfer initiated by hackers from a phantom account to a real account within the bank).

30 Morgan Ricks, John Crawford and Lev Menand, 'FedAccounts: Digital Dollars', cit., p. 3.

31 The security threat caused by a possible centralization of accounts in the central bank would still need to be considered.

32 Neither UCC Article 4A nor the Electronic Fund Transfer Act (EFTA) compels a bank to process a transaction when there are insufficient funds in an account. Under UCC para. 4A-212, absent an explicit agreement, a bank has no duty to accept a received payment order. The EFTA, as codified in part in the United States Code (USC), title 15, para. 1693h (https://www.law.cornell.edu/uscode/text/15/1693h), makes insufficient funds in a customer's account an explicit exception to a bank's liability for damages caused by a failure to make an electronic funds transfer.

33 Under UCC para. 4A-212, absent an explicit agreement, a bank has no duty to accept a received payment order. The EFTA, as codified in part in USC, title 15, para. $1693 \mathrm{~h}$, makes insufficient funds in a customer's account an explicit exception to a bank's liability for damages caused by a failure to make an electronic funds transfer.

34 E.g., Wells Fargo Bank, Deposit Account Agreement (Effective July 24, 2019), p. 44, https://www.wellsfargo.com/fetch-pdf?formNumber=CCB2018C\&subProductCode $=$ ANY. Given both the legal framework (see UCC Article 4A, Prefatory Note) and the account agreements banks have crafted, double spending is a small risk in an accountbased system where a third party - the bank-oversees a transaction.

35 Morgan Ricks, John Crawford and Lev Menand, 'FedAccounts: Digital Dollars', cit., p. 3.

36 UCC para. 4A-402(c). 
an incentive to ensure that funds are available for reimbursement before it accepts a payment order.

3) Privacy and data keeping. Central bank digital currencies may help to centralize data about the money supply. To the extent CBDC impacts privacy for example, by making funds transfers easier to trace - how should privacy and access to capital be balanced? Governments generally protect their citizens' privacy better than private entities, such as a non-government sponsor of a digital currency. ${ }^{37}$

It also may be interesting to consider if a kind of central-commercial bank 'federalism' is more effective when it comes to security measures to protect privacy. If the account-based CBDC is a totally centralized system, then any security vulnerability is systemic, everyone will be affected. However, if the account-based CBDC makes use of infrastructure and security measures at commercial banks, then a vulnerability at one bank would not necessarily be present at other commercial banks (because of the variability of security measures in place).

4) Anti-money-launderinglaws. AMLlaws generally follow the recommendations of the Financial Action Task Force (FATF), an inter-governmental body. ${ }^{38}$ The FATF seeks 'to set standards and promote effective implementation of legal, regulatory and operational measures for combating money laundering, terrorist financing and other related threats to the integrity of the international

37 Cf. Federal Trade Commission, FTC Imposes \$5 Billion Penalty and Sweeping New Privacy Restrictions on Facebook, 24 July 2019, https://www.ftc.gov/node/1536925 (reporting that Facebook agreed to pay a penalty of 5 billion US dollars to settle charges that it 'violated a 2012 FTC order by deceiving users about their ability to control the privacy of their personal information'); Natasha Lomas, 'Libra, Facebook's Global Digital Currency Plan, Is Fuzzy on Privacy, Watchdogs Warn', in TechCrunch, 5August 2019, https://techcrunch.com/?p=1864705 (noting the lack of detailed information on Libra's privacy protections and describing the concerns of a set of international privacy watchdogs); Spencer Bokat-Lindell, 'Can We Trust Facebook to Run a Bank?', in The New York Times, 24 October 2019, https://nyti.ms/32JdwNz (discussing privacy concerns over Libra).

38 The FATF was established by the 1989 G-7 Summit in Paris, with the mission of addressing the threat posed to the banking system and to financial institutions by money laundering. Its mission expanded in 2001 to counter the use of the financial system for terrorism financing. There currently are 39 members of the FATF, covering many of the largest financial hubs. FATF website: History of the FATF, https://www. fatf-gafi.org/about/historyofthefatf. 
financial system. ${ }^{39}$ To this end, it makes recommendations for an AML legal framework in member countries. ${ }^{40}$

If the introduction of a CBDC leaves the commercial banking sector as the retail depository institutions, no change should be needed, in principle, to AML laws because the CBDC would not impact the FATF recommendations. Changes to AML laws might be needed, though, if the CBDC scheme contemplates that retail CBDC account holders have accounts directly with the central bank; that would raise questions whether the central bank or commercial banks should be obligated to meet the recommendation's requirements.

In practice, however, a retail CBDC might require certain changes to AML laws. For example, FATF Recommendation 10 creates an obligation for financial institutions to conduct customer due diligence (also known as KnowYour-Customer (KYC) laws). If this recommendation requires every retail transaction to be scrutinized, it would impose high transaction costs due to the sheer volume of those transactions. ${ }^{41}$ To reduce these costs, AML laws could place a floor on the value of transfers that would trigger the need to conduct customer due diligence. ${ }^{42}$

5) Consumer protection. Although UCC Article 4A covers many domestic and international electronic funds transfers, it was designed for use by relatively sophisticated parties, such as businesses and financial institutions. ${ }^{43}$ In the United States, the Electronic Fund Transfer Act (EFTA) governs a range of existing retail electronic funds transfers, including ATM deposits and

39 FATF website: What Do We Do, https://www.fatf-gafi.org/about/whatwedo.

40 FATF, The FATF Recommendations. International Standards on Combating Money Laundering and the Financing of Terrorism \& Proliferation, June 2019, http://www. fatf-gafi.org/publications/fatfrecommendations.

41 FATF Recommendation 17 (ibid., p. 16) allows financial institutions to outsource their customer due diligence requirements to third parties; however, liability remains with the delegating party. For a retail CBDC this could mean central banks are outsourcing customer due diligence to commercial banks. In may be preferable, contra Recommendation 17, to have commercial banks responsible to the central bank for failed due diligence.

42 Cf. CFR, title 31, para. 1010.311 (setting US reporting practices requiring financial institutions only to report 'each deposit, withdrawal, exchange of currency or other payment or transfer, by, through, or to such financial institution which involves a transaction in currency of more than $\left.\$ 10,000^{\prime}\right)$.

43 See supra note 4 and accompanying text. 
withdrawals and most mobile payment apps (such as PayPal, Venmo, and Zelle). ${ }^{44}$

In contrast to Article 4A, the EFTA pays little attention to what electronic funds transfers consist of or how they are carried out; rather, the primary purpose of the EFTA is one of consumer protection: to give consumers certain rights when engaging in electronic funds transfers. ${ }^{45}$ For example, the EFTA limits consumer liability for unauthorized transactions, ${ }^{46}$ ensures that banks adequately inform consumers of their rights, ${ }^{47}$ protects consumers from being charged excessive fees ${ }^{48}$ and gives consumers a means of redressing erroneous transactions. ${ }^{49}$

To illustrate these different regulatory approaches, assume a customer of Bank A accidently discloses information that enables a third party to make an unauthorized transaction. Under Article 4A, the customer will be liable for the unauthorized transaction so long as Bank A, in good faith, follows a commercially reasonable, and mutually agreed upon, security procedure. ${ }^{50}$ Under the EFTA, the customer's liability for the unauthorized transaction is subject to a dollar limitation. ${ }^{51}$ Another important difference between Article 4A and the EFTA is the extent to which customers and their banks can vary the terms of their agreements. Article $4 \mathrm{~A}$ affords much more flexibility to contractually vary the rights and obligations of a party to an electronic funds transfer. So long as Article $4 \mathrm{~A}$ does not expressly provide otherwise, the terms of a funds transfer can be varied..$^{52}$ The EFTA does not permit consumer rights to be waived. ${ }^{53}$

44 CFR, title 12, para. 205.3. In part because of the Supremacy Clause of the US Constitution, the EFTA, which is federal law, supersedes inconsistent provisions of Article 4A, which is state law. Cf. UCC para. 4A-108 and Official Comment, point 1 (stating and explaining the EFTA's supremacy).

45 USC, title 15, para. 1693.

46 USC, title 15, para. 1693g.

47 USC, title 15, para. $1693 \mathrm{c}$.

48 USC, title 15, para. $16930-2$.

49 USC, title 15, para. $1693 \mathrm{f}$.

50 Francis J. Facciolo, 'Unauthorized Payment Transactions and Who Should Bear the Losses', in Chicago-Kent Law Review, Vol. 83, No. 2 (April 2008), p. 614, https://scholarship.kentlaw.iit.edu/cklawreview/vol83/iss2/6.

51 USC, title 15, para. 1693g(a) (limiting that liability to 50 US dollars if Bank A is properly notified of the unauthorized transaction, and otherwise 500 US dollars).

52 UCC para. 4A-501.

53 USC, title 15, para. 16931. 
These differences between Article 4A and the EFTA reflect their different purposes. Article 4A was written with wholesale funds transactions in mind and contemplates sophisticated users. CBDC regulation thus should draw from Article $4 \mathrm{~A}$ to the extent such regulation governs how electronic funds transfers should occur - through a series of payment orders between clearly defined parties - and how generally to allocate rights and obligations between those parties. In contrast, the EFTA was written to protect everyday retail customers, and this policy goal is reflected in provisions that limit consumer liabilities and protect their rights. CBDC regulation thus also should draw from the EFTA to the extent regulators regard retail users of $\mathrm{CBDC}$ to need overriding consumer protection.

This chapter has so far examined what law should apply to a retail CBDC. A related issue is which regulators should apply that law. Although that issue is largely beyond this chapter's scope, a few observations are in order. When international wholesale funds transfers are made, regulators may supervise the relevant aspects of the transfers at their national level. Consider, for example, a cross-border funds transfer sent through the CHIPS clearing system ${ }^{54}$ from a CHIPS participant bank in the United States to a CHIPS participant bank in Germany. ${ }^{55}$ Regulators in the United States would supervise the sending bank, and the Federal Reserve regulates the US activities of CHIPS.$^{56}$ Regulators in Germany, and Europe more broadly, presumably would supervise the receiving bank. ${ }^{57}$ As a result, there is no current need for an international regulator to supervise cross-border wholesale electronic funds transfers, nor would there appear to be a need for such a regulator to supervise cross-border retail electronic funds transfers. This would not rule out, of course, the potential value of

54 See supra notes 11-14 and accompanying text.

55 Cf. CHIPS, CHIPS Participants, last updated 14 August 2020, https://www. theclearinghouse.org/-/media/new/tch/documents/payment-systems/chips_ participants_revised_08-14-2020.pdf (listing banks from multiple continents as participants in the CHIPS clearing system).

56 Federal Reserve Board, Designated Financial Market Utilities, last updated 29 January 2015, https://www.federalreserve.gov/paymentsystems/designated_fmu_ about.htm; Congressional Research Service, 'Who Regulates Who? An Overview of the U.S. Financial Regulatory Framework', in CRS Reports, 10 March 2020, https://fas. org/sgp/crs/misc/R44918.pdf.

57 Federal Financial Supervisory Authority, Banks \& Financial Services Providers, updated 22 March 2016, https://www.bafin.de/dok/7857910. 
establishing an inter-governmental body, like the FATF, to try to produce bestpractice recommendations for international electronic funds transfers. ${ }^{58}$

\section{Conclusions}

As this chapter has shown, a significant portion of the currency transfers among businesses and financial institutions already occur digitally. The primary legal focus of enabling consumers to use central bank digital currency transfers on a day-to-day basis, as an alternative to cash, thus involves consumer protection.

This chapter assumes the feasibility of technology required to manage such a real time, low-cost, retail CBDC. This assumption appears to be realistic. The Clearing House, a banking association and payments company that is owned by large commercial banks, has created its Real Time Payments (RTP) network to facilitate real-time digital retail funds transfers. ${ }^{59}$ Though still in the planning stages, the Federal Reserve is working on its own interbank real-time funds transfer service. ${ }^{60}$ And China is already testing a retail CBDC in four cities. ${ }^{61}$

\section{References}

Bank for International Settlements (BIS), Annual Economic Report 2020, 30 June 2020, https://www.bis.org/publ/arpdf/ar2020e.htm

Patrycja Beniak, 'Central Bank Digital Currency and Monetary Policy: A Literature Review', in MPRA Papers, No. 96663, 26 October 2019, p. 2, https://mpra.ub.uni-muenchen.de/96663

Spencer Bokat-Lindell, 'Can We Trust Facebook to Run a Bank?', in The New York Times, 24 October 2019, https://nyti.ms/32JdwNz

Jonathan Cheng, 'China Rolls Out Pilot Test of Digital Currency', in The Wall Street Journal, 20 April 2020, https://www.wsj.com/articles/ china-rolls-out-pilot-test-of-digital-currency-11587385339

58 Cf. supra notes 37-39 and accompanying text (discussing FATF recommendations for combating money laundering, terrorist financing, and other related threats to the integrity of the international financial system).

59 CHIPS website: Real Time Payments, https://www.theclearinghouse.org/paymentsystems/rtp.

60 See supra note 17 and accompanying text.

61 Jonathan Cheng, 'China Rolls Out Pilot Test of Digital Currency', in The Wall Street Journal, 20 April 2020, https://www.wsj.com/articles/china-rolls-out-pilot-test-ofdigital-currency-11587385339. See also the chapter by Jan Knoerich in this volume. 
Barkley Clark and Barbara Clark, The Law of Bank Deposits, Collections and Credit Cards, 3rd ed., Boston, Warren, Gorham \& Lamont, 1990

Clearing House Interbank Payments System (CHIPS), Public Disclosure of Legal, Governance, Risk Management, and Operating Framework, June 2020, https://www.theclearinghouse.org/-/media/new/tch/documents/paymentsystems/chips_public_disclosure_june_2020.pdf

Committee on Payments and Market Infrastructures, 'Central Bank Digital Currencies', in CPMI Papers, No. 174 (12 March 2018), https://www.bis.org/ cpmi/publ/d174.htm

Committee on Payment and Settlement Systems, 'The Role of Central Bank Money in Payment Systems', in CPMI Papers, No. 55 (12 August 2003), https://www.bis.org/cpmi/publ/d55.htm

Congressional Research Service, 'Who Regulates Who? An Overview of the U.S. Financial Regulatory Framework', in CRS Reports, 10 March 2020, https://fas.org/sgp/crs/misc/R44918.pdf

Anton N. Didenko et al., 'After Libra, Digital Yuan and COVID-19: Central Bank Digital Currencies and the New World of Money and Payment Systems', in UNSW Law Research Series, No. 65/2020 (30 September 2020), https://ssrn.com/abstract=3622311

Francis J. Facciolo, 'Unauthorized Payment Transactions and Who Should Bear the Losses', in Chicago-Kent Law Review, Vol. 83, No. 2 (April 2008), p. 605631, https://scholarship.kentlaw.iit.edu/cklawreview/vol83/iss2/6

Federal Trade Commission, FTC Imposes $\$ 5$ Billion Penalty and Sweeping New Privacy Restrictions on Facebook, 24 July 2019, https://www.ftc.gov/node/ 1536925

Carl Felsenfeld, 'The Compatibility of the UNICTRAL Model Law on International Credit Transfers with Article 4A of the UCC', in Fordham Law Review, Vol. 60, No. 6 (1992), p. 53-75, https://ir.lawnet.fordham.edu/flr/ vol60/iss6/4

Financial Action Task Force (FATF), The FATF Recommendations. International Standards on Combating Money Laundering and the Financing of Terrorism \& Proliferation, June 2019, http://www.fatf-gafi.org/publications/ fatfrecommendations

Benjamin Geva, 'Payment Transactions under the E.U. Second Payment Services Directive-An Outsider's View', in Texas International Law Journal, Vol. 54, No. 2 (2019), p. 211-243, https://digitalcommons.osgoode.yorku.ca/ scholarly_works/2718

Benjamin Geva, 'Virtual Currencies and the State', in Just Money, 22 April 2020, https://wp.me/paGDrD-10W 
Charles M. Kahn and William Roberds, 'The Design of Wholesale Payments Networks: The Importance of Incentives', in Federal Reserve Bank of Atlanta Economic Review, Vol. 84, No. 3 (1999), p. 30-39, https://www.frbatlanta. org/research/publications/economic-review/1999/q3/vol84no3_design-ofwholesale-payments-network.aspx

Natasha Lomas, 'Libra, Facebook's Global Digital Currency Plan, Is Fuzzy on Privacy, Watchdogs Warn', in TechCrunch, 5August 2019, https://techcrunch. com/?p=1864705

Ralph E. McKinney et al., 'The Evolution of Financial Instruments and the Legal Protection Against Counterfeiting: A Look at Coin, Paper, and Virtual Currencies', in Journal of Law, Technology \& Policy, No. 2 (2015), p. 273-313, http://illinoisjltp.com/journal/wp-content/uploads/2015/12/McKinney.pdf

Lily Hay Newman, 'How Hackers Pulled Off a \$20 Million Mexican Bank Heist', in Wired, 15 March 2019, https://www.wired.com/story/mexico-bank-hack

Morgan Ricks, John Crawford and Lev Menand, 'FedAccounts: Digital Dollars', in George Washington Law Review, forthcoming (15 April 2020), https://ssrn. com/abstract $=3192162$

Mark Sneddon, 'The Effect of Uniform Commercial Code Article 4A on the Law of International Credit Transfers', in Loyola of Los Angeles Law Review, Vol. 29, No. 3 (April 1996), p. 1107-1135, https://digitalcommons.lmu.edu/ llr/vol29/iss3/11

Karen Yeung, 'What Is China's Cryptocurrency Alternative Sovereign Digital Currency and Why Is It Not Like Bitcoin?', in South China Morning Post, 13 May 2020, https://www.scmp.com/economy/china-economy/article/ 3083952/what-chinas-cryptocurrency-sovereign-digital-currency-and-why 
Franco Passacantando

\section{Chapter 5: The Digital Euro: Challenges and Opportunities}

Like other central banks, the European Central Bank (ECB) has been working on introducing a digital currency. While a decision has not yet been made, a report has been presented for consultation on the various problems and issues that need to be addressed before launch. ${ }^{1}$ The European Commission has also presented new draft regulations in the areas of digital finance and payments. All these moves are intended to facilitate digital innovation in Europe, and to improve the quality and costs of payment services. At the same time, there is a clear need to preserve the monetary integrity of the eurozone at a time when digital payment systems being launched by foreign central banks and big technology firms could seize a significant share of the domestic market.

The development of the new currency is of particular strategic importance to the $\mathrm{ECB}$, as it will further the process of integrating the eurozone payment system, which has already led to the introduction of TARGET 2 (T2) and TARGET 2 Securities (T2S) for the settlement of interbank payments and security transactions. It could also reinforce its role as a catalyst of EU market integration. The implementation of a digital currency, however, would face several challenges, given the highly innovative nature of the instrument and the fragmentation of the payment systems and capital markets in Europe.

This chapter will first discuss the implications of the digital transformation of payment systems for central banking. It will then briefly analyse how the payment system landscape in Europe is evolving. After that it will describe the main features of the digital currency proposed by the ECB and the place it would occupy in that landscape. Next, it will present the main problems and risks associated with the introduction of a digital euro, given the unique features of the European financial system, and will lay out measures and policies that could mitigate these risks. ${ }^{2}$

1 European Central Bank (ECB), Report on a Digital Euro, Frankfurt am Main, ECB, October 2020, https://www.ecb.europa.eu/euro/html/digitaleuro-report.en.html.

2 The author thanks Angela Caporrini, Claudio Impenna and Maria Iride Vangelisti for their comments. The usual disclaimer applies. 


\subsection{Digital currencies and central banking}

The evolution of payment systems has been one of the main drivers of the evolution of central banking. ${ }^{3}$ Technological innovations in the payment system and the growing familiarity of the public with digital instruments have not only changed the way central banks operate but have also affected some of their core functions and institutional features.

The first important change is the role central banks play as providers of cash, the most widely used medium of exchange by the public. ${ }^{4}$ It is a particularly popular instrument because it guarantees anonymity and has the status of legal tender, so it cannot be refused when presented to discharge a monetary obligation. ${ }^{5}$ Banknotes also ensure instant payment, unlike cheques or money orders and their value is risk free because they are a liability of safe institutions, central banks. ${ }^{6}$ Their purchasing power is in principle preserved even if used as a store of value because central banks have a special mandate to prevent the value of money being eroded by inflation. ${ }^{7}$ The status of banknotes as a risk-free, widely

3 Curzio Giannini, The Age of Central Banks, Cheltenham/Northampton, Edward Elgar, 2011.

4 A payment medium is a financial asset used to discharge obligations in transactions between two parties. A payment instrument is a device or procedure used to mobilise the payment medium. Cash refers both to coins and banknotes. In some countries, banknotes are issued by central banks while coins are minted by the state or government agencies. Banknotes are both a payment medium and a payment instrument, while in the case of bank money bank deposits are the medium and checks, demand drafts and the like are the instruments.

5 The concept of legal tender is not applied uniformly across European countries. The most common interpretation is that it cannot be refused as a means to execute a payment. In countries such as Germany, Finland, the Netherlands and Ireland, 'the legal tender provisions refer to the fulfillment of an essential part of a contract already concluded and do not amount to an obligation to conclude a contract allowing for cash payments'. See Euro Legal Tender Expert Group (ELTEG), Definition, Scope and Effects of Legal Tender of Euro Banknotes and Coins, Brussels, 2010, p. 6, http://ec.europa.eu/ economy_finance/articles/euro/documents/elteg_en.pdf.

6 With banking instruments, there is a lag between the time the payment is made and the time the money is actually transferred to the receiver's account. The longer the interval between the payment and settlement, the greater the likelihood that some payments will not be successfully completed, whether because of technical problems, liquidity issues, insufficient funds of the counterpart (the so-called counterparty risk) or, in extreme cases, the sudden, unexpected failure of a participant. This creates credit risk, liquidity risk and systemic risk.

7 It also embeds technical features which limit the risks of counterfeiting. 
accepted payment medium has historically given central banks a monopoly in the retail payments market.

A number of innovations are taking place in the area of retail payments that have the potential to challenge this state of affairs. The one with the greatest implications is the 'stablecoin' Libra, which may not be as risk-free as a central bank liability, but would be backed by a mix of reasonably safe assets with low volatility and stable purchasing power. Furthermore, like cash, it could be used even by those who do not have bank accounts, and would allow instant transfer of money. ${ }^{8}$ With respect to cash it could make transactions much easier for consumers and merchants. ${ }^{9}$ The role of cash as legal tender could become less relevant with the growth of new instruments guaranteeing immediate transfer of financial assets.

The second important change is in the role central banks play with respect to the banking system. Currently only supervised institutions, mostly commercial banks, can open accounts with central banks. The provision of central bank money to banks implies a vertical 'pyramid-like' structure of the monetary sector, in which commercial banks are intermediaries in the payments made by private customers and central banks serve as settlement agent for payments among banks. This structure gives central banks special responsibilities with regard to the whole system and justifies the catalytic and operational roles most of them play with respect to payment systems. ${ }^{10}$ It also gives them the possibility to exercise oversight over the functioning of the payment system to prevent security breaches or other forms of malfunctioning. In a possible future configuration, tech companies could use their platforms to create parallel systems as alternatives to traditional systems. Their capacity to reach a vast number of clients would put the 'pyramid under siege. ${ }^{11}$ Central banks' capacity

8 European Central Bank (ECB), Implications of Digitalisation in Retail Payments for the Eurosystem's Catalyst Role, Frankfurt am Main, ECB, July 2019, https://op.europa.eu/ s/or2s.

9 Another category of entrants are the providers of digital wallets which are based on bank money but allow users to make instant payments on their bank accounts, using their phones or other portable electronic devices. For an overview and assessment of the instruments offered by big tech companies see Nicola Bilotta and Simone Romano, eds, The Rise of Tech Giants. A Game Changer in Global Finance and Politics, Bern, Peter Lang, 2019.

10 Many, central banks, like the Eurosystem, directly operate the interbank payment system (the T2 system in Europe). Others do not directly operate the system but have special powers of supervision and regulation over privately operated systems.

11 Curzio Giannini, The Age of Central Banks, cit. 
not only to ensure the well functioning of the payment system but also to regulate the money in circulation or to influence credit conditions could be weakened, especially if the new players would have access to global markets for their funding needs.

The response to these challenges requires first of all a regulatory and supervisory framework extended to the new entrants in the payment system. A parallel evolution would be for central banks to offer the public a central bank digital currency (CBDC), a central bank liability that can be mobilised electronically. Even if done indirectly, by leaving the technical interface with final customers to commercial banks, it would still mean a generalised use of a central bank liability.

The substitution of bank deposits with central bank money could increase the financing capacity of central banks and reduce that of commercial banks. This could have various implications. First of all central banks would have to change their lending and investment practices, which are at present motivated mainly by monetary policy considerations and are designed to shield them from political pressures to finance the state or certain sectors of the economy.12 Second, it could become more expensive for commercial banks to lend to the private sector, because the banks would have to pay higher interest rates on their deposits or rely more on capital markets, in direct competition with other financial intermediaries. Finally there is a fear that a central bank currency alternative to bank deposits could amplify financial instability, because it could facilitate the transfer of funds from bank deposits to central bank accounts during crises.

As it will be argued, these issues need to be carefully considered for the case of a digital euro, given the bank-based model of the European financial system, the absence of developed and integrated capital markets and the risks of banking systems' fragmentation during crises.

\subsection{The changing retail payments landscape in Europe}

The reason why the central banks of some countries, such as Sweden or China, have made more progress in their digital currency projects is that in those countries the use of cash is rapidly declining and large internet providers are gaining

12 The principle of central banks' autonomy states that central banks should refrain from financing the state's budget deficits and from conducting commercial business with non-bank customers. To prevent misallocation of resources, commercial banking and central banking should be clearly separated. 
a dominant position in the monetary system. In Europe, the situation is very different. First, a recent rapid increase in the availability of alternative instruments has been paralleled by continued growth of cash use. Second, the use of cards in the eurozone is not as widespread as in countries like the United States or the United Kingdom, and varies greatly from country to country. Third, the pace of innovation is accelerating, but it is mostly at the local or national levels. Finally banks' most promising initiatives, such as those in the area of instant payments, are still highly fragmented along national lines. The risk is that innovative new players will operate mostly at the local level while global players will dominate the Europe-wide market, as has happened with major credit card brands.

Cash is still the preferred instrument for small transactions and it is increasingly being hoarded amid decreasing interest rates and higher uncertainty. ${ }^{13}$ The situation however is very different from country to country. Austria, Germany, Italy and Ireland have a marked preference for cash, while in the Netherlands its use is rapidly declining. Beyond the eurozone, cash is close to disappearing in Sweden. ${ }^{14}$

The use of card payments in the eurozone is far less widespread than in other regions of the world. In 2016, it amounted to 15.6 per cent of combined gross domestic product, in contrast to 45.5 per cent in the UK and 31.7 per cent in the US. ${ }^{15}$ The use of cards varies considerably within the eurozone. In 2018, the number of payments by card per capita ranged from between 332 in Finland and 275 in the Netherlands, to around 64 in Italy and Germany. ${ }^{16}$

There are however signs of accelerating change, especially because the COVID-19 crisis has given a major impetus to the use of online transactions

13 Roberto Rinaldi, 'Cash', in Luiss SEP Working Papers, No. 9/2019 (24 May 2019), https:// sep.luiss.it/node/2437. The ratio of cash to GDP is higher in the eurozone than in the US, but in both economies has been increasing - between 2005 and 2017 it has gone from 6.3 to 8.2 per cent in the United States and from 7.1 to 10.7 per cent in the eurozone - mainly because of the reduction of interest rates and other macroeconomic factors.

14 European Commission, A New Vision for Europe's Capital Markets. Final Report of the High Level Forum on the Capital Markets Union, June 2020, https://europa.eu/ !gU33Hm; Roberto Rinaldi, 'Cash', cit.

15 BIS datareportedbyFerdinandoGiugliano, 'EuropeIs Planning Its Very OwnE-Currency', in Bloomberg Opinions, 16 November 2020, https://www.bloomberg.com/opinion/articles/2020-11-16/christine-lagarde-s-ecb-is-planning-its-very-own-e-currency.

16 Not including Luxembourg which, with 5,276 card payments per year is a clear outlier. Banca d'Italia, Appendice alla Relazione annuale sul 2019, 29 May 2020, p. 101, https:// www.bancaditalia.it/pubblicazioni/relazione-annuale/2019/index.html. 
and contactless instruments. Consumers prefer them for safety reasons and merchants and business owners view faster payments as a way to reduce the settlement risk in a deteriorating business environment.

The crisis has accelerated the technological innovation that was already taking place in fintech, and in the area of electronic money, mostly at the local level. ${ }^{17}$ A recent ECB report shows the majority ( 45 per cent) of fintech initiatives in the area of retail payments are offered by local start-ups, while banks and banking associations come second with a third of the total. ${ }^{18}$ Start-ups have an especially significant share of cross-currency solutions, in which banks lag far behind. ${ }^{19}$ This trend has been encouraged by the second Payment System Directive (PSD2), which has allowed the co-existence of third-party providers and banks in the provision of payment and payment-related services.

Banks are responding, most notably by pushing for instant payments, but there is still considerable fragmentation along national lines. ${ }^{20}$ As the European Commission reports,

many citizens still face unacceptable refusals of cross-border SEPA Direct Debit transactions ('IBAN [International Bank Account Number] discrimination'). This means that they cannot use IBANs from a different country to make a payment. Payees are still often unwilling or not technically able to accept cross-border SEPA Direct Debits. ${ }^{21}$

In 2017 the European Payments Council (EPC) developed a scheme to enable instant money transfers without exchanging IBANs. However participation has been rather limited and the European Commission is considering making it compulsory. ${ }^{22}$

17 Oxera Consulting, The Competitive Landscape for Payments: A European Perspective, March 2020, https://www.oxera.com/?p=131237.

18 ECB, Implications of Digitalisation in Retail Payments for the Eurosystem's Catalyst Role, cit.

19 'As the current correspondent banking model is widely perceived as profitable and constitutes a relatively high market barrier, current players may have little incentive to devise new fintech solutions in this field in the absence of competitive pressure. Therefore, in this domain we can identify fintech start-ups as real competitors to banks.' Ibid., p. 15.

20 Many banks are responding by creating partnerships and joint products with fintech companies and provider of electronic money.

21 European Commission, On a Retail Payments Strategy for the EU (COM/2020/ 592), 24 September 2020, p. 10, https://eur-lex.europa.eu/legal-content/EN/TXT/ ?uri=CELEX:52020DC0592.

22 The participation has been insufficient either because of their voluntary nature or because the alternative of the IBAN is the QR-codes which are not standardised at 
Another trend is the growing popularity of services offered by big players with a strong customer base, mainly driven by their vast social or commercial networks. For example, PayPal has a strong presence in Germany and in Italy where it manages 52 per cent and 32 per cent respectively of all e-commerce. ${ }^{23}$ Another possible development is greater penetration into financial services by big tech companies with well-established digital interaction with customers. The most prominent example is that of Amazon, which has created its own online payment platform (Amazon Payments), open to customers and merchants. ${ }^{24}$

In conclusion, in the European Union there is rapid innovation at the local level, but there is a concrete risk that the pan-European market for digital payments for digital payments will be taken over by global players.

\subsection{The central bank digital euro}

These trends in the European payments landscape help explain the motivation of the ECB. At this stage the ECB has presented a study, open for consultations, which could prepare the ECB to deploy a digital euro 'should the need arise'. In mid-2021 the European System of Central Banks (Eurosystem) will decide whether to implement the project.

\section{Motivations}

Most commentators have focused on the 'defensive' motivation. Indeed the ECB has stressed the need to preserve the integrity of the monetary system which, as mentioned in the previous paragraph, could be challenged by global players. These could be operators of big Internet platforms, dominant card schemes or stablecoin suppliers. A recent G7 report has highlighted several risks related to the issuance of stablecoins. ${ }^{25}$ However, given Facebook's ability to reach millions,

EU level. In addition, the providers of mobile devices limit the access to Near Field Communication technology. Ibid., p. 7.

23 Oxera Consulting, The Competitive Landscape for Payments: A European Perspective, cit.

24 ECB, Implications of Digitalisation in Retail Payments for the Eurosystem's Catalyst Role, cit.

25 They could lead to monetary substitution and financial instability, and also weaken countries' ability to execute monetary policy. From a regulatory point of view there would be problems in assessing their compliance with anti-money laundering (AML) and counter-terrorism financing rules. Instead of fostering competition, they may end up weakening it. See G7 Working Group on Stablecoins, 'Investigating the Impact of Global Stablecoins', in CPMI Papers, No. 187 (18 October 2019), https://www.bis.org/ cpmi/publ/d187.htm. 
if not billions, of customers, its stablecoin Libra could rapidly gain popularity with the public. Another challenge could come from the digital currency issued by 'early mover' foreign central banks, which could attract domestic users.

However, another important motivation is to overcome the existing fragmentation and to recover the ECB's catalytic role in promoting Europe-wide initiatives in a market that is highly dynamic, but mostly at the local level. At the same time, a digital euro could foster the international role of the euro or, in the ECB's language, support the 'strategic autonomy' of the European Union. ${ }^{26}$

Another important consideration would be improvement in the transmission mechanism of monetary policy to the real economy. While deposit rates now react very slowly to changes in reference rates, with a remunerated digital currency, changes in central bank policy rates would be directly reflected in the rates households and businesses receive.

The ECB has clarified that the new central bank currency would complement, but not replace cash. This is inevitable, because there are an estimated 30 million adults in the EU who do not have bank accounts.

Furthermore, the ECB has stressed that the new currency would complement private digital instruments and enhance competition, rather than suppressing it by creating a public monopoly. 'The prospect of central bank initiatives to issue a digital euro should neither discourage nor crowd out private solutions for efficient digital retail payments in the euro area. ${ }^{27}$ The ECB has gone so far as to state that a digital euro might not be issued if alternative solutions become available.

\section{Main features}

The CBDC would be a central bank liability accessible not just to banks, but to all citizens and firms. Unlike cash, it would function both as a means of payment and as a remunerated financial asset.

Technical details have yet to be specified regarding two main issues. The first is whether it should be a bearer instrument similar to cash or an account-based system similar to electronically accessible bank deposits (or both). The second is whether this access should be direct, or intermediated by banks and other financial institutions.

26 For an overview of the benefits of the status of international currency, and of why the euro has not yet attained it, see Stefano Micossi, 'An International Role for the Euro?', in Luiss SEP Policy Briefs, No. 37/2020 (2 October 2020), https://sep.luiss.it/node/3132.

27 ECB, Report on a Digital Euro, cit., p. 8. 
The bearer payment tool could operate by means of an instrument - a 'token' to be used offline. It would represent the logical successor to the banknote and could require the storage of a certain amount of euro in a digital wallet which would be replenished through an online account. The offline instrument, like a digital wallet, would need online access to add funds in the wallet. ${ }^{28}$ Alternatively, the bearer instrument could operate through an internet connection with the ECB accounts available at the points of sale. It would be free of charge for basic use and would be a 'simple, risk-free and trusted digital means of payment, accepted throughout the euro area'. Depending on its technical specifications, the instrument could also be used by those who currently do not have bank accounts.

In principle the ECB could open an account directly with all the users of the digital euro. It would however be very technically challenging and also not desirable because of the risks implied. The model that the ECB, like most central banks, is considering for the account-based digital euro is a two-tier system in which banks have direct access to central bank accounts and manage the interface with the customers' accounts with the central bank. In this way banks could retain their relationships with customers for value-added services.

A possibility would be to use the instant payment settlement system launched in November 2018 as an extension to retail payments of the Target 2 system. In its current configuration the TARGET Instant Payment Settlement (TIPS) system would allow money to be credited to recipients' account within seconds and could potentially settle 500 payments per second (some 43 million transactions a day) in central bank money. Unlike T2, it could also be a multi-currency system. ${ }^{29}$

\section{Anonymity and privacy}

A web-based central bank digital euro would have to comply with current European regulations and legal obligations regarding money laundering. For large-value transactions in particular, the regulation makes the identification of users compulsory. Furthermore, the ECB intends to impose restrictions on some

28 It will be similar 'to the current coexistence of (online) commercial bank deposits and' (physical) cash that can be withdrawn from bank accounts via ATMs, the digital euro could be made available online and amounts loaded onto a physical device for offline use'. Ibid., p. 34-35.

29 Outside the eurozone, the Riksbank has shown interest in using TIPS for its digital currency project and has announced that it will begin to settle instant payments in Swedish krona starting from May 2022. 
categories of users, such as non-eurozone residents, and on some operations. To do this it will need to be able to identify users. The offline bearer instrument could remain anonymous.

The ECB stresses that the digital euro would have to respect the right to privacy. As stated by Panetta, 'A digital euro would increase privacy in digital payments thanks to the involvement of the central bank, which - unlike private suppliers of payment services - has no commercial interests related to consumer data. ${ }^{30}$ It also envisages an independent, neutral third party that could audit the system to monitor compliance with privacy rules.

\subsection{Main challenges}

As already mentioned, the introduction of a CBDC would have profound implications for commercial banks as well as for the way central banks operate and pursue policy objectives. For the digital currency of a monetary union, the complexities would be compounded by the differences in payment habits and banking structures in member countries.

\section{Disintermediation of banks}

As mentioned, one major concern about CBDCs is that they could lead to bank disintermediation, because the public would substitute bank deposits with CBDCs. To retain funding capacity, banks would have to offer higher interest rates, which could in turn force them to either increase the cost of loans or reduce the volume of lending. However, this outcome may not be very significant quantitatively and, to a certain extent, might even be desirable.

Only some categories of deposits, mostly sight deposits, are likely to migrate to the central bank, and banks would still retain savings accounts and could increase their reliance on wholesale funding. ${ }^{31}$

The availability of an alternative medium for sight deposits would also incentivise banks to offer more innovative payment services and enrich their financial product offerings. A number of banks are already offering value added services

30 Fabio Panetta, A Digital Euro for the Digital Era, Introductory Statement at the ECON Committee of the European Parliament, Frankfurt am Main, 12 October 2020, https:// www.ecb.europa.eu/press/key/date/2020/html/ecb.sp201012_1 1d14637163.en.html.

31 See Fabio Panetta, '21st Century Cash: Central Banking, Technological Innovation and Digital Currencies', in SUERF Policy Notes, No. 40 (August 2018), https://www. suerf.org/policynotes/3251/21st-century-cash-central-banking-technologicalinnovation-and-digital-currencies. 
in addition to payment services including pre-transaction and post-transaction services or credit related services. ${ }^{32}$

Banks would also have to gradually move away from the classic intermediation model, based on a maturity mismatch between assets and liabilities, wherein they finance long-term investments while serving investors' short-term liquidity needs. On the one hand they could offer or intermediate a wider range of financial and savings instruments to the public. On the other they could help corporate clients gain better access to capital markets, or complement the products they offer with those available in the capital markets. A review of the regulations in some specific sectors, such as those regarding securitisation, could facilitate this process.

This would be a desirable development in Europe given the abnormal share of banks in the financial system and the well-known shortcomings of bank-based financial systems, especially at time of crisis. According to some estimates the ratio of total bank assets to GDP is three times bigger in the EU than in the United States. ${ }^{33}$ Securitisation would be a particularly useful tool for banks, allowing them to transfer illiquid loans to investors. ${ }^{34}$ Currently, securitisation represents only 3 per cent of GDP in the EU-27, as opposed to 12.5 per cent in the United States and 12 per cent in the UK. ${ }^{35}$

Some technical features of the new currency could also be designed for a smooth disintermediation. One possibility would be for the ECB to introduce quantitative limits for different categories of customers and differentiated interest rates. For example, Bindseil and Panetta suggest setting a limit of up to

32 Pre-transaction services include identification of parties, management of payment data, choice of payment instruments, electronic invoicing and ex-ante compliance process. Post-transaction services relate to the provision of electronic receipts, management of complaints and cancellations, and additional commercial offers. See ECB), Implications of Digitalisation in Retail Payments for the Eurosystem's Catalyst Role, cit.

33 According to Langfield and Pagano, the total assets of banks in the EU amounted to 334 per cent of the GDP in 2013, as opposed to the 196 per cent for Japanese banks and 86 per cent for US banks. Converting the US figure to international accounting, the size of the US banking system would reach 115 per cent of US GDP, still only about a third of the size of Europe's banking system. See Sam Langfield and Marco Pagano, 'Bank Bias in Europe: Effects on Systemic Risk and Growth', in ECB Working Paper Series, No. 1797 (May 2015), https://www.ecb.europa.eu/pub/pdf/scpwps/ecbwp1797. en.pdf.

34 Securitisation implies the repackaging of these assets and dividing the resulting security into tranches with different risk profiles.

35 European Commission, A New Vision for Europe's Capital Markets, cit., p. 57. 
3,000 euro per capita, which would cover the average monthly net income of eurozone households. ${ }^{36}$ The interest rate applied to this amount would be zero, while for larger amounts, which would be reserved for categories of users other than households, interest would be lower, or even negative, to discourage holding digital currency for investment purposes.

\section{Expansion of central banks' balance sheets}

If a CBDC were meant mainly to replace banknotes, the size and composition of the central bank's balance sheet would not change substantially. However, it could greatly increase if non-residents shifted part of their portfolios into the national CBDC or if the public moved commercial bank deposits held for transaction purposes to the CBDC. ${ }^{37}$ This hardly seems to be a problem at a time when central bank's balance sheets are bulging. However, changes in lending and investment policies of central banks may have important institutional implications. Certainly, central banks could not take over the function of lenders to the private sector, which would lead to misallocation of resources and crowding out of a key function of commercial banks. ${ }^{38}$

The most immediate possibility would be of the ECB using the additional funds to increase loans to banks. This solution would preserve the separation of roles between central banks and commercial banks, but could be problematic from several points of view. First, the collateral banks could offer, especially in its loan component, could not be of the high quality that the ECB usually requires. Second, it would represent an important change in the ECB's current lending policies, which are exclusively aimed at fulfilling the ECB's monetary and financial stability objectives. Current long-term maturities - up to three years for long-term repo operations or LTROs - are justified only by monetary policy considerations, i.e. the need to avoid a prolonged deviation from the inflation target.

36 'For corporates (financial non-banks and non-financials) the tier one allowance could be set to zero, or it might be calculated to be proportional to a measure of their size and, thus, presumed payment needs. Foreigners could be allowed to hold CBDC, but should not have any tier one allowance.' See Ulrich Bindseil and Fabio Panetta, 'Central Bank Digital Currency Remuneration in a World with Low or Negative Nominal Interest Rates', in VoxEU, 5 October 2020, https://voxeu.org/node/66304.

37 The exception is the component of these assets represented by banks' liquidity in the form of banks' reserves with the central bank.

38 Agustín Carstens, The Future of Money and Payments, Speech at the Central Bank of Ireland, 2019 Whitaker Lecture, Dublin, 22 March 2019, https://www.bis.org/speeches/ sp190322.htm. 
Finally, complex conflicts of interests would arise if the ECB were to become a 'structural' long-term investor in the banks it supervises.

The other asset the Eurosystem could acquire are government securities. Currently, the Eurosystem's portfolio includes a huge volume of public bonds which have been acquired almost exclusively as a result of quantitative easing operations rather than to finance states, which it is not allowed to do. It could also increase its investments in corporate bonds, but given the lack of depth of European capital markets, this could excessively reduce the quantity of corporate bonds held in private banks. ${ }^{39}$ A deep securitisation market could greatly help in this respect, because it would allow the ECB to subscribe to a less risky and highly liquid tranche of securitised assets.

Overall, this problem does not seem to be insurmountable, especially if limits were imposed on the amount of the digital currency the public could access. Probably the best option for the central bank would be a proper combination of all the previously mentioned options, following some transparent rules of diversification and principles of market neutrality. Furthermore, from this point of view, the development of deeper and more highly integrated capital markets would be crucial for Europe.

\section{Financial instability and volatility of capital flows.}

Another concern is that the digital euro could increase the risk of bank runs. During a confidence crisis, bank customers would no longer have to form long queues to withdraw cash at bank branches or ATMs - they could do it electronically from the comfort of home. This possibility already de facto exists for large value deposits, which can at any time be converted to Treasury bills or other low-risk assets. This would become available to the public at large, and for small-value deposits which could be easily converted into risk-free CBDC.

A shift from bank deposits into cash is not a remote possibility. It happened in 2008, when flights from bank deposits peaked after the collapse of Lehman Brothers and remained high during the 2010-13 sovereign debt crisis. ${ }^{40}$

39 It could also increase investments in non euro area bonds but this would expose the ECB to the risk of exchange rate volatility. See Santiago Fernández de Lis and Olga Gouveia, 'Central Bank Digital Currencies: Features, Options, Pros and Cons', in BBVA Working Papers, No. 19/04 (March 2019), https://www.bbvaresearch.com/en/ publicaciones/central-bank-digital-currencies-features-options-pros-and-cons.

40 Roberto Rinaldi, 'Cash', cit. 
Quantitative limits on the use of the CBDC or its remuneration could limit this risk. The ECB believes that a variable remuneration system could be used to reduce the conversion of bank deposits into CBDC at times of crisis. ${ }^{41}$ However a rate change of this kind would be a very sensitive instrument to use during banking crises because of the signal it would send to the markets about the concerns of the central bank, based on the granular information at its disposal, which is not always publicly available. ${ }^{42}$

At the same time, it is very unlikely that a run on banks would become generalised across the eurozone. Most likely it would affect either individual institutions or the entire banking systems of some member countries. In the former case, strengthened traditional instruments of lending of last resort could be sufficient. In the latter case it would certainly be very difficult to reduce the remuneration of the digital currency in the entire eurozone in response to financial instability in a few member countries.

The exposure of the eurozone to the risk of fragmented banking crises is a well-known problem, and policy actions to address it are well known, but there is no consensus on how to implement them. They include completing the banking union, in particular introducing cross-border deposit insurance, a sustainable crisis resolution mechanism for banks and a stronger public backstop in case of a systemic crisis. Because of the possible impact on financial instability, the creation of a digital euro requires further progress on all these fronts.

\section{Reputational risks}

Perhaps the main risks for the ECB would be that the new currency will not be successful among the public. Countries that are more cash-oriented would continue to use cash, while countries that already use digital instruments would continue to use them, because of the value-added services they offer with respect to the CBDC and the less stringent quantitative limitations. This risk will be higher the longer it will take to actually implement the project, because in the current

41 A variable rate could also help limit sudden inflows of money, which could cause an undesirable appreciation of exchange rates. It has been shown that the introduction of CBDCs facilitates international arbitrage that links together interest rates, the exchange rate and the remuneration of the CBDC. See Massimo Minesso Ferrari, Arnaud Mehl and Livio Stracca, 'The International Dimension of a Central Bank Digital Currency', in VoxEU, 12 October 2020, https://voxeu.org/node/66335.

42 A similar problem would arise with changes in the quantitative limits which would raise the same concerns as a reintroduction of capital controls, with all the problems of enforceability and circumvention that this would imply. 
dynamic environment the first mover, be it a private entity or a foreign central bank, could acquire a lasting dominant position.

Another important risk is the possible breakdown or malfunctioning of the IT systems on which the CBDC is built. Events of this kind unfortunately do occur even in the best regulated and supervised market infrastructures, like stock exchanges, and clearing or settlement networks. This would have high reputational costs, because a sudden inability to use the currency, even for a few hours, would foster strong public resentment against the ECB. There is also the issue of whether the central bank could be held responsible for economic losses suffered by some users. Another problem could arise if the CBDC, at least the component covered by anonymity, were used for illegal activities like tax evasion, drug trafficking, money laundering, and financing terrorism.

A digital currency could also become a key target for cyberattacks because of its relevance to the economy of the entire eurozone. Terrorist groups or hostile nation-states could develop the capacity to use this as a warfare instrument or as a tool for extortion. Of course this risk would exist even with private systems, and a public entity like the Eurosystem would be better equipped to defend itself because of its role in the operation of major platforms like T2 or T2S. Nevertheless, such risks can never be completely eliminated. There would therefore be an obvious need to strengthen common deterrence tools in the eurozone, and develop a common intelligence pool that would collect intelligence gathered by the various member states.

To mitigate these risks, the construction of the new platform will require huge investments in technology. It would be important to clearly disclose whether the returns on these investments, including social benefits, justify those costs.

\section{Conclusion}

The new digital currency will be an opportunity to greatly improve the efficiency of the European payment system which, in its retail component, has been highly innovative but is still highly fragmented along national lines. It could also improve the transmission mechanism of monetary policy and the role of the euro as an international currency. The initiative is timely, because doing nothing would amplify the risk that the only Europe-wide digital payment schemes would be those offered by global private institutions or foreign central banks.

One of the main challenges will be limiting bank disintermediation. Although this risk has probably been overstated in the CBDC debate, it is a critical issue for Europe because of the high reliance on bank intermediation of European 
enterprises, especially the SMEs that form the bulk of the industrial sector in many member countries. Also the risks of instability should not be underestimated because the recent experience shows that when they materialize they result in fragmentation of banking markets along national borders. Whether the CBDC could exacerbate these risks requires further analysis, but at the same time it would not be easy to design measures to mitigate them, like variable interest rates on the $\mathrm{CBDC}$, whose impact would greatly differ from country to country.

The digital currency could be designed to facilitate a gradual adaptation of the banking system to the new environment. However, both the banking sector and the corporate sector will eventually have to increase their reliance on capital markets for funding needs. The ECB will also have to rely more on capital market instruments to diversify the investments of the additional funds which it will have at its disposal. The launch a digital euro, therefore, should not been seen in isolation from the efforts to remove the obstacles to the Capital Markets Union. The launch of the currency also needs to be complemented by the completion of the banking union, in order limit the risks of financial markets instability and strengthen the role of the euro as an international currency.

Perhaps the biggest risk is that the digital euro will not win over the public, because those who prefer cash will continue to use it and those used to innovative digital instruments will not abandon them. More than the legal tender status of the new currency, what will matter is the technical design, the protection of privacy, the ease of use, the perceived risks for users, the cost to the public of the new instrument and its timely implementation.

\section{References}

Itai Agur, Anil Ari, Giovanni Dell'Ariccia, 'Designing Central Bank Digital Currencies', in VoxEU, 19 May 2020, https://voxeu.org/node/65678

Banca d'Italia, Appendice alla Relazione annuale sul 2019, 29 May 2020, https:// www.bancaditalia.it/pubblicazioni/relazione-annuale/2019/index.html

Bank of Canada et al., Central Bank Digital Currencies: Foundational Principles and Core Features, Basel, Bank for International Settlements, October 2020, https://www.bis.org/publ/othp33.htm

Bank of England, Central Bank Digital Currency. Opportunities, Challenges and Design, A Discussion Paper, March 2020, https://www.bankofengland.co.uk/ paper/2020/central-bank-digital-currency-opportunities-challenges-anddesign-discussion-paper 
Nicola Bilotta and Franco Passacantando, 'Libra or Zuck-Coin? Risks and Opportunities of Facebook's Cryptocurrency, in IAI Commentaries, No. 19|43 (July 2019), https://www.iai.it/en/node/10586

Nicola Bilotta and Simone Romano, eds, The Rise of Tech Giants. A Game Changer in Global Finance and Politics, Bern, Peter Lang, 2019

Ulrich Bindseil and Fabio Panetta, 'Central Bank Digital Currency Remuneration in a World with Low or Negative Nominal Interest Rates', in VoxEU, 5 October 2020, https://voxeu.org/node/66304

Agustín Carstens, The Future of Money and Payments, Speech at the Central Bank of Ireland, 2019 Whitaker Lecture, Dublin, 22 March 2019, https:// www.bis.org/speeches/sp190322.htm

Committee on Payments and Market Infrastructures, 'Central Bank Digital Currencies', in CPMI Papers, No. 174 (March 2018), https://www.bis.org/ $\mathrm{cpmi} / \mathrm{publ} / \mathrm{d} 174 . \mathrm{htm}$

Euro Legal Tender Expert Group (ELTEG), Definition, Scope and Effects of Legal Tender of Euro Banknotes and Coins, Brussels, 2010, http://ec.europa.eu/ economy_finance/articles/euro/documents/elteg_en.pdf

European Central Bank (ECB), Implications of Digitalisation in Retail Payments for the Eurosystem's Catalyst Role, Frankfurt am Main, ECB, July 2019, https://op.europa.eu/s/or2s

European Central Bank (ECB), Report on a Digital Euro, Frankfurt am Main, ECB, October 2020, https://www.ecb.europa.eu/euro/html/digitaleuroreport.en.html

European Commission, A New Vision for Europe's Capital Markets. Final Report of the High Level Forum on the Capital Markets Union, June 2020, https:// europa.eu/!gU33Hm

European Commission, On a Digital Finance Strategy for the EU (COM/2020/ 591), 24 September 2020, https://eur-lex.europa.eu/legal-content/EN/TXT/ ?uri=CELEX:52020DC0591

European Commission, On a Retail Payments Strategy for the EU (COM/2020/ 592), 24 September 2020, https://eur-lex.europa.eu/legal-content/EN/TXT/ ?uri=CELEX:52020DC0592

Santiago Fernández de Lis and Olga Gouveia, 'Central Bank Digital Currencies: Features, Options, Pros and Cons', in BBVA Working Papers, No. 19/04 (March 2019), https://www.bbvaresearch.com/en/publicaciones/ central-bank-digital-currencies-features-options-pros-and-cons

Massimo Minesso Ferrari, Arnaud Mehl and Livio Stracca, 'The International Dimension of a Central Bank Digital Currency', in VoxEU, 12 October 2020, https://voxeu.org/node/66335 
G7 Working Group on Stablecoins, 'Investigating the Impact of Global Stablecoins', in CPMI Papers, No. 187 (18 October 2019), https://www.bis. org/cpmi/publ/d187.htm

Curzio Giannini, The Age of Central Banks, Cheltenham/Northampton, Edward Elgar, 2011

Ferdinando Giugliano, 'Europe Is Planning Its Very Own E-

Currency', in Bloomberg Opinions, 16 November 2020, https:/www.bloomberg.com/opinion/articles/2020-11-16/ christine-lagarde-s-ecb-is-planning-its-very-own-e-currency

Taiji Inui, Wataru Takahashi and Mamoru Ishida, 'A Proposal for an Asian Digital Common Currency', in VoxEU, 16 October 2020, https://voxeu.org/ node/66351

Sam Langfield and Marco Pagano, 'Bank Bias in Europe: Effects on Systemic Risk and Growth', in ECB Working Paper Series, No. 1797 (May 2015), https://www.ecb.europa.eu/pub/pdf/scpwps/ecbwp1797.en.pdf

Stefano Micossi, 'An International Role for the Euro?', in Luiss SEP Policy Briefs, No. 37/2020 (2 October 2020), https://sep.luiss.it/node/3132

Dirk Niepelt, 'Digital Money and Central Bank Digital Currency: An Executive Summary for Policymakers', in VoxEU, 3 February 2020, https://voxeu.org/ node $/ 65037$

Oxera Consulting, The Competitive Landscape for Payments: A European Perspective, March 2020, https://www.oxera.com/?p=131237

Fabio Panetta, '21st Century Cash: Central Banking, Technological Innovation and Digital Currencies', in SUERF Policy Notes, No. 40 (August 2018), https://www.suerf.org/policynotes/3251/21st-century-cash-central-bankingtechnological-innovation-and-digital-currencies

Fabio Panetta, A Digital Euro for the Digital Era, Introductory Statement at the ECON Committee of the European Parliament, Frankfurt am Main, 12 October 2020, https://www.ecb.europa.eu/press/key/date/2020/html/ecb. sp201012_1 1d14637163.en.html

Roberto Rinaldi, 'Cash', in Luiss SEP Working Papers, No. 9/2019 (24 May 2019), https://sep.luiss.it/node/2437 


\section{P.M.T. Masela \\ Chapter 6: Digital Currency Initiatives on the African Continent}

Financial technology (fintech) developments present opportunities that may be leveraged by regulatory authorities and the financial sector to enhance financial service offerings. In leveraging these opportunities, regulatory authorities also guard against possible risks that these developments may present.

The focus of the authorities is mainly on how these developments support achievement of public policy objectives. In this process, it is imperative that the focus should not be on the new technologies but rather on new business models that will enhance the fulfilment of the needs of the business and communities that consume financial services.

It should therefore not be surprising that a number of central banks have established fintech units or programmes within their jurisdictions or that these have been undertaken in collaboration with other relevant regulatory authorities. In South Africa, although the central bank has established a fintech programme within the bank, a collaborative structure known as the Intergovernmental Fintech Working Group (IFWG) was also established, comprising members from the National Treasury, the central bank, the financial sector conduct authority, the anti-money laundering authority, the national credit regulator and the revenue authority. In the 15-member regional bloc of the Southern African Development Community (SADC), the committee of central bank governors has also established a multidisciplinary regional working group that focusses on specific initiatives in fintech. Several central banks in Sub-Saharan Africa have also launched initiatives focusing on this area of work with some specifically dealing with central bank issued digital currencies (CBDC) and addressing policy positions on crypto-assets/currencies.

Many discussions around retail CBDC today revolve around ambitious policy-focused use cases. Most recently, in the face of potential competition from a growing assortment of innovative private crypto-assets like Bitcoin and stablecoins such as Facebook's Libra, central bankers around the world have been consumed with the possibility of implementing CBDC as a solution to regain control over their national money supply. ${ }^{1}$

1 Michaela Allen and Barry Cooper, 'CBDC-The Next Frontier of Mobile Money?', in Central Bank Payments News, Vol. 3, No. 3 (March 2020), p. 22-25, https://cenfri.org/ articles/cbdc-the-next-frontier-of-mobile-money. 


\subsection{Background}

Consumer and business demands for financial services are constantly evolving. The need for real-time, frictionless services is evident, and the demands of service providers to internalize current needs and be proactive in researching and devising new business models that will meet both known and anticipated consumer needs are top of mind. Where business models offered by incumbents are not able to satisfy the needs of users of the financial system, these will be complemented or sometimes cannibalized by offerings from new entrants.

In an effort to remove the frictions relating to means of payment within the payment system, there has been an evolution relating to these mediums of payment. In past decades, 'electronic money' has become a buzzword. E-money is explained as stored value held in the accounts of users, agents and providers of mobile money services. Essentially, the total value of e-money should be mirrored in a bank account or bank accounts to ensure that users who stored the value in the account can safely recover 100 per cent of their value even if the service providers were to fail.

In recent times, mobile money schemes have emerged. In Africa, M-pesa has been the most prominent mobile money scheme. Mobile money schemes operate mainly in a closed-loop arrangement as their systems are not interlinked, and their instruments and infrastructure is not interoperable, which means the stores of value are not interchangeable. However, these instruments and schemes may be made interchangeable through complex clearing and settlement mechanisms to switch instruments and transfer stored value.

Recently, the concepts of crypto-assets/currency and CBDC have been introduced. These concepts are sometimes used interchangeably with virtual currencies, digital tokens and crypto tokens. The IFWG defines a crypto-asset as a digital representation of value that is not issued by a central bank, but is traded, transferred and stored electronically by natural and legal persons for the purpose of payment, investment and other forms of utility, and applies cryptography techniques in the underlying technology. This definition captures the various broad use cases and so the preferred term is crypto-assets rather than cryptocurrency. The term central bank digital currency, however, refers to a central bank liability, such as cash or deposits, issued in digital or electronic form, denominated in a sovereign currency and backed by the central bank's assets. ${ }^{2}$

2 Fabio Panetta, 21st Century Cash: Central Banking, Technological Innovation and Digital Currencies, Keynote address on the occasion of the SUERF-BAFFI CAREFIN Conference 'Do We Need a Central Bank Digital Currency? Economics, Technology 
Although there are no known fully implemented CBDC arrangements, several central banks are researching and experimenting with such arrangements within their jurisdictions, and perhaps even considering their use for removing frictions in cross-border payments.

A CBDC can be designed as an offering for either the wholesale or retail currency segment of the financial system. CBDC used in the retail sector will be similar to physical cash. In its design, it will offer users the same characteristics of physical cash: serving as a store of value, a medium of exchange and a unit of account. It will lend itself to use for frequent and relatively low- to medium-value transactions. In its wholesale form, CBDC may represent central bank money that is currently used to facilitate wholesale payments in national payment systems including real-time gross settlement systems. Ole Bjerg depicts CBDC as follows (see Figure 6.1).

Most central banks or monetary authorities working in this area are driven by certain public policy objectives. As stated earlier, CBDC is an attractive proposition where current instruments are not able to fulfil the desired need, such as enabling peer-to-peer electronic exchange of value. In some respects, there may be expectations that a CBDC may support the public policy objectives of enhancing financial inclusion and efficient disbursement of social benefits from the state.

\subsection{Review of key aspects relating to digital currency initiatives in Sub-Saharan Africa}

The South African IFWG has published a position paper on crypto-assets through its Crypto Assets Regulatory Working Group. ${ }^{3}$ Several countries in Africa have also published policy positions on crypto-assets/currencies.

On the CBDC front, most initiatives underway on the continent are mainly exploratory. This chapter will provide further details on some of them.

and Psychology', Milan, 7 June 2018, https://www.bancaditalia.it/media/notizia/fabiopanetta-speaks-on-21st-century-cash-central-banking-technological-innovation-anddigital-currencies.

3 Intergovernmental Fintech Working Group (IFWG), Position Paper on Crypto Assets, April 2020, https://www.ifwg.co.za/wp-content/uploads/IFWG_CAR_WG-Position_ Paper_on_Crypto_Assets.pdf. 


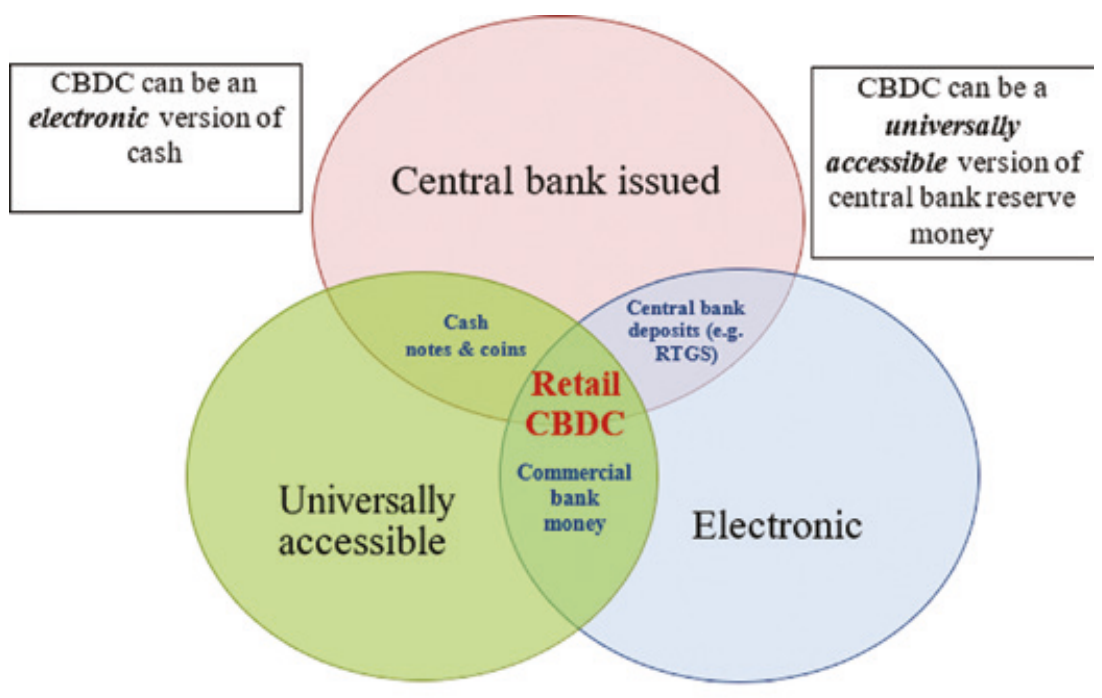

CBDC can be a central bank issued version

of commercial bank account money

Figure 6.1: Different forms of money.

Source: Author's elaboration on Ole Bjerg, 'Designing New Money. The Policy Trilemma of Central Bank Digital Currency', in CBS MPP Working Papers, June 2017, https://research.cbs.dk/en/ publications/designing-new-money-the-policy-trilemma-of-central-bank-digital-c.

\section{Objectives behind the initiatives}

The objectives of the development and issuance of policy and/or regulatory positions on crypto-assets/currencies by regulatory authorities is to outline and clarify their policy/regulatory positions on these developments. In this process, these authorities also recognize that their positions cannot be static and will need to be reviewed from time to time, as these business models and technological developments evolve. The objectives behind initiatives relating to CBDC are varied. A few are listed below:

1) to build capacity and gain a deeper understanding of the CBDC concept, as well as to analyse its benefits and potential risks;

2) to explore the feasibility of CBDC for possible issuance of electronic currency by central banks; 
3) to modernize the financial system, reduce cost of transactions and service delivery, increase efficiency in payments and improve financial inclusion;

4) to reduce the cost of circulating fiat currency, increase control of money supply and limit threats posed by the emergence of third-party firms in the area of currency issuance.

As evident from above, these objectives are interrelated and although some are focused on short- to medium-term exploration and learning, they may ultimately lead to the longer-term goals of modernizing and improving current arrangements and systems.

The specific objectives of CBDC programmes can include the identification of viable use cases and deployment models; legal and regulatory issues; monetary policy implications; financial stability implications; other policy-related matters; possible impact on the national payment system; and technical and security aspects.

\section{Key drivers of the initiatives}

For policy or regulatory positions adopted in relation to crypto-assets, the main goals are to highlight risks and possible benefits that could be derived from these developments and make financial system stakeholders and the public aware of the stance of the regulatory authorities.

Although the objectives and drivers for the CBDC initiatives may seem the same, it is important to at least outline the following three key drivers.

One key driver for exploring CBDC is to take a proactive stance in terms of evaluating the feasibility of its usage to address the possible decline in cash use. Although the actual decline of cash use has not been observed in many African countries, there are indications that this development is occurring in other parts of the world. It is therefore prudent to adopt a proactive stance and begin to explore the concept as this driver may be complemented by others and that may benefit the payment ecosystem.

Another driver emerges from the growth of unregulated private sector firms exploring offering crypto-assets as a means of payment. This compels central banks to look into what they can do to meet the demand, as their concern is related to the risks that such initiatives from private companies could create for the economy. The departure point for central banks would be that the adoption of the offerings by the private firms would be supported by the fact that there is an unfulfilled need in the market that current payment mechanisms do not meet. Therefore it is sensible to explore CBDCs that would meet the market's needs while also ensuring financial stability. 
The final key driver is the quest to adapt the payment system to maintain efficiency and resilience. As central banks have a mandate to ensure the development of the payment ecosystem, they have to observe changes in the financial system and develop appropriate responses. Developments in the digital era, where service offerings need to be frictionless and real-time, have prompted central banks to rethink their support arrangements for the broader financial system in line with their key mandates. This driver is therefore aligned to the mandate relating to payment systems.

Although this list of drivers is not exhaustive, it outlines drivers that are shared by stakeholders on the continent that are embarking on CBDC initiatives.

\section{Some key considerations for initiatives that are underway}

Considerations by central banks when determining policy positions relating to crypto-assets mainly relate to the risks that the offerings may present and the benefits that they may offer to the financial system.

When assessing the risks, the starting point is to evaluate these offerings in terms of whether they can serve as a unit of account, medium of exchange and store of value. Evaluating crypto-assets against each of these characteristics would reveal potential risks. The regulators would thus be in a good position to consider the risks and adopt appropriate policy positions that could be communicated to the public. Crypto-assets may also present benefits or remove frictions from the current payment system, and these will also be considered by authorities before approving their use as means of payment to discharge obligations.

A number of key considerations are involved in evaluating the possibility of a CBDC. These could sometimes sound like drivers, but they may be considered to strengthen or confirm a business case for exploring a CBDC. This section proposes some of these considerations.

Regulatory authorities and central banks may consider whether the offering of a CBDC would enhance efficiency and stability of the payment system by diversifying the system and reducing risk of concentration. The central bank may also consider whether the issuance of a CBDC may advance financial inclusion, and improve monetary policy implementation and transmission. A further consideration could be whether a CBDC would enhance competition and engender trust in the monetary system. These considerations could strengthen or weaken the business case.

Another set of considerations by regulatory authorities is the cost of issuing a CBDC compared to cash, whether a CBDC could reduce the cost of remittances, and whether a CBDC would be a secure and stable alternative for cross-border 
payments. The final consideration is the Financial Action Task Force implications and the practicalities in terms of specific proposals with reference to the issuance, distribution, transacting, and monitoring and maintenance of CBDC.

\subsection{Envisaged key characteristics of a successful crypto asset or CBDC}

For a crypto-asset or CBDC to be a success, it must have certain key characteristics. These would be what users of a payment system look for in payment instruments that they use for transactions. Although the list is not exhaustive, these are however the most important ones.

The crypto-asset or CBDC should be accepted as legal tender, build trust in its holders and parties that accept it as a means of payment, and be non-exclusive or ubiquitous. This will reassure users, merchants and service providers that they will always be able to exchange it for value with other users, merchants, service providers and participants in the conventional payment system.

The currency should not be cumbersome to use, be interoperable with other conventional payment systems and meet the best security standards. These are benchmarks met by payment instruments that are currently used widely. The instrument should further comply with regulations to fight money laundering and terrorism financing, be scalable and flexible, and ideally be usable both for online and offline transactions. When an instrument meets these requirements, its issuance when approved regulatory authorities, will be flexible for issuers within control measures that they are able to manage, and will further provide convenience to its users.

As stated earlier, these characteristics are prerequisites for a successful launch and sustainability of the payment instrument.

\subsection{Anticipated possible challenges}

When evaluating factors relating to crypto-assets, it is imperative that a balance be struck in weighing the risks and benefits. This is a challenging task because if the risks are easily identifiable, regulators may be confronted with negative perceptions that could blur mitigating factors. This may lead to the initiative being prematurely abandoned or to the adoption of a negative policy stance.

While the exploratory journey might be exciting, a cautious approach that recognizes possible challenges upfront is useful. Anticipating challenges and consequences prepares the authorities to navigate the complex process that may unfold and avoid unintended consequences. 
The first unintended consequence is that a retail CBDC that gives the public direct access to the central bank may lead to a loss of confidence in commercial banks and a shift of deposits to CBDC in times of financial crisis and systemic stress.

A second possible challenge that will need to be thought through from inception and affect design of the CBDC is interoperability with existing payment systems to enable seamless transactions while using the CBDC with other conventional payment instruments.

Third, it is crucial to anticipate public acceptance of CBDC, the response of other financial intermediaries, cyber security concerns and consumer data protection and privacy issues.

Lastly, the central bank needs to be prepared for the possibility that its balance sheet could grow considerably in case of high demand for CBDC.

These challenges may not be insurmountable, but must be considered during the planning of the CBDC exploration project.

\subsection{Approaches that have been adopted to crypto-currencies/ assets and CBDCs}

Approaches to crypto-currencies in the SADC have been reviewed, but these arrangements are less formalized nor inaccessible for the rest of the continent. Crypto currencies or assets are not recognized and regulated formally for use cases anywhere in Africa. Within the SADC region, many countries are closely observing developments in fintech in general and crypto-assets in particular, and the relevant use cases where they reserve the right to intervene where appropriate. Countries have issued policy stances stating that they will not regulate the issuance and use of crypto-currencies/assets, while also highlighting risks that these may pose and warning the public to be careful when using these instruments. Examples of these position or policy papers have been provided in the reference section, including the position on distributed ledger technologies and virtual currencies in Namibia, ${ }^{4}$ and the revised position on crypto-currencies. ${ }^{5}$

In South Africa, a joint warning statement was initially issued by the National Treasury, South African Reserve Bank, Financial Services Board, Financial

4 Bank of Namibia, Position on Distributed Ledger Technologies and Virtual Currencies in Namibia, September 2017, https://www.bon.com.na/getattachment/cd7ea698-3e854b79-b111-c97c7fae20fc/.aspx.

5 Bank of Namibia, Revised Positon on Cryptocurrencies, May 2018, https://www.bon. com.na/getattachment/2083bddd-a3c2-4932-b7e4-412e65b17e12/.aspx. 
Intelligence Centre and South African Revenue Services in 2014, which referred to crypto-currencies as virtual currencies. ${ }^{6}$ This was shortly followed by a position paper from the South African Reserve Bank on the same subject. ${ }^{7}$ The position in the two papers is however currently under review by a joint structure that has since been established to coordinate action on fintech developments in the country. A position paper on crypto-assets has been issued by the crypto-assets regulatory working group of the broader Intergovernmental Fintech Working Group. ${ }^{8}$ This position paper reviews the applicability of crypto-assets to various use cases and makes 30 specific recommendations for policy positions that need to be considered and possibly adopted.

It is generally recognized that the global landscape relating to CBDC is still fluid, and while some countries are conducting feasibility studies, others are already contemplating issuing CBDCs. An interesting paper by Stephen O'Neal shows that the situation regarding $\mathrm{CBDC}$ initiatives in Africa is somewhat confusing. ${ }^{9}$

According to this paper and other online publications, Senegal and Tunisia have adopted and issued CBDCs. These assertions have however been met with immediate denials by the authorities in the two countries.

In Tunisia news broke of the issuance of an E-dinar in November 2019, claiming the initiative would bring transparency, reduce cost of issuance and change how banks work. ${ }^{10}$ This was rejected by the Central Bank of Tunisia the same month in a sweeping statement that dismissed as 'unfounded' rumours that it had become the first monetary authority to issue a CBDC, while asserting instead that an unaffiliated 'proof of concept' project had been taken 'out of

6 South Africa National Treasury, User Alert: Monitoring of Virtual Currencies, 18 September 2014, http://www.treasury.gov.za/comm_media/press/2014/2014091801\% 20-\%20User\%20Alert\%20Virtual\%20currencies.pdf.

7 South African Reserve Bank, Position Paper on Virtual Currencies, 3 December 2014, https://www.resbank.co.za/RegulationAndSupervision/NationalPaymentSystem(NPS)/ Legal/Documents/Position\%20Paper/Virtual\%20Currencies\%20Position\%20Paper\%20 \%20Final_02of2014.pdf.

8 IFWG, Position Paper on Crypto Assets, cit.

9 Stephen O'Neal, 'State-Issued Digital Currencies: The Countries Which Adopted, Rejected or Researched the Concept', in Cointelegraph, 19 July 2018, https:// cointelegraph.com/news/state-issued-digital-currencies-the-countries-whichadopted-rejected-or-researched-the-concept.

10 Adrian Zmudzinski, 'Tunisia to Launch E-Dinar National Currency Using Blockchain, in Cointelegraph, 9 November 2019, https://cointelegraph.com/news/ tunisia-to-launch-e-dinar-national-currency-using-blockchain. 
context'. The bank did however admit that it was considering a CBDC and said that it is studying 'all existing alternatives'. It stressed that there are no immediate plans for an E-Dinar to go live and said; 'The bank is studying the opportunities and risks inherent in these new technologies, particularly in terms of cyber security and financial stability.' ${ }^{11}$

Reports also emerged claiming that Senegal would soon launch a digital currency known as eCFA. It was said to be an opportunity for fintech to help emerging markets leapfrog traditional banking systems and increase financial inclusion. These reports began in late 2016 and intensified in early 2017, only to be met by a similar rejection which has also been confirmed by the Central bank of the West African States, which said that it is observing developments related to CBDC.

Although these reports generated considerable excitement due to the enthusiasm of service providers, they were quickly denied. This is a new developing area that requires careful exploration, as demonstrated by approaches taken by other countries. Most importantly, central banks should guard against embracing solutions that are ahead of the problems they are supposed to solve. The O'Neal paper of 2018 identifies several countries that have either rejected or abandoned CBDC feasibility studies, and others that have chosen to continue experiments or research. ${ }^{12}$

Two African countries have taken a cautious approach. The Bank of Ghana, in its 91st Monetary Policy Committee Press Release on 25 November 2019, announced its intention to explore a CBDC pilot project in a sandbox environment. ${ }^{13}$ The bank has created a committee to explore the feasibility of a CBDC project and possible issuance of an electronic cedi (e-cedi). The work is still in its infancy, but its progress will be monitored with interest.

South Africa has also launched a CBDC feasibility study. The study will cover the lifecycle of a CBDC, comprising issuance, distribution, transacting, monitoring and maintenance, as outlined in Figure 6.2. At the initiation of the project, the central bank issued a request for information to prospective partners, from which it may select participants for the study.

11 Danny Nelson and Anna Baydakova, 'Denies Reports Claiming It Issued an E-Dinar', in Coindesk, 12 November 2019, https://www.coindesk.com/ tunisias-central-bank-denies-reports-claiming-it-issued-an-e-dinar.

12 Stephen O'Neal, 'State-Issued Digital Currencies..., cit.

13 Bank of Ghana, MPC Press Release, 25 November 2019, https://www.bog.gov.gh/ $? \mathrm{p}=19512$. 


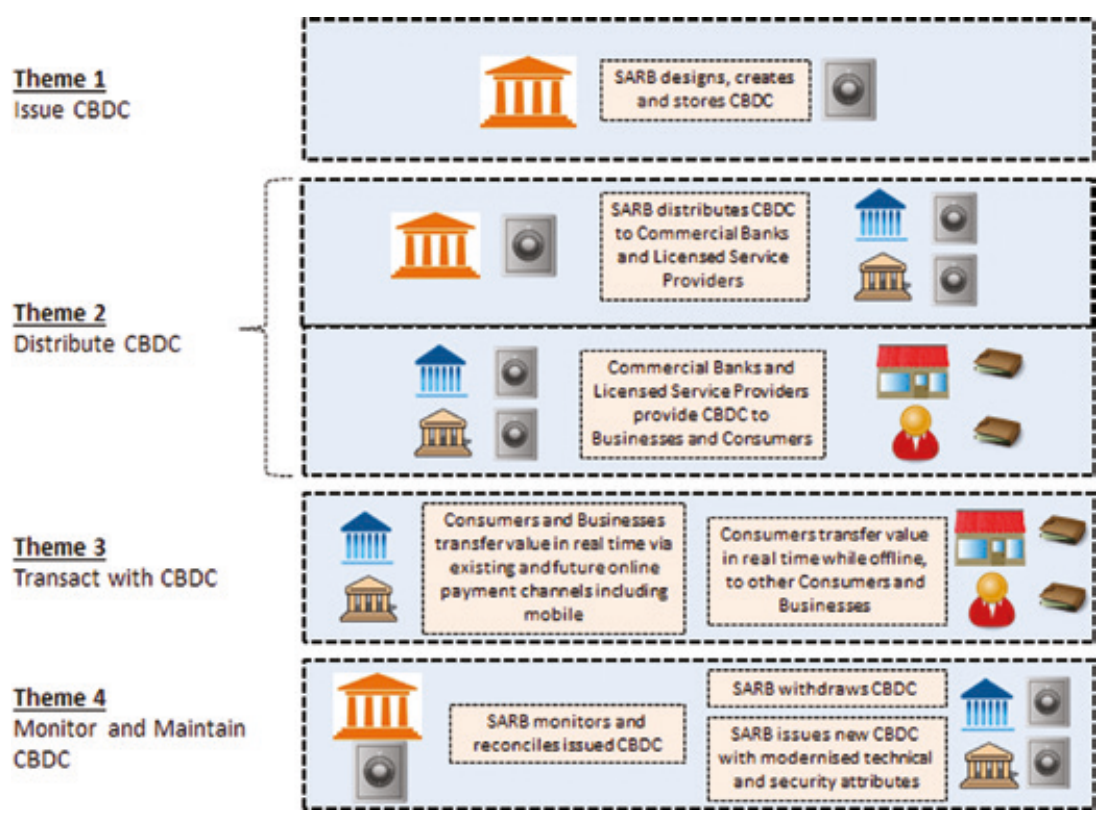

Figure 6.2: $C B D C$ lifecycle.

Source: South African Reserve Bank.

Some of the secondary objectives of the study include design considerations, policy impact, intended and unintended consequences, supportive legal and regulatory regime, process for ongoing monitoring, and incorporating learnings and perspectives from other central banks and related local and international forums. The project will explore different CBDC designs in parallel, test different use cases, and explore policy and regulatory implications and trade-offs. It is important to note that in this study, business processes are the key drivers and these are neutral in terms of solutions and technology infrastructure configurations. In summary, the project will cover the aspects shown in the Figure 6.3.

The South African CBDC feasibility study is still in its initial phase. Once the central bank has identified enough potential partners that will join the study, useful insights will be gathered and a final position will be reached. We expect the study to make a significant contribution to the body of knowledge on CBDC. 


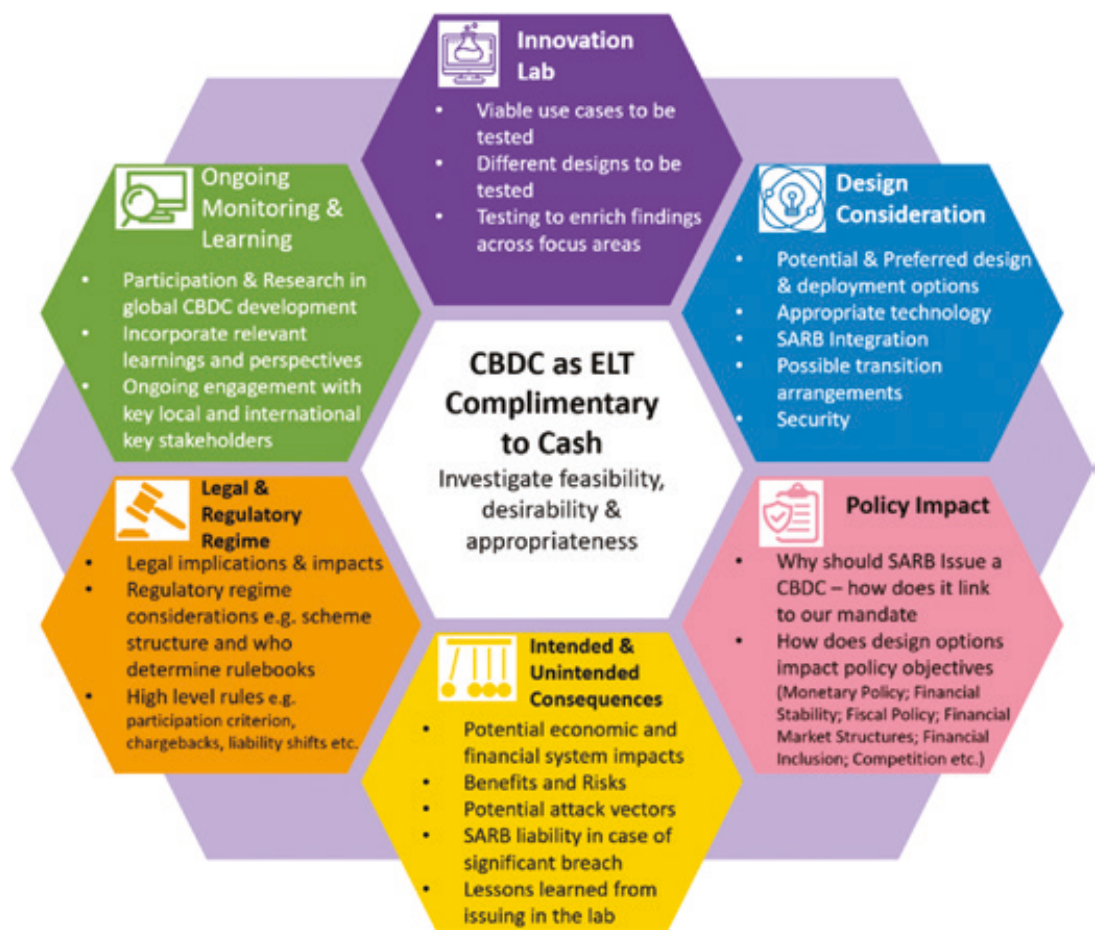

Figure 6.3: $\mathrm{CBDC}$ project.

Source: South African Reserve Bank.

\section{Conclusion}

This chapter discussed policy positions that have been adopted by a number of jurisdictions in Sub-Saharan Africa regarding crypto-currencies/assets and CBDCs. Most of these positions have been observed in the SADC region. Although some countries are reviewing or considering reviewing their policy positions, the authorities have generally warned the public about possible exposure in using crypto-assets. These positions are largely informed by the fact that the countries have currently chosen not to regulate crypto-currencies/assets while closely observing and studying their development. In South Africa, a position paper issued by the IFWG has made recommendations that, if adopted, 
could lead to some form of regulation of crypto-assets. ${ }^{14}$ The recommendations are under consideration.

Available information regarding CBDC initiatives in Africa is interesting but may also be misleading. The enthusiasm of some players although welcome, has caused confusion when followed by denials from central banks. This highlights the level of caution that central banks adopt in approaching the CBDCs, which contrasts with the enthusiasm of service providers.

The exploratory approach taken by two African central banks seem to be aligned to some of the feasibility and research approaches adopted by central banks in the other parts of the world. The ultimate success of a CBDC will depend on implementation that effectively addresses critical pain points in the payment ecosystem.

\section{References}

Michaela Allen and Barry Cooper, 'CBDC-The Next Frontier of Mobile Money?', in Central Bank Payments News, Vol. 3, No. 3 (March 2020), p. 22-25, https://cenfri.org/articles/cbdc-the-next-frontier-of-mobile-money

Bank of Ghana, MPC Press Release, 25 November 2019, https://www.bog.gov. $\mathrm{gh} / \mathrm{p}=19512$

Bank for International Settlements (BIS), Quarterly Review, March 2020, https://www.bis.org/publ/qtrpdf/r_qt2003.htm

Bank of Namibia, Position on Distributed Ledger Technologies and Virtual Currencies in Namibia, September 2017, https://www.bon.com.na/ getattachment/cd7ea698-3e85-4b79-b111-c97c7fae20fc/.aspx

Bank of Namibia, Revised Positon on Cryptocurrencies, May 2018, https://www. bon.com.na/getattachment/2083bddd-a3c2-4932-b7e4-412e65b17e12/.aspx

Ole Bjerg, 'Designing New Money. The Policy Trilemma of Central Bank Digital Currency', in CBS MPP Working Papers, June 2017, https://research.cbs.dk/en/publications/ designing-new-money-the-policy-trilemma-of-central-bank-digital-c

Lynsey Chutel, 'West Africa Now Has Its Own Digital Currency', in Quartz Africa, 27 December 2016, https://qz.com/africa/872876

Malick Ciss, 'West African Digital-Currency Project Shunned by Central Bank', in Bloomberg, 6 April 2017, https://www.bloomberg.com/news/articles/201704-06/west-african-digital-currency-project-shunned-by-central-bank

14 IFWG, Position Paper on Crypto Assets, cit. 
John Detrixhe, 'Central Banks Are Contemplating a World Without Cash', in Quartz, 1 March 2020, https://qz.com/1810727/ central-banks-are-researching-digital-currencies-to-replace-cash

Intergovernmental Fintech Working Group (IFWG), Position Paper on Crypto Assets, April 2020, https://www.ifwg.co.za/wp-content/uploads/IFWG_ CAR_WG-Position_Paper_on_Crypto_Assets.pdf

Ollen Machimbirike, 'Senegal, a Member of Western African Economic and Monetary Union ('WAEMU') Creates Digital Currency History', in Verdant Capital, 15 June 2017, https://verdant-cap.com/senegal-a-member-ofwestern-african-economic-and-monetary-union-waemu-creates-digitalcurrency-history

Avi Mizrahi, 'Senegal to Introduce Blockchain-based Currency to West Africa, eCFA', in Finance Magnates, 25 November 2016, https://www. financemagnates.com/? $\mathrm{p}=175985$

Danny Nelson and Anna Baydakova, 'Denies Reports Claiming It Issued an E-Dinar', in Coindesk, 12 November 2019, https://www.coindesk.com/ tunisias-central-bank-denies-reports-claiming-it-issued-an-e-dinar

Stephen O'Neal, 'State-Issued Digital Currencies: The Countries Which Adopted, Rejected or Researched the Concept', in Cointelegraph, 19 July 2018, https://cointelegraph.com/news/state-issued-digitalcurrencies-the-countries-which-adopted-rejected-or-researched-theconcept

Fabio Panetta, 21st Century Cash: Central Banking, Technological Innovation and Digital Currencies, Keynote address on the occasion of the SUERFBAFFI CAREFIN Conference 'Do We Need a Central Bank Digital Currency? Economics, Technology and Psychology’, Milan, 7 June 2018, https://www.bancaditalia.it/media/notizia/fabio-panetta-speaks-on-21stcentury-cash-central-banking-technological-innovation-and-digitalcurrencies

South Africa National Treasury, User Alert: Monitoring of Virtual Currencies, 18 September 2014, http://www.treasury.gov.za/comm_media/press/2014/ 2014091801\%20-\%20User\%20Alert\%20Virtual\%20currencies.pdf

South African Reserve Bank, Position Paper on Virtual Currencies, 3 December 2014, https://www.resbank.co.za/RegulationAndSupervision/ NationalPaymentSystem(NPS)/Legal/Documents/Position\%20Paper/ Virtual\%20Currencies\%20Position\%20Paper\%20\%20Final_02of2014.pdf

Adrian Zmudzinski, 'Tunisia to Launch E-Dinar National Currency Using Blockchain', in Cointelegraph, 9 November 2019, https://cointelegraph.com/ news/tunisia-to-launch-e-dinar-national-currency-using-blockchain 
Jan Knoerich

\section{Chapter 7: China's New Digital Currency: Implications for Renminbi Internationalization and the US Dollar}

Central bank digital currencies (CBDCs) are predicted to transform the way ordinary payments will be made in the future, both within countries and across national borders. Several countries have begun the process of developing them, and China is widely recognized as running the world's most advanced programme in this area. As early as 2014, the People's Bank of China (PBoC) had set up an expert research team to explore the technical and regulatory requirements for a CBDC, and in 2017 it established its own Digital Currency Research Institute. ${ }^{1}$ The most significant development occurred in April 2020, when China became the first country to launch a pilot programme to test its digital currency. Given the head start China has had over other countries in developing a CBDC, the suitability of a digital currency to what is already a largely cashless society and the determination of the Chinese government to forge ahead with this project, it is reasonable to expect that the first CBDC in the world will be launched by China.

For China, being a first mover in the development of such an important new technology can be of particular geo-strategic significance. Not only would an early introduction of a CBDC place China in an advantageous position for an upcoming battle against other digital currencies and Facebook's Libra, it would also play a role in China's ongoing efforts to internationalize its currency, the renminbi (RMB), aimed at increasing its attractiveness as a global trade, investment and reserve currency. As the second largest economy that is on track to become the world's largest, and as the world's largest exporter, China holds aspirations to unseat the United States as the leading global political and economic power. A strong RMB would enhance China's ability to project its power internationally and challenge the US dollar's preeminent global role. Could a CBDC be a

1 'Digital Currency Research Institute of the People's Bank of China', in China Banking News, 2 October 2018, https://www.chinabankingnews.com/?p=12050; Chuan Tian, 'China's Central Bank Opens New Digital Currency Research Institute', in CoinDesk, 30 June 2017, https://www.coindesk.com/chinas-centralbank-opens-new-digital-currency-research-institute. 
game-changer, effectively enabling China to elevate the RMB to a more dominant international position?

This chapter examines China's plans for a CBDC in detail to assess its potential significance for China and the world. It begins by analysing the expected properties of the proposed digital currency and the implications it could have for payments in China and beyond. Next, it will discuss progress made with the internationalization of the RMB and the potential contribution China's digital currency can make in this process of currency internationalization. Finally, the chapter will consider the extent to which China's CBDC could enable the RMB to challenge the US dollar and what the implications are for global currency politics. $^{2}$

\subsection{China's new central bank digital currency}

China's CBDC project runs under the label Digital Currency/Electronic Payments (DCEP). While many details are still subject to final confirmation and may change according to insights obtained from the pilot phase, and much is being kept secret, the current state of knowledge suggests that DCEP will have the following properties and functions.

\section{Properties and functions of DCEP}

As the terminology indicates, DCEP's main purpose is to create an electronic mode for payments that is sanctioned as legal tender by the Chinese government. ${ }^{3}$ It will be fully backed by the central bank at a 1:1 ratio to RMB fiat currency and effectively constitute a central bank liability. DCEP aims to substitute cash (M0 money supply) without altering the money in circulation and will be non-interest bearing and subject to transaction limits and payments regulations. ${ }^{4}$ It is expected to be token-based and is not envisioned to serve as a store of value.

DCEP will operate a two-tiered system. The first tier will involve the $\mathrm{PBoC}$ issuing digital currency to intermediaries, which will be China's four major stateowned commercial banks (Bank of China, Industrial and Commercial Bank of China, China Construction Bank and Agricultural Bank of China), and payment

2 The author would like to thank four experts for the thoughts and insights they provided on the subject.

3 Michael Gu, 'China's National Digital Currency DCEP/CBDC Overview', in Boxmining, 13 October 2020, https://boxmining.com/dcep/\#What_is_DCEP.

4 Katie-Ann Wilson, 'China's Next World-First', in OMFIF Articles, 3 July 2020, https:// www.omfif.org/2020/07/chinas-next-world-first. 
services such as Alibaba's Alipay, Tencent's WeChat Pay and China UnionPay. Telecommunications companies China Telecom, China Mobile, China Unicom and, potentially, Huawei, will also be involved. As the second tier, the intermediaries will distribute digital currency to individuals and companies in the retail sector. While avenues for distribution might vary, many expect the digital currency will be held in digital wallets, with electronic payments to be made through transfers between these wallets. Using DCEP will not be tied to the possession of a bank account, though bank deposits can be converted into digital currency. ${ }^{5}$ It is therefore not intended to substitute demand or savings deposits (M1 or M2), although this could be attempted at a later stage of DCEP's development. ${ }^{6}$ The technology is expected to have functionality for near-field communication (NFC), such as Bluetooth, to enable payments even when the devices used at the time of transaction are offline or in areas with low internet coverage. Such offline payments could be accomplished by touching two smartphones.

The technological properties of DCEP have yet to be finalized, and the current approach accommodates various technological solutions to allow for future adjustments in view of technological advances. Technological solutions will have to meet specified requirements in the first tier (such as high scalability, high concurrency, good customer experience and strict technical specifications), while different types of ledger systems (distributed, centralized, blockchain) and payment methods (mobile, internet, offline) could be accommodated in the second tier, depending on the preferences of the intermediaries. ${ }^{8}$ It is quite possible that distributed ledger technology (DLT) will play an important role and is likely to involve 'permissioned' DLT or blockchain networks, ${ }^{9}$ in which access to the blockchain and ledger updating will be limited to a select group, enabling the

5 Michael Gu, 'China's National Digital Currency DCEP/CBDC Overview', cit.; 'China's Digital Currency to Start Pilots', in Ledger Insights, 9 December 2019, https://www. ledgerinsights.com/? $\mathrm{p}=10208$.

6 Cissy Zhou, 'China's Digital Currency Edges Closer with Large-Scale Test by Four State-Owned Banks', in South China Morning Post, 6 August 2020, https:// www.scmp.com/economy/china-economy/article/3096296/chinas-digitalcurrency-edges-closer-large-scale-test-four.

7 Michael Gu, 'China's National Digital Currency DCEP/CBDC Overview', cit.

8 Sundeep Gantori et al., Information Technology. Understanding China's Digital Currency and Blockchain Initiatives, UBS, 23 April 2020, https://docplayer.net/191072050Information-technology.html.

9 Yuan Yang and Hudson Lockett, 'What is China's Digital Currency Plan?', in Financial Times, 25 November 2019, https://www.ft.com/content/e3f9c3c2-0aaf11ea-bb52-34c8d9dc6d84. 
central bank to maintain control over the money supply. ${ }^{10}$ China's leaders have been vigorously pushing research into blockchain technologies over the past few years and its State Information Center (SIC) has recently established the Blockchain Service Network (BSN) to expand and better integrate blockchain infrastructure both domestically and internationally. ${ }^{11}$ However, the technologies used for DCEP must have the capacity to process a vast number of smallscale transactions, potentially as many as 300,000 transactions per second, ${ }^{12}$ which may be difficult to achieve with existing blockchain technologies (Alipay has reported being able to process up to 256,000 payment transactions per second).$^{13}$ The PBoC has filed more than 80 patents related to DCEP, ${ }^{14}$ and the large Chinese internet giants (e.g. Alibaba and Tencent) are working with the Chinese government on the development of DCEP. ${ }^{15}$

DCEP will probably operate under the principle of 'controllable anonymity'. This means that, while all transactions are recorded, only the PBoC will have the capability to track overall payment behaviour. ${ }^{16}$ This could erode privacy,

10 PwC, The Rise of Central Bank Digital Currencies (CBDCs). What You Need to Know, November 2019, https://www.pwc.com/gx/en/financial-services/pdf/the-rise-ofcentral-bank-digital-currencies.pdf.

11 Sundeep Gantori et al., Information Technology ..., cit.; David Pan, 'China's Blockchain Infrastructure to Extend Global Reach', in CoinDesk, 21 July 2020, https://www. coindesk.com/chinas-blockchain-infrastructure-to-extend-global-reach-with-sixpublic-chains.

12 Sundeep Gantori et al., Information Technology..., cit.

13 See Alipay Twitter post of 11 November 2017: https://twitter.com/alipay/status/ 929123909970153472.

14 Hannah Murphy and Yuan Yang, 'Patents Reveal Extent of China's Digital Currency Plans', in Financial Times, 12 February 2020, https://www.ft.com/content/ f10e94cc-4d74-11ea-95a0-43d18ec715f5.

15 Henny Sender, 'China's New Digital Currency Takes Aim at Alibaba and Tencent', in Financial Times, 4 August 2020, https://www.ft.com/content/fec06de9-ac43-4ab881f3-577638bd3c16; Jonas Gross and Alexander Bechtel, 'China’s Digital Currency Project: What Is DC/EP All About?', in Medium, 4 June 2020, https://link.medium. com/IbOTCm63Mab.

16 Ye Shi and Shucheng Zhou, Central Bank Digital Currencies: Towards a Chinese Approach. Design Choices of Digital Currency Electronic Payment, Master Thesis, Jönköping University International Business School, May 2020, http://urn.kb.se/ resolve?urn=urn:nbn:se:hj:diva-48662; Raymond Zhong, 'China's Cryptocurrency Plan Has A Powerful Partner: Big Brother', in The New York Times, 18 October 2019, https://nyti.ms/32sFMnw. 
and the PBoC will need to offer reassurances that it will use such powers only in circumstances where illicit financial activities are suspected.

The overall operational structure of DCEP is expected to follow a ' $1,2,3$ framework, ${ }^{17}$ referring to the digital currency as the one token and the PBoC's central ledger and the data centres of the intermediaries as two separated but connected addresses. There are also three centres - an Identification Centre to identify new users, a Record Centre to record all transactions, issuances and transfers, and an Analytics Centre to conduct big data analysis of customer behaviours, macroeconomic implications and illicit activities. ${ }^{18}$

The PBoC has announced that the back-end architecture development for DCEP, including design, standards and functionality, has been completed. DCEP is now being tested and corresponding laws are being drafted. ${ }^{19}$ Pilot trials were launched in April 2020 in Shenzhen, Suzhou (Xiangcheng District), Chengdu and Xiong'an near Beijing, in which government and bank employees and public servants have received specified funds such as parts of their transport subsidies in digital currency, and selected catering and retail companies have been involved in testing the digital currency. ${ }^{20}$ As part of the trials, state-owned commercial banks have been developing and testing consumer-facing DCEP digital wallets. As the pilot phase continues, new types of trials are being launched, covering various kinds of economic activities. For example, one trial involved giving 50 thousand Shenzhen residents digital coupons worth RMB 200 yuan each, to be spent between 12 and 18 October 2020 in designated shops. ${ }^{21}$ How long trials

17 Ryan Todd and Mike Rogers, A Global Look at Central Bank Digital Currencies. From Iteration to Implementation, The Block Research for KPMG and Blockset, August 2020, https://www.tbstat.com/wp/uploads/2020/08/KPMG-CBDC-Report.FINAL_.v.1.02. pdf.

18 Shuyao Kong, 'DCEP: An Inside Look at China's Digital Currency', in Decrypt, 28 June 2020, https://decrypt.co/33866; Ye Shi and Shucheng Zhou, Central Bank Digital Currencies: Towards a Chinese Approach, cit.

19 Mohammad Musharraf, 'Digital Yuan's Backend Development Complete, Says Chinese Official', in CoinTelegraph, 22 June 2020, https://cointelegraph.com/news/digital-yuansbackend-development-complete-says-chinese-official; Michael Gu, 'China's National Digital Currency DCEP/CBDC Overview', cit.

20 Helen Davidson, 'China Starts Major Trial of State-run Digital Currency', in The Guardian, 28 April 2020, https://gu.com/p/dmgg3; Sundeep Gantori et al., Information Technology..., cit.

$21 \mathrm{Hu}$ Yue and Luo Meihan, 'China Gives Away \$1.5 Million to Test Digital Currency', in Caixin Global, 9 October 2020, https://www.caixinglobal.com/2020-10-12/chinagives-away-15-million-to-test-digital-currency-101613663.html. 
will continue until DCEP is ready for a full launch is unclear and no official timetable has been given. The 2022 Beijing Winter Olympics have been suggested as a venue to test DCEP on foreign visitors, ${ }^{22}$ an indication that some time might still pass before the digital currency is ready for a full launch.

\section{Implications of a digital currency for China}

There are many reasons why DCEP could be beneficial to China, especially when launched relatively early. These benefits could explain Beijing's ambitions to vigorously push this initiative.

Generally, DCEP could lower the cost of issuing paper money and coins, reduce the friction of bank transfers and make financial transactions more efficient. ${ }^{23}$ In pushing DCEP, the government is reacting to the rapidly declining role of cash in Chinese society, where people are exceptionally adept in using their smartphones for all kinds of transactions, large or small. ${ }^{24}$ More than 80 per cent of smartphone owners use them for payments in China, which has the largest mobile payment adoption rate globally. ${ }^{25}$ Private payment services such as Alipay and WeChat Pay have become powerful and systemically relevant in China and clawing back some of this power into the hands of the state-owned commercial banks and the $\mathrm{PBoC}$ could strengthen financial supervision and financial stability. ${ }^{26}$ Wresting back some of this power will also reduce the influence these companies will have on determining the future evolution of digital payments.

DCEP can further advance financial digitization, innovation and productivity. ${ }^{27}$ Its functionality with NFC technology is expected to promote financial inclusion by making electronic payments services available to non-banked people in smaller cities and rural areas. Digital money is also more hygienic than cash, an aspect that has gained great relevance with the COVID-19 pandemic. ${ }^{28}$

22 Ryan Todd and Mike Rogers, A Global Look at Central Bank Digital Currencies..., cit.

$23 \mathrm{PwC}$, The Rise of Central Bank Digital Currencies (CBDCs)..., cit.; Sundeep Gantori et al., Information Technology ..., cit.

24 Henry M. Paulson, 'The Future of the Dollar', in Foreign Affairs, 19 May 2020, https:// www.foreignaffairs.com/node/1126037.

25 Sundeep Gantori et al., Information Technology ..., cit.

26 Henny Sender, 'China’s New Digital Currency Takes Aim at Alibaba and Tencent', cit.; Jonas Gross and Alexander Bechtel, 'China's Digital Currency Project: What Is DC/ EP All About?', cit.

27 Sundeep Gantori et al., Information Technology ..., cit.

28 Jonas Gross and Alexander Bechtel, 'China’s Digital Currency Project: What Is DC/EP All About?', cit. 
The traceability and potential programmability of a digital currency will enhance central bank supervision and the government's control over money flows and financial activities. These two features of DCEP could help combat illicit financial activities, such as corruption, fraud, money laundering, terrorist financing and tax evasion, ${ }^{29}$ though they may potentially intensify government monitoring of society. ${ }^{30}$ The data obtainable from traceable digital currency could facilitate the monitoring of money flows, offering an improved means for analysis of economic activity and financial stability. Traceability and potential programmability of digital money would provide a new instrument to better control the money supply, make monetary policy smarter and enhance macroprudential regulation. ${ }^{31}$ Cross-border transactions might also be better controlled..$^{32}$ All this is unlikely to change the money supply itself and there should be no implications for inflation. ${ }^{33}$

At an international level, DCEP could facilitate broader global circulation of the RMB and potentially weaken the US-dominated cross-border payment system. ${ }^{34}$ An early launch of DCEP will also defy Facebook's Libra, which the Chinese government considers a threat, and will position China ahead of others should the rise of digital currencies trigger a fundamental reorientation of the global financial architecture. ${ }^{35}$ These considerations will be discussed in greater detail in the next sections.

29 PwC, The Rise of Central Bank Digital Currencies (CBDCs)..., cit.; Sundeep Gantori et al., Information Technology ..., cit.; Ye Shi and Shucheng Zhou, Central Bank Digital Currencies: Towards a Chinese Approach, cit.

30 Roger Huang, 'China Will Use Its Digital Currency to Compete with the USD', in Forbes, 25 May 2020, https://www.forbes.com/sites/rogerhuang/2020/05/25/ china-will-use-its-digital-currency-to-compete-with-the-usd.

31 Yao Qian, 'Central Bank Digital Currency: Optimization of the Currency System and Its Issuance Design', in China Economic Journal, Vol. 12, No. 1 (2019), p. 1-15; Yao Qian, 'A Systematic Framework to Understand Central Bank Digital Currency', in Science China Information Sciences, Vol. 61, Article 033101 (2018).

32 Jonas Gross and Alexander Bechtel, 'China’s Digital Currency Project: What Is DC/EP All About?', cit.

33 Sundeep Gantori et al., Information Technology ..., cit.; PwC, The Rise of Central Bank Digital Currencies (CBDCs)..., cit.

34 Michael Gu, 'China's National Digital Currency DCEP/CBDC Overview', cit.

35 Raymond Zhong, 'China's Cryptocurrency Plan Has A Powerful Partner: Big Brother', cit. 
Despite the potential benefits of DCEP, its introduction will not be without risks. A key concern is that DCEP might erode the role of commercial banks as financial intermediaries and could result in disintermediation. ${ }^{36}$ The two-tiered setup and non-interest-bearing nature of the DCEP plan is meant to reduce the likelihood of this occurring. ${ }^{37}$ DCEP will be particularly disruptive if not destructive to the business of card companies, and payment services offered by Alipay and WeChat Pay will have to adapt as well. ${ }^{38}$ The current Alipay and WeChat Pay systems are not compatible, and DCEP offers an opportunity to decompartmentalize the digital payments system. Despite these systemic shifts, the commercial banks and digital payment service providers should also be able to identify numerous new business opportunities from the introduction of DCEP. ${ }^{39}$ Cyber security is another area of concern, especially threat of hacking, ${ }^{40}$ and some may also be concerned about the lack of guaranteed privacy and anonymity of DCEP, which could be abused by authorities e.g. to intensify control over the behaviour of citizens. ${ }^{41}$

Finally, other implications not mentioned here can also be expected, and rolling out such a technologically complex project in an area so important for the functioning of the economy and financial system may result in unforeseen and possibly serious consequences. ${ }^{42}$ These problems might be particularly acute for the first-mover CBDC. To avoid this, the maintenance of high technical standards and requirements will be important. ${ }^{43} \mathrm{~A}$ pragmatic, stepwise introduction of DCEP could also help forestall unforeseen problems. The fact that China is testing DCEP through pilot projects indicates a cautious approach, in line with the policy experimentation China has traditionally employed to advance its economic reforms.

36 PwC, The Rise of Central Bank Digital Currencies (CBDCs)..., cit.

37 Katie-Ann Wilson, 'China's Next World-First', cit.

38 Richard Turrin, 'China’s CBDC', in PCN Magazine, Vol. 6, No. 2 (July 2020), p. 6-9, https://www.teampcn.com/magazine/magazine/china-s-cbdc.

39 Sundeep Gantori et al., Information Technology..., cit.

40 PwC, The Rise of Central Bank Digital Currencies (CBDCs)..., cit.; Sundeep Gantori et al., Information Technology..., cit.

41 Raymond Zhong, 'China's Cryptocurrency Plan Has A Powerful Partner: Big Brother', cit.; Jonas Gross and Alexander Bechtel, 'China’s Digital Currency Project: What Is DC/ EP All About?', cit.

42 Committee on Payments and Market Infrastructures, 'Central Bank Digital Currencies', in CPMI Papers, No. 174 (March 2018), https://www.bis.org/cpmi/publ/d174.htm.

43 Sundeep Gantori et al., Information Technology..., cit. 


\subsection{China's renminbi internationalization}

Since 2009, in the wake of the financial crisis, China began to actively promote the internationalization of the RMB. There was frustration that US dollar hegemony enabled the country at the source of the crisis - the United States - to use monetary policy to shield itself better from the economic fallout than peripheral countries like China, which incurred considerable damage. ${ }^{44}$

\section{Steps taken to internationalize the renminbi}

From the financial crisis onwards, China engaged in a series of activities to advance the internationalization of the RMB. The first step was to create offshore RMB bond markets, starting with so-called dim sum bonds in Hong Kong in 2007 and then expanding the issuance of RMB-denominated bonds to other geographical areas. ${ }^{45}$ This made possible the purchase of RMB-denominated bonds outside China, where they were subject to fewer restrictions. ${ }^{46}$ At this time China also launched the offshore renminbi $(\mathrm{CNH})$ next to its onshore counterpart (CNY). A more direct effort at advancing the internationalization of the RMB soon followed with China's conclusion of a large number of bilateral currency swap arrangements with other countries, providing greater cross-border liquidity and other benefits. By 2020, more than 30 swap lines were established, resulting in China by far exceeding the number of swap lines of other countries - the United States in second place had less than half that number. ${ }^{47}$

An important focus area of RMB internationalization was the promotion of international trade settlement, advanced primarily in the early- to mid-2010s.

44 Di Dongsheng, 'The Economics and Politics of China's Currency Internationalization', in Global Asia, Vol. 15, No. 2 (June 2020), p. 58-64, https://www.globalasia.org/ v15no2/cover/the-economics-and-politics-of-chinas-currency-internationalization di-dongsheng; Daniel McDowell, 'The (Ineffective) Financial Statecraft of China's Bilateral Swap Agreements', in Development and Change, Vol. 50, No. 1 (January 2019), p. 122-143.

45 Hung-Gay Fung et al., 'The Offshore Renminbi Bonds: The Dim Sum and Formosa Bonds', in The Chinese Economy, Vol. 49, No. 4 (2016), p. 287-299.

46 Center for Strategic and International Studies (CSIS), 'Will China's Push to Internationalize the Renminbi Succeed?', in ChinaPower, 18 June 2020, https://wp.me/ p8Side-1AP.

47 Di Dongsheng, 'The Economics and Politics of China's Currency Internationalization', cit.; Daniel McDowell, 'The (Ineffective) Financial Statecraft of China's Bilateral Swap Agreements', cit. 
This involved the establishment of a network of offshore RMB clearing hubs in financial centres across the globe to facilitate the cross-border settlement in RMB. Each hub had one of the state-owned commercial banks as the designated clearing bank. ${ }^{48}$ This massively expanded cross-border trade settlement in RMB, though much of it remained concentrated in Hong Kong. Clearing of inward and outward foreign direct investment in RMB was also permitted..$^{49}$ In 2015, China launched its Cross-border Interbank Payments System (CIPS) to facilitate international clearing and settlement in RMB in parallel to the SWIFT global standard.

China's ambition to internationalize the RMB has been supported by various other domestic and cross-border initiatives and reforms. Participation by foreign institutional investors in China's bond and stock markets has been gradually expanded, and stock-connect programmes were introduced with Hong Kong and London, followed by a bond-connect programme with Hong Kong in 2017. Domestic interest rates have become more market-determined and the RMB exchange rate has been allowed to float more widely in recent years. ${ }^{50}$ In 2015, the currency's managed float regime was reset to follow a basket of currencies, whereas previously it had only followed the US dollar. These and other initiatives can be seen as slow steps towards a tentative relaxation of capital account restrictions. The Belt and Road Initiative (BRI), with financing support from China's recently established international development banks - in particular the Asian Infrastructure Investment Bank (AIIB), Silk Road Fund and the New Development Bank - have also been identified as vehicles to promote RMB internationalization. ${ }^{51}$

The growing international role of the RMB was recognized in 2016 by the currency's inclusion into the Special Drawing Rights (SDR) basket, which is an international reserve asset created by the International Monetary Fund (IMF). Primarily of symbolic importance, its inclusion elevated the RMB to a status

48 Ramon Pacheco Pardo, Jan Knoerich and Yuanfang Li, 'The Role of London and Frankfurt in Supporting the Internationalisation of the Chinese Renminbi', in New Political Economy, Vol. 24, No. 4 (2019), p. 530-545.

49 CSIS, 'Will China's Push to Internationalize the Renminbi Succeed?', cit.

50 Di Dongsheng, 'The Economics and Politics of China's Currency Internationalization', cit.

51 Ibid.; SWIFT, Beyond Borders: China Opens Up to the World, RMB Tracker special edition, June 2019, https://www.swift.com/swift-resource/227391/download; Jan Knoerich and FranciscoUrdinez, 'Contesting Contested Multilateralism: Why the West Joined the Rest in Founding the Asian Infrastructure Investment Bank', in The Chinese Journal of International Politics, Vol. 12, No. 3 (Autumn 2019), p. 333-370. 
alongside the US dollar, euro, yen and pound despite its still limited importance as an international investment and reserve currency.

\section{Limitations of renminbi internationalization}

All these initiatives at promoting the internationalization of the RMB had the effect of expanding global use of the currency. But after an initial push during the first half of the 2010s, the crash on China's stock markets in 2015 compelled the government to devalue the RMB. Capital controls were tightened to prevent even greater currency depreciation and capital flight. This reduced international confidence in the RMB and had the effect of slowing down its internationalization, in some areas reversing progress already made. ${ }^{52}$

Table 1 illustrates how, despite China being the world's second largest economy and largest trading nation, the share of the RMB in three important measures of currency internationalization - global payments, activity in the foreign exchange market and foreign exchange reserves - remains well below 5 per cent, ranking behind the other major reserve currencies. Having started at close to zero just a decade earlier, the current level can nevertheless be considered impressive, yet China still has a long way to go until its currency becomes truly international. The US dollar and the euro clearly dominate, and the fact that these two currencies are already deeply enmeshed in the international financial architecture will make it hard to unseat them.

These still comparatively modest figures and the slowing down of RMB internationalization in recent years have exposed the limitations of China's reliance on payment infrastructure programmes and conditional access schemes, aimed at promoting internationalization while maintaining full control and potential reversibility of the process. China's capital account remains among the least open in the world and its financial markets among the most restricted to foreign participants. These self-imposed limitations are keeping the RMB below its true potential. $^{53}$

Achieving further meaningful currency internationalization will require greater trade-offs. To truly internationalize, the RMB needs to circulate globally at a higher rate, but China's persistent current account surplus is hindering an increase in global circulation of the currency. Another option to

52 CSIS, 'Will China's Push to Internationalize the Renminbi Succeed?', cit.

53 Maximilian Kärnfelt, 'China's Currency Push. The Chinese Yuan Expands Its Footprint in Europe', in China Monitor, 9 January 2020, https://merics.org/en/report/ chinas-currency-push. 
Table 7.1: Global utilization of the RMB is still comparatively limited.

\begin{tabular}{llll}
\hline Currency & $\begin{array}{l}\text { Share of global } \\
\text { payments } \\
\text { June 2020, \% (Rank) }\end{array}$ & $\begin{array}{l}\text { Share of foreign } \\
\text { exchange market } \\
\text { turnover } \\
\text { April 2019, \% (Rank) }\end{array}$ & $\begin{array}{l}\text { Share of allocated } \\
\text { foreign exchange } \\
\text { reserves } \\
\mathbf{1 Q 2 0 2 0} \text { \% (Rank) }\end{array}$ \\
\hline USD & $40.33(1)$ & $88.3(1)$ & $61.99(1)$ \\
EUR & $34.10(2)$ & $32.3(2)$ & $20.05(2)$ \\
GBP & $7.08(3)$ & $12.8(4)$ & $4.43(4)$ \\
JPY & $3.74(4)$ & $16.8(3)$ & $5.70(3)$ \\
CNY & $\mathbf{1 . 7 6 ( 5 )}$ & $\mathbf{4 . 3 ( 8 )}$ & $\mathbf{2 . 0 2 ( 5 )}$ \\
\hline
\end{tabular}

Source: $\left({ }^{*}\right)$ SWIFT, (SWIFT, RMB Tracker, July 2020, https://www.swift.com/swift-resource/ $249256 /$ download.) (**) BIS, (The maximum possible is 200 per cent, as two parties are involved in any one transaction. Bank for International Settlements (BIS), Foreign Exchange Turnover in April 2019, 16 September 2019, https://www.bis.org/statistics/rpfx19_fx.htm.) ( ${ }^{* * *)}$ IMF.(IMF Data: Table 1, World Currency Composition of Official Foreign Exchange Reserves, https://data. imf.org/regular.aspx?key=41175.)

increase global circulation is by expanding capital outflows, ${ }^{54}$ but this requires greater convertibility on the capital account, removal of restrictions on inward and outward capital flows and continuous opening up of China's financial markets to foreign participation. Removing capital flow restrictions would force China to accept reduced control over capital flows and greater swings in the exchange rate, potentially having to relinquish control over it entirely. But the government is unlikely to accept such loss of control any time soon, out of fear such moves could destabilize China's financial system and facilitate capital flight.

The financial system in China remains weak and underdeveloped, facing many problems including lack of regulation, inefficiency in allocating credit to the most productive investments, excessive speculation and risk-taking, corruption, financial scandals, moral hazard, and soft budget constraints..$^{55}$ A major concern are high levels of debt, held primarily by state-owned enterprises, local governments and individual households, and a surging number of non-performing loans. Some estimate China's debt to exceed 300 per cent of GDP, though the true extent of the problem remains unknown.

54 George Magnus, Red Flags. Why Xi's China is in Jeopardy, New Haven, Yale University Press, 2018, p. 101-102.

55 Ibid. 
A considerable amount of financial leverage has emerged in China's obscure shadow-banking sector, which has tolerated opaque financial practices such as the issuance of off-balance sheet loans, peer-to-peer lending and high-risk wealth management products.

Since 2017, the Chinese government has intensified efforts to address some of these problems. It has issued new rules, regulations and guidelines, restructured regulatory institutions, re-organized financial governance, clamped down on illicit behaviour and dubious financial practices, and reigned in shadow-banking activities including peer-to-peer lending and the sale of high-risk wealth management products. ${ }^{56}$ But more needs to be done before China can confidently open its financial markets without having to fear major capital flight or other forms of financial instability. Unfortunately, it is likely that the coronavirus pandemic will reduce Beijing's appetite for financial reforms. On the contrary, China appears prepared to allow debt to accumulate further to cushion the economic fallout from the crisis.

For broader international adoption of the RMB, Beijing will need to build international confidence in the regulatory, governance and institutional structures underpinning the currency. This will require greater reliance on market mechanisms and reduction of government intervention, which can be erratic, as the sudden devaluation of the exchange rate after the stock market crisis has shown. Moreover, continuous de-politicization of financial matters will be important, despite the current political instability in Hong Kong and the geopolitical environment becoming more antagonistic towards China.

\subsection{The potential global impact of the digital currency}

The introduction of DCEP thus comes at a time when some meaningful progress has been made in internationalizing the RMB, but significant headwinds exist in advancing it further. It remains unclear whether DCEP will be focused on China or become more widely adopted beyond its borders. If its adoption does internationalize, will DCEP then become just another infrastructure programme to facilitate RMB internationalization next to all the others, or will it constitute a larger breakthrough in raising the status of the RMB as an international trade, investment and reserve currency, potentially challenging the dominance of the US dollar?

56 Ibid., p. 89-93. 


\section{Impact on renminbi internationalization}

Given the setup of DCEP primarily as a payments system, if pushed to an international level it can be expected to further facilitate international payments in RMB. DCEP could offer companies importing to or exporting from China a simplified method for cross-border RMB-denominated settlement, with the added advantage of reducing currency exchange costs and risks by eliminating the need for the US dollar as an intermediary currency. ${ }^{57}$ The cost-effective nature of DCEP could help break through the entrenched network characteristics of the global currency system, in which it is often still more convenient to use the US dollar as an intermediary currency even when it would be possible to exchange third currencies directly into RMB. ${ }^{58}$ DCEP might become even more interesting for traders if it is incorporated into broader programmes for the digitization of trade with China, some of which are already being developed. ${ }^{59}$ China has been taking advantage of its leading role in international trade to intensify global demand for its currency, ${ }^{60}$ and DCEP provides an important opportunity to further intensify this strategy.

Beyond its adoption in international trade, individuals in other countries could also use DCEP for common payments and transactions, should the technology allow it. ${ }^{61}$ An accessible payments system in RMB could be particularly attractive in developing countries with underdeveloped financial infrastructures or unstable currencies. Here, DCEP could even function as an alternative to local currency, ${ }^{62}$ and its NFC functionality could provide digital payments to remote areas and unbanked populations in these countries. The global number of unbanked adults is at 1.7 billion, according to the World Bank, though around two thirds of them have access to a mobile phone. ${ }^{63}$ Most of them live in developing countries. DCEP might become increasingly popular especially in countries

57 John Xie, 'China's Digital Currency Takes Shape; Will It Challenge Dollar?', in Voice of America, 25 April 2020, https://www.voanews.com/economy-business/ chinas-digital-currency-takes-shape-will-it-challenge-dollar.

58 Di Dongsheng, 'The Economics and Politics of China's Currency Internationalization', cit.

59 Richard Turrin, 'China's CBDC', cit.

60 Paola Subacchi, The People's Money. How China is Building a Global Currency, New York, Columbia University Press, 2017.

61 John Xie, 'China’s Digital Currency Takes Shape; Will It Challenge Dollar?', cit.

62 Henry M. Paulson, 'The Future of the Dollar', cit.

63 World Bank, Financial Inclusion on the Rise, But Gaps Remain, Global Findex Database Shows, 19 April 2018, https://www.worldbank.org/en/news/press-release/2018/04/19/ financial-inclusion-on-the-rise-but-gaps-remain-global-findex-database-shows. 
with closer links to China, such as in Asia or along the Belt and Road, and in countries receiving large numbers of Chinese tourists. Cross-border payments traffic with China in RMB is already rising considerably in many Asian and African countries, ${ }^{64}$ and Chinese electronic payment companies Ant Financial and Tencent are making inroads into developing country markets in Africa and elsewhere. China UnionPay already has a vast global presence. The expansion of these payment services paves the way for a potential future adoption of DCEP in these countries.

Another way DCEP could have an international dimension is through its potential to circumvent the Society for Worldwide Interbank Financial Telecommunication (SWIFT) payments system used for most international transactions between financial institutions. ${ }^{65}$ This system is in many ways archaic and expensive, with transactions needing several days for completion, despite technologies with much shorter transaction times being currently available. DCEP could offer a faster and cheaper alternative to SWIFT.

All these considerations suggest that DCEP is likely to expand global payments in $\mathrm{RMB}$, but how the digital currency could play a role in advancing the RMB as an investment or reserve currency is less obvious. While companies, institutional and retail investors may draw on DCEP to invest into and out of China, the existence of a new method for cross-border transactions is unlikely to significantly affect investment decisions, which will continue to depend on the fundamentals of the Chinese financial system. DCEP will not eliminate the need for financial reforms, capital account liberalization and a more flexible exchange rate. Rather, these may become more necessary to make DCEP effective as a cross-border payments mechanism between China and the rest of the world. As it currently stands, DCEP would need to be subject to the same convertibility restrictions as the RMB. ${ }^{66}$

For similar reasons, DCEP will be less relevant in government choices on the reserve currencies they hold. Major reserve currencies will continue to be those backed by strong economic fundamentals, good financial governance and an open currency system. The adoption of DCEP as a payments system backed by the central bank is not likely to change that.

64 SWIFT, Beyond Borders: China Opens Up to the World, cit.

65 Richard Turrin, 'China’s CBDC', cit.

66 Marc Chandler, 'China's Digital Currency', in Nasdaq, 15 June 2020, https://www. nasdaq.com/articles/chinas-digital-currency-2020-06-15. 


\section{Implications for the global dominance of the US dollar}

DCEP's most promising strength is its potential to shift the world payments system in favour of the RMB. If it is successful in making RMB payments more convenient in other countries, DCEP could offer a readily available alternative to the US dollar for payment transactions. Many businesses conducting international trade with China would embrace an opportunity to cut transaction costs and enhance payment efficiency. Given that China is the world's largest exporter, international adoption of DCEP for trade settlement could scale up rapidly. In addition, individuals, especially in developing countries, will probably show interest. Gradually, the use of the RMB would rise at the expense of the US dollar.

To accelerate this process, Beijing could proactively encourage China's international economic partners to promote DCEP. Countries with particularly strong ties with China or those more critical of the United States and concerned about the dominance of the US dollar may well be receptive to such initiatives. ${ }^{67}$ Any future economic decoupling between the United States and China may create even greater space for DCEP to develop and spread, at least within areas where China has a strong influence, such as in some of the countries along the Belt and Road.

DCEP offers China an opportunity to provide a complete and potentially more efficient alternative to existing global payments systems, such as SWIFT and the Clearing House Interbank Payments System (CHIPS). As the governance of these established systems could be considered Western-centric, China should have an interest in developing alternatives. Its attempt to establish CIPS was one move towards creating such alternatives, but this system still collaborates with SWIFT and its adoption has been relatively modest. DCEP could provide a completely new and different mechanism, entirely removed from these traditional payments systems. It would enable China to circumvent and avoid the current system of international transactions (and become less vulnerable to Western sanctions).$^{68}$

However, although the future of DCEP looks promising in payments transactions, its potential to help the RMB challenge US dollar dominance as an international investment and reserve currency is more limited. Greater prominence of the RMB in these two areas would however be necessary to dethrone the US dollar, and international liquidity of the RMB would need to be higher.

67 Michael Greenwald, 'Digitizing the Dollar in the Age of COVID-19', in New Atlanticist, 22 April 2020, https://www.atlanticcouncil.org/?p=246767.

68 Yuan Yang and Hudson Lockett, 'What is China's Digital Currency Plan?', cit. 
DCEP cannot be expected to help China challenge the US dollar outright unless China significantly reforms and liberalizes its financial system.

Nevertheless, a strong global rollout and scaling up of DCEP in cross-border payments should offer China an important opportunity to eat into US dollar hegemony by gradually expanding the space for the RMB and slowly building up a viable alternative to the US dollar. ${ }^{69}$ Over a longer period of time, these efforts could lay the groundwork for a greater challenge to US dollar hegemony, especially once the time has finally come for China's financial system to undergo more decisive and persistent reforms.

\subsection{Conclusions and future outlook}

China will, without doubt, have a first-mover advantage in rolling out a CBDC. The large size of its population and extraordinary familiarity of its people with digital payment technologies and cashless transactions through smartphones and QR codes provides its central bank with a unique platform to test and scale up any rollout of DCEP. Alipay or WeChat Pay are standard, ubiquitous forms of payment in China, with mobile payments transactions having reached 41.5 trillion US dollars in $2018 .{ }^{70}$ Concerns over privacy are also less of a concern in China, ${ }^{71}$ which makes the country a practical testing ground for a DCEP that only promises 'controllable anonymity'.

A first-mover advantage might also enable China to internationalize digital currency payments before other countries' CBDCs emerge. China would then be able to define many relevant technological standards, placing it in a privileged position when it comes to determining the future direction of the technology. ${ }^{72}$

However, it is far from certain that DCEP will also trigger a major overhaul of international digital payments, and there will be challenges and downsides. To successfully internationalize DCEP, China would need to resolve the contradiction of how to rapidly expand international circulation of RMB despite a current account surplus and limited international capital flows. Beijing will also need to

69 Hannah Murphy and Yuan Yang, 'Patents Reveal Extent of China’s Digital Currency Plans', cit.

70 Henry M. Paulson, 'The Future of the Dollar', cit.

71 Marion Laboure and Jim Reid, The Future of Payments - Part III. Digital Currencies: the Ultimate Hard Power Tool, Deutsche Bank Research, January 2020, https://www. dbresearch.com/PROD/RPS_EN-PROD/PROD0000000000504589/The_Future_of_ Payments_-_Part_III_Digital_Currenc.PDF.

72 Roger Huang, 'China Will Use Its Digital Currency to Compete with the USD', cit. 
build confidence among overseas users of DCEP in the strength of the Chinese economy, its institutions, policies and financial system, the governance of the $\mathrm{RMB}$, and the functionalities and security of DCEP. Most importantly, Beijing will need to offer reassurance about what 'controllable anonymity' means for overseas users of DCEP, who may be more concerned than the average Chinese citizen about privacy and potential surveillance by the Chinese government.

In being the first country to roll out DCEP, China will also assume the risks should anything go wrong in what is a sensitive area of any national economy. Other countries will learn from China's roll-out of DCEP and adapt the positives to their circumstances while being able to anticipate and avoid any mistakes China may make. This will help speed up any subsequent development of competing digital currencies, including for the US dollar. Many central banks are already developing competing digital currencies, the IMF has been encouraging their development, ${ }^{73}$ and the G7 countries are discussing collaboration on CBDCs in direct response to China's efforts. ${ }^{74}$ Some advanced-economy CBDCs, even if launched belatedly, might draw on their stronger and more internationally integrated financial systems to leapfrog the DCEP.

China does not assume a leadership role in fintech, as its real advantage is scalability. The United States - itself a strong fintech power with a high volume of cashless payments using both mobile phone (e.g. Apple Pay) and card-based technologies - should be able to quickly follow China into the digital currency era, together with other countries. This might reduce the extent to which China will be able to capitalize on its first-mover advantage. The result may be a system of several, possibly quite integrated, digital currencies. But to achieve catch-up with China in digital currencies, the US government must develop greater policy determination to develop its own CBDC. Moreover, to keep the hegemony of its currency in the long run, the US will need to maintain overall confidence in its economic fundamentals, financial system, policies and institutions, and play a constructive leadership role in multilateral economic affairs.

In sum, an early launch of DCEP offers China an additional channel for the internationalization of the RMB and an opportunity to eat away at the US dollar's dominance in the international financial architecture. Initial focus is likely to be on international payments, but in the medium- to long-term, DCEP could help advance the RMB as an international investment and reserve currency, should

73 PwC, The Rise of Central Bank Digital Currencies (CBDCs)..., cit.

74 Cissy Zhou, 'China's Digital Currency Edges Closer with Large-Scale Test by Four State-Owned Banks', cit. 
China's domestic financial system become more favourable to such an objective and should the international liquidity of the currency improve. Although its firstmover advantage in developing DCEP will benefit China, there will be associated challenges as well. The final outcome will depend on how China leads the way into this new CBDC era, how other countries - including the United States - will respond, and how both the Chinese and US economies will evolve in the future. What remains quite certain is that we will soon witness some ground-breaking transformations in the global system for cross-border payments and potentially broader international financial infrastructure, spearheaded by China.

\section{References}

Bank for International Settlements (BIS), Foreign Exchange Turnover in April 2019, 16 September 2019, https://www.bis.org/statistics/rpfx19_fx.htm

Center for Strategic and International Studies (CSIS), 'Will China's Push to Internationalize the Renminbi Succeed?', in ChinaPower, 18 June 2020, https://wp.me/p8Side-1AP

Marc Chandler, 'China's Digital Currency', in Nasdaq, 15 June 2020, https:// www.nasdaq.com/articles/chinas-digital-currency-2020-06-15

Committee on Payments and Market Infrastructures, 'Central Bank Digital Currencies', in CPMI Papers, No. 174 (March 2018), https://www.bis.org/ cpmi/publ/d174.htm

Helen Davidson, 'China Starts Major Trial of State-run Digital Currency', in The Guardian, 28 April 2020, https://gu.com/p/dmgg3

Di Dongsheng, 'The Economics and Politics of China's Currency Internationalization', in Global Asia, Vol. 15, No. 2 (June 2020), p. 58-64, https://www.globalasia.org/v15no2/cover/the-economics-and-politics-ofchinas-currency-internationalization_di-dongsheng

Hung-Gay Fung et al., 'The Offshore Renminbi Bonds: The Dim Sum and Formosa Bonds', in The Chinese Economy, Vol. 49, No. 4 (2016), p. $287-299$

Sundeep Gantori et al., Information Technology. Understanding China's Digital Currency and Blockchain Initiatives, UBS, 23 April 2020, https://docplayer. net/191072050-Information-technology.html

Michael Greenwald, 'Digitizing the Dollar in the Age of COVID-19', in New Atlanticist, 22 April 2020, https://www.atlanticcouncil.org/?p=246767

Jonas Gross and Alexander Bechtel, 'China’s Digital Currency Project: What Is DC/EP All About?', in Medium, 4 June 2020, https://link.medium.com/ IbOTCm63Mab 
Michael Gu, 'China's National Digital Currency DCEP/CBDC Overview', in Boxmining, 13 October 2020, https://boxmining.com/dcep/\#What_is_DCEP

Hu Yue and Luo Meihan, 'China Gives Away \$1.5 Million to Test Digital Currency', in Caixin Global, 9 October 2020, https://www.caixinglobal. com/2020-10-12/china-gives-away-15-million-to-test-digital-currency101613663.html

Roger Huang, 'China Will Use Its Digital Currency to Compete with the USD', in Forbes, 25 May 2020, https://www.forbes.com/sites/rogerhuang/2020/05/ 25/china-will-use-its-digital-currency-to-compete-with-the-usd

Maximilian Kärnfelt, 'China’s Currency Push. The Chinese Yuan Expands Its Footprint in Europe', in China Monitor, 9 January 2020, https://merics.org/ en/report/chinas-currency-push

Shuyao Kong, 'DCEP: An Inside Look at China's Digital Currency', in Decrypt, 28 June 2020, https://decrypt.co/33866

Jan Knoerich and FranciscoUrdinez, 'Contesting Contested Multilateralism: Why the West Joined the Rest in Founding the Asian Infrastructure Investment Bank', in The Chinese Journal of International Politics, Vol. 12, No. 3 (Autumn 2019), p. 333-370

Marion Laboure and Jim Reid, The Future of Payments - Part III. Digital Currencies: the Ultimate Hard Power Tool, Deutsche Bank Research, January 2020, https://www.dbresearch.com/PROD/RPS_EN-PROD/ PROD0000000000504589/The_Future_of_Payments_-_Part_III__Digital_ Currenc.PDF

George Magnus, Red Flags. Why Xi's China is in Jeopardy, New Haven, Yale University Press, 2018

Daniel McDowell, 'The (Ineffective) Financial Statecraft of China's Bilateral Swap Agreements', in Development and Change, Vol. 50, No. 1 (January 2019), p. 122-143

Hannah Murphy and Yuan Yang, 'Patents Reveal Extent of China's Digital Currency Plans', in Financial Times, 12 February 2020, https://www.ft.com/ content/f10e94cc-4d74-11ea-95a0-43d18ec715f5

Mohammad Musharraf, 'Digital Yuan's Backend Development Complete, Says Chinese Official', in CoinTelegraph, 22 June 2020, https://cointelegraph.com/ news/digital-yuans-backend-development-complete-says-chinese-official

Ramon Pacheco Pardo, Jan Knoerich and Yuanfang Li, 'The Role of London and Frankfurt in Supporting the Internationalisation of the Chinese Renminbi', in New Political Economy, Vol. 24, No. 4 (2019), p. 530-545

David Pan, 'China's Blockchain Infrastructure to Extend Global Reach', in CoinDesk, 21 July 2020, https://www.coindesk.com/ chinas-blockchain-infrastructure-to-extend-global-reach-with-six-public-chains 
Henry M. Paulson, 'The Future of the Dollar', in Foreign Affairs, 19 May 2020, https://www.foreignaffairs.com/node/1126037

PwC, The Rise of Central Bank Digital Currencies (CBDCs). What You Need to Know, November 2019, https://www.pwc.com/gx/en/financial-services/pdf/ the-rise-of-central-bank-digital-currencies.pdf

Henny Sender, 'China's New Digital Currency Takes Aim at Alibaba and Tencent', in Financial Times, 4 August 2020, https://www.ft.com/content/ fec06de9-ac43-4ab8-81f3-577638bd3c16

Ye Shi and Shucheng Zhou, Central Bank Digital Currencies: Towards a Chinese Approach. Design Choices of Digital Currency Electronic Payment, Master Thesis, Jönköping University International Business School, May 2020, http://urn.kb.se/resolve?urn=urn:nbn:se:hj:diva-48662

Paola Subacchi, The People's Money. How China is Building a Global Currency, New York, Columbia University Press, 2017

SWIFT, Beyond Borders: China Opens Up to the World, RMB Tracker special edition, June 2019, https://www.swift.com/swift-resource/227391/download

SWIFT, RMB Tracker, July 2020, https://www.swift.com/swift-resource/249256/ download

Chuan Tian, 'China's Central Bank Opens New Digital Currency Research Institute', in CoinDesk, 30 June 2017, https://www.coindesk.com/ chinas-central-bank-opens-new-digital-currency-research-institute

Ryan Todd and Mike Rogers, A Global Look at Central Bank Digital Currencies. From Iteration to Implementation, The Block Research for KPMG and Blockset, August 2020, https://www.tbstat.com/wp/uploads/2020/08/KPMGCBDC-Report.FINAL_.v.1.02.pdf

Richard Turrin, 'China's CBDC', in PCN Magazine, Vol. 6, No. 2 (July 2020), p. 6-9, https://www.teampcn.com/magazine/magazine/china-s-cbdc

Katie-Ann Wilson, 'China’s Next World-First', in OMFIF Articles, 3 July 2020, https://www.omfif.org/2020/07/chinas-next-world-first

World Bank, Financial Inclusion on the Rise, But Gaps Remain, Global Findex Database Shows, 19 April 2018, https://www.worldbank.org/en/news/pressrelease/2018/04/19/financial-inclusion-on-the-rise-but-gaps-remain-globalfindex-database-shows

Yuan Yang and Hudson Lockett, 'What is China's Digital Currency Plan?', in Financial Times, 25 November 2019, https://www.ft.com/content/ e3f9c3c2-0aaf-11ea-bb52-34c8d9dc6d84

Yao Qian, 'Central Bank Digital Currency: Optimization of the Currency System and Its Issuance Design', in China Economic Journal, Vol. 12, No. 1 (2019), p. 1-15 
Yao Qian, 'A Systematic Framework to Understand Central Bank Digital Currency', in Science China Information Sciences, Vol. 61, Article 033101 (2018)

John Xie, 'China's Digital Currency Takes Shape; Will It Challenge Dollar?', in Voice of America, 25 April 2020, https://www.voanews.com/economybusiness/chinas-digital-currency-takes-shape-will-it-challenge-dollar

Cissy Zhou, 'China's Digital Currency Edges Closer with Large-Scale Test by Four State-Owned Banks', in South China Morning Post, 6 August 2020, https://www.scmp.com/economy/china-economy/article/3096296/ chinas-digital-currency-edges-closer-large-scale-test-four

Raymond Zhong, 'China’s Cryptocurrency Plan Has A Powerful Partner: Big Brother', in The New York Times, 18 October 2019, https://nyti.ms/32sFMnw 


\section{Nicola Bilotta}

\section{Chapter 8: CBDCs and Stablecoins: The Scramble for (Controllable) Anonymity}

In an increasingly digitalized society, citizen-consumers create an enormous volume of data, enabling the empowerment of new business opportunities produced by data aggregation and analysis. This unprecedented megatrend has already raised several questions around data governance, concerning the rules that frame availability, management, accessibility, security and usability of data. These concerns are heightened when considering the accumulation of financial data, which is experiencing a remarkable growth in both volume and quality, due to the increasing digitalisation of payments. Cash - in the form of banknotes and coins - has the unique feature of full anonymity. Someone can pay for goods or services without disclosing one's identity or personal/financial information. This is something that credit/debit cards and mobile payment apps do not have. Whenever a transaction is intermediated by a third-party, the latter gathers and stores data on that transaction. Cash then reduces the information asymmetry between governments and private corporations, and citizens.

On the one hand, a progressively cashless society can help mitigate the risks of tax evasion and money laundering, as regulators would be able more easily to monitor and keep track of citizens' transactions. On the other hand, the existing digital payment solutions are developed and owned by private actors incumbent financial institutions, big technology companies and non-banking actors - enabling these players to establish an intermediary function between governments and public money. Furthermore, these private players can collect valuable data that can empower their models of behavioural profiles. This is particularly relevant for big tech and non-bank actors that will be able to develop a more comprehensive profile of consumers through a cross-sources analysis, combing through information on what consumers like, desire, buy and can afford. Financial data is valuable because it provides an accurate picture of consumer's habits and financial situation. The growing public policy concerns on the effects of this payment disintermediation increase if private non-banking actors are also seeking to launch private digital currencies that could potentially create parallel money systems, operating on a new architecture rather than on traditional infrastructures and networks. 
Governments are worried that, if this trend of cashless payments keeps expanding, private actors would dominate the digital payment market, producing risks related to data aggregation and accumulation. To strengthen the role of central bank money as a relevant unit of account in a digital society, central banks are exploring the development of domestic general purpose central bank digital currencies (CBDCs). Despite CBDCs being a public-issued form of money, they also produce risks around how much information central governments can retain from consumer's transactions. This makes it challenging to find and establish a balance between controllable anonymity and compliance with the current anti-money laundering (AML) rules. Apparently, CBDCs could be technically designed to blind or regulate states' supervision to allow users some degree of privacy and anonymity. ${ }^{1}$ Yet the equilibrium of the degree of anonymity in relation to efficiency and security in a CBDC system appears to primarily be a political decision rather than a technical and design issue. The underlying infrastructure is determined by a conscious choice. Most of the current literature and discussion on privacy/anonymity and CBDCs has been focused on the possible technical solutions to guarantee security and to limit accessibility. ${ }^{2}$ Those engaged in this discussion should however take a step back first and focus on which degree of privacy/anonymity monetary systems should guarantee to citizens. In terms of their different natures and the risks they produce, both CBDCs and private-owned stablecoins raise concerns on anonymity, data aggregation and balance of power: how much privacy should be available, and from whom, are key public policy issues. Nevertheless, whereas the debate on stablecoins at the multilateral level appears to have recognized the political dimension of this innovation, the discussion on CBDCs seems to lack a political approach to anonymity.

\subsection{Anonymity in CBDCs and privately owned stablecoins}

One often hears the common - and yet simplistic and misconceived - argument that the only people who care about anonymous payment systems are

1 European Central Bank (ECB), 'Exploring Anonymity in Central Bank Digital Currencies', In Focus Papers, No. 4 (December 2019), https://www.ecb.europa.eu/paym/ intro/publications/pdf/ecb.mipinfocus191217.en.pdf.

2 Ibid.; Committee on Payments and Market Infrastructures, 'Central Bank Digital Currencies', in CPMI Papers, No. 174 (March 2018), https://www.bis.org/cpmi/publ/ d174.htm. 
those who are violating the law. ${ }^{3}$ This has been an extremely popular reasoning to stigmatize the development of untraceable means of digital payment - such as Bitcoins - as a sort of anarcho-utopian project. However, in the book Privacy and Freedom, published in 1967, Alan Westin asserted that privacy is an individual freedom: 'the claim of individuals [...] to determine for themselves when, how, and [to] what extent information about them [citizens] is communicated to others. ${ }^{4}$ That commercial payment platforms monetize data is no secret. They either sell data to third parties for cross-source aggregation or use payment data to cluster users and sell these consumer profiles to third parties. Google, for instance, bought data on millions of card transactions from Mastercard. The deal aimed at tracking when and whether the online advertisements powered by Google resulted in a sale in physical shops. ${ }^{5}$ Although both Google and Mastercard guaranteed the privacy and the safety of the financial data, Google has started offering a service called 'Store Sales Measurement', which allows it to anonymously match ads and actual store sales. ${ }^{6}$ Clients have, however, not been informed that their banking data has been sold and shared with a third party. Similarly, in China, the flow of data in Alibaba's various activities has been feeding and empowering its large ecosystem, such as with the transfer of data from Alibaba's e-commerce stores and Alipay to MyBank to assess creditworthiness, or from Alipay to Sesame Credit. ${ }^{7}$ This market is still underdeveloped, and it is likely to grow very fast, driven by the increasing scale of data accumulation and by the advancement of prediction tools.

Whether (controllable) anonymity is a right or an individual freedom in the realm of payments is arguable, but the digitalisation of payments is de facto altering the equilibrium between privacy and security that has endured for centuries in the relationship of citizen-consumers, governments and private

3 Felix Salmon, 'Why Payments Won't Ever Be Anonymous', in Reuters, 16 December 2011, http://reut.rs/1pjAtfX.

4 Alan F. Westin, Privacy and Freedom, New York, Atheneum, 1967, p. 7.

5 Mark Bergen and Jennifer Surane, 'Google and Mastercard Cut a Secret Ad Deal to Track Retail Sales', in Bloomberg, 30 August 2018, https://www.bloomberg.com/news/ articles/2018-08-30/google-and-mastercard-cut-a-secret-ad-deal-to-track-retail-sales.

6 Sridhar Ramaswamy, 'Powering Ads and Analytics Innovations with Machine Learning', in Google Blog, 23 May 2017, https://blog.google/products/marketingplatform/360/ powering-ads-analytics-innovations-with-machine-learning-xp.

7 John Gapper, 'Alibaba's Social Credit Rating Is a Risky Game', in Financial Times, 21 February 2018, https://www.ft.com/content/99165d7a-1646-11e8-9376$4 a 6390 a d d b 44$. 
companies. With the traceability produced by digital payments, several questions can be raised. How is the financial data collected used? Could 'financial surveillance' be a threat? In that case, can that threat be mitigated? Could digital currencies affect the balance of power in the relationship of individuals with state and private corporations? This range of questions is more relevant now than ever, considering a future society in which digital currencies are widely used, increasing risks of misbehaviour in data exploitation by private corporations as well as by public authorities.

The development of private-owned stablecoins within a larger ecosystem could be a turning point in monetary systems as this form of digital money could reach scale very quickly. The first intrinsic advantage of stablecoins is that they can assure a less volatile asset to users, providing these digital currencies with a potential function of medium of exchange and of store of value. Nevertheless, the attractiveness of these initiatives is causally linked to two factors that affect money circulation. First, the credibility of the issuer. Consumers need to trust that they can convert their digital tokens into fiat money anytime they like, and that the value of the stablecoin is indeed stable and backed by reserves. Second, the degree of acceptance. Users could be incentivized to adopt a stablecoin that is backed by a corporation that has a pre-existing relationship with a large consumer base and has high brand recognition, as this could mitigate the perceived risks related to its governance and, at the same time, it could empower an ecosystem of services and products accessible through this digital currency, exploiting network effects. Such characteristics could allow both diffusion of information and adoption, reducing the common entry barriers to traditional currency. ${ }^{8}$

If the intermediation of private players is already dominating electronic and mobile payments, stablecoins could provide large private tech corporations with the opportunity to generate and record unique data on transactions directly on their independent infrastructure, facilitating the empowerment of faster, cheaper and more efficient solutions for data predictive analysis and tools. Network externalities are stronger when an ecosystem offers an integrated platform of services and products, creating value through knowledge. Digital payment solutions then become a tool to strengthen the business models of these players, which aim at building an 'aggregator of mutually complementary activities'.

8 Tobias Adrian and Tommaso Mancini-Griffoli, 'Digital Currencies: The Rise of Stablecoins', in IMF Blog, 19 September 2019, https://blogs.imf.org/?p=27149. 
A further consolidation of digital payment solutions through stablecoins developed by private players could lead to a deeper concentration of crosssources data aggregation, creating far-reaching implications for how data will be used within the ecosystem or shared with third parties. ${ }^{9}$ Even though both established e-wallets (such as Google Pay or Apple Pay) and stablecoin's pivotal projects (such as Libra - recently renamed Diem - ) have given assurances that they will not share or monetize financial data, these intermediaries could anyway ultimately access and gather information to empower their ecosystem. For example, if users integrate Calibra, Facebook's e-wallet, with their Messenger or WhatsApp accounts, Facebook will be able to track basic information, such as with whom or at which shop users have started a transaction, without needing specific approval by users themselves. Furthermore, in the name of convenience, large tech corporations are likely to encourage users to allow the free flow of information within their ecosystem's activities with the promise of rewards.

Despite private banking and non-banking players claiming that personal data is only used in an anonymized form, data is normally only protected by pseudonymized keys. To highlight how weak the system is, some experts were able to correctly track names or card numbers of 90 per cent of 1.1 million credit card holders only based on their 'anonymized' card transactions made over three months. ${ }^{10}$ In addition to a set of technical concerns related to data protection, the aggregation of financial data could produce newer risks of anti-competitive use of data. Exploiting network effects and market dominance, big tech companies could be incentivized to engage in price discrimination (charging consumers different prices for the same product) due to the increasing information asymmetry between consumers and companies. ${ }^{11}$ Think about Uber's 'route-based pricing. This system uses various factors to set rates based on a prediction that evaluates how much a user will be willing to spend. Or consider the petition filed

9 G7 Working Group on Stablecoins, 'Investigating the Impact of Global Stablecoins', in CPMI Papers, No. 187 (18 October 2019), p. 15, https://www.bis.org/cpmi/publ/d187. htm.

10 Heike Mai, 'Cash Empowers the Individual Through Data Protection', in Talking Point, 2 July 2019, https://www.dbresearch.com/PROD/RPS_EN-PROD/ PROD0000000000495958/Cash_empowers_the_individual_through_data_protecti. xhtml.

11 Bank for International Settlements (BIS), 'Big Tech in Finance: Opportunities and Risks', in Annual Economic Report 2019, June 2019, p. 67, https:/www.bis.org/publ/arpdf/ ar2019e3.htm. See google patent: https://pdfpiw.uspto.gov/.piw?docid=08260657. 
by Consumer Education Foundation with the Federal Trade Commission on Walmart's online shop. The former found that users could purchase a set of basic goods at different prices. Anonymous users were offered lower prices. ${ }^{12}$ In this sense, aggregating financial data would radically increase the potential of predictive analysis models, maximizing the efficiency of their ecosystems. Therefore, to accurately assess and understand the possible effects of stablecoins connected to pre-existing ecosystems, the framework under which financial data is regulated in these ecosystems needs to be analysed in the wider context of a data-driven economy and of the competitive use of data, as showed by several studies carried out by international supervisory bodies. ${ }^{13}$

CBDCs could however mitigate the abovementioned issues by providing 'what the private sector cannot: privacy in payments. ${ }^{14}$ Thus, CBDCs could aim at counterbalancing the current dominance of private players in the mobile payment market. ${ }^{15}$ Central banks are not profit-driven. They do not monetize the data they gather. Instead, their main aim is to ensure a robust and safe monetary system. By being able to track CBDC data more efficiently, central banks could better monitor the status of their domestic economy, reducing the existing information asymmetry when deciding on a monetary policy intervention. Data aggregation for central banks makes a lot of sense. A tighter control on transaction histories could improve their ability to fight money laundering and tax evasion, at the same time reducing the size of the informal economy.

While all this is true, central banks would also be able to access and collect information unavailable before, empowering a newer and deeper identification of users and payment flows. Beyond spending habits, it would enable location tracking and the accumulation of sensitive personal data. If misused, CBDCs could adversely foster an unprecedented centralisation of information in the government's hands. It is not a matter of predicting an Orwellian

12 REPRESENT project, Secret Surveillance Scoring: Urgent Request for Investigation and Enforcement Action, 24 June 2019, https://www.representconsumers.org/wp-content/ uploads/2019/06/2019.06.24-FTC-Letter-Surveillance-Scores.pdf.

13 Maurice E. Stucke, 'Should We Be Concerned About Data-opolies?', in Georgetown Law Technology Review, Vol 2, No. 2 (2018), p. 275-324, https://wp.me/p8IxBy-zh.

14 Christine Lagarde, 'Winds of Change. The Case for New Digital Currency', in IMF Speeches, January 2019, p. 5, http://dx.doi.org/10.5089/9781484389171.076.

15 Alexander Kriwoluzky and Chi Hyun Kim, 'Public or Private? The Future of Money', in Monetary Dialogue Papers, December 2019, https://doi.org/10.2861/880099. 
scenario, but of assessing potential risks related to a rise of public visibility into a financial system, altering the relation of power between citizens and governments. If financial transactions are fully traceable, public authorities may be incentivized to abuse data and, in some cases, it may facilitate political surveillance in domestic markets. Moreover, if retail and corporate consumers use a foreign $\mathrm{CBDC}$, foreign governments may be able to directly gather data on those transactions (such as in projects for cross-border interbank settlement, migrant remittance, or in case of tourists or business travellers). If a domestic CBDC has different customer data privacy policies and safeguards, then foreign user data may be vulnerable when people use those CBDCs. For example, in 2018, the Office of the Privacy Commissioner of Canada advised its citizens to buy legal cannabis using cash, fearing that some countries could deny consumers entry if they find out that those consumers have purchased legal cannabis. ${ }^{16}$

These concerns are amplified in authoritarian regimes, where governments could drastically increase the efficiency of their surveillance and repression tools. For instance, if a citizen attends a political protest, the central bank could immediately freeze their CBDC account. Even in democratic countries governed by the rule of law, an extreme centralisation of payment history data could produce risks. Democracy is more fragile than many realize. The reduction of the information asymmetry would provide public authorities with additional power over citizens. There is a big difference between trusting a government to not misuse transaction data and trusting it to develop a system that is built to protect information. ${ }^{17}$ Therefore, to mitigate risk, CBDCs should have privacy safeguards with compliance measures included in their design from the outset. This approach could ensure a more secure functional design. If, instead, privacy and compliance are added at a second stage, it could leave in loopholes. ${ }^{18}$

16 Canada's Office of the Privacy Commissioner (OPC), Protecting Personal Information: Cannabis Transactions, December 2018, https://www.priv.gc.ca/en/ privacy-topics/collecting-personal-information/gd_can_201812.

17 Charles Kahn, 'Payment Systems and Privacy', in Federal Reserve Bank of St. Louis Review, Vol. 100, No. 4 (Fourth Quarter 2018), p. 337-344. https://doi.org/10.20955/ r.100.337-44.

18 Ann Cavoukian, Privacy by Design. The 7 Foundational Principles, updated January 2011, https://www.ipc.on.ca/wp-content/uploads/Resources/7foundationalprinciples. pdf. 


\subsection{Why is anonymity not a design issue?}

Most of the current research underlines that a system can seek counterparty anonymity and/or third-party anonymity in payments. The former implies that payers do not reveal their identities to recipients. The latter instead implies that the true identities of payers and recipients are not accessible to parties not directly involved in the transaction. Whereas counterparty anonymity seems to be less controversial, third-party anonymity has remarkable implications as it directly affects the efficiency of AML procedures..$^{19}$ While it is easier to consciously blind counterparties - such as blinding merchants from accessing the true identity and transaction history of the payer - hiding this information from the government could be more complicated. These concerns drive the discussion over the choice between a token-based or account-based CBDC (see Chapter 1 in this volume). The former could provide better privacy for users by default, offering the opportunity to establish varying degrees of anonymity. This system would however increase risks related to financial integrity. The latter would, despite varying degrees of anonymity shaped by its design, resemble a model similar to deposits. ${ }^{20}$ The two systems could also co-exist, exploiting their comparative advantages. In a recent paper, the Bank of Canada proposed an architecture in which larger transactions would be carried out through an account-based CBDC, while smaller-value transactions could use anonymous token-based options. ${ }^{21}$ Where to set the cap for the token-account transactions or the amount at which AML rules would come into play is yet to be decided. ${ }^{22}$

In the vibrant research on possible design to protect users' privacy in CBDC's systems, the European Central Bank has developed an interesting proposal. The

19 Morten Linnemann Bech and Rodney Garratt, 'Central Bank Cryptocurrencies', in BIS Quarterly Review, September 2017, p. 55-70, https://www.bis.org/publ/qtrpdf/r_ qt1709f.htm.

20 Santiago Fernández de Lis and Pablo Urbiola, 'Retail Central Bank Digital Currencies: Means of Payment vs Store of Value', in SUERF Policy Notes, No. 183 (July 2020), https://www.suerf.org/policynotes/15609/retail-central-bank-digitalcurrencies-means-of-payment-vs-store-of-value; Raphael Auer and Rainer Böhmep, 'The Technology of Retail Central Bank Digital Currency', in BIS Quarterly Review, March 2020, p. 93, https://www.bis.org/publ/qtrpdf/r_qt2003j.htm.

21 John Miedema et al., 'Designing a CBDC for Universal Access', in Bank of Canada Staff Analytical Notes, No. 2020-10 (June 2020), https://www.bankofcanada.ca/?p=212517.

22 Raphael Auer, Giulio Cornelli and Jon Frost, 'Rise of the Central Bank Digital Currencies: Drivers, Approaches and Technologies', in BIS Working Papers, No. 880 (August 2020), https://www.bis.org/publ/work880.htm. 
ECB acknowledged that 'the payments ecosystem needs to find an answer to an issue that concerns all citizens: the question of how to allow some degree of privacy in electronic payments, while still ensuring compliance with AML/ CFT regulations. ${ }^{23}$ The technical solution proposed is to develop 'anonymity vouchers' for low-value transactions, while high-value transactions would be subjects to standard AML checks. Users would be granted time- and quantitylimited vouchers monthly, regardless of their account balances. These vouchers would not be transferable to other users and their value would be one voucher per one unit of CBDC. In the scenario described, the CBDC system would have four main features: (i) balances are not remunerated; (ii) it would be a two tier system; (iii) the ECB would be the only authorized issuer of CBDC units; and (iv) an ad hoc AML authority would monitor the parties involved in high value transactions. A two-tier system requires an intermediary to provide a user with a pseudonymous identity to be used as a network address for CBDC transactions. In case a transaction is carried out without an anonymity voucher, the intermediary will initiate the transfer via the AML authority, which will ultimately authorize or reject the transaction. ${ }^{24}$

In addition to a set of technical areas of improvement, a key question that could be raised in this scenario is of which factors the ECB will use to decide the limits of anonymity vouchers accessible to users. This will be a political decision rather than a technical one.

\subsection{Multilateralism for (controllable) anonymity in CBDCs}

If technical solutions exist to selectively blind governments and private corporations in digital currency systems, ${ }^{25}$ the key questions are where the boundaries between anonymity and security are, and how to ensure that those boundaries are respected. ${ }^{26}$ Full anonymity in digital currency systems is not desirable, as it could potentially ease illegal transactions and undermine compliance with regulations (KYC and AML). Similarly, no anonymity at all would

23 ECB, 'Exploring Anonymity in Central Bank Digital Currencies', cit., p. 3.

24 Ibid., p. 8.

25 Sarah Allen et al., 'Design Choices for Central Bank Digital Currency: Policy and Technical Considerations', in NBER Working Papers, No. 27634 (August 2020), https:// www.nber.org/papers/w27634.

26 Sriram Darbha and Rakesh Arora, 'Privacy in CBDC Technology', in Bank of Canada Staff Analytical Notes, No. 2020-9 (June 2020), https://www.bankofcanada.ca/ $? \mathrm{p}=212142$. 
produce unnecessary risk. Despite raising different sets of concerns on the effects of data visibility, both CBDCs and privately owned stablecoins would require a set of common rules to establish international standards on the degree of anonymity and privacy these systems should guarantee. On the one hand, the awareness has rapidly emerged that stablecoin's financial data accumulation is first a political matter, fostering an extensive debate on how to regulate identity and management of transaction data to mitigate the risks of moral hazard. ${ }^{27}$ Although the international dialogue on this matter is not easy, several international organisations are collaborating to set global responses to the challenges produced by stablecoins. ${ }^{28}$ Setting aside mitigation of money laundering and tax evasion risks and interoperability, ${ }^{29}$ the political dimension of anonymity in CBDCs has been reduced to a discussion on design and technical solutions. While this is true, the answer lies in the technological infrastructure of a CBDC. However, the shape that an infrastructure takes is the result of an ex ante political decision, as clearly acknowledged by the IMF in a recent study. ${ }^{30}$

Moreover, the effects of the varying degrees of anonymity blur the boundaries of a domestic market. As fiat money operates in a globalized and interconnected world economy, national/regional CBDCs, being also accessed by foreign retail and corporate customers, could produce adverse effects both domestically and internationally. Therefore, to avoid potential misuse of data and ensure fair and transparent systems, international supervisory bodies should promote a

27 Financial Action Task Force (FATF), FATF Report to G20 on So-called Stablecoins, June 2020, http://www.fatf-gafi.org/publications/virtualassets/documents/report-g20-socalled-stablecoins-june-2020.html; G7 Working Group on Stablecoins, 'Investigating the Impact of Global Stablecoins', cit.; Financial Stability Board (FSB), Addressing the Regulatory, Supervisory and Oversight Challenges Raised by "Global Stablecoin" Arrangements, 14 April 2020, https://www.fsb.org/? $\mathrm{p}=20011$.

28 Such as: Basel Committee on Banking Supervision (BCBS), the Committee on Payments and Market Infrastructures (CPMI), the International Organization of Securities Commissions (IOSCO), the Financial Action Task Force (FATF), the Organization for Economic Co-operation and Development (OECD) and the Financial Stability Board (FSB).

29 FATF website: Regulation of Virtual Assets, https://www.fatf-gafi.org/publications/ fatfrecommendations/documents/regulation-virtual-assets.html; and, Public Consultation on FATF Draft Guidance on Digital Identity, https://www.fatf-gafi.org/ publications/fatfrecommendations/documents/consultation-digital-id-guidance.html.

30 JohnKiffetal.,'ASurveyofResearchonRetailCentralBankDigitalCurrency',inIMFWorking Papers, No. 20/104 (2020), p. 31, https://www.imf.org/en/Publications/WP/Issues/ 2020/06/26/A-Survey-of-Research-on-Retail-Central-Bank-Digital-Currency-49517. 
multilateral effort to specifically discuss and establish the level of privacy that a CBDC system should provide. Even though anonymity and privacy concerns radically differ across countries due to diverse cultural, socio-economic and political contexts, a multilateral policy compromise could help achieve not an optimal solution, but basic shared pillars on how much privacy CBDC infrastructure should be designed to guarantee. This effort should be led by central banks and international organisations together with civil society, governments and private financial intermediaries. By this, citizens would be incentivized to trust CBDCs in domestic and foreign markets.

Finding a consensus on as highly sensitive and core subject as the rules for a national digital sovereign currency would be extremely complicated. Some countries would refuse to comply with any global standards. As in the current situation in the broader multilateral governance of digital space, where the major powers (the United States, China, and the EU) have different approaches and tend to pursue divergent interests, a multilateral dialogue on the degree of anonymity in CBDCs is likely to hit roadblocks. However, the establishment of a few common pillars adopted by a club of countries could guide more national legislations through spill-over effects. As highlighted by Hathaway and Shapiro, most current international laws have been shaped by this approach of 'shared interests and decentralized enforcement. ${ }^{31}$ Following Buchanan's economic theory of clubs, this 'club' of countries could influence the development of standards in other jurisdictions by cutting off access to their network of CBDCs to nations that do not comply with their rules. Partial or full exclusion from a shared network would undermine the economic benefits of the CBDC, incentivizing membership to gain the potential advantages of being in the club. ${ }^{32}$

\section{Conclusion}

Cash has created an information asymmetry among citizens, governments and private players, ensuring a degree of anonymity in transactions. The development of digital currencies, particularly CBDCs and privately owned stablecoins, could radically transform this equilibrium, allowing great visibility into financial data transactions. Whereas the implications of private corporations' data accumulation have raised several concerns among international and national

31 Oona Hathaway and Scott J. Shapiro, 'Welcome to the Post-Leader World', in Foreign Policy, 4 July 2020, https://foreignpolicy.com/2020/07/04/after-hegemony.

32 James M. Buchanan, 'An Economic Theory of Clubs', in Economica, New Series, Vol. 32, No. 125 (February 1965), p. 1-14. 
policymakers, the discussion on the political dimension of anonymity in CBDCs appears to have been marginalized. Nevertheless, if the technological solutions to consciously blind governments exist, the degree of anonymity designed into the system must be determined by an ex ante political choice.

No anonymity produces privacy risks for users, ultimately threating individual freedom. It is therefore widely acknowledged that CBDCs need to guarantee some privacy to their users. However, there is no consensus in on which the degree of privacy. To avoid moral hazard and the political misuse of visibility in transaction data, a multilateral effort is needed to set the limits of anonymity that CBDCs should provide. CBDCs being a matter of sovereignty, it would be extremely difficult to find a global consensus on the issue. A solution could be to promote shared standards and boundaries on guaranteed privacy within a club of countries. Membership in such a network would foster economic advantages related to full interoperability, while non-members would have only partial or no access to the network.

This is the time to start such a discussion. In this period of intense research and development, before individual countries launch national CBDCs, countries should develop a common framework in which the boundaries of privacy and anonymity are set. As it is essential that privacy and anonymity by designed into the infrastructure at the very onset, this multilateral exercise must take place before it is too late.

\section{References}

Tobias Adrian and Tommaso Mancini-Griffoli, 'Digital Currencies: The Rise of Stablecoins', in IMF Blog, 19 September 2019, https://blogs.imf.org/?p=27149

Sarah Allen et al., 'Design Choices for Central Bank Digital Currency: Policy and Technical Considerations', in NBER Working Papers, No. 27634 (August 2020), https://www.nber.org/papers/w27634

Raphael Auer and Rainer Böhmep, 'The Technology of Retail Central Bank Digital Currency', in BIS Quarterly Review, March 2020, p. 85-100, https:// www.bis.org/publ/qtrpdf/r_qt2003j.htm

Raphael Auer, Giulio Cornelli and Jon Frost, 'Rise of the Central Bank Digital Currencies: Drivers, Approaches and Technologies', in BIS Working Papers, No. 880 (August 2020), https://www.bis.org/publ/work880.htm

Bank for International Settlements (BIS), 'Big Tech in Finance: Opportunities and Risks', in Annual Economic Report 2019, June 2019, p. 55-79, https:// www.bis.org/publ/arpdf/ar2019e3.htm 
Mark Bergen and Jennifer Surane, 'Google and Mastercard Cut a Secret Ad Deal to Track Retail Sales', in Bloomberg, 30 August 2018, https://www.bloomberg.com/news/articles/2018-08-30/ google-and-mastercard-cut-a-secret-ad-deal-to-track-retail-sales

James M. Buchanan, 'An Economic Theory of Clubs', in Economica, New Series, Vol. 32, No. 125 (February 1965), p. 1-14

Canada's Office of the Privacy Commissioner (OPC), Protecting Personal Information: Cannabis Transactions, December 2018, https://www.priv.gc.ca/ en/privacy-topics/collecting-personal-information/gd_can_201812

Ann Cavoukian, Privacy by Design. The 7 Foundational Principles, updated January 2011, https://www.ipc.on.ca/wp-content/uploads/Resources/ 7 foundationalprinciples.pdf

Committee on Payments and Market Infrastructures, 'Central Bank Digital Currencies', in CPMI Papers, No. 174 (March 2018), https://www.bis.org/ cpmi/publ/d174.htm

Sriram Darbha and Rakesh Arora, 'Privacy in CBDC Technology', in Bank of Canada Staff Analytical Notes, No. 2020-9 (June 2020), https://www. bankofcanada.ca/?p=212142

European Central Bank (ECB), 'Exploring Anonymity in Central Bank Digital Currencies', In Focus Papers, No. 4 (December 2019), https://www.ecb. europa.eu/paym/intro/publications/pdf/ecb.mipinfocus191217.en.pdf

Santiago Fernández de Lis and Pablo Urbiola, 'Retail Central Bank Digital Currencies: Means of Payment vs Store of Value', in SUERF Policy Notes, No. 183 (July 2020), https://www.suerf.org/policynotes/15609/ retail-central-bank-digital-currencies-means-of-payment-vs-store-of-value

Financial Action Task Force (FATF), FATF Report to G20 on So-called Stablecoins, June 2020, http://www.fatf-gafi.org/publications/virtualassets/ documents/report-g20-so-called-stablecoins-june-2020.html

Financial Stability Board (FSB), Addressing the Regulatory, Supervisory and Oversight Challenges Raised by "Global Stablecoin" Arrangements, 14 April 2020, https://www.fsb.org/?p=20011

G7 Working Group on Stablecoins, 'Investigating the Impact of Global Stablecoins', in CPMI Papers, No. 187 (18 October 2019), https://www.bis. org/cpmi/publ/d187.htm

John Gapper, 'Alibaba's Social Credit Rating Is a Risky Game’, in Financial Times, 21 February 2018, https://www.ft.com/content/ 99165d7a-1646-11e8-9376-4a6390addb44 
Oona Hathaway and Scott J. Shapiro, 'Welcome to the Post-Leader World', in Foreign Policy, 4 July 2020, https://foreignpolicy.com/2020/07/04/ after-hegemony

Charles Kahn, 'Payment Systems and Privacy', in Federal Reserve Bank of St. Louis Review, Vol. 100, No. 4 (Fourth Quarter 2018), p. 337-344. https://doi. org/10.20955/r.100.337-44

John Kiff et al., 'A Survey of Research on Retail Central Bank Digital Currency', in IMF Working Papers, No. 20/104 (2020), https://www.imf.org/en/Publications/WP/Issues/2020/06/26/ A-Survey-of-Research-on-Retail-Central-Bank-Digital-Currency-49517

Alexander Kriwoluzky and Chi Hyun Kim, 'Public or Private? The Future of Money', in Monetary Dialogue Papers, December 2019, https://doi.org/ $10.2861 / 880099$

Christine Lagarde, 'Winds of Change. The Case for New Digital Currency', in IMF Speeches, January 2019, http://dx.doi.org/10.5089/9781484389171.076

Steven Levy and Gregory Barber, 'The Ambitious Plan Behind Facebook's Cryptocurrency, Libra, in Wired, 18 June 2019, https://www.wired.com/ story/ambitious-plan-behind-facebooks-cryptocurrency-libra

Morten Linnemann Bech and Rodney Garratt, 'Central Bank Cryptocurrencies', in BIS Quarterly Review, September 2017, p. 55-70, https://www.bis.org/ publ/qtrpdf/r_qt1709f.htm

Heike Mai, 'Cash Empowers the Individual Through Data Protection', in Talking Point, 2 July 2019, https://www.dbresearch.com/PROD/RPS_EN-PROD/ PROD0000000000495958/Cash_empowers_the_individual_through_data_ protecti.xhtml

John Miedema et al., 'Designing a CBDC for Universal Access', in Bank of Canada Staff Analytical Notes, No. 2020-10 (June 2020), https://www. bankofcanada.ca/?p=212517

Sridhar Ramaswamy, 'Powering Ads and Analytics Innovations with Machine Learning, in Google Blog, 23 May 2017, https://blog.google/products/marketingplatform/360/ powering-ads-analytics-innovations-with-machine-learning-xp

REPRESENT project, Secret Surveillance Scoring: Urgent Request for Investigation and Enforcement Action, 24 June 2019, https://www.representconsumers.org/ wp-content/uploads/2019/06/2019.06.24-FTC-Letter-Surveillance-Scores.pdf

Felix Salmon, 'Why Payments Won't Ever Be Anonymous', in Reuters, 16 December 2011, http://reut.rs/1pjAtfX 
Maurice E. Stucke, 'Should We Be Concerned About Data-opolies?', in Georgetown Law Technology Review, Vol 2, No. 2 (2018), p. 275-324, https:// wp.me/p8IxBy-zh

Alan F. Westin, Privacy and Freedom, New York, Atheneum, 1967 



\section{Claude Lopez \\ Chapter 9: Digital Currency: A Global Regulatory Framework is Needed}

Digitalization is reshaping society, and monetary systems, commerce and banking are no exception. ${ }^{1}$ So far, the private sector is driving the change: several specialized payment providers in China, Kenya and India offer e-money to specific geographic regions. However, private digital currencies, crypto or stablecoins have yet to make a dent in mainstream payments. ${ }^{2}$

This could change quickly with the deeper involvement of leading card networks, banks and technology giants. Leveraging their existing platform and network could allow these companies to capture a relatively large part of the payment activities. Visa, the world's largest electronic-payment network, has filed a patent application for a 'Digital Fiat Currency'. In contrast, banks such as Signature Bank and Chase have launched digital currencies (token-based Signet and JPMCoin, respectively) that focus on business-to-business payments. Wells Fargo Digital Cash, however, will support cross-border payments. Facebook is moving forward with a less ambitious version of the Libra that focuses on creating a more traditional payment network tied to local currency. ${ }^{3}$

The public sector has also seen significant developments recently. In April 2020, China became the first major economy to pilot a digital currency, while the Bank of England has published the design principles for a similar approach. ${ }^{4}$ Overall, central banks are now expressing a keen interest in the topic and

1 The author would like to thank Oscar Contreras and Benjamin Smith for their assistance and useful discussions on the topic.

2 Some of the specialized payments providers are Alipay and WeChat in China, PayTM in India, and Moffer-Pesa in Kenya. Other private initiatives are cryptocurrencies like bitcoin or stablecoins like Tether, TrustToken's TrueUSD, Circle's USD Coin, DAI, or the Universal Protocol Alliance's UPUSD and UPEUR.

3 Nathaniel Popper and Mike Isaac, 'Facebook-Backed Libra Cryptocurrency Project is Scaled Back', in The New York Times, 16 April 2020, https://www.nytimes.com/2020/ 04/16/technology/facebook-libra-cryptocurrency.html.

4 Bank of England, Central Bank Digital Currency. Opportunities, Challenges and Design, A Discussion Paper, March 2020, https://www.bankofengland.co.uk/paper/2020/ central-bank-digital-currency-opportunities-challenges-and-design-discussion-paper. 
more than 70 per cent are engaged in Central Bank Digital Currency (CBDC) related work. ${ }^{5}$

The multiplication of private digital currencies and the potential for CBDCs emphasize the necessity of a global framework. More specifically, it shows the need of requirements and standards to ensure that all these initiatives lead to an improvement of financial inclusion, security and consumer protection, efficiency in domestic and cross-border payments, and resilience of the payments landscape.

So far, much of the regulatory initiatives are uncoordinated. They are segmented across countries and focus on the extension of existing models to the potential introduction and form of CBDCs, on regulations of private cryptocurrencies, and on the implementation and regulation of various types of fast payment systems. Most ignore that, ultimately, the new innovative money instruments may not fit within the existing regulation and legacy systems. Indeed, technological innovation challenges current practices and existing legal and regulatory jurisdictions, either geographic or sectoral.

To avoid unnecessary regulatory and monitoring burdens, as well as regulatory arbitrage, an international network of regulators, such as the G20, needs to play a more decisive role in shaping these developments, from the innovation to the regulation. This would also ensure they contribute to global economic growth and financial inclusion.

This chapter lays out a few elements that must be part of the discussion when designing the global oversight framework for a digitalized financial world to ensure the outcome is a pertinent, inclusive and adaptable system of standards, rules, practices and regulations. So far, most of them have received less attention than more technical issues such as personal privacy, the architecture of a digital currency system or their potential impact on the financial system.

First, the chapter highlights two necessary requirements in the design of digital currencies that are essential to their success as well as to their contribution to economic growth and financial inclusion: transparency and interoperability. Then, it discusses the oversight framework that will support the global implementation of these and other requirements, and facilitate the emergence of a less fragmented approach to the global digital regulation of finance. More specifically, it identifies trade-offs among global regulatory issues encountered when

5 Codruta Boar, Henry Holden and Amber Wadsworth, 'Impending Arrival - a Sequel to the Survey on Central Bank Digital Currency', in BIS Papers, No. 107 (January 2020), https://www.bis.org/publ/bppdf/bispap107.htm. 
focusing on capital access, market structure and consumer experience. It shows that developed and less developed countries tend to have different sets of regulatory priorities and propose a road map to bridge these gaps when discussing global policies.

\subsection{Requirements: interoperability and transparency}

The digitalization of the financial world will support public policy goals such as financial inclusion and enhanced effectiveness of cross-border transfers if it creates a digital ecosystem that is trustworthy, convenient, easy to use, accessible, fast and affordable. For a digital currency, this means it has to demonstrate the integrity of its design and overall architecture (transparency) and it has to work well across different platforms and functions (interoperability).

\section{Transparency}

The creation of Bitcoin in 2008 coincides with a time where the level of trust in governments and banks was low. This attempt to shift the trust from banks and states to algorithms and encryption software did not succeed as much as expected. Yet it provides an excellent illustration of the necessity for a digital currency to convince its users of the integrity of its design and overall architecture. This is true whether the digital currency is from a decentralized or centralized system.

A distributed network, such as Bitcoin, has to synchronize, validate and record token transactions in a replicated database. Such a system includes incentive mechanisms (consensus protocols) to ensure that the group of connected computers agree on the transactions that it is recording. ${ }^{6}$ These consensus protocols are necessary due to the decentralized nature of the cryptocurrency networks: the servers that participate in the network are untrusted.?

A centralized system, such as a CBDC, faces a different problem. Because the set of activities will go beyond the trusted current mechanism, the design and architecture of the CBDC platform need to be known to all to create an appropriate level of integrity and verification in the system. The central bank will have

6 The best-known example in cryptocurrencies is Proof of Work (PoW), which is also known as Bitcoin mining.

7 David K.C. Lee and Ernie G.S. Teo, The New Money: The Utility of Cryptocurrencies and the Need for a New Monetary Policy, 23 May 2020, https://ssrn.com/abstract=3608752. 
to be clear about the various activities and capabilities of each participant in the system. It will have to share the code used to disclose the CBDC functions and the responsibilities and liabilities of key actors. The trust in the CBDC will come from the ability for all stakeholders to assess the computer code, to check if it functions as disclosed, to look for bugs and to test its resilience to hacks. Stakeholders need to trust the code to trust the CBDC.

Transparency is not a new concept in financial services regulation, where transparency and disclosure by regulated entities, and their activities, systems and processes is a core element. The same logic should apply to all digital currencies.

\section{Interoperability}

The digitalization of the economy may lead to a more segmented world as each technological platform may have an incentive to develop a self-sustainable ecosystem. Yet digital currency users who hold an account in a bank or non-bank financial institution should be able to send and receive money from anyone else at low latency and cost. In other words, a digital currency has to be multifunctional and multi-platform.

Unlike physical cash, whose interoperability declines outside of its domestic context, digital money can have excellent interoperability. Credit cards help illustrate some of the expected benefits: they allow users to spend money in different countries (because the credit card company and banks convert to the appropriate fiat currency) and online. In contrast, cash is mostly limited to domestic transactions.

It is highly likely that the future digital world will be a collection of disparate platforms and ecosystems. The success of any digital currency, whether a private or public initiative, will rely on its broad usage across them. Furthermore, and especially for CBDC, interoperability with existing and future systems is critical to ensure its adoption and longevity. ${ }^{8}$ Finally, a digital currency designed to function on or in conjunction with any platform will have a significant role in commerce: by working almost everywhere, it will create a simple store of value, and will facilitate fast, efficient and immediate payments.

8 Markus K. Brunnermeier, Harold James and Jean-Pierre Landau, 'The Digitalization of Money', in NBER Working Papers, No. 26300 (September 2019), https://scholar. princeton.edu/markus/node/154836. 


\subsection{Elements for an inclusive and adaptable global framework}

Requirements for the design of a digital currency need to be standardized and implemented across the world as there will be more than one digital currency. A global regulatory framework is a necessary complement to ensure global standards in the design and their implementation. Furthermore, this internationally coordinated effort is the only solution to deal with the disconnect between geographic regulatory jurisdictions and coverage of the digital platforms that expand beyond countries' borders. ${ }^{9}$ Added to that, the increasing cross-border use of digital currencies, the growing presence of non-financial companies providing financial services and the fast pace of these changes will very soon make the current regulatory and monitoring framework used to assess financial stability obsolete.

The new framework should include concepts such as governance for data usage and exchange. The network of relevant authorities needs to grow beyond financial regulators to include technology-related ones. Finally, the standardized regulations, rules and practices need to consider how digitalization impacts countries differently.

The level of development, needs and concerns of the country drives its regulatory focus, leading to a segmented landscape of initiatives dealing with technological change in finance. There is a clear delineation between developed and less-developed countries; in terms of issues related to capital access, between financial inclusion and financial stability; in terms of issues related to market structure, between market efficiency and antitrust; and in terms issues related to consumer experience, between consumer welfare and data usage..$^{10}$

\section{Capital access: financial inclusion and financial stability}

MercadoLibre in Latin America, Alipay, and WeChat in China, and M-Pesa in Kenya and India are often used to illustrate how tech firms' involvement in financial services helps financial inclusion. ${ }^{11}$ Large tech companies rely on their abilities to pool, process and use pertinent information to provide financial services

9 Ibid.

10 Claude Lopez and Benjamin Smith, It's Bigger than Big Tech: A Framework to Understand the Economy of Tomorrow, Milken Institute, 2020, forthcoming.

11 Bank for International Settlements (BIS), 'Big Tech in Finance: Opportunities and Risks', in Annual Economic Report 2019, June 2019, p. 55-79, https://www.bis.org/publ/ arpdf/ar2019e3.htm; Dennis Ferenzy, A New Kind of Conglomerate: BigTech in China, Institute of International Finance (IIF), November 2018, https://www.iif.com/Portals/ 0/Files/chinese_digital_nov_1.pdf; Tobias Adrian and Tommaso Mancini Griffoli, 'The 
to the untapped population. Consumers can use smartphones and free internet access to open bank accounts, pay for goods electronically and apply for loans.

In contrast, in the United States, strategic partnerships between large tech companies and incumbent financial institutions raise concerns regarding financial stability. The tech company can provide a third-party service to a financial institution, such as Capital One using Amazon Web Services, or offer a financial service through its digital platforms with a financial institution managing the back-end delivery, such as the Apple Card resulting from the partnership between Apple and Goldman Sachs. In both cases, a single disruption to the tech company could have downstream effects on the financial institutions, magnifying the risk to the broader financial ecosystem. ${ }^{12}$

Similarly, most international institutions focus on the potential risk these companies may represent to financial stability. These companies dominate the provision of some financial services and the lack of alternative, if they were to fail, is a concern: a sudden loss in consumer trust for Alibaba could lead to a mass exodus of deposits, with the potential to disrupt the entire interbank funding system in China. Alibaba owns one of the world's largest money market funds. ${ }^{13}$

\section{Market structure: market efficiency and antitrust}

A country's needs in infrastructure - physical and digital - drive the effects of tech companies on its market structures and regulatory focus.

Emerging and developed economies' regulators and international organizations have praised the efficiencies brought by tech companies to domestic markets, from developing the necessary infrastructure to lower costs, improved quality of goods and services and increased amount of capital investment in research and development. ${ }^{14}$

In contrast, antitrust regulators in developed economies focus on the lack of competition inherent with the dominant position of large companies in some markets. Their ability to invest large amounts of capital into new technologies

Rise of Digital Money', in FinTech Notes, No. 19/01 (July 2019), https://www.imf.org/ en/Publications/fintech-notes/Issues/2019/07/12/The-Rise-of-Digital-Money-47097.

12 Financial Stability Board (FSB), BigTech in Finance. Market Developments and Potential Financial Stability Implications, 9 December 2019, https://www.fsb.org/?p=19398.

13 Ibid.; Dennis Ferenzy, A New Kind of Conglomerate: BigTech in China, cit.

14 In China, Alibaba was essential in the expansion of the freight and logistics infrastructure to rural areas, a necessary step to gain access to their mostly untapped consumer base. 
such as artificial intelligence and machine learning allows them to increase their offering of products and services while controlling the associated costs. ${ }^{15}$ While acknowledging the efficiency gains, European officials have raised concerns derived from this dominant position, such as killer acquisitions, limitation of consumer freedom and manipulations of the consumer decision-making process.

\section{Consumer experience: consumer welfare and data usage}

The contribution of technology to both capital access and market structure relies on the ability to access and process data collected from the customer.

The benefits are unquestionable. Technology is the main contributing factor in the lowering of the remittance system's cost and the increasing speed of transactions. ${ }^{16}$ The use of artificial intelligence and machine learning helps identify fraud and other criminal activities. ${ }^{17}$

But tech companies' usage and management of consumer data have been a concern for regulators, mainly from Europe and the United States. The issues raised range from digital authoritarianism and the spread of misinformation to systematic bias in the financial services sector, data privacy and data ownership rights. ${ }^{18}$

Data access, usage and management are at the core of the technological innovation that improves access to services - financial and others. This is especially the case for underserved populations, often located in less developed countries. Yet Europe drives most of the regulatory efforts related to data protection, dictating the terms of the regulatory framework based on its priorities.

15 Luigi Zingales and Filippo Maria Lancieri, Stigler Committee on Digital Platforms. Policy Brief, September 2019, https://www.chicagobooth.edu/research/stigler/newsand-media/committee-on-digital-platforms-final-report; Digital Competition Expert Panel, Unlocking Digital Competition, London, HM Treasury, March 2019, https:// www.gov.uk/government/publications/unlocking-digital-competition-reportof-the-digital-competition-expert-panel.

16 In Asia, Alibaba's subsidiary Ant Financial provides remittance services that are cheaper and quicker than the ones offered by financial institutions. BIS, 'Big Tech in Finance: Opportunities and Risks', cit.

17 Dennis Ferenzy, A New Kind of Conglomerate: BigTech in China, cit.

18 Ibid.; Luigi Zingales and Filippo Maria Lancieri, Stigler Committee on Digital Platforms. Policy Brief, cit.; Kathryn Petralia et al., 'Banking Disrupted? Financial Intermediation in an Era of Transformational Technology', in Geneva Reports on the World Economy, No. 22 (2019), https://voxeu.org/node/64605. 
Unchallenged, these standards will become global and could adversely impact economic growth in other countries with different needs and challenges.

\section{Conclusion}

The digitalization of the economy will not lead to one global and unique system but to several platforms. A successful digital currency would have to function in most of them. Yet these platforms will expand beyond countries' regulatory and monitoring jurisdictions, emphasizing the need for a new global oversight framework.

Interoperability and transparency are essential requirements to ensure that technology leads to financial inclusion as well as cost reduction and speed increase for cross-border transfers. They will also provide a level of competition that will continue to encourage the fast pace of innovation.

They need to be complemented by a global coordinated effort to implement these requirements as well as to design a set of rules, regulations and best practices that will ensure the good functioning and monitoring of the financial system.

This chapter suggests reorganizing financial regulatory discussion related to the creation of this oversight framework around three dimensions: capital access for financial integration and financial stability, market structure for market efficiency and antitrust, and consumer experience for consumer welfare and data usage. This classification of the regulatory concerns allows us to understand how they are related to each other and why different countries prioritize them differently. A country may prioritize financial inclusion over financial stability, depending on its level of development, but that may change with the evolution of its economy. Similarly, underserved communities, individuals or companies in developed countries will benefit from a more nuanced approach to financial regulation.

Digitalization imposes a new way of thinking to fully exploit the benefits of technology. An idea supported by the G30's recommendation: 'the benefits of network effects in payments should be set against the detrimental effects of reliance on dominant private firms. ${ }^{19}$ The goal is to create an inclusive framework that supports inter-jurisdiction coordination and minimizes the risk of regulatory fragmentation.

19 Group of Thirty, Digital Currencies and Stablecoins. Risk, Opportunities, and Challenges Ahead, Washington, July 2020, p. 8, https://group30.org/publications/detail/4761. 
The coordination of international standards will ensure technical interoperability between digital currency infrastructure and payment and banking systems, as well as for cross-border transfers. Digital currencies will force an evolution of the financial services, yet there is a strong potential of complementarity between digital money within the banking system and outside it. ${ }^{20}$ As previously discussed, the success of a digital currency depends on the trust users have in it. So far consumers in Africa and Asia tend to trust telecommunications and social media companies for financial transactions more than regular banks, while in advanced economies, they tend to trust CBDC more than tech or credit card companies.

\section{References}

Tobias Adrian and Tommaso Mancini Griffoli, 'The Rise of Digital Money', in FinTech Notes, No. 19/01 (July 2019), https://www.imf.org/en/Publications/ fintech-notes/Issues/2019/07/12/The-Rise-of-Digital-Money-47097

Bank of England, Central Bank Digital Currency. Opportunities, Challenges and Design, A Discussion Paper, March 2020, https://www.bankofengland.co.uk/ paper/2020/central-bank-digital-currency-opportunities-challenges-anddesign-discussion-paper

Bank for International Settlements (BIS), 'Big Tech in Finance: Opportunities and Risks', in Annual Economic Report 2019, June 2019, p. 55-79, https:// www.bis.org/publ/arpdf/ar2019e3.htm

Codruta Boar, Henry Holden and Amber Wadsworth, 'Impending Arrival - a Sequel to the Survey on Central Bank Digital Currency', in BIS Papers, No. 107 (January 2020), https://www.bis.org/publ/bppdf/bispap107.htm

Markus K. Brunnermeier, Harold James and Jean-Pierre Landau, 'The Digitalization of Money', in NBER Working Papers, No. 26300 (September 2019), https://scholar.princeton.edu/markus/node/154836

Digital Competition Expert Panel, Unlocking Digital Competition, London, HM Treasury, March 2019, https://www.gov.uk/government/publications/ unlocking-digital-competition-report-of-the-digital-competition-expertpanel

Dennis Ferenzy, A New Kind of Conglomerate: BigTech in China, Institute of International Finance (IIF), November 2018, https://www.iif.com/Portals/0/ Files/chinese_digital_nov_1.pdf

20 Tobias Adrian and Tommaso Mancini Griffoli, 'The Rise of Digital Money', cit. 
Financial Stability Board (FSB), BigTech in Finance. Market Developments and Potential Financial Stability Implications, 9 December 2019, https://www.fsb. org/? $\mathrm{p}=19398$

Group of Thirty, Digital Currencies and Stablecoins. Risk, Opportunities, and Challenges Ahead, Washington, July 2020, https:/group30.org/publications/ detail/4761

David K.C. Lee and Ernie G.S. Teo, The New Money: The Utility of Cryptocurrencies and the Need for a New Monetary Policy, 23 May 2020, https://ssrn.com/abstract $=3608752$

Claude Lopez and Benjamin Smith, It's Bigger than Big Tech: A Framework to Understand the Economy of Tomorrow, Milken Institute, 2020, forthcoming

Kathryn Petralia et al., 'Banking Disrupted? Financial Intermediation in an Era of Transformational Technology', in Geneva Reports on the World Economy, No. 22 (2019), https://voxeu.org/node/64605

Nathaniel Popper and Mike Isaac, 'Facebook-Backed Libra Cryptocurrency Project is Scaled Back', in The New York Times, 16 April 2020, https://www. nytimes.com/2020/04/16/technology/facebook-libra-cryptocurrency.html

Luigi Zingales and Filippo Maria Lancieri, Stigler Committee on Digital Platforms. Policy Brief, September 2019, https://www.chicagobooth.edu/research/stigler/ news-and-media/committee-on-digital-platforms-final-report 


\section{Nicola Bilotta and Fabrizio Botti}

\section{Conclusion}

Facebook's project to develop a global stablecoin has been a wake-up call for national and international authorities, driving central banks and international bodies to intensify the research and development phase around central bank digital currencies (CBDCs). When discussing CBDCs, this study refers to a general purpose CBDC that has specific characteristics: (1) it is a central bank liability, so the holder of CBDC would in principle expect that the central bank will redeem the money with cash upon request; (2) it is denominated in an existing unit of account, in most cases 'pegged' to the fiat currency issued by the central bank; (3) it serves as a medium of exchange and a store of value, which could be remunerated; and (4) it is in principle exchangeable at par with no exchange fees, although, there could be transaction or service fees claimed by the central bank or the service providers.

CBDCs are likely to be introduced in the near future. From being a theoretical concept, CBDCs seem to have rapidly become an inevitable innovation. More than 80 per cent of central banks surveyed by the Bank for International Settlements (BIS) declared that they are engaging in CBDC projects and some of them have already started pilot experiments. ${ }^{2}$ Countries are carefully evaluating the implementation of CBDCs because this innovation, in addition to important benefits, can also lead to remarkable risks and challenges. In order to assess the risks and benefits of a CBDC in a given country, central banks need to acknowledge the differences across business sectors, in the stages of development and socio-economic contexts, which all play key roles in driving the success or the failure of specific payment and financial market models. CBDCs present an opportunity to develop a more secure and efficient financial system than the current one by reshaping the underlying technology. The underlying technology of a CBDC system will be the foundation that will define how the rest of the financial market will work from a technical perspective. This innovation, however, also raises a set of legal concerns. Depending on the design that such a $\mathrm{CBDC}$ will take, the current laws and regulations could require some degree of

1 Conclusion has been developed and shared upon by all the authors of the volume.

2 Raphael Auer, Giulio Cornelli and Jon Frost, 'Taking Stock: Ongoing Retail CBDC Projects', in BIS Quarterly Review, March 2020, p. 97-98, https://www.bis.org/publ/ qtrpdf/r_qt2003z.htm. 
adjustment to properly frame this kind of transaction - in relation to the legal implications on legal tender and consumer protection, for example.

Considering the relevant factors involved, countries should decide, according to their own specific requirements, which unique balance of design and relative implications could help to meet their goals. CBDCs could greatly improve the existing domestic and global payment and financial systems but also have far reaching implications. Their effects may blur the boundaries of the structure of financial markets, giving rise to major macroeconomic and political impacts.

CBDCs could lower transaction costs while improving the speed of transactions, ultimately enhancing the efficiency of a domestic payment system. CBDCs could also potentially help in decreasing the high transaction costs associated with cross-border payments and international remittances. Furthermore, CBDCs could promote greater financial inclusion, establishing a more inclusive banking system with cheaper and easier access to financial services while helping the creation of basic financial identity. Today, more than 1.7 billion people lack access to a bank account. ${ }^{3}$ CBDCs could also promote widespread interoperability, linking incumbent financial institutions, fintech industry and mobile money providers with central banks and governments. No central bank has proposed to fully replace physical cash, promoting instead a coexistence between cash and CBCD. However, if implemented incorrectly, CBDCs could exclude social groups for whom cash is the only instrument available, further marginalizing them.

The development of CBDCs could also counterbalance the progressive expansion of cashless payment alternatives provided by private players, which are reducing the demand for cash and ultimately penalizing the use of central bank money. This megatrend could impact on the effectiveness of monetary policy and have implications for financial stability. CBDCs could then both reduce the market power of large private payment providers and enable the general public to access central bank money even if cash declines.

A CBDC could be an important instrument for central banks to deliver their public policy objectives. A remunerated digital currency could also be a powerful tool to improve the transmission mechanism of monetary policy. Interest rate changes would immediately be transferred to account balances and, in time of crisis, it would become easier to break the 'zero lower bound' constraints and

3 Asli Demirgüç-Kunt et al., The Global Findex Database 2017. Measuring Financial Inclusion and the Fintech Revolution, Washington, World Bank, 2018, p. 4-5, https:// globalfindex.worldbank.org. 
facilitate helicopter money. However, CBDC systems could challenge the technical capacity of central banks, even when a significant portion of these operations is outsourced, increasing operational and reputational risks.

Yet, depending on the interest rate policy design, CBDCs could compete with commercial bank deposits, increasing the risks of systemic instability. There is a risk of progressively eroding margins and increasing the cost of bank funding, which could lead, eventually, to higher rates on loans. Moreover, in extreme situations, there could be a risk that CBDCs would ease a running out of bank deposits into CBDC. The degree of the private banking industry's crowding out and its effects depend, however, on the design of a CBDC. Some of the current pilot experiments and proposed models in theory involve a two-layer architecture. This would imply that there is a basic functional layer of the CBDC itself on which a second layer is built, managed by private financial institutions that interface with consumers. Other experiments, instead, promote a token-based and one-tier system $\mathrm{CBDC}$, meaning that central banks would directly distribute a CBDC accessible to everyone.

A key issue will be the degree of privacy and anonymity that a CBDC system can and should incorporate. The shift from physical cash to CBDCs will alter the current information asymmetry between governments and individuals. On the one hand, CBDCs could improve the efficiency of rules aimed at AML and tax evasion. Moreover, central banks are not profit-driven, they do not monetize the data they gather, as private corporations could potentially do through the introduction of private digital currencies. On the other hand, CBDCs could provide public authorities with a concentration of personal information which could lead to abuses and, with autocratic governments, to the limitation of personal freedoms. CBDCs could be technically designed to blind or regulate regulators' visibility into CBDC transactions.

CBDCs also have the potential to challenge the dominant role of the US dollar in international transactions. However, if China does not move forward in the direction of a more transparent and open financial market, a digital renminbi may not gain significant international attraction. Similarly, if the EU does not complete a capital market union, a banking union and further reforms to improve the governance of the monetary union, a digital euro is not likely to have the firepower to compete with the US dollar. Moreover, it will be interesting to observe if regional digital currencies (for example, the South African rand, the Brazilian real, the Saudi Arabia riyal or the Russian ruble) could take traction and substitute international reserve currencies in certain transactions.

In view of the technical, regulatory, economic and political challenges and implications, the introduction of CBDCs cannot be rushed. CBDCs are part of 
a wider transformation of the financial sector, driven by the digitalization of our society. For CBDCs, a more coordinated international effort is required to set standards, rules, practices and regulations to develop a common framework to maximize the benefits of CBDCs and minimize the risks. In this phase of intense evaluation and research on CBDCs, international cooperation is key. And so, in order to adopt a broad and inclusive perspective, the current discussion on the development of CBDCs must include stakeholders other than financial and international regulators - such as technological companies and civil society.

The challenge, in short, is to ensure that the introduction of CBDC will help to improve the global economy and achieve a more inclusive society.

\section{References}

Raphael Auer, Giulio Cornelli and Jon Frost, 'Taking Stock: Ongoing Retail CBDC Projects', in BIS Quarterly Review, March 2020, https://www.bis.org/ $\mathrm{publ} / \mathrm{qtrpdf} / \mathrm{r} \_\mathrm{qt} 2003 \mathrm{z} . \mathrm{htm}$

Asli Demirgüç-Kunt et al., The Global Findex Database 2017. Measuring Financial Inclusion and the Fintech Revolution, Washington, World Bank, 2018, https://globalfindex.worldbank.org 


\section{Contributors}

Robleh Ali is a founder of Wadagso, a specialist company offering software engineering and public policy expertise to design, build and performance test central bank digital currency (CBDC) and associated next generation financial market infrastructure. The goal is to use technology to create a new financial system which is more secure, efficient and equitable. Before starting Wadagso, Robleh led the CBDC research at MIT and the Bank of England.

Nicola Bilotta is Researcher at the Istituto Affari Internazionali (IAI) in the international political economy area. Previously, he worked as a Senior research analyst at The Banker Research Team (Financial Times), with which he still collaborates. He was associate fellow at the Seven Pillar Institute of Finance $\&$ Ethics and associate researcher at the Istituto di Alti Studi di Geopolitica e Scienze Ausiliari.

Fabrizio Botti is Senior Fellow in the field of economics and finance at Istituto Affari Internazionali (IAI) and Intesa Sanpaolo Fellow. He is also Research Fellow at Guglielmo Marconi University. He is core member of 'Minerva Laboratory on Gender Diversity and Gender Inequality' at the Department of Statistics of Sapienza University of Rome. Previously he was Marie Curie Fellow at the Faculty of Economics and Politics of University of Cambridge.

Massimo Cirasino is the founder and CEO of the Payment Systems Academy and a global advisor on payment and settlement system matters. Prior to that, he has been leading the payments and financial infrastructures practice at the World Bank from 1998 to 2017. He also led and participated in several working groups and task forces sponsored by the World Bank itself, the Committee on Payments and Settlement Systems (CPMI) and the International Organization of Securities Commissions (IOSCO).

Claude Lopez is the Head of the Research Department at Milken Institute, where she leads data-driven efforts aimed at influencing global policy issues on International Finance, Health Economics, and Regional Economics. She is an active member of the T20 task force on international financial architecture. Before joining the Milken Institute, Lopez headed multiple research teams at the Banque de France, and was professor of Economics at the University of Cincinnati. 
Jan Knoerich is Senior Lecturer in the Economy of China at the Lau China Institute in King's College London's School of Global Affairs. His research examines the business, political economy and development dimensions of China's financial internationalisation. His work on Renminbi internationalization has focused on Chinese offshore Renminbi centres and was published in New Political Economy. He is now examining the role of China's digital currency in Renminbi internationalization.

Tim Masela was appointed as Head of the National Payment System Department (NPSD) of the South African Reserve Bank in August 2012. He joined the South African Reserve Bank in July 1994 and he represents the Bank on both the Bank for International Settlements (BIS) Committee on Payment and Market Infrastructure and the Continuous Linked Settlement Oversight Committee chaired by the Federal Reserve Bank of New York.

Franco Passacantando is Scientific Advisor at IAI and Senior Fellow at the LUISS School of European Political Economy. At the Bank of Italy he has been Director at the Research Department and Managing Director responsible for monetary operations and payment systems. He has also been Executive Director at the World Bank and Expert Member of the Board of the European Investment Bank. He is currently interim Chairman of Euroclear SA.

Steven L. Schwarcz is a Chaired Distinguished Professor of Law \& Business at Duke University and has been a partner at two of the world's leading law firms. He also has served as a Distinguished Visiting Professor at Oxford and other top universities and has been a senior advisor to, or is a fellow of, numerous international organizations of thought-leading experts in law, finance, and insolvency. 


\section{Abbreviations}

AIIB

AML

API

ATM

BCBS

BCU

BIS

BSN

CBDC

CCP

CFR

CFT

CHIPS

CIPS

$\mathrm{CNH}$

$\mathrm{CNH}$

CPMI

CPSS

CSD

DC/EP

DLT

DvP

ECB

e-Cedi

eCFA

e-Dinar

EFTA

EPC

EU

FATF

FMI

FRB

FSB

G7

GDP

GPS

GPS

HTLC
Asian Infrastructure Investment Bank

Anti Money Laundering

Application Programming Interface

Automated Teller Machine

Basel Committee on Banking Supervision

Banco Central de Uruguay

Bank for International Settlements

Blockchain Service Network

Central Bank Digital Currency

Central Counterparty

Code of Federal Regulations

Combating the Financing of Terrorism

Clearing House Interbank Payments System

Cross-border Interbank Payments System

Offshore Renminbi

Onshore Renminbi

Committee on Payments and Market Infrastructures

Committee on Payment and Settlement Systems

Central Securities Depository

Digital Currency/Electronic Payments

Distributed Ledger Technology

Delivery versus Payment

European Central Bank

Electronic Ghanaian Cedi

Electronic West African CFA franc

Electronic Tunisian Dinar

Electronic Fund Transfer Act

European Payments Council

European Union

Financial Action Task Force

Financial Market Infrastructure

Federal Reserve Bank

Financial Stability Board

Group of Seven

Gross Domestic Product

Global Payments System

Government Payment Programme

Hashed Timelock Contract 


$\begin{array}{ll}\text { IBAN } & \text { International Bank Account Number } \\ \text { IFWG } & \text { Intergovernmental Fintech Working Group } \\ \text { IMF } & \text { International Monetary Fund } \\ \text { IOSCO } & \text { International Organization of Securities Commissions } \\ \text { KYC } & \text { Know-Your-Customer } \\ \text { LTRO } & \text { Long Term Refinancing Operation } \\ \text { NFC } & \text { Near-Field Communication } \\ \text { NPS } & \text { National Payments System } \\ \text { OECD } & \text { Organisation for Economic Co-operation and Development } \\ \text { PAFI } & \text { Payment Aspects of Financial Inclusion } \\ \text { PFMI } & \text { Principles for Financial Market Infrastructure } \\ \text { PK } & \text { Public Key } \\ \text { PboC } & \text { People's Bank of China } \\ \text { PoW } & \text { Proof of Work } \\ \text { PS } & \text { Payments System } \\ \text { PSD2 } & \text { Second Payment System Directive } \\ \text { PSP } & \text { Payment Service Provider } \\ \text { PSSS } & \text { Payment and Settlement Systems and Services } \\ \text { PvP } & \text { Payment versus Payment } \\ \text { QR } & \text { Quick Response } \\ \text { RCBDC } & \text { Retail CBDC } \\ \text { RMB } & \text { Renminbi } \\ \text { RTGS } & \text { Real Time Gross Settlement } \\ \text { RTP } & \text { Real Time Payment } \\ \text { SADC } & \text { Southern African Development Community } \\ \text { SDR } & \text { Special Drawing Right } \\ \text { SIC } & \text { State Information Center } \\ \text { SIPS } & \text { Systemically Important Payment System } \\ \text { SK } & \text { Secret Key } \\ \text { SWIFT } & \text { Society for Worldwide Interbank Financial } \\ & \text { Telecommunication } \\ \text { T2 } & \text { TARGET 2 } \\ \text { T2S } & \text { TARGET 2 Securities } \\ \text { TIPS } & \text { TARGET Instant Payment Settlement } \\ \text { UCC } & \text { Uniform Commercial Code } \\ \text { UNCITRAL } & \text { United Nations Commission on International Trade Law } \\ \text { UPI } & \text { Unified Payment Interface } \\ \text { US } & \text { United States } \\ \text { USC } & \text { United States Code } \\ \text { UTXO } & \text { Unspent Transaction Output } \\ \text { WB } & \text { World Bank } \\ \text { W-CDBC } & \text { Wholesale CBDC } \\ & \end{array}$




\title{
GLOBAL POLITICS AND SECURITY
}

\author{
Series Editor: \\ Prof. Lorenzo Kamel, \\ University of Turin's History Department, \\ and Istituto Affari Internazionali (IAI)
}

"Global Politics and Security" publishes high-quality books authored by leading academics, think-tankers and policymakers on topical questions in international relations and contemporary history, ranging from diplomacy and security, to development, economy, migration, energy and climate. The series publishes works produced by the Istituto Affari Internazionali (IAI), Italy's leading foreign policy think-tank, as well as by authors affiliated to other international think tanks or universities. The aim is to promote deeper knowledge of emerging issues and trends through constant exchange between the worlds of academia and practice. Publications include original monographs and edited volumes which combine a grasp of the past, an understanding of present dynamics, and a vision about potential futures.

Vol. 1 Lorenzo Colantoni, Giuseppe Montesano, Nicolò Sartori (eds): Empowering Africa. Access to power in the African continent

Vol. 2 Aybars Görgülü, Gulsah Dark Kahyaoğlu (eds): The Remaking of the Euro-Mediterranean Vision. Challenging Eurocentrism with Local Perceptions in the Middle East and North Africa.

Vol. 3 Leila Simona Talani, Matilde Rosina (eds): Tidal Waves? The Political Economy of Populism and Migration in Europe.

Vol. 4 Nicola Bilotta, Simone Romano (eds): The Rise of Tech Giants. A Game Changer in Global Finance and Politics.

Vol. 5 Lorenzo Kamel (ed.): The Middle East: Thinking About and Beyond Security and Stability.

Vol. 6 Lorenzo Kamel (ed.): Collapse and Rebirth of Cultural Heritage: The Case of Syria and Iraq.

Vol. 7 Nicola Bilotta and Fabrizio Botti (eds): The (Near) Future of Central Bank Digital Currencies: Risks and Opportunities for the Global Economy and Society.

www.peterlang.com 
